DEPARTMENT OF THE INTERIOR UNITED STATES GEOLOGICAL SURVEY GEORGE OTIS SMITH, DIRECTOR

BUILETIN 4.11

\title{
RESULTS \\ OF
}

\section{SPIRIT LEVELING IN OHIO}

1898 T0 1908, INCLUSIVE

COMPILED BY

S. S. GANNETT AND D. H. BALDWIN

IN COOPERATION WITH THE STATE OF OHJO DURING 1901 TO 1908, INCLUSIVE

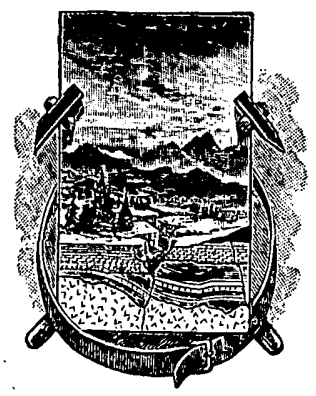

WASH1NGTON

GOVERNMENT: PRIN'IING OFFICE

1909 



\section{CONTENTS.}

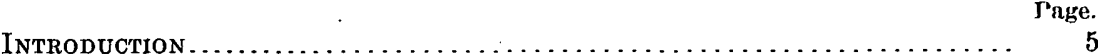

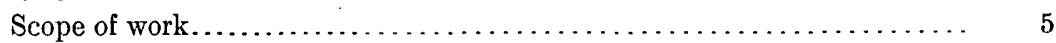

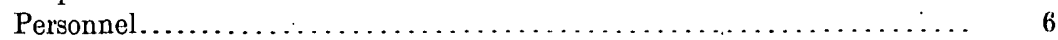

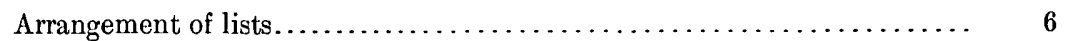

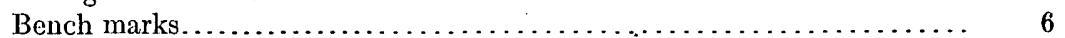

Precise Leveling ............................................... 8

Canton, Cleveland, and Kent quadrangles (Cuyahoga, Stark, and Summit

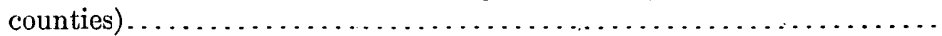

Bowling Green, Continental, Defiance, McClure, Napoleon, and Ottawa quadrangles (Defiance, Henry, Paulding, Putnam, and Wood counties)..

Chillicothe, Otway, Piketon, Scioto, and Waverly quadrangles (Pike,

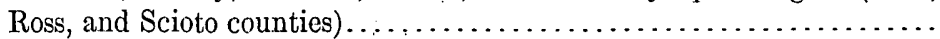

Chillicothe, Circleville, and East Columbus quadrangles (Franklin, Pickaway, and Ross counties)

Cambridge, Cumberland, East Columbus, New Comerstown, Philo, Thornville, Thurston, Uhrichsville, and Zanesville quadrangles.(Fairfield, Franklin, Guernsey, Muskingum, Perry, and Tuscarawas counties)......

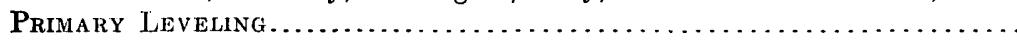

Chardon, Conneaut, and Jefferson quadrangles (Ashtabula and Geauga counties)...

Akron, Ashtabula, Berea, Cleveland, Euclid, Kent, Mentor, Oberlin, and Perry quadrangles (Astabula, Cuyahoga, Geauga, Lake, Lorain, Portage,

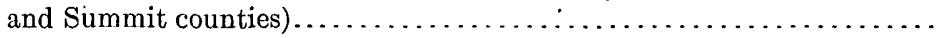

Andover, Bristolville, Chagrin Falls, Garrettsville, and Kinsman quadrangles (Ashtabula, Cuyahoga, Geauga, Portage, Summit, and Trumbull

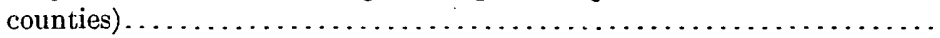

Ravenna, Warren, and Youngstown quadrangles (Mahoning, Portage, and

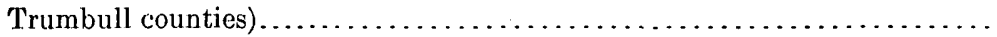
Columbiana and Lisbon quadrangles (Columbiana and Mahoning counties)....

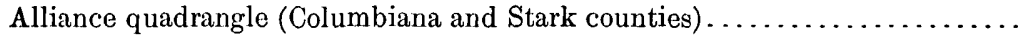
Canal Dover, Canton, Massillon, Navarre, and Wooster quadrangles (Stark, Summit, Tuscarawas, and Wayne counties):

Medina, New London, and Wellington quadrangles (Ashland, Huron, Medina, and Lorain counties)...

Ashland, Mansfield, Perryville, and West Salem quadrangles (Ashland, Rich-

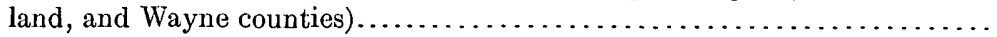

Cadiz, Carrollton, Clarington, Flushing, Salineville, Scio, St. Clairsville, Steubenville, Uhrichsville, Wellsville, and Wheeling quadrangles (Belmont, Carroll, Columbiana, Harrison, Jefferson, and Monroe counties)........... New Martinsville, New Matamoras, St. Marys, and Woodsfield quadrangles (Belmont, Monroe, and Washington counties).

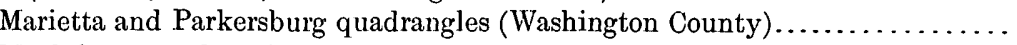
Macksburg quadrangle (Monroe, Noble, and Washington counties)............ Athens and Chesterhill quadrangles (Athens, Morgan, and Washington counties). 
Athalia, Bidwell, Glenwood, and Point Pleasant quadrangles (Athens; Gallia,

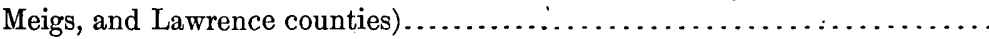

Keno, Pomeroy, Ravenswood, Wilkesville, and Zaleski quadrangles (Athens,

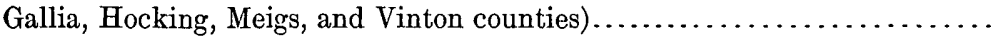

Greenup, Ironton, Jackson, Oakhill, and Scioto quadrangles (Gallia, Jackson, Lawrence, and Scioto counties).

Antrim, Caldwell, Cambridge, Conesville, Coshocton, Cumberland, McConnelsville, New Comerstown, Philo, and Summerfield quadrangles (Coshocton, Guernsey, Monroe, Morgan, Muskingum, Noble, Tuscarawas, and Washington counties)

Circleville, Frazeysburg, Fredericktown, Granville, Lancaster, Logan, Newark, New Lexington, Thornville, Thurston, and Zanesville quadrangles (Athens, Coshocton, Fairfield, Hocking, Knox, Licking, Muskingum, and Perry counties)...

Put in Bay quadrangle (Ottawa County).

Maumee Bay, Oak Harbor, and Toledo quadrangles (Lucas, Ottawa, and Wood

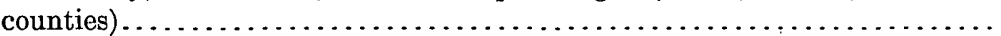

Bellevue, Bowling Green, Elmore, Findlay, Fostoria, Fremont, Sandusky, and Vermilion quadrangles (Erie, Hancock, Huron, Lorain, Sandusky, Seneca,

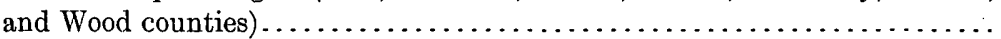

Marion, Sycamore, and Tiffin quadrangles (Crawford, Marion, Seneca, and

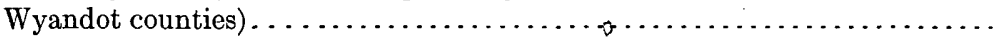

Arlington, Bluffton, and Upper Sandusky quadrangles (Allen, Hancock, Har-

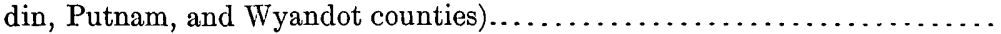

Cardington, Delaware, Dublin, Marysville, Richwood, and Westerville quadrangles (Delaware, Franklin, Madison, Marion, Morrow, and Union counties).

East and West Columbus quadrangles (Fairfield, Franklin, Licking, and Pick-

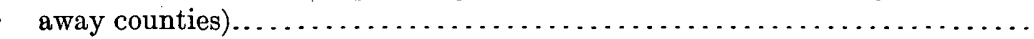

Chillicothe, Laurelville, and Waverly quadrangles (Hocking, Jackson, Pick-

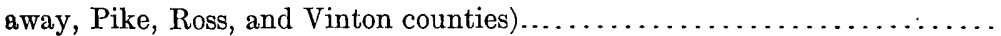

London and South Charleston quadrangles (Clark and Madison counties).....

Continental, Defiance, Delphos, McClure, Napoleon, Ottawa, and Swanton quadrangles (Defiance, Henry, Lucas, Paulding, Putnam, and Wood counties)

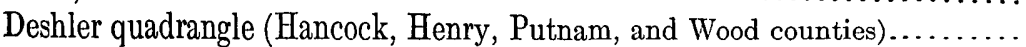

Columbus Grove quadrangle (Allen and Putnam counties).................

Dayton, Era, Jeffersonville, Lima, Mount Sterling, Sidney, Springfield, Troy, and Xenia quadrangles (Allen, Auglaize, Clark, Fayette, Greene, Madison, Miami, and Montgomery counties).

Brookville, Covington, Greenville, Loramie, St. Henry, West Manchester, and Winchester quadrangles (Auglaize, Darke, Mercer, Miami, Montgomery, and Preble counties).

Eaton and Miamisburg quadrangles (Butler, Montgomery, Preble, and Warren counties).

Page.

Blanchester quadrangle (Clinton County) . . . . . . . . . . . . . . . . . .

East Cincinnati, Hamilton, Lebanon, Mason, and West Cincinnati quadrangles (Butler, Hamilton, and Warren counties). 


\title{
RESULTS OF SPIRIT LEVELING IN OHIO FOR THE YEARS 1898 T0 1908, INCLUSIVE.
}

\author{
Compiled by S. S. Gannetr and D. H. Baldwin.
}

\section{INTRODUCTION.}

Scope of work:-The elevations herein given are based on mean sea level. They are determined by precise and primary spirit leveling, adjusted to accord with the adjustment of 1907 by the Coast and Geodetic Survey of the entire net of precise-level lines in the United States. The precise-level net in Ohio is composed of the Coast and Geodetic Survey lines from Belpre west via Cincinnati to the state line, from Toledo south to Cincinnati, from Deshler to Chicago Junction, and from Alliance to Youngstown; the Army Engineers' lines along Ohio and Muskingum rivers; the Baltimore and Ohio Railroad lines from near Lowellville to Chicago Junction and from Warwick to Wheeling; the Pittsburg, Fort Wayne and Chicago Railroad line from East Palestine to Massillon; and lines run by the United States Geological Survey, record of which is given in this bulletin, from Cleveland to Canton, from Ottawa via Roselm and Evansport to Haskins, from Chillicothe to Portsmouth, from Chillicothe to Columbus, and from Columbus to Uhrichsville and Station Fifteen. In the adjustment made by the Coast and Geodetic Survey the weights assigned to the various links of the net were dependent on their length, the method of leveling used, and the comparative results. The recent precise leveling by the Coast and Geodetic Survey, and by the Geological Survey, received the greatest weight and were very little distorted by adjustment, but the railroad lines were considerably altered. The best theoretical value for the junction-point elevations were in most cases not actually adopted, the heights by the 1903 adjustment being allowed to stand where the difference was within the range of uncertainty, thus making less correction to lists already prepared and published. Thus the former elevations on lines from Toledo to Cincinnati, and from Cleveland to Canton, are retained by the Coast and Geodetic 
Survey as the adopted elevations by the 1907 adjustment. The elevations adopted in this bulletin for Uhrichsville and points thence to Massillon, Zanesville, and Wheeling differ also from those adopted by the Coast and Geodetic Survey, the result of an easemerit made to give greater weight to the Baltimore and Ohio Railroad line between Uhrichsville and Wheeling, which was checked by primary circuits of 1908. Descriptions and corrected elevations are given in this bulletin for all standard bench marks previously published for Ohio in Bulletin 185, and in the Appendixes to the Reports of the Director of the United States Geological Survey.

Personnel.-The field work during 1898 to 1902, inclusive, was done under the direction of Messrs. H. M. Wilson and J. H. Renshawe, geographers in charge of eastern and central divisions of topography, respectively, Ohio being then apportioned half to each; that during 1903 to 1906, inclusive, was done under Mr. H. M. Wilson, geographer; that during 1907 was done under Mr. Frank Sutton, geographer; and that during 1908 was done under Mr. W. H. Herron, geographer. The work since January, 1908, was done under the general direction of Mr. R. B. Marshall, chief geographer. Credit is given in the heading of each list to the various levelmen.

The office work of computation and adjustment was principally done by Mr. D. H. Baldwin, topographer, under the immediate supervision of Mr. S. S. Gannett, geographer, and since 1907 under the general direction of Mr. E. M. Douglas, geographer.

Arrangement of lists.- The lists are separated into two classes, precise and primary, distinguishing the degree of refinement in the method of leveling employed, and each list is subdivided so that the results for each quadrangle are combined. The elevations under precise leveling were determined by lines run either in both forward and backward directions or by simultaneous double-rodded lines, a highgrade level and rated rods being used and special precautions being taken in observation and reduction to correct error and make the results continuously good; elevations under primary leveling were determined mostly by single lines run with the $Y$ level, precautions being taken against only the principal sources of error and depending upon the closure of circuits for a check. The allowable limit of error observed on the double simultaneous precise line from Cleveland to Canton, by the Geological Survey, is represented in feet by $0.04 \sqrt{\bar{D}}$ and the limit observed on the other precise lines run by the forward and backward method was $0.017 \sqrt{\mathrm{D}}$, in which $\mathrm{D}$ is the distance between bench marks in miles. The limit in feet on primary work is $0.05 \sqrt{\mathrm{D}}$, in which $D$ is the length of circuit in miles.

Bench marks.-The bench marks described in the following lists are of three general forms: First, a circular bronze or aluminum 
tablet $3 \frac{1}{2}$ inches in diameter and one-fourth inch thick, appropriately lettered, having a 3-inch stem cemented into a drill hole, generally in the vertical walls of public buildings, bridge abutments, or other substantial masonry structures. The second form, employed where masonry or rock is not accessible, consists of a hollow wrought-iron post, 4 feet in length and $3 \frac{1}{2}$ inches in outer diameter, split at the bottom and expanded to 10 inches, so as to prevent both the easy subsidence of the post and the malicious pulling of it out of the ground. These posts are generally sunk 3 feet in the ground, the iron is heavily coated with asphalt, and over the top of the post is riveted a bronze tablet similar to that described above. The third form consists of a copper bolt 1 inch in diameter and 4 inches long, which is split at one end and expanded in a drill hole in masonry by driving on a brass wedge. But few of this class have been used in this State, and their use has now been discontinued.

The numbers stamped upon the bench marks described in these lists represent the elevations to the nearest foot above mean sea level, as determined by unadjusted levels in the field. The notes have been subjected to changes resulting from the adjustments necessary to close circuits and to those resulting from reduction to mean sea level through readjustment of the precise-level net of the United States. Some of the finally accepted elevations as printed herein therefore differ from those submitted as bench-mark numbers by 1 or 2 feet. This method of numbering bench marks has been adopted where many levelmen are working in the same area at the same time as less liable to lead to confusion in identification of bench marks than any attempt at serial numbering, and because the bench-mark number at the same time gives an approximate statement of the elevation. It is assumed that engineers and others finding these bench marks so stamped in the field will communicate with the Director of the United States Geological Survey in order to obtain the accepted elevation to hundredths or thousandths of a foot. Bench marks established under cooperation are stamped with the state name.

For a complete list of standard bench marks in any quadrangle refer to both precise and primary lists. Descriptions of bench marks in adjoining States, but within the border quadrangles herein listed, are not given in this bulletin, neither are the lists of bench marks of other organizations, though the latter furnish a considerable portion of the main control.

Any person finding bench marks in the following lists mutilated or destroyed will confer a favor by notifying the Director, United States Geological Survey, Washington, D. C. 


\section{PRECISE LEVELING.}

\section{. OANTON, CLEVELAND, AND KENT QUADRANGLES.}

CUYAHOGA, STARK, AND SUMMIT COUNTIES.

The elevations in the following list are the result of a line of precise leveling connecting the Lake Survey gage bench mark at Cleveland with bench mark at bridge No. 77 of the Pittsburg, Fort Wayne and Chicago Railroad at Canton. This line and that of the railroad company between Pittsburg, Pa., and Lima, Ohio, were included in the precise-level net adjusted in 1903 by the Coast and Geodetic Survey, and these elevations result from that adjustment, which lowers the original elevation by this line 0.095 foot at Canton with respect to Cleveland. The 1907 adjustment retains these values. The corrections distributed are in proportion to the mileage. The total length of the line is 59.7 miles and the total divergence between the two component lines is 0.076 .

The outfit consisted of a Buff \& Berger precise level, a light umbrella, two double-faced 10-foot nonextensible double-targeted rods, and four steel turning-point pins. On each rod the target on one face was red with a white strip, and on the other black with a white strip, and they were controlled for rapid setting by steel tapes passing over drums at either end and for fine setting by clamp and tangent screw.

The double-simultaneous method was used. By this method two lines are carried along on separate turning points as follows: The rodmen occupy alternate positions, each setting two pins; the notes on one line are taken by the red targets and those on the other line by the black, and recorded on opposite pages of level book. On one line the foresights are always read first, and on the other the backsights first, and the readings on all four faces are completed before backsight pegs are advanced.

The limit of divergence in feet which this line was required not to exceed was set at $0.04 \sqrt{\overline{\mathrm{D}}}$, in which $\mathrm{D}$ represents distance between bench marks in miles.

The leveling was done during part of October and November, 1902, by D. H. Baldwin.

Standard bench marks were recovered in Cleveland and Canton quadrangles and three tablets set by this line in the Kent quadrangle.

CLEVELAND QUADRANGLE.

CLEVELAND, SOUTH ALONG WHEELING AND LAKE ERIE RAILROAD, TO BEDFORD.

Cleveland, south corner of Front and River streets, north corner of Johnson

Block, on corner stone of water table; chiseled cross (U. S. Engineer Corps

bench mark No. 2).

Feet.

Cleveland, zero mark of U.S. Engineer Corps water gage, plane of reference for harbor improvements, and mean elevation of Lake Erie for years 1860

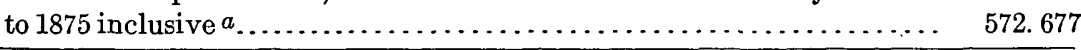

a This elevation was obtained from primary leveling from bench mark No. 2 and is 0.09 foot lower than would be obtained by using the difference by the Lake Survey. 
Cleveland, in front of Erie Railroad station; top of rail.

Cleveland, in front of Erie Railroad station; top of rail.................

Cleveland, in front of Wheeling and Lake Erie Railroad station; top of rail. .

Cleveland, grade crossing of Wheeling and Lake Erie Railroad and Cleve-

land Terminal and Valley Railroad; top of rail...................

Cleveland, east corner of Independence street and East Clark avenue, north corner of railroad bridge over canal and street, on fourth step of wing wall above avenue; chiseled square. . . . . . . . . . . . . . . . . . . .

Newberg, in front of station; top of southwest rail. ..................

Cleveland, grade crossing of Pennsylvania Railroad and Wheeling and Lake Erie Railroad; top of rail.

Cleveland, Miles avenue, crossing near station; top of rail.

Cleveland, Miles avenue, 0.84 mile south of station; northwest corner of girder bridge No. 15 over Akron, Bedford and Cleveland Electric Railroad, on coping stone of foundation; chiseled square..............

Bedford, 2.16 miles northwest of; top of stone milepost " $\mathrm{C} 10$ " (R. R. bench mark)

602. 6

641. 6

587. 35

591. 93

780.7

785. 01

849.2

822. 72

906.50

Bedford, in front of Wheeling and Lake Erie Railroad station; top of rail. .

Bedford, north corner of town hall, face of fourth course of foundation stones from top; chiseled cross.

949. 64

BEDFORD, ALONG PENNSYLVANIA RAILROAD, TO MACEDONIA.

Bedford, in front of Cleveland and Pittsburg station; top of rail.........

Bedford, 1.62 miles south of; grade crossing of the Akron, Bedford and Cleve-

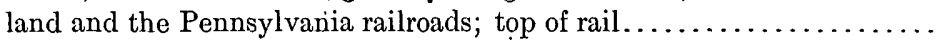

Macedonia, 1.52 miles north of; southwest corner of girder bridge over highway, on coping stone of foundation; chiseled square............ 1, 038. 76

Macedonia, southwest wing wall of girder bridge over road, in top of highest step; bronze tablet stamped "1004 CLEVELAND"................ 1, 003.395

MACEDONIA, WEST ALONG HIGHWA, TO NORTHFIELd.

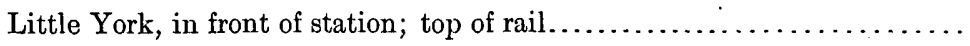

Little York, 350 feet south of station; on north end of arch wall east side of

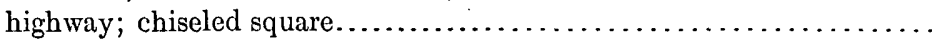

Town Line, in front of station; top of rail...................

Highland Springs, in front of station; top of rail.............. 071.9

\section{KENT QUADRANGLE.}

NORTHFIELD, SOUTH ALONG AKRON, BEDFORd AND CLEVELAND RALLOAD, TO SILVER LAKE JUNCTION.

Chittenden, in front of station; top of rail................... $1,023.8$

Seasons, in front of station; top of rail..................... 1, 011. 1.

Seasons, 0.27 mile south of; southeast corner of girder bridge, on coping stone of parapet wall; aluminum tablet stamped "1002 CI.EVELAND

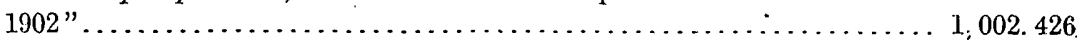

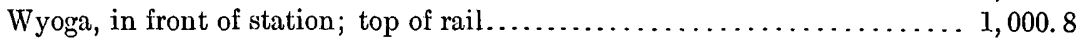

Puttrell, in front of station; top of west rail $\ldots \ldots \ldots \ldots \ldots \ldots \ldots \ldots \ldots .9 . \ldots$

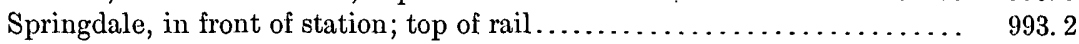

Silver Lake Junction, in front of dispatcher's office; top of rail. . . . . . 1,023. 1

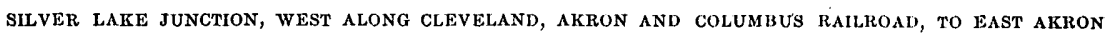
JUNCTION.

Silver Lake Junction, southwest end of large stone-arch bridge over Cuyahoga River, on end of coping stone of west side wall; aluminum tablet

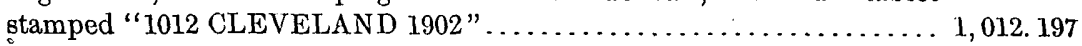

Cuyahoga Falls, in front of station; top of rail................ 011.4 
Cuyahoga Falls, 0.9 mile south of; southwest corner of arch bridge, on Feet. corner of coping stone; chiseled square........................ 1,005. 09

East Akron Junction, northwest corner of stone-arch bridge, over Cleveland Terminal and Valley Railroad, on top stone of wing wall; chiseled square. $\quad 963.73$

EAST AKRON, SOUTH ALONG CLEVELAND TERMINAL AND VALLEY RAILROAD, TO KRUMROY.

East Akron, in front of station; top of rail 981.5

East Akron, 520 feet south of station, north abutment of girder bridge, between tracks, on coping stone; aluminum tablet stamped "983 CLEVE-

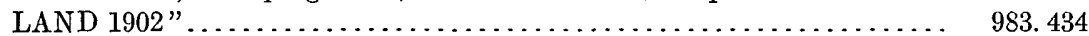

Krumroy, in front of station; top of rail....................... 052.0

CANTON QUADRANGLE.

GRUMROY, SOUTH ALONG CLEVELAND TERMINAL AND VALLEY RAILROAD, TO CANTON.

Myersville, 200 feet northeast of station; on northeast corner of highway bridge, southeast corner of foundation; bronze tablet stamped "1076 CLEVELAND" $1,075.424$

Myersville, in front of station; top of rail..................... $1,073.5$

Aultman (Greentown), in front of station; top of west rail............ 1, 107.9

New Berlin, about 400 feet east of Cleveland Terminal and Valley Railroad highway bridge over Nimisila Creek, northeast corner of west abutment, on coping stone; bronze tablet stamped "1069 CANTON 1901" ........ 1, 067.880 .

New Berlin (Marchand), in front of station; top of rail.............. 1,067.7

New Berlin, 2.08 miles south of, west abutment of bridge No. 44, over brook, on foundation coping stone; chiseled square................ 1,050. 45 Canton, Cleveland Terminal and Valley Railroad station, north side of doorsill to women's waiting room; chiseled square.................. 1,032.03 Canton, in front of station; top of rail.......................... 1,030.4 Canton, bridge 77, on northeast corner of east abutment; chiseled square

(Pittsburg, Fort Wayne and Chicago Railroad bench mark).......... 1,029. 16

BOWLING GREEN, CONTINENTAL, DEFIANCE, McCLURE, NAPOLEON, AND OTTAWA QUADRANGLES.

DEFIANCE, henty, PAULding, PUTNAM, AND WOOD COUNTIES.

The following are the adjusted results of a precise-level line, beginning at bench mark $N_{1}$ at Ottawa and closing on bench mark $B_{1}$ at Haskins, bench marks on the precise-level line of the Coast and Geodetic Survey from Toledo to Cincinnati, the elevations of which are accepted as 729.338 feet and 667.702 feet, respectively, as determined by the 1903 adjustment of precise leveling and retained by the adjustment of 1907. The line runs west from Ottawa along the Cincinnati, Hamilton and Dayton Railway to Roselms, thence north along highways to Ridgeville, thence east to Haskins. The total divergence between direct and reverse lines was 0.042 foot in a total distance of 88.7 miles, and the closure at Haskins was +0.025 foot.

The methods of leveling, type of level, and limit of error are those now used by the Coast and Geodetic Survey: To facilitate computation, nonextensible self-reading rods 3.5 yards in length, graduated to hundredths of a yard, were used, instead of metric rods, and these were read by estimation to thousandths, the sum of three thread readings being a mean reading in feet. 
The line was leveled independently in both forwurd and backward directions, broken by temporary bench marks into sections 0.5 mile to 1.25 miles long, and on all sections upon which the forward and backward measures in feet differed more than $0.017 \sqrt{\mathrm{D}}$ (in which $\mathrm{D}$ is the distance between bench marks in miles) forward and backward measures were repeated until a pair run in opposite directions checked within limits. All other requirements necessary to obtain accurate results were closely adhered to.

The leveling was done in 1906 by C. H. Semper. The party consisted of 5 men-1 levelman, 2 rodmen, 1 umbrella man, and 1 recorder.

OTTAWA QUADRANGLE.

OTTAWA, WEST ALONG CINCINNATI, HAMLLTON AND DAYTON RALWAY, TO' DORNINTON.

Ottawa, on south side of main cross street, about 1.70 feet west of railroad, on large stone step of foundation 5 feet east of cast side of east pillar of a stairway entrance; square lettered "U.S.C. \& G. S. B. M." (bench mark N). .

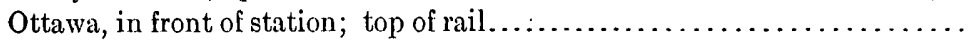

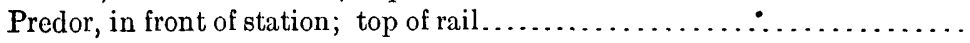

Predor, 1.36 miles west of; northeast corner of foundation of Barney Rosenbaum's farmhouse, aluminum tablet stamped " 733 ".

Feet. 729.338 730.1 735.4

Predor, 4.5 miles west of ; 0.5 mile east of avenue, railroad culvert, on north side of track, aluminum tablet stamped " 726 " ...................

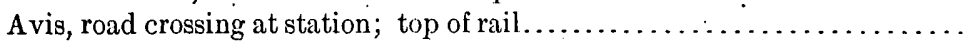

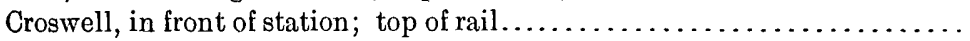
Croswell, 0.5 mile west of, culvert on north side of track, opposite Geo. Bassinger's farmhouse; aluminum tablet stamped " 726 "

Dorninton, grade crossing of Cincinnati, Hamilton and Dayton Railway with Ohio Electric Railroad; top of rail

CONTINEN'TAL QUADRANGLE.

DORNINTON, WEST ALONG CINCINNATI, HAMLLTON AND DAYTON RAILWAY, TO ROSELMS.

Dorninton, 3.62 miles west of, 1 mile east of Cloverdale, bridge over Big Auglaize, west abutment; aluminum tablet stamped " 728 "..........

, Cloverdale, crossing of Toledo, St. Louis and Western Railroad with Cincinnati, Hamilton and Dayton Railway; in front of station..........

East Mandale, in front of station; top of rail........................

Mandale, in front of station; top of rail..........................

Mandale, schoolhouse 150 feet west of canal, north side of railroad, east foundation; aluminum tablet stamped " 723 "....................

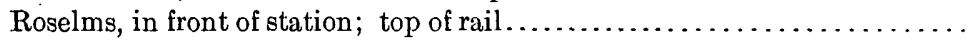

Roselms; on east face of McMillan's grist mill; aluminum tablet stamped "724"

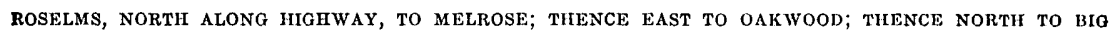
AUGLAIZE RIVER BRIDGE SOUTH OF DEFIANCE.

Roselms, 0.89 mile north of, north abutment of bridge over Middle Creek, top of east side; square marked "U.S. 716 B. M."................

Roselms, 3.06 miles north of, south abutment, west side of stecl highway

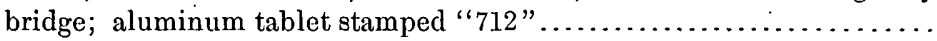

Melrose, north west corner of State and Superior streets, in cement sidewalk; aluminum tablet stamped " 717 ". 
Oakwood, railroad bridge on Main street, in face of east abutment; aluminum tablet stamped " 707 ".

Feet.

Oakwood, 3.88 miles north of, at crossroads, small bridge, north abutment, west face; aluminum tablet stamped " 718 ".

707. 381

Oakwood, 7.87 miles north of, southeast corner of foundation of schoolhouse at crossroads; aluminum tablet stamped " 717 " (?).

718. 336

Oakwood, 10.09 miles north of, Gorman schoolhouse, west face of foundation; aluminum tablet stamped "711".

716. 806

Oakwood, 11.36 miles north of, bridge over Big Auglaize, face of south abutment; square marked "U.S. D B. M. 687 "

686. 74

\section{DEFIANCE QUADRANGLE.}

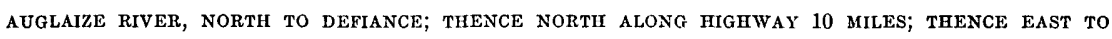
RIDGEVILLE CORNERS; THENCE 2 MILES EAST.

Defiance, county jail, southwest corner; aluminum tablet stamped "Prin. Trav. Sta. No. 8, $692 "$

Defiance, 2.52 miles north of, at crossroads southwest corner of Kelley schoolhouse; aluminum tablet stamped " 713 "...................

Defiance, 5.67 miles north of, southeast corner of schoolhouse at crossroads;

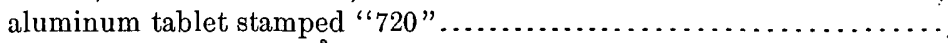

Defiance, 8.64 miles north of, southeast corner of crossroads schoolhouse; aluminum tablet stamped " 714 ".

Evansport, 4.05 miles east of, county-line road, front face foundation of Fred Behrman's house; aluminum tablet stamped " 734 ".

Ridgeville Corners, Hunn Brothers' store, southeast corner water table at front entrance; aluminum tablet stamped " 741 "................

741. 152

\section{NAPOLEON QUADRANGLE.}

NEAR RIDGEVILLE, EAST ALONG HIGHWAY, TO LIBERTY CENTER.

Ridgeville Corners, 2.41 miles east of, crossroads, schoolhouse north side of road, front fence; aluminum tablet stamped " 722 "................

Ridgeville Corners, 4.41 miles east of, front of schoolhouse' No. 5 at crossroads; aluminum tablet stamped " 706 ".

Ridgeville Corners, 7.36 miles east of, at crossroads, west end of north abutment of bridge; aluminum tablet stamped " 682 ".

Liberty Center, 2.4 miles west of, entrance of schoolhouse at crossroads; aluminum tablet stamped " 678 "

706. 030

Liberty Center, crossing of Wabash Railroad west side of town; top of rail..

Liberty Center, front face of townhouse; aluminum tablet stamped " 686 ".

\section{M'CLURE QUADRANGLE.}

LIBERTY CENTER, SOUTHEAST, VIA STONE ROAD, TO GRAND RAPIDS; THENCE EAST TO TONTOGANY.

Liberty Center, 3.42 miles east of, junction of roads to $\mathrm{S}$. \& N. schoolhouse, front face; aluminum tablet stamped " 683 ".....................

Liberty Center, 5.90 miles east of, White's schoolhouse (district 1), north of road, front entrance; aluminum tablet stamped " 674 "

Grand Rapids, bridge over Maumee River, east side of south abutment; aluminum tablet stamped " 655 ".

Grand Rapids, 2.72 miles east of, front entrance of schoolhouse north of road; aluminum tablet stamped " 670 " 
BOWLING GREEN QUADRANGLE.

TONTOGANY, NORTHEAST ALONG CINCINNATI, HAMILTON AND DAYTON RAILWAY, TO HASHINS.

Feet.

Tontogany, in front of station; top of rail.

670.1

Tontogany, 0.34 mile north of, 50 feet north of road crossing, east side of track, top of stone culvert; aluminum tablet stamped "669"

668.803

Haskins, 250 meters west of Cincinnati, Hamilton and Dayton Railway, on Sugar street, water table in south face of public-school building, 4 feet 10 inches above ground, 1 foot 9 inches east of east side of entrance; brass bolt lettered "U. S. C. \& G. S." ............................

667.702

OHILLIOOTHE, OTWAY, PIKETON, SOIOT0, AND WAVERLY QUADRANGLES.

PIKE, ROSS, AND SCIOTO COUNTIES.

The following elevations are the result of a line of precise levels run from Chillicothe south along the Norfolk and Western Railway to Portsmouth, Ohio. The line connects bench mark " $Q$ " of the Coast and Geodetic Survey transcontinental line with a bench mark of the Ohio River survey precise leveling, and, as a result of the 1907 adjustment, the elevation at Portsmouth by this line has been lowered only 0.001 with respect to Chillicothe, but the elevation now accepted at Chillicothe is 0.181 foot less than that formerly computed. The total distance is 49.6 miles.

The method and limit of error used on this line were those adopted by the Coast and Geodetic Survey elsewhere described, but yard rods were substituted for metric, the computation being made in feet. The leveling was done in 1906 by N. A. Campbell and W. H. Monahan in two sections, 21.0 and 28.6 miles, respectively.

CHILLICOTHE, VIA NORFOLK AND WESTERN RAILWAY, TO PORTSMOUTH.

CHILLICOTHE QUADRANGLE.

Chillicothe, in base of pedestal of lamp post on north side of steps of front entrance to court-house; chiseled square (marked B. M. Q, U. S. C. \& G. S. Aug. 5, 1879).

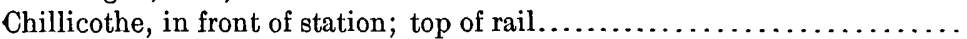

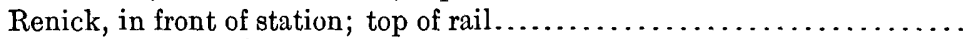

Renick, 1.2 miles south of, north abutment of railroad bridge, west of track, top of retaining wall; aluminum tablet stamped " 624 " ..............

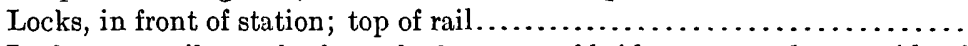

Locks, 0.19 mile south of, north abutmeṇt of bridge over road, west side of track, top of retaining wall; aluminum tablet stamped " 610 ".

Feet. 638. 001

618.4

616.680

6.15. 6

610.030

WAVERLY QUADRANGLE.

Locks, 1.92 miles south of, top of railroad culvert west of track; aluminum tablet stamped " 589 ".

589.213

593.8

Higby, 0.12 mile south of, railroad bridge, west side of track, north abutment, top of retaining wall; aluminum tablet stamped " 589 ".

Higby, 1.03 miles south of, top of railroad culvert, west of track; chiseled square.

588. 732

589.82

Higby, 2.05 miles south of, top of railroad culvert, west of track; chiseled square. 
Omega, in front of station; top of rail.

Feet.

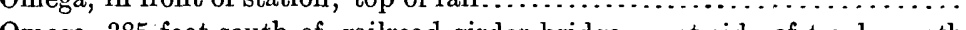
596.8

aba; 385 feet south of, railroad girder bridge, west side of track, north abutment, top of retaining wall; aluminum tablet stamped " 596 ".

595.636

Omega, 1.29 miles south of, north abutment railroad bridge, west of track; chiseled square.

Omega, 2.71 miles south of, north abutment of railroad bridge, east side of

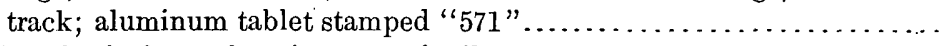

Waverly, in front of station; top of rail.

571.034

Waverly, 0.29 mile south of, north abutment of railroad bridge, on top of retaining wall, east side of track; aluminum tablet stamped " 570 ".....

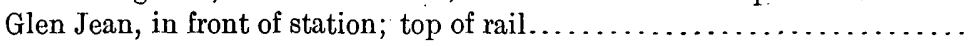

Glen Jean, 0.49 mile south of, south abutment of railroad bridge over river, east side of track, top of retaining wall; chiseled square..............

Glen Jean, 2.73 miles south of, highway bridge over creek, west side of north abutment; aluminum tablet stamped " $562 "$ "....................

\section{PIKETON QUADRANGLE.}

Piketon, in front of station; top of rail.

Piketon, United Brethren Church, northwest corner of foundation; aluminum tablet stamped " 578 ".

571.5

569. 824

573.4

578.716

561.829

Piketon, 2.21 miles south of, west side of bridge over creek, north abutment,

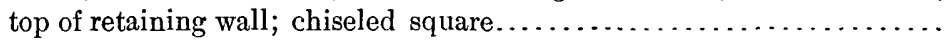

Piketon, 3.83 miles south of, southwest corner of Mrs. Sargent's farm, east side of railroad; primary traverse tablet stamped " 580 "..............

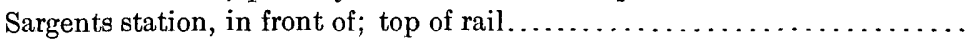

\section{OTWAY QUADRANGLE.}

Sargents, 2.47 miles south of, railroad bridge over creek, on west side of north abutment; aluminum tablet stamped " 551 "..................

Wakefield, in front of station; top of rail.......................

Wakefield, 3.07 miles south of, stone culvert on east side of track, southwest corner of stone abutment; aluminum tablet stamped " 556 ".

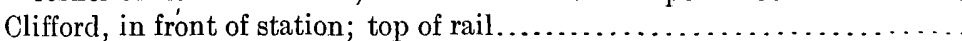

Clifford, 2.04 miles south of, northwest corner of stone culvert, west side of railroad; chiseled square...

Clifford, 3.22 miles south of, northwest corner of railroad bridge over highway, top of abutment; aluminum tablet stamped " 554 "............

SCIOTO QUADRANGLE.

Lucasville, in front of station; top of rail........................

Lucasville, 2.82 miles south of, railroad bridge over road, southeast corner of south abutment; aluminum tablet stamped " $559 " \ldots \ldots \ldots \ldots \ldots . . . . . .$.

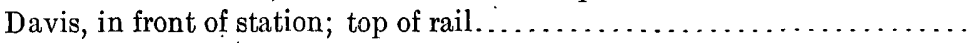

Davis, 1.08 miles south of, bridge over road, south abutment, southwest corner; aluminum tablet stamped " 558 ".......................

Davis, 1.96 miles south of, stone culvert, east side of railroad; chiseled square.

Davis, 4.0 miles south of, stone-arch bridge over creek, top of southwest cor-

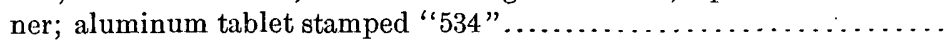

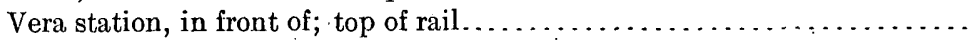

Portsmouth, on southwest corner of stone step, south side of Norfolk and Western Railway station; chiseled square......................

Portsmouth, southeast corner of post-office, in first course of foundation, 1 foot above ground; chiseled square (U. S. Engineer Corps bench mark)..

550.931

555.0

556.079 
CHILLICOTHE, CIRCLEVILLE, AND EAST COLUMBUS QUADRANGLES.

FRANKLIN, PICKAWAY, AND ROSS COUNTIES.

The following are the results of a line of precise levels run from United States Coast and Geodetic Survey bench mark "Q" at Chillicothe along the Norfolk and Western Railway to Columbus. Old bench marks of the double-rodded line of 1899 were recovered and new ones established. As a result of the 1907 adjustment the elevation at Columbus by this line has been increased only 0.001 foot with respect to Chillicothe, the corrections at that place and at Columbus being -0.181 foot and -0.180 foot, respectively, to the unadjusted list based upon the 1903 adjustment elevation at Chillicothe.

The method of leveling, limit of error, and type of level were the same as now used by the Coast and Geodetic Survey. Two self-reading rods were used, 3.2 meters in length, graduated to centimeters and reading by estimation to millimeters; and one large shade umbrella.

The line was leveled independently in both forward and backward directions, broken by temporary bench marks into sections 2 to 3 kilometers long. On all sections upon which the backward and forward measures differed more than $4.0 \mathrm{~mm} . \sqrt{\mathrm{K}}$, in which $\mathrm{K}$ is the distance between adjacent bench marks in kilometers, both the forward and backward measures were repeated until they came within limits, and all the other requirements necessary to obtain accurate results were closely adhered to. The leveling was done in 1905 by E. I. McNair.

\section{CHILLICOTHE TO COLUMBUS.}

CHILLICOTHE QUADRANGLE.

Chillicothe, in wall at side of entrance to court-house; bronze tablet stamped

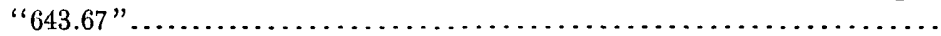

Chillicothe, on pedestal of the lamp-post on north side of steps of front entrance of court-house; marked "Q B-M U. S. C.\& G. S. Aug. 5, 1879 ".

Chillicothe, crossing of Baltimore and Ohio Railroad and Norfolk and

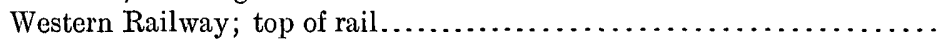

Chillicothe, 0.5 mile north of, in top of south abutment of Norfolk and Western Railway bridge on west side, 12 feet from center of track and 5.75 feet below top of rail; aluminum tablet. . . . . . . . . . . . . . . . . . . . .

Chillicothe, 5.6 miles north of, 90 feet south of Delano station, at southeast corner of crossroads, in bridge seat stone; bronze tablet stamped " 691 COLUMBUS 1899".

Feet. 643. 195

638.001

626.7

620. 307

690. 752

Chillicothe, 5.6 miles north of, in top of concrete bridge over small stream at Delano station, Scioto Valley Electric Railroad, at southeast corner of crossroads; aluminum tablet. ...........................

Delano station, Norfolk and Western Railway; top of rail.............

Kinnikinnick station, Norfolk and Western Railway; top of rail.........

Kingston, 1,000 feet north of, in top of stepstone of arch culvert, southwest corner; bronze tablet stamped "774 COLUMBUS 1899." (On spur line 0.46 mile).
693.952

694.4

710. 3 
Kingston, Norfolk and Western Railway station; top of rail..............

Kingston, 0.75 mile north of, in top of southwest corner of a stone-arch bridge across a branch on Norfolk and Western Railway; aluminum

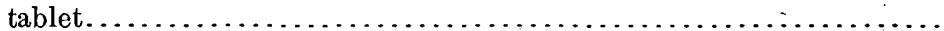

Elmwood flag station; top of rail.

Feet.

765.2

746.711

744. 2

\section{CIRCLEVILLE QUADRANĠLE.}

Haysville, 0.75 mile south of, in west end of top of coping stone of arch culvert across a small draw on Norfolk and Western Railway; aluminum

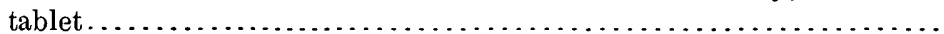

Circleville, 4 miles south of, in north end of west abutment of covered bridge over Sippo Creek; bronze tablet stamped "707 COLUMBUS 1899."

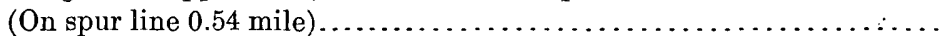
Circleville, 1.62 miles south of, in east side of south end of top of a stone culvert on the Norfolk and Western Railway at south end of siding at Gregg

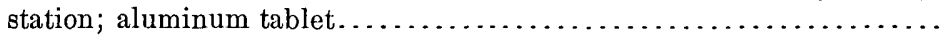

Circleville, Norfolk and Western Railway station; top of rail...........

Circleville, at northwest corner of main building of court-house; iron post stamped "Prim. Trav. Sta. No. 4." (On spur line 0.25 mile) .........

Circleville, 2 miles north of, in south end of west parapet wall of box culvert; aluminum tablet stamped "693 COLUMBUS 1899" (interpolated

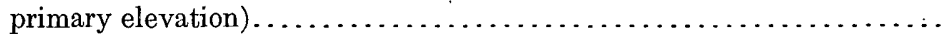

Circleville, 4 miles north of, 60 feet south of viaduct across Scioto Valley Electric Railroad and Norfolk and Western Railway, about 500 feet north of elevator at siding, 12 feet west of center of track of Norfolk and Western

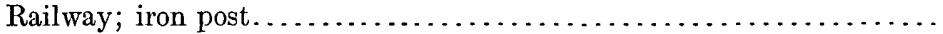

Crowley, 0.25 mile south of, 2 miles south of Asheville, in cover stone on east side of a small stone culvert on Norfolk and Western Railway; alumi-

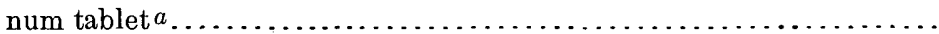

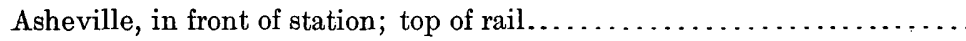

\section{EAST COLUMBUS QUADRANGLE.}

Duvall, in top of west side and center of the capstone of a small stone culvert on the Norfolk and Western Railway, about 30 feet southwest of road crossing and 90 feet south of station; aluminum tablet...............

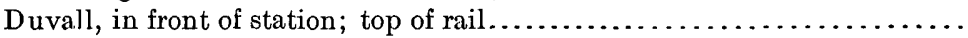

Duvall, 0.75 mile north of, in top and east side of small stone culvert on Norfolk and Western Railway, at milepost C 18; aluminum tablet......

Lockbourne, in top of south pier, west end of Norfolk and Western Railway bridge over Ohio Canal; aluminum tablet stamped "716 COLUMBUS $1899 "$.

Lockbourne, in front of station; top of rail .......................

Miner, in front of station; top of rail

Rees, 0.33 mile south of, in west end of bridge seat of north pier of Norfolk and Western Railway bridge across Walnut River, 10 feet from center of track and 4 feet below top of rail; aluminum tablet.................

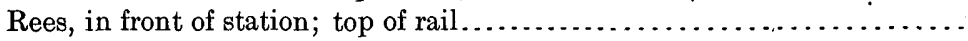

Valley Crossing, 1 mile south of, in east end of bridge seat of north abutment of plate girder viaduct Norfolk and Western Railway across Scioto Valley Electric Railroad; aluminum tablet.......................

712.098 
Valley Crossing, Norfolk and Western and Hocking Valley Railway cross-

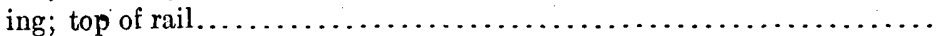

Bannon, Norfolk and Western and Toledo and Ohio Central Railway cross-

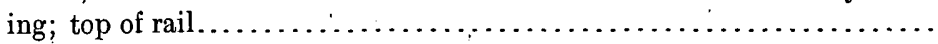

Columbus, crossing of Broad street and Norfolk and Western Railway; top

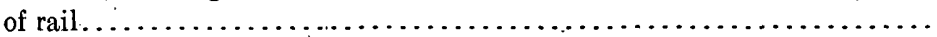

Columbus, city bench mark on water table at northeast corner of state eapitol (city datum elevation 780.630)

Feet.

773.4

774. 8

768. 6

780.400

Columbus, in northwest corner of court-house, below corner stone; aluminum tablet stamped " 778 COLUMBUS $1899 " \ldots \ldots \ldots \ldots \ldots \ldots \ldots$.

CAMBRIDGE, OUMBERLAND, EAST COLUMBUS, NEW COMERSTOWN, PHIL0, THORNVILLE, THURSTON, UHRICHSVILLE, AND ZANESVILLE QUADRANGLES.

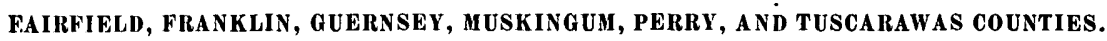

The following are the results of a line of precise leveling from Valley Crossing, near Columbus, to Uhrichsville and Station Fifteen post-office. The line extends from a bench mark on the precise line from Chillicothe to Columbus, and checks at Uhrichsville upon bench mark 48 on the Baltimore and Ohio Railroad precise line from Warwick to Wheeling, a connection also having been made to levels of the Muskingum River Survey of the U.S. Fingineer Corps at Zanesville. The introduction of these lines into the precise-level net in the 1907 adjustment had resulted in changing the unadjusted elevations by this line with respect to Chillicothe, +0.001 foot at Columbus, +0.002 foot at Zanesville, and -0.005 foot at Uhrichsville, all in addition to the constant correction of -0.181 foot to the 1903 adjustment at Chillicothe. In preparing this list, however, the correction found thus for bench mark 48 at Uhrichsville has not been accepted, because primary levelings of 1908 and prior years show that greater weight should have been given the Baltimore and Ohio precise levels between this point and Wheeling, and as an easement the adjustment placed in that line has been reduced to 0.632 foot by accepting the Baltimore and Ohio line unadjusted from Massillon based upon the 1907 adjustment value there. The corrections then given to the original elevations by the line here listed are as above stated, except that between Zanesville and Uhrichsville the corrections vary between -0.179 and -0.432 foot, an adjustment of 0.253 foot.

The method and limit of error used on this line are those adopted by the Coast and Geodetic Survey elsewhere described, but yard rods were substituted for metric, the computations being made in feet.

The leveling was done in 1906 by W. H. Monahan. 9639-Bull. 411-09-2 


\section{EAST COLUMBUS QUADRANGLE.}

VALLEY CROSSING, NORTH ALONG NORFOLK AND WESTERN RAILWAY, TO BANNON; THENCE SOUTHEAST ALONG TOLEDO AND OHO CENTRAL RAILWAY, TO PICKERINGTON.

O'Betz, in front of station; top of rail:

Feet.

Bannon, 0.82 mile southeast of station, in southeast corner of south abutment of railroad bridge; aluminum tablet stamped " 753 " ............

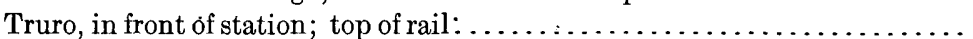

Brice, in front of station; top of rail . . . . . . . . . . . . . . . . . . . . . . .

County line (Franklin and Fairfield); top of rail.....................

Pickerington, in front of station; top of rail . . . . . . . . . . . . . . . . . . .

754. 2

752. 482

769. 9

783. 8

803. 5

840.2

\section{THURSTON QUADRANGLE.}

PICKERINGTON, EAST ALONG THE TOLEDO AND OHJO CENTRAL AND THE ZANESVILLE AND WESTERN RAITAYS, TO NEW SALEM.

Harley, 1.12 miles southeast of, in southwest corner of abutment at west end of railroad bridge over creek; aluminum tablet stamped " 865 ". .....

Basil, in front of station; top of rail . . . . . . . . . . . . . . . . . . . . .

Basil, in front of station in top of stone platform; aluminum tablet stamped

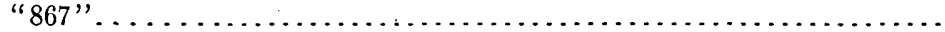

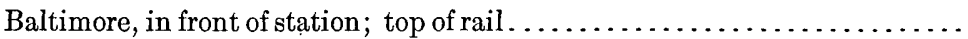

Thurston, in northwest corner of front steps of schoolhouse; aluminum tablet stamped " 886 ".

Thurston, 2.1 miles east of, 230 feet south of track, in northeast corner of highway bridge; aluminum tablet stamped " 935 "...............

\section{THORNVILLE QUADRANGLE.}

NEW SALEM, EAST ALONG ZANESVILLE AND WESTERN RAILWAY, TO POINT EAST OF CHALFANTS POST-OFFICE.

New Salem, in front of station; top of rail. . . . . . . . . . . . . . . . .

New Salem, 0.79 mile east of, 531 feet north of track, in southwest corner of abutment of highway bridge; aluminum tablet stamped " 952 ".

Thornport, in stone step at southwest corner of schoolhouse; aluminum tablet stamped " 900 ".

Thornport, in front of station; top of rail......................

Thornport, 2.27 miles east of, south of track, in northwest corner of retaining wall of high way bridge; aluminum tablet stamped " 880 ". . . . . . . .

Thornport, 2.93 miles east of, at Zanesville and Western Railway and Baltimore and Ohio Railroad crossing; top of rail . . . . . . . . . . . . . . . .

Walser, in front of station; top of rail. . . . . . . . . . . . . . . . . . . .

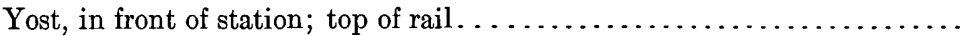

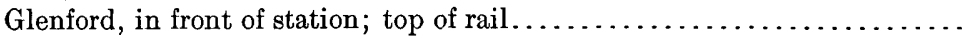

Glenford, in southwest corner of stone step at southeast side of schoolhouse;

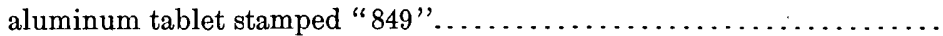

Glenford, 30 feet west of railroad, in southeast corner of abutment of small bridge; aluminum tablet stamped " 844 ".......................

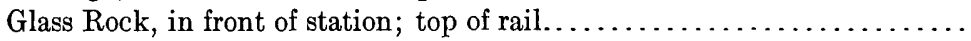

Glass Rock, 1.2 miles east of, in southeast corner of abutment of bridge;

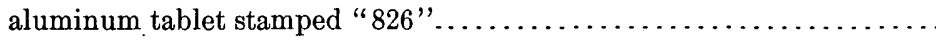

880.065

846.6

849. 109

\section{ZANESVILLE QUADRANGLE.}

POINT EAST OF CHALFANTS POST-OFFICE, EAST ALONG ZANESVILLE AND WESTERN RAILWAY, TO ZANESVILLE.

Mount Perry, 254 feet west of station, in abutment at northeast corner of covered highway bridge; aluminum tablet stamped " 801 " . . . . . . . . . 
Mount Perry, 2.31 miles east of; 30 feet south of track, in northwest corner of foundation of highway bridge; aluminum tablet stamped " 797 ". . .

Fultonham, 0.09 mile west of, in northwest corner of stone foundation of water tank; aluminum tablet stamped " $763 "$ "..................

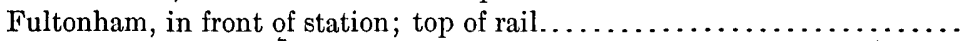

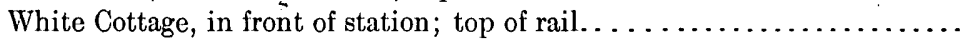

White Cottage, 0.76 mile east of, in abutment at southeast corner of bridge;

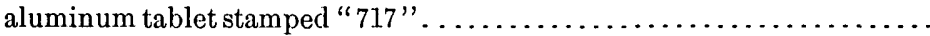

Elizabeth, in front of station; top of rail.......................

Elizabeth, 2.12 miles northeast of, 1.72 miles south west of South Zanesville, at crossing of Zanesville and Western Railway and Cincinnati and Muskingum Valley Railroad; top of rail. . . . . . . . . . . . . . . . . . . .

South Zanesville, 0.36 mile southwest of, on east side of railroad, in stone;

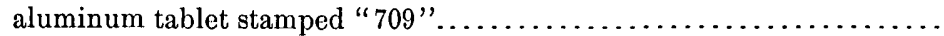

South Zanesville, in front of station; top of rail. ..................

Zanesville, in front of station; top of rail. . . . . . . . . . . . . . . . .

Feet.

797. 587

762.935

762. 3

734. 0

716. 939

723. 7

715. 2

709. 576

728. 6

704. 0

\section{PHILO QUADRANGLE.}

ZANESVILLE, ALONG BALTIMORE AND OHO RAILROAD, TO SUNDALE.

Zanesville, in top step at south side of court-house; aluminum tablet stamped

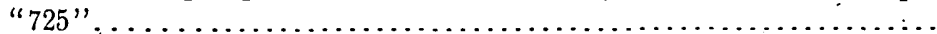

Zanesville, south side of court-house, 12 feet east of doorstep, at southwest corner of pillar, in top step of portico; aluminum tablet stamped " 725 "..

Zanesville, on upper river wall of Lock 1.0 (U. S. Engineer Corps bench mark 1); cut "U. S. ( B. M. 699.73 ".......................

Zanesville, on upper river wall of Lock 10 (U. S. Engineer Corps bench mark 2); cut "U. S. (B. M. 699.92 ".........................

Zanesville, 3.94 miles northeast of, in east side of concrete culvert; aluminum tablet stamped " 778 ". .

Sonora, 40 feet northeast of Baltimore and Ohio Railroad station; iron post stamped " 808 ".

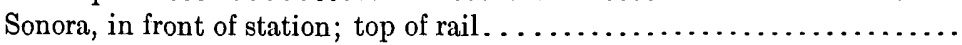

Sonora, 1.99 miles northeast of, in concrete railroad culvert, south side; aluminum tablet stamped " 778 " . . . . . . . . . . . . . . . . . . .

Sonora, 4.13 miles northeast of, in southwest corner of stone foundation of water tank; aluminum tablet stamped " 770 "...................

Sonora, 6.96 miles northeast of, 30 feet north of track; iron post stamped " 886 ".

Sundale, in front of station; top of rail

725. 721

699. 1.17

699. 300

778. 516

808. 637

808. 0

778. 596

770. 162

886.055

886. 1

CUMBERLAND QUADRANGLE.

SUNDALE, ALONG BALTIMORE AND OHIO RALROAD, TO CAMBRIDGE.

New Concord, 60 feet north of station; iron post stamped " 843 ". ........

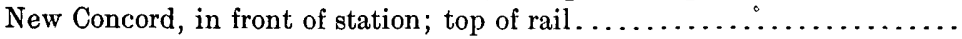

New Concord, 2.7 miles northeast of, 50 feet south of track, in fence corner;

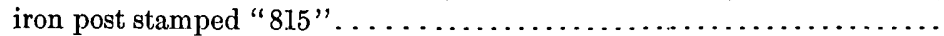

Cassell, 60 feet north of railroad, in northeast corner of top of stone abutment to highway bridge; aluminum tablet stamped " 804 ".............

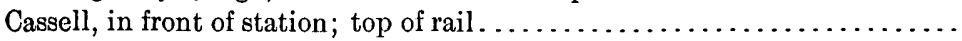

Cassell, 1.83 miles northeast of, in concrete culvert south of track; aluminum

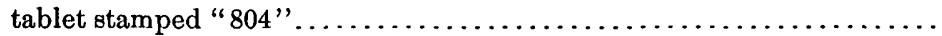


CAMBRIDGE QUADRANGLE.

CAMBRIDGE, NORTH ALONG PENNSYLVANIA RALROAD, TO NEAR GUERNSEY.

Cambridge, in top of south side stone steps to court-house, 1 foot from building; aluminum tablet stamped " 886 ".

Feet.

885. 833

Cambridge, in front of Baltimore and Ohio Railroad station; top of rail.... Cambridge, in front of Cleveland and Marietta Railway station; top of rail. .

Cambridge, 2.83 miles north of, in top of stone abutment at northwest corner of railroad bridge; aluminum tablet stamped " 804 ".

803. 0

804. 5

Cambridge, 6.33 miles north of, 20 feet west of track, 10 feet north of highway; iron post stamped " 783 ".

804. 475

783. 742

Cambridge, 9.03 miles north of, 15 feet west of railroad; iron post stamped " 787 "

Cambridge, 10.99 miles north of, in stone at northwest corner of S. W. Luscock's barn; aluminum tablet stamped " 787 " . . . . . . . . . . . . . .

Kimbolton, in front of station; top of rail . . . . . . . . . . . . . . . . .

Kimbolton, 4.93 miles north of, 30 feet west of railroad, in top of southeast corner of stone abutment to highway bridge over creek; aluminum tablet

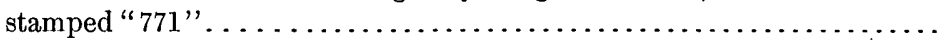

Birds Run, in front of station; top of rail. . . . . . . . . . . . . . . . . .

Guernsey, in front of station; top of rail. . . . . . . . . . . . . . . . . . .

Guernsey, in front of station, 30 feet west of track, I foot from railroad prop-

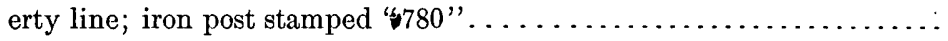

Guernsey, 3.26 miles north of, 25 feet west of railroad, 10 feet from highway;

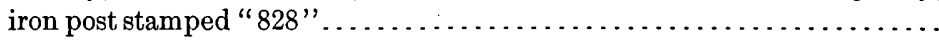

787. 161

787. 164

787. 2

770. 786

774.3

783. 8

780. 594

828. 391

NEW COMERSTOWN QUADRANGLE.

guernsey, northeast along penNsylvania rallroad, to port washington

Guernsey, 6.69 miles north of, crossing of Pennsylvania lines and Cleveland

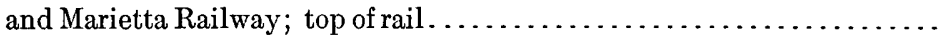

New Comerstown, 3.69 miles east of, 40 feet north of track; iron post

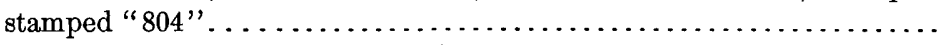

New Comerstown, 5.42 miles east of, on stone foundation of Pennsylvania Railroad water tank; chiseled square (railroad bench mark 816.10) . . .

New Comerstown, 6.18 miles east of, 30 feet south of railroad, 20 feet west of highway; iron post stamped " 817 ".

803. 0

804.718

817.874

817.856

Port Washington, in front of station; top of rail . . . . . . . . . . . . . . .

820. 2

UHRICHSVILLE QUADRANGLE.

PORT WASHINGTON, EAST alONg PENNSYlVANIA RAILROAD, TO UHRICHSVILle.

Port Washington, 3.88 miles east of, 414 feet north of railroad, in top of southeast corner of stone abutment for locks of canal; aluminum tablet stamped " 834 ".

834.859

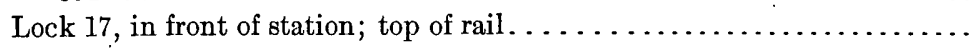

Gnadenhutton, 35 feet north of railroad, in front of station; iron post stamped " 834 ".

Gnadenhutton, in front of station; top of rail.

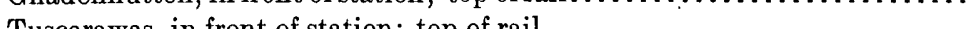

Tuscarawas, 0.24 mile east of, in top of northwest corner of abutment to bridge over highway; aluminum tablet stamped " 844 ". . . . . . . . . . .

Uhrichsville, 0.86 mile north of, in southwest corner of abutment at south end of overhead railroad bridge; small bolt (Baltimore and Ohio Railroad.

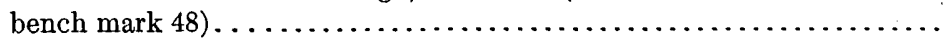

831. 1

834. 549

836. 3

844. 3

844. 738 
UHRICHSVILLE, EAST ALONG PENNSYLVANI RAILROAD, TO STATION FTFTEEN POST-OFFICE.

Uhrichsville, in front of Pennsylvania Railroad station; top of rail........

Uhrichsville, 0.52 mile east of, 3 feet south of railroad track, 2 feet from ground, in stone foundation of overhead highway bridge; aluminum

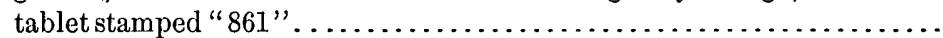

Dennison, in front of station; top of rail. . . . . . . . . . . . . . . . . . . .

Dennison, 0.46 mile east of, stone abutment of bridge over creek; Pennsylvania Railroad bench mark (856.14?).

Feet.

856. 8

Dennison, 3.49 miles east of, in northeast coping of northwest wing wall of stone-arch bridge No. 86; aluminum tablet stamped " 868 STBNVL"....

\section{PRIMARY LEVELING.}

\section{CHARDON, CONNEAUT, AND JEFFERSON QUADRANGLES.}

\section{ASHTABULA AND GEAUGA COUNTIES.}

The leveling in Chardon quadrangle was done in 1903 by C. H. Moore, in Chardon and Jefferson quadrangles in 1904 by C. R. Harvey, and in Conneaut quadrangle in 1904 by E. I. Shea.

\section{CHARDON QUADRANGLE.}

PAINESVILLE, SOUTH ALONG BALTMORE AND OHO RAILROAD, TO CHARDON; THENCE SOUTHEAST along CLEVELAND AND CHARDON ELECTRIC RAILWAY, TO BASS LAKE.

Painesville, on front entrance step at southeast corner of court-house; chiseled circle.

Feet.

Painesville, on east side of Soldiers' monument in City Park, in lower water table; aluminum tablet stamped "678 CLEVELAND".

Concord, north side of Painesville-Concord road, 200 feet west of Baltimore and Ohio Railroad crossing; in top of 2 by 5 foot sandstone coping stone, in center of culvert, bronze tablet stamped " 897 CLEVELLAND" ..........

Painesville, 6.25 miles south of, on culvert stone on east side of Baltimore and Ohio Railroad track, south side of east-west road crossing; chiseled square........................................... 1, 013.46

Chardon, southwest corner Court and Washington streets, north side, at northeast corner of frame house, in foundation wall; bronze tablet stamped " 1233 CLEVELAND" .......................... 1, 232. 770

FOWLERS MILLS, EAST TO HUNTSBURG; THENCE NORTH TO MADISON.

Claridon, 1.25 miles .west of, southeast side of bridge over outlet branch Cuyahoga River, flush in abutment; , bronze tablet stamped "CLEVE-

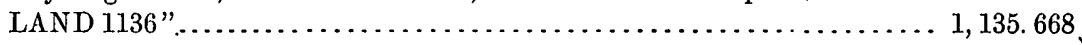

East Claridon, 0.5 mile east of, in northwest corner of bridge over Cuyahoga River, in abutment stone; aluminum tablet stamped "CLEVELAND

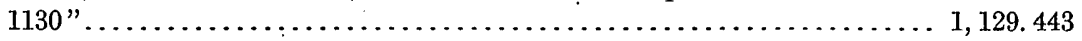

Huntsburg, 2 miles north by 1 mile west of, southeast corner of crossroads, in northwest corner of foundation of frame farmhouse; aluminum tablet stamped "CLEVELAND 1283 "............................ 1, 282.459

Montville, in southwest corner of M. E. Church; aluminum tablet stamped "CLEVELAND 1239 ".

South Thompson, 25 feet south of post-office, east side of road, in stone foundation of frame house; bronze tablet stamped "CLEVELAND $1170 "$ 
Thompson, in southwest corner of stone foundation of Congregational Feet. Church; bronze tablet stamped "1277 CLEVELAND" .............. 1, 276. 266

Madison, 2.5 miles south of; in southwest corner of bridge over Grand River, in abutment stone; aluminum tablet stamped " 696 CLEVELAND"....

695. 761

\section{JEFFERSON QUADRANGLE.}

MILL CREEK, SOUTH ALONG HIGHWAY, TO JEFFERSON; THENCE WEST TO CORK; THENCE SOUTH TO WINDSOR; THENCE EAST TO COLEBROOK; TIENCE NORTH TO JEFFERSON.a

Jefferson, in stone floor of front entrance way to court-house; aluminum tablet stamped "968 CLEVELAND"..........................

Eaglesville, 75 feet south of crossroads, flush in top of culvert; aluminum

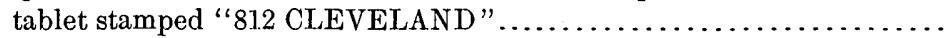

Cork, in northwest corner of brick schoolhouse, southeast corner of roads; bronze tablet stamped "974 CLEVELAND"......................

Trumbull, in northwest corner of stone foundation of town hall; aluminum tablet stamped " 995 CLEVELAND" ..........................

Hartsgrove, in northeast corner of public school; bronze tablet stamped "1033 CLEVELAND"

Windsor, in northeast corner of stone foundation of I. O. O. F. hall; aluminum tablet stamped " 835 CLEVELAND"....................

Orwell, in northeast corner of Orwell Banking Company Building; aluminum tablet stamped " 903 CLEVELAND".

Colebrook, 1 mile west of, in culvert stone; aluminum tablet stamped " 922 CLEVELAND"

South New Lyme, in northeast corner of Presbyterian Church; aluminum tablet stamped "968 CLEVELAND".

966.728

Lenox, 2.5 miles south of; 75 feet south of crossroads, east side of northsouth road, in top of stone culvert; aluminum tablet stamped " 946 CLEVELAND".

Lenox, 0.25 mile south of, west side of road, in abutment stone of culvert; aluminum tablet stamped " 932 CLEVELAND"..................

\section{CONNEAUT QUADRANGLE.}

PENNSYLVANIA-OHO STATE LINE, WEST ALONG PENNSYLVANIA AND OHIO ELECTRIC RAILROAD TRACKS, TO ASHTABULA.

Conneaut, in southeast corner of hotel Cleveland, in face of stone foundation wall; aluminum tablet stamped " 662 CLEVE".

North Kingsville, in face of stone sill at northwest corner of large brick building at southeast cornęr of crossroads; aluminum tablet stamped " 715 CLEVE",

CONNEAUT, SOUTH ALONG HIGHWAY, TO PIERPONT; THENCE WEST TO BRIDGE NORTH OF JEFFERSON.

Farnham, 0.3 mile south of former post-office, in south wing wall on southeast end of covered bridge No. 1 over Conneaut Creek; bronze tablet stamped "745 CLEVELAND 1904".

Bushnell, south abutment stone on west side of iron girder bridge over Ashtabula Creek, 800 feet south of former post-office; aluminum tablet stamped "865 CLEVE".

Monroe Center, in top of stone culvert on west side of road; bronze tablet

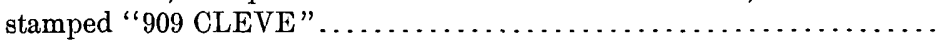


Pierpont, in stone base at northeast corner of Congregational Church; bronze tablet stamped " 995 CLEVE".

Giddings, in west end of culvert stone on north side of road 630 feet west of post-office; aluminum tablet stamped " 952 CLEVE"................

Griggs Corners, 300 feet south of former post-office, in top stone of north wing wall at northeast corner of iron girder bridge over Griggs Creek; aluminum tablet stamped " 881 CLEVE"

AKRON, ASHTABULA, BEREA, CLE ELAND, EUCLID, KENT, MENTOR, OBERLIN, AND PERRY QUADRANGLES.

ashtabula, cuyahoga, geauga, lake, lorain, portage, and summit counties.

The leveling in Cleveland, Berea, and Oberlin quadrangles was done in 1901 by George Bailey; in Euclid, Perry, Mentor, and part of Ashtabula quadrangles in 1903 by C. H. Moore; in Ashtabula quadrangle in 1903 by H. S. Lowe; and in Akron and Kent quadrangles in 1903 by W. E. Earle and E. I. Shea.

\section{CLEVELAND QUADRANGLE.}

Cleveland, east along highway, to warkensville; thence souti to Macedonia.

Cleveland, southwest corner of Front and East River streets, Johnson House Block, northeast corner, a cross (+) on water table (U. S. Engineer

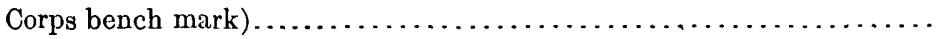

Cleveland, Lake Erie; U. S. Engineer Corps water-table zero mark (mean elevation of lake for years $1860-1875$, inclusive) $\ldots \ldots \ldots \ldots \ldots \ldots \ldots$

Cleveland, Lake Erie; U. S. Engineer Corps water-gage readings (mean elevation for years $1886-1900$, inclusive).$\ldots \ldots \ldots \ldots \ldots \ldots \ldots \ldots \ldots \ldots$

Cleveland, Superior street, in front of Soldiers' monument in public square, west end of coping; aluminum tablet stamped " 668 CLEVELAND 1.901"

Warrensville, brick schoolhouse, west end of, north face, in foundation 1 foot from ground; bronze tablet stamped "1046 CLEVEL $\Lambda$ ND 1901".. 1, 047. 794

Bedford, 2.5 miles northeast of, red brick schoolhouse at intersection of 5 . roads, left side of door, bottom step near wall; small square ........... 1, 082.C7

CLEVELAND, VIA NORTII ROYALTON AND BOSTON, TO MILLERS CORNERS.

Cleveland, Big Four Railway Bridge over Cuyahoga River, southeast side of track, on east end of abutment; chiseled cross.

North Royalton, Church of Christ, east face of foundation, about 2 feet from ground; bronze tablet stamped "1237 CLEVELAND 1901".......... 1, 236. 640

Boston, between Cuyahoga River and mill race to paper mill, southeast corner of masonry pier; bronze tablet stamped "664 CLEVELAND"...

663.815

BEREA QUADRANGLE.

PARMA, VIA BENNETTS CORNERS AND HARDSCRABBLE, TO CROSSROADS 3 MILES EAST OF GRAFTON.

Bennetts Corners, on southwest corner of crossroads, in top of end of drain; bronze tablet stamped "1058 CLEVELAND 1901".............. 1,058.088

Hardscrabble, bridge over west branch of Rocky River, northeast sill; bronze tablet stamped "794 CLEVELAND 1901 "................

Hardscrabble, 2 miles west of, bridge over stream to north, on northeast corner of northwest abutment; mark. 
WEST CLEVELAND, VIA ROCKY RIVER, TRINITY, AND BEREA, TO PARMA.

Rocky River, 200 feet east of station; small New York, Chicago, and St. Louis Railroad bridge over private road, southwest abutment, in sill between girder and capstone, about 2 feet below rail; aluminum tablet stamped "655 CLEVELAND 1901". . .

654.865

Trinity, brick schoolhouse north of former post-office, front or west face of window sill south of doorway; aluminum tablet stamped " 696 CLEVE-

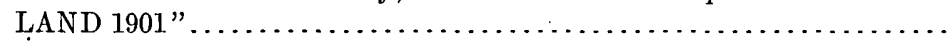

Berea, bridge over East Branch (of Rocky River), southeast wing wall, about 2 feet above highway; aluminum tablet stamped "769 CLEVE-

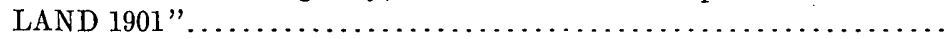

Parma, 1.25 miles southwest of, in sill at northeast end of bridge on the Cleveland-Medina pike, southeast side of road; aluminum tablet stamped "846 CLEVELAND 1.901"...................................

Feet.

696. 636

769. 354

846.094

OBERLIN QUADRANGLE.

EAGLE CLIFF, VIA LORAIN, NORTH AMHERST, AND ELYRIA, TO NORTH RIDGEVILLE.

Lorain, Erie Street Bridge over Black River, north side of street, inside railing, west abutment; aluminum tablet stamped " 598 CLEVELAND $1901 "$ ".

North Amherst, 0.75 mile west of, east wall of Lake Shore and Michigan Southern Railway bridge, in third course of stone 5 feet 4 inches from ground, in eighth stone from south end; bronze tablet stamped " 678

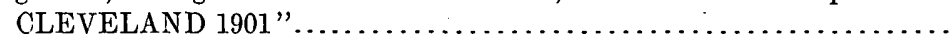

Elyria, in top of foundation stone at northwest corner of court-house; aluminum tablet stamped "721 CLEVELAND 1901"...................

598. 346

SOUTH AMHERST, VIA OBERLIN AND GRAFTON, TO FIELDS.

Oberlin, northwest corner of Lorain and Professor streets, Severance Laboratory of Oberlin College, in southeast corner of east wing; aluminum tablet stamped "817 CLEVELAND 1901" (Set at same elevation as old tablet removed by destruction of entrance wall).

816. 872

Grafton, 0.5 mile southwest of, highway bridge over East Branch (of Black River), in top of northeast wing wall; bronze tablet stamped "793

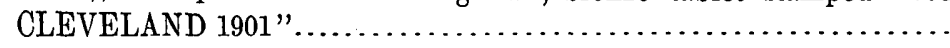

\section{AKRON QUADRANGLE.}

hUDSON, West aLONG HighWAY, to PENINSULA; theNCE SOUTH, VIA EVERETT, tO AKRON.

Peninsula, in northwest corner of city hall; aluminum tablet stamped "711 CLEVELAND".

Everett, east side of canal lock, in third stone from south gate; chiseled cross.

Ira station, iron bridge over Cuyahoga River, northwest stone pillar; in top stone; chiseled cross.

Botzum, in northeast stone abutment of bridge over Ohio Canal; aluminum tablet stamped "753 CLEVELAND".

752.890

Cranmer flag station, 1,000 feet north of, southeast stone abutment of road bridge over canal, in second step from bottom; chiseled cross...........

Akron, 1.5, miles north of, fifth canal lock north of West North street, in northeast corner of stone wall; chiseled cross....................

Akron, 175 feet west of Howard street station, iron bridge of Cleveland, Terminal and Valley Railroad over Howard street, in southeast stone abutment; chiseled cross................................ 
AkRoN, WESt ALONG HighWAY, viA COPLEY, tO SHARON CENTER; THENCE NORTh to WEST RICHFIELD; THENCE EAST TO PENINSULA.

Copley, 1.5 miles east of, iron bridge over Pigeon Creek, Northern Ohio Feet.

Railroad, 20 feet east of crossroad, southeast corner of stone abutment; chiseled cross.

Copley, in southwest corner of Disciples Church; aluminum tablet stamped "1049 CLEVELAND"..

Copley, 1.3 miles west of, in northwest corner of road forks, 75 feet east of road crossing north and south, at house of $\mathrm{E}$. Bigelow, in south top stone to small culvert; chiseled cross.

Copley, 2.3 miles west of, at southeast corner of J. M. Andrews house, northwest corner of forks of ruad on Medina-Summit county line, in large top stone of culvert; cut.

Sharon Center, 1 mile east of, Sharon Township, east side of road, southwest corner of foundation of barn owned by Jennie Hollinger; aluminum tablet stamped "1044 CLEVELAND".

Granger, 1.25 miles east of, Granger Township, southeast corner of forks of roads, in south side of top stone to stone culvert; aluminum tablet stamped

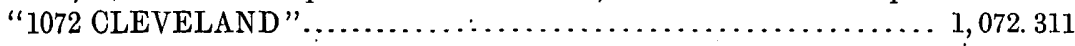

Richfield, 1 mile south of, west side of road, 1,100 feet north of forks of Medina-Brecksville road, top of culvert; chiseled cross........... 1, 224. 20

West Richfield, in southeast corner of Carter House; aluminum tablet stamped "1279 CLEVELAND".

Peninsula, 2 miles west of, south side of road, at forks east, west, and northeast, in top stone to culvert; chiseled cross.

EAST AKRON, SOUTHWEST ALONG HIGHWAY, TO BARBERTON; THENCE WEST ALONG ERIE RAIIROAD, TO WADSWORTH; THENCE NORTH ALONG HIGHWAY, TO SHARON CENTER.

Akron, northeast corner of east porch of county jail; aluminum tablet stamped "1027 CLEVELAND" (on checked spur line)........... 1,027. 182

Barberton, 1.5 miles north of, in southeast corner of stone bridge with iron hand rails over drain east of Lawndale; chiseled cross................

Barberton, at right side of main entrance stairway of Barberton Inn in face of support to veranda; aluminum tablet stamped "981 CLEVELAND"

Barberton, 1.5 miles west of station; Erie Railroad milestone 210 ; cross chiseled on top................................... 012.70

Sherman, 35 feet east of Erie Railroad station; in top of milestone 212; bronze tablet stamped " 1085 CLEVELAND"................. 1, 085.476

Wadsworth, Wadsworth National Bank, 1 foot south of doorway, in face of foundation stone; bronze tablet stamped "1170 CLEVELAND"....... 1, 170: 404

Wadsworth, 4 miles north of, at southeast corner of crossroads, in top of large stone post; chiseled cross . ......................... 1,089. 27

Sharon Center, Sharon Township, at southwest corner of Universalist Church, in face of stone foundation; bronze tablet stamped "1028 CLEVELAND". 1, 027. 748

\section{KENT QUADRANGLE.}

SILVER LAKE JUNCTION, EAST ALONG GAYLOR ROAD, TO MUNROE FALLS; THENCE ALONG BALTIMORE AND OHIO RAILROAD, TO KENT; THENCE ALONG HIGHWA, TO RAVENNa.

Silver Lake junction, in southwest end of large stone-arch bridge over Cuyahoga River, on end coping stone of west wall; aluminum tablet stamped "1012 CLEVELAND $1903 " \ldots \ldots \ldots \ldots \ldots \ldots \ldots \ldots \ldots \ldots \ldots$. $1,012.197$

Munroe Falls, opposite post-office, at southwest corner of crossroads, at northeast corner of schoolhouse, in face of foundation wall on north side; bronze tablet stamped " 1040 CLEVELAND 1903".............. 1, 039. 467 
Kent, 2.5 miles west of, at milepost A. Jct. 8, top of T rail driven in ground Feet. crosscut (B. \& O. R. R. bench marked 431, elevation 1016.670) ...... . 1, 017. 58

Kent, 1.5 miles west of, at milepost A. Jct. 9, on top of $T$ rail driven in ground; crosscut (B. \& O. R. R. bench marked 430, elevation 1016.577) . . 1,017. 48

Kent, at head of stairway leading to railroad station, in stone bridge on south side; bronze tablet stamped "1051 CLEVELAND 1903"......... 1, 051.822

Kent, 2.25 miles east of, at southwest corner of iron bridge over Breakneck Creek, at abutment; chiseled square....................... 1, 046.39

RAVENNA, NORTHWEST ALONG HIGHWAY, TO STREETSBORO; THENCE WEST TO HUDSON; THENCE SOUTH, aLONG PENNSYlVania RAILROAd, to CUYAHOga falls.

Ravenna, 3 miles northwest of, at northwest corner of small bridge over ditch, in stone abutment; chiseled cross...................... 1,065. 00

Ravenna, 5 miles northwest of, Streetsboro Township, at northwest corner of girder bridge over Cuyahoga River, in top of stone abutment; bronze tablet stamped "1054 CLEVELAND 1903 ".................. 1, 054. 306

Streetsboro, Streetsboro Township, on north side at northwest corner of voting place, in stone foundation; bronze tablet stamped " 1136 CLEVE-

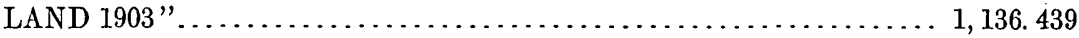

Hudson, 350 feet west of railroad station, on north stone abutment of Pennsylvania Railroad bridge over Peninsula road; bronze tablet stamped " 1049 CLEVELAND"................................ 1,049. 410

\section{EUCLID QUADRANGLE.}

Cleveland, Northeast aLONG highway, to EUClid.

Euclid, 150 feet east of corner of Euclid avenue and Main street, at southwest corner of red brick 2-story building on north side of Euclid avenue, in west face of foundation stone; aluminum tablet stamped "653 CLEVELAND" . . . . . . . . . . . . . . . . . . . . . . . . . . . .

WARRENSVILLE, NORTII ALONG IIIGHAY, TO SOUTH EUCLID.

South Euclid, at southeast corner of lower stone step at front entrance of brick schoolhouse; aluminum tablet stamped " 977 CLEVELAND"....

976. 911

\section{MENTOR QUADRANGLE.}

EUCLID, NORTHEAST ALONG LAKE SHORE AND MICHIGAN SOUTHERN RAILWAY, TO WICKLIFFE; THENCE ALONG JUCLid AVENUE (NORTH RIDGE ROAD), TO PAINESVille.

Wickliffe, at southeast corner of red brick Presbyterian Church, in face; aluminum tablet stamped " 696 CLEVELAND"................

Willoughby, at northeast corner of iron flagstaff in public square; top of

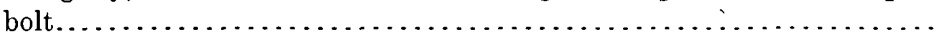

West Mentor, Mentor Township, in front entrance of village hall, at southeast corner of 2 by 3 by 4 foot stepping stone; chiseled square.........

West Mentor, at front entrance of village hall, 2 by 3 by 4 foot carriage stepping stone, at northeast corner; bronze tablet stamped "695 CLEVELAND".

Mentor, 3.5 miles northeast of, at $T$ road north, on south side of Mentor avenue, in center and on top of stone culvert; chiseled square.........

FOWLERS MILL, WEST ALONG HIGHWAY, TO SOUTH EUCLID

Fowlers Mill, 60 feet east of station; north side of east-west road, on top of

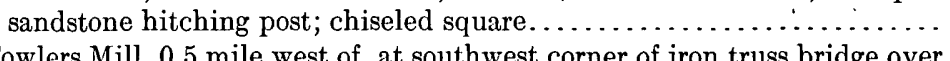

Fowlers Mill, 0.5 mile west of, at southwest corner of iron truss bridge over Chagrin River, at top of northwest corner of top abutment stone; bronze tablet stamped "1111 CLEVELAND"...................... 1, 110. 505 
Fowlers Mill, 1.25 mile west of, at southeast corner of crosstoads, on top of Feet. culvert stone; chiseled square.......................... 090.77

Chesterland, 100 feet southeast from center of crossroads, northwest corner of general store of H. C. Cattrell; bronze tablet stamped "1217 CLEVELAND".

Gates Mill, high truss iron bridge over Chagrin River, at northwest corner of top abutment stone; aluminum tablet stamped "729 CLEVELAND"..

Gates Mill, 2 miles west of, 100 feet west of center of crossroads, north side of road, on top of center of 2 by 2 granite bowlder; chiseled square..... 1, 049. 88

Gates Mill, 4.75 miles west of, 1 mile east of South Euclid, on north side of culvert at crossroads, in center of top stone; chiseled circle......... 1,013. 99

PERRY QUADRANGLE.'

PAINESUILLe, ALONG NORTH RIDGE ROAD, TO LAKE-ASHTABULA COUNTY-LINE ROAD; THENCE SOUTH ALONG SAME, TO POINT 1.75 MILES SOUTH OF UNIONVILLE; THENCE WEST ALONG HIGHWAYS AND SOUTH RIDGE ROAD, TO PAINESVILLE.

Painesville, 5.75 miles northeast of, 100 feet east of $T$ road north, south side of east-west Ridge road, at northwest corner of large frame house, in face of foundation wall, north side; aluminum tablet stamped "686

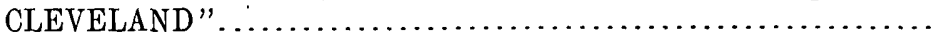

North Madison, 200 feet northeast from center of crossroads, at northwest corner of foundation wall of First Congregational Church, in foundation wall; aluminum tablet stamped " 676 CLEVELAND"...............

Unionville, at southwest corner of crossroads, at front entrance to dry-goods store, on 4 by 4 foot sandstone step; chiseled circle................

Unionville, 1.75 miles south of, 2.75 miles west of Harpersfield. LakeAshtabula county-line road, southwest corner of crossroads, northeast corner of brick house of J. H. Fowler, in face of foundation wall, east side, 1 foot above ground; bronze tablet stamped " 856 CLEVELAND". .

Madison, on west side of northwest corner of foundation of town hall; bronze tablet stamped " 744 CLEVELAND". . . . . . . .................

Madison, 2 miles west of, at crossroads on south side of east-west road, at west end of 2.5 by 4 foot sandstone over culvert; chiseled circle.........

686.461

676. 196

744. 35

856. 198

743. 511

730.54

ASHTABUla' QUADRANGLE.

NORTH MADISON, EAST ALONG NORTH RIDGE ROAD, VIA GENEVA, TO SAYBROOK; THENCE EAST TO ASHTABULA; THENCE SOUTH AND WEST ALONG HIGHWAYS, TO UNIONVILLE.

Geneva, at public square, Ford \& Tibbets 3-story brick building, in top of first stone window sill east of stairway; aluminum tablet stamped " 675 CLEVELAND".

Geneva, 4 miles east of, Saybrook Township, 75 feet east of T road south, south side of east-west road, on top of top stone of culvert; chiseled

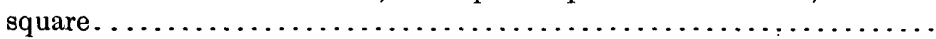

Saybrook, in brick foundation of town hall, on north side at northwest corner; bronze tablet stamped " 682 CLEVELAND".

Ashtabula, at front entrance to city hall, northwest corner of top step; aluminum tablet stamped "700 CLEVELAND"

Ashtabula, 6.75 miles south of, Jefferson Township, northeast corner of high iron-truss bridge, over Mill Creek, in top of abutment wall; bronze tablet

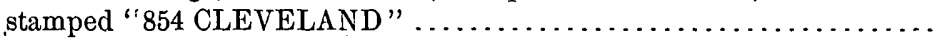

Austinburg, at northwest corner of crossroads, on south side of southeast corner of brick store, in face of water table; bronze tablet stamped " 817 CLEVELAND" .....................................

Harpersfield, on south side of southwest corner of town hall, in face of brick wall, 2 feet above ground; bronze tablet stamped "859 CLEVELAND". . 
ANDOVER, BRISTOLVILLE, CHAGRIN FALLS, GARRETTSVILLE, AND KINSMAN QUADRANGLES.

ashtabula, cuyahoga, geadga, portage, summi, and trumbull countes.

The leveling in these quadrangles was done in 1905 by R. C. Seitz.

ANDOVER QUADRANGLE.

LENOX, EAST ALONG HighWAY, TO RICHMOND CENTER; THENCE NORTH to PIERPONT.

Lenox, 3.6 miles east of, 450 feet east of township line, in northeast corner of abutment of small iron bridge over Mill Creek, set flush in top; aluminum tablet stamped " 985 ADJ 1903 ".

984. 827

Dorset, south end of, in southwest corner of foundation of town hall; aluminum tablet stamped " 985 ADJ 1903 ".

985. 069

Richmond Center, 950 feet west of crossroads, in top of southwest corner of west abutment of small iron bridge over creek; aluminum tablet stamped "1031 ADJ 1903".

Pierpont, 3.35 miles south of, in north end of east guard of stone culvert 0.8 mile south of township line; aluminum tablet stamped "1046 ADJ 1903". 1, 045. 633

RICHMOND CENTER, SOUTH ALONG HIGHWAY, TO ANDOVER AND 1 MILE SOUTH; THENCE WEST TO SOUTH NEW LYME.

Andover, Mosley Block, flush in base stone at southeast corner of building occupied in 1905 by the Bank of Andover; aluminum tablet stamped "1091 ADJ 1903"....................................... 1, 091.012

Andover, 1.04 miles south by 3.91 miles west of, 435 feet east of crossroads, in top of west end of north guard stone culvert; aluminum tablet stamped "996 ADJ 1903".

Cherry Valley, 1.04 miles south by 2.72 miles west of, in south west corner of foundation of house north side of road, 250 feet east of $T$ road south, 0.35 mile west of township line; aluminum tablet stamped "1079 ADJ 1903". 1, 079. 106 COLEBROOK, EAST ALONG HIGHWAY 2 MILES; THENCE SOUTH 2 MILES; THENCE EAST AND NORTH to ANDOVFR.

Colebrook, 2.1 miles east by 1.52 miles south of, 0.95 mile north of county line, 550 feet south of T road west, in west guard of stone culvert; aluminum tablet stamped "1024 ADJ 1903 ".

Wick, 1.83 miles south of, 270 feet south of $T$ road east, in west foundation of house, 5 feet north of porch; aluminum tablet stamped " 997 ADJ

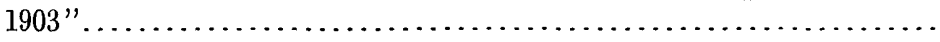

Williamsfield, 0.65 mile north of, in east side* of south abutment of bridge over McMichael Creek; aluminum tablet stamped "1113 ADJ 1903"...... 1, 112. 761

\section{CHAGRIN FALLS QUADRANGLE.}

MACEDONIA, EAST ALONg HIGHWAY, TO TWINSBURG; THENCE NORTH TO BARRY; THENCE EAST TO PUNDERSON LAKE.

Twinsburg, in culvert in southeast triangle of road crossing; aluminum

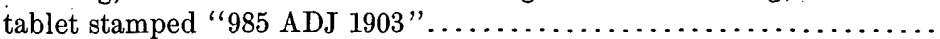

Solon, in belt line at northwest corner of town hall; aluminum tablet stamped "1037 ADJ 1903".

Barry, at center of Orange Township, in southeast corner of foundation of town hall, 325 feet south of crossroads; aluminum tablet stamped " 1031 ADJ 1903"

Russell Center, in southeast corner of foundation of town hall; aluminum tablet stamped "1094 ADJ 1903 "............................ 1,094. 028

Ford, 0.91 mile west of, in south wing wall, east abutment of small iron bridge; aluminum tak'et stamped "1162 ADJ 1903"................ 1, 161.918 
AUBURN, WEST ALONG HIGHWAY, TO BAINBRIDGE; THENCE SOUTH TO AURORA; THENCE WEST TO TWINSBURG.

Bainbridge, at crossroads, in east culvert west side of road; aluminum tablet stamped "1166 ADJ 1903".

Feet.

Aurora, 635 feet north of crossroads, in stone culvert west side of road; aluminum tablet stamped "1119 ADJ 1903".

GARRETTSVILLE QUADRANGLE.

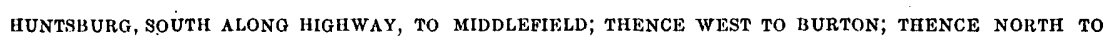
CLARION.

Middlefield, in northwest corner of foundation of town hall; aluminum tablet stamped "1141 ADJ 1903"............................ 1, 141. 330

Burton, in southeast corner of foundation of town hall; aluminum tablet stamped "1338 ADJ 1903 "............................... 1,337.833

BURTON, WEST ALONG EASTERN OHIO RAILROAD, TO LAKE PUNDERSON; THENCE TO FOWLERS MILL.

Punderson Lake station, 0.5 mile north of; 430 feet east of railroad, in culvert stone north side of road; aluminum tablet stamped "1148 ADJ 1903" 1, 148.339

WEST FARMINGTON, WEST ALONG HIGHWAY, TO PARKMAN; THENCE SOUTH TO WINDHAM.

Parkman, 1.5 miles northeast of, crossroads at center of township, east of road, in culvert stone; aluminum tablet stamped "1143 ADJ 1903 "..... 1, 143. 435

Nelson, in town hall, southeast corner of foundation; aluminum tablet stamped "1068 ADJ 1903"............................ 1,068. 498

FREEDOM, NORTH ALONG HIGHWAY, TO TROY CENTER (WELSHFIELd POST-OFFICE); THENCE EAST to PARKMAN.

Hiram, in northwest corner of foundation to brick store building, opposite Y. M. C. A.; aluminum tablet stamped " 1270 ADJ 1903 ".......... 1, 269.642

Troy Center (Welshfield post-office), in northwest corner of foundation of schoolhouse; aluminum tablet stamped "1227 ADJ 1903"........... 1,227. 204

SHALERSVILLE, NORTH ALONG HIGHWAY, TO AUBURN.

Mantua Center, in northwest corner of foundation of schoolhouse; aluminum tablet stamped "1180 ADJ $1903 " . . . \ldots \ldots \ldots \ldots \ldots \ldots \ldots \ldots \ldots \ldots \ldots . \ldots \ldots . .1,180.161$

Auburn Center, Grange Hall, in southeast corner of foundation; aluminum tablet stamped " 1231 ADJ 1903 "............................ 1, 231. 332

BRISTOLVILLE QUADRANGLE.

KENILWORTH, WEST ALONG HIGHWAY, TO MESOPOTAMIA; THENCE NORTH TO WINDSOR.

Greene, 1.25 miles west of, 61.0 feet east of crossroads, north side of road, in culvert stone; aluminum tablet stamped " 918 ADJ 1903 "............

North Bloomfield, 1,035 feet west of Lockwood station, in south end of west abutment of wooden bridge; aluminum tablet stamped " 899 ADJ $1903 "$.

918. 320

North Bloomfield, 1.75 miles west of, north end of east abutment of Grand River bridge; aluminum tablet stamped " 810 ADJ 1903 ".............

Mesopotamia, in west foundation of town hall; aluminum tablet stamped "857 ADJ 1903".

MESOPOTAMTA, SOUTH ALONG HIGHWA, TO WEST FARMiNGTON; THENCE EAST TO MECCA.

West Farmington, in foundation of town hall; aluminum tablet stamped

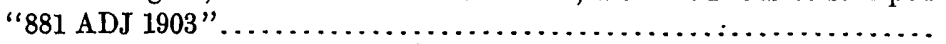


Bristolville, Hotel Brockett, in support of porch, west end; aluminum tablet stamped "902 ADJ 1903".

Feet.

West Mecca, 1.2 miles west of, in south wing of east abutment of small wooden bridge; aluminum tablet stamped "927 ADJ 1903 "...........

927. 476

CORTLAND, SOUTHWEST ALONG HIGHWAY, tO CHAMPION STATION; THENCE WEST TO SOUTHNGTON; THENCE SOUTH TO BRACEVILLE.

Champion, 0.5 mile east of station, at $T$ road south, in south wing of west abutment of small iron bridge; aluminum tablet stamped "925 ADJ $1903 "$.

State Road, 0.3 mile north of, in culvert stone east of road; aluminum tablet stamped "928 ADJ 1903".

Southington, at northwest corner of town hall; aluminum tablet stamped "892 ADJ 1903".

Phalanx (center), 0.2 mile north of, in east wing, south abutment of bridge over Eagle Creek; aluminum tablet stamped "910 ADJ 1903"...........

909. 931

\section{KINSMAN QUADRANGLE.}

POINT NEAR TRIUMPH, SOUTH ALONG HIGHAY, TO NEAR CHADWICK.

Kenilworth, house on north side of road at crossroads, in northeast corner of foundation; aluminum tablet stamped "951. ADJ 1.903 ".

951.431

Kenilworth, 2 miles south of, in top of east wing of north abutment of bridge, 220 feet south of T road east; aluminum tablet stamped " 922 ADJ 1.903".

Mecca, 835 feet south of crossroads, in culvert stone on west side of road; aluminum tablet stamped " 926 ADJ 1.903 "

921.890

925.620

Mecca, 1.5 miles south of, at T road east; iron post stamped "Sta. No. 34" "936 ADJ 1903"

936. 350

Cortland, 1.25 miles southwest of, in west side of Erie Railroad culvert;

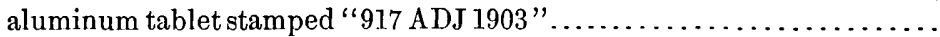

Cortland, 4.75 miles south of, in culvert stone, east side of road at $T$ road northeast; aluminum tablet stamped "916 ADJ 1903"

WILLAaMSFTELd, SOUTH ALONG HIGHWAY, VIA KINSMAN, TO VERNON: THENCE WEST TO MECCA.

Williamsfield, 2.54 miles south of, 610 feet south of crossroads and county line, in north end west guard culvert stone; aluminum tablet stamped "1119 ADJ 1903".

Kinsman, south side of public square, in northwest corner of foundation of brick block; aluminum tablet stamped "940 ADJ 1.903"

Vernon, in southwest corner of foundation of schoolhouse; aluminum tablet stamped "947 ADJ 1903".

946. 460

Vernon, 2.5 miles west of, in culvert stone, south side of road; aluminum tablet stamped "1006 ADJ 1903"

Johnstonville, house in northeast corner of crossroads, southwest corner of foundation; aluminum tablet stamped "1081 ADJ 1903"

$1,081.305$

VERNON, SOUTH ALONG HIGHWAY, TO BROOKFTELD.

Burghill, 1.75 miles south of, 670 feet south of T road east, in north west corner of foundation of house; aluminum tablet stamped "1153 ADJ 1903"... I, 152.893

Brockway, 2.5 miles south of Hartford, in southwest wing, south abutment, bridge over Yankee Creek; aluminum tablet stamped "965 ADJ 1903"..

964.716

BROCKWAY, WEST ALONG HIGHWAY, TO NEAR CHADWICK.

Tyrrell, crossroads, in support of porch of store; aluminum tablet stamped

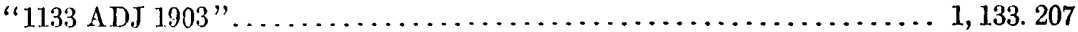




\section{RAVENNA, WARREN, AND YOUNGSTOWN QUADRANGLES.}

\section{Mahoning, Portage, ANd TRUMBULL counties.}

The elevations in the following list are controlled principally by precise leveling of the Baltimore and Ohio Railroad, crossing each quadrangle, and a precise line of the Coast and Geodetic Survey crossing Warren and part of Youngstown quadrangles. A checked primary connection was obtained in 1907 at Niles between these lines which proved a previously supposed error to exist in the Baltimore and Ohio Railroad levels between Youngstown and Niles, and this error has been taken account of in adjustment, placing it between bench marks 381 and 382 , which removed errors in primary circuit from Youngstown to Struthers.

The leveling in Youngstown and Ravenna quadrangles was done in 1905 by R. C. Seitz, in Warren and Ravenna quadrangles in 1905 by W. H. Peabody, and in Ravenna quadrangle in 1903 by C. I. Shea, and in 1905 by G. M. Dimmick.

\section{RAVENNA QUADRANGLE.}

WAYLAND, NORTH ALONG HIGHWAY'S, TO WINDHAM; THENCE WEST TO SHALERSVILLE.

Wayland, in east face of northeast corner of Bethany Church; T. 3 N., R.

Feet.

$6 \mathrm{~W}$. ; aluminum tablet stamped " 964 ADJ $1903 " \ldots \ldots \ldots \ldots \ldots \ldots \ldots . . . . . .$.

Windham, 700 feet north of crossroads, in southeast corner of foundation of town hall; aluminum tablet stamped " 977 ADJ 1903".

Freedom (center), in northeast corner of foundation of church; aluminum tablet stamped "1175 ADJ 1903".

Shalersville, in northwest corner of foundation of town hall; aluminum tablet stamped " 1245 ADJ $1903 " \ldots \ldots \ldots \ldots \ldots \ldots \ldots \ldots \ldots \ldots \ldots \ldots \ldots \ldots \ldots \ldots \ldots .245 .359$

BALTIMORE AND OHIO BENCH MARK 415, NORTH TO CHARLESTOWN AND RETURN.

Charlestown station, northeast corner sec. 22 , T. 3 N., R. 7 W., 300 feet north of overhead bridge, in bridge seat at northwest corner of iron bridge over Hinkley Creek; aluminum tablet stamped "1041 ADJ 1903". 1, 041.100

BALTIMORE AND OHO BENCH MARK 415 , SOUTH ALONG HighWAY, TO ATWATER CENTER; THENCE EAST to DEERFIELD; THENCE NORTH TO WAYLAND.

Edinburg, southeast corner sec. 25, T. 2 N., R. 7 W., 300 feet north of main crossroads, in east face of northeast corner of Congregational Church; aluminum tablet stamped "1181 ADJ 1903 ".

Atwater Center, T. 1 N., R. 7 W., 300 feet south of crossroads, in northeast corner of column support of Congregational Church; aluminum tablet stamped " 1165 ADJ 1903 "............................ 1, 164.736

Deerfield, northeast corner sec. 32 , T. 1 N., R. 6 W., in north face of northeast corner of M. E. Church; aluminum tablet stamped "1072 ADJ 1903". 1,072. 477

Palmyra, northwest corner sec. 25 , T. $2 . N$., R. 6 W., in west face of stone guide post at center of crossroads; aluminum tablet stamped " $1037 \mathrm{ADJ}$

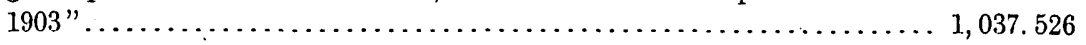

ATWATER, WEST ALONG HIGHWAY, TO RANDOLPH AND RETURN.

Randolph, at northeast corner of square, at southwest corner of post-office building, in south face of foundation; bronze tablet stamped " 1153 CLEVELAND 1903" ............................... 1, 154. 138 
RAVENNA, SOUTH ALONG HIGHWAY, TO RANDOLPH.

Feet.

Ravenna, at main entrance to court-house, in stone floor at southeast corner of veranda; bronze tablet stamped "1140 CLEVELAND 1903".... 1, 140. 164

Rootstown, on west side at southwest corner of post-office building, in face of stone foundation wall; bronze tablet stamped "1126 CLEVELAND 1903" $a$ 1, 126 . 1'09

WARREN QUADRANGLE.

NEWTON FALLS, NORTH TO BRACEVILLE; THENCE WEST TO WINDHAM.

Newton Falls, southeast corner of high-school building, in water table over basement window facing east; aluminum tablet stamped " 927 ADJ

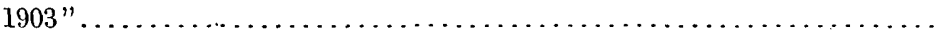

Braceville, crossing at station; top of rail.................... 909.2

NEWTON FALLS, SOUTH ALONG HIGHWAY, TO BERLIN CENTER; THENCE EAST TO CANFIELD; THENCE NORTH TO WEST AUSTINTOWN; THENCE WEST TO JACKSON CENTER; THENCE NORTH TO LORDSTOWN; THENCE EAST TO NILES.

Pricetown, 200 feet east of crossroads, in south face of southeast corner of Methodist Church; aluminum tablet stamped " 942 ADJ 1903 "........

Berlin Center, 4 miles north of, 3 miles west of Rosemont, 400 feet west of northwest corner of crossroads, in south face of southeast corner of barn of Charles Smith; aluminum tablet stamped "1023 ADJ 1903"........ 1, 022.786

Berlin Center, 450 feet east of crossroads, on south side of road, in stone doorsill to main entrance to M. E. Church; aluminum tablet stamped "1075 ADJ 1903"

942.163

Berlin Center, 2.5 miles east of, 2.5 miles west of Ellsworth, inside of fence at northeast corner of crossroads; iron post stamped "1159 ADJ 1903" (prim. trav. sta. No. 39) ............................... 1, 159. 304

Ellsworth (center), at southeast corner of Presbyterian Church, in top of stone platform to entrance; aluminum tablet stamped "1068 ADJ 1903". 1, 068.057

Canfield, in south face of southeast corner of Presbyterian Church; alumi-

- num tablet stamped "1162 ADJ 1903 "....................... 1, 162.238

Canfield, 2 feet west of band stand in park in center of town; iron post stamped "Prim. Trav. Sta. No. 143" ...................... 1, 160. 803

West Austintown, at southwest corner of crossroads, in north face of northwest corner of United Evangelical Church; aluminum tablet stamped "1012 ADJ 1903"..................................... 1,012. 182

Jackson Center, 0.2 mile east of main crossroads, south of road, in north face of northeast corner of town house; aluminum tablet stamped " 1035

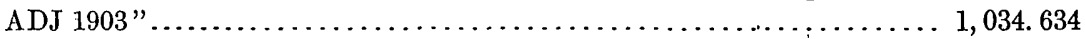

Lordstown, west side of road, 0.2 mile north of principal crossroads, in east face of northeast corner of Disciples Church, northeast corner sec. 56, T. 3 N., R. 4 W.; aluminum tablet stamped "954 ADJ 1903 ".........

Niles, sec. 5, T. 3 N., R. 3 W., at southwest corner of Main and West Church streets, in north face of northeast corner of First Presbyterian Church; aluminum tablet stamped "890 ADJ 1903".......................

AT WARREN AND LEAVITTSBURG (SET FROM BALTIMORE AND OHIO BENCH MARKS 395 AND 399).

Warren, 60 feet south of B. \& O. station, 300 feet south of Erie station, in east face of northeast corner of wholesale grocery store, in water table; aluminum tablet stamped " 880 ADJ 1903 ".

Leavittsburg, northwest corner sec. 24 , T. 4 N., R. 4 W., 400 feet west of station, northwest corner of Erie Railroad bridge over Duck Creek, in coping stone next to top; aluminum tablet stamped "895 ADJ 1903"... 


\section{YOUNGSTOWN QUADRANGLE.}

NEAR CHADWICK, SOUTH TO NILES.

Niles, 4 miles north of, 140 feet west of crossroads; primary-traverse iron post stamped "936 ADJ 1903" "Sta. No. 33"

WARREN, EAST ALONG HIGHWAY, TO BROOKFIELD AND SHARON.

Vienna, 1.5 miles west of, in north face of stone post at top of hill on north side of road; aluminum tablet stamped "1140 ADJ 1903"

Vienna, 1.5 miles east of, 3.5 miles west of Brookfield, house at northwest corner of crossroads, southeast corner, east face; aluminum tablet stamped "1180 ADJ 1903".

Vienna, 1.5 miles east of, 3.5 miles west of Brookfield, primary-traverse station 41, inside of fence, at southwest corner of crossroads; iron post stamped "1173 ADJ 1903"

Brookfield, 0.02 mile south of crossroads, in east face of southeast corner of Christian Church; aluminum tablet.stamped "1170 ADJ 1903"....... 1, 170.660

BROOKFIELD, SOUTH ALONG HIGHWAY, TO HUBBARD; THENCE WEST TO GIRARD.

Hubbard, north part of, 1,200 feet south of Lake Shore and Michigan Southern Railroad, 110 feet south of crossroads, in west wing of north abutment of iron highway bridge; aluminum tablet stamped "928 ADJ 1903".

Churchill, 2 miles east of Girard, in north face of foundation of M. E. Church; aluminum tablet stamped "1080 ADJ 1903".

Girard, in east end of east wing wall of abutment of highway bridge over Mahoning River at B. \& O. station; aluminum tablet stamped "861 ADJ $1903 "$

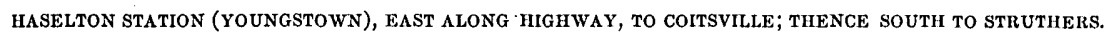

Haselton, at Andrews crossing and B. \& O. right of way, on top course of north wing wall of east abutment of bridge No. 24; aluminum tablet

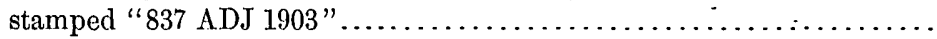

Coitsville (crossroads), in south wing wall of east abutment of iron bridge; aluminum tablet stamped "1068 ADJ 1903".

AT LOWELLVILLE (SET FROM BALTIMORE AND OHIO BENCH MARK 371).

Lowellville, in north retaining wall of dam across Mahoning River; alumi-

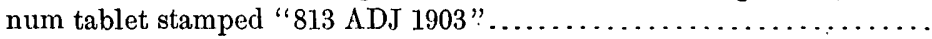

YOUNGSTOWN, SOUTHWEST ALONG HIGHWAY, TO CORNERSBURG; THENCE SOUTHEAST to BOARDMAN; THENCE EAST TO POLAND; THENCE NORTHEAST TO STRUTHERS.

Youngstown, opposite Ohio Steel Works, in west wing wall of north abutment of highway bridge across Mahoning River; aluminum tablet stamped "852 ADJ 1903".

Cornersburg, 1,050 feet south of, in west wing wall of north abutment of iron bridge over creek; aluminum tablet stamped "1037 ADJ 1903"... 1, 037. 445

Boardman, 1.6 miles west of, south end of bridge seat, west abutment of iron bridge over Mill Creek; aluminum tablet stamped "997 ADJ 1903"

Poland, in north end of west retaining wall at highway bridge over Yellow Creek; aluminum tablet stamped "1016 ADJ 1903"............... 1, 015.959 9639-Bull. 411-09-3 
COLUMBIANA AND LISBON QUADRANGLES.

COLUMBIANA AND MAHONING COUNTIES.

The leveling in Columbiana quadrangle and most of that in Lisbon quadrangle was done in 1906 by H. W. Peabody. The connections in Lisbon quadrangle with the precise lines were made in 1907 by R. C. Seitz.

COLUMBIANA QUADRANGLE.

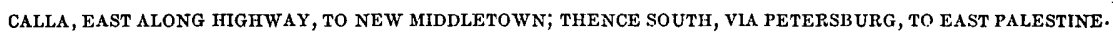

Calla, 3.5 miles east of, in east face of northeast corner of Paradise Reformed "Church, at southwest corner of crossroads; aluminum tablet stamped Feet. "1165 1906"......................................... 1, 164. 308

Calla, 6.5 miles east of, at Coalmines, 70 feet east of Youngstown and Southern Electric Railroad, in wing wall, at southwest corner of small iron bridge; aluminum tablet stamped " 1133 " ................... 1, 132.985

New Middletown, 3 miles west of, in wing wall, at southeast corner of iron bridge over branch of Yellow Creek; aluminum tablet stamped "1068". 1,068.023

New Middletown, in west face of northwest corner of school building at southeast corner of road forks at south edge of village; aluminum tablet stamped " 1257 " .................................... 1, 256.347

Petersburg, in east face of southeast corner of Presbyterian Church; aluminum tablet stamped " 1115 "............................ 1, 114.685

- Petersburg, in west part of village at road forks, on stone step to Methodist Church; chisel mark.................................... 1, 137.91

Unity, 500 feet west of northwest corner of main crossroads, in west face, 10 feet from southwest corner of Methodist Church; aluminum tablet stamped "1216 1906".

East Palestine, in north face of northwest corner of public school building on School street; aluminum tablet stamped "1027 1906" ............ 1,026.537

East Palestine, 48.8 miles west of Pittsburg, southeast corner of southeast pier, to coal tipple at state line (Pennsylvania Railroad bench mark)... 1, 033. 498

PETERSBURG, WEST, VIA COLUMBIANA, TO WASHINGTONVILLE.

New Springfield, 360 feet east of main crossroads, in center of north face of public school building, in water table; aluminum tablet stamped " 1213 $1906 "$

Columbiana, 3 miles east-northeast of, on northwest corner of $T$ road to west, in east face of southeast corner of Henry Vandel's dwelling; aluminum tablet stamped " 11431906 ".

Columbiana, southeast corner of Main and Pittsburg streets, in north face of northwest corner of M. E. Church; aluminum tablet stamped "1138

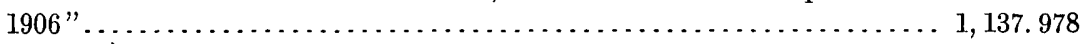

Columbiana, 2.5 miles north by 1 mile west of, southwest corner of crossroads, in east face of northeast corner of Germantown schoolhouse; aluminum tablet stamped " 11751906 " ........................ 1, 174. 762

COLUMBIANA, SOUTH TO NEAR FAIRVIEW SCHOOLHOUSE; THENCE EAST TO NEW WATERFORD.

Columbiana, southwest corner of doorsill of station, 59.61 miles west of Pittsburg; P., Ft. W. \& C. Railroad bench mark............... 1, 116. 791

Middleton, about 500 feet north of main crossroads, in south face of southeast corner of schoolhouse; aluminum tablet stamped " 12621906 "..... 1, 261. 885

New Waterford, in north face of northwest corner of public school building; aluminum tablet stamped " $10531906 " \ldots \ldots \ldots \ldots \ldots \ldots \ldots \ldots \ldots \ldots$ 1,052.770

New Waterford, northeast corner of north coping of Pennsylvania Railroad bridge; Pennsylvania Railroad bench mark................... 1,057.055 
EASt PAlestine, SOUTH ALONG highWAY, TO NEgley; THENCE WEST AND SOUTHWEST ALONG PITTSBURG, LISBON AND WESTERN RAILROAD, TO ELKTON.

Negley, 0.5 mile west of station, in bridge seat at northeast corner of P., L. \& W. Railroad bridge over Leslie Run; aluminum tablet stamped " 847 $1906 "$

Feet.

Mill Rock, 3.5 miles west of Negley, at southeast corner of railroad and highway crossing, at northwest corner of stone mill; aluminum tablet stamped "928 1906 "

846.555

Signal, 0.25 mile east of, in bridge seat at south corner of bridge over public road; aluminum tablet stamped "1069 1906".

Elkton, in bridge over Elk Run, last stone in northwest abutment; aluminum tablet stamped " 898 STBNVL" .......................

897. 694

ELKTON, NORTH TO FAIRVIEW SCHOOLHOUSE.

Elkton, 2.5 miles north of, in center of southeast face of church; aluminum tablet stamped "1153 $1906 " \ldots \ldots \ldots \ldots \ldots \ldots \ldots \ldots \ldots \ldots \ldots \ldots \ldots \ldots \ldots \ldots \ldots \ldots \ldots . .152 .492$

Fairview schoolhouse, 4 miles south of Columbiana, in east face of southeast corner; aluminum tablet stamped "1286 1906".

IISBON QUADRANGLE.

CANFIELD, SOUTH ALONG HIGHWAY, TO LEETONIA.

Calla station, 0.5 mile east of, 4 miles south of Canfield, at southeast corner of crossroads, northwest corner sec. 12, T. 16 N., R. 3 W., in west.face of northwest corner of brick schoolhouse; aluminum tablet stamped "11851906". 1, 184. 873

Locust Grove, northeast corner sec. 23, T. 16 N., R. 3 W., 1.5 miles east of Greenford, 6 miles south of Canfield, southwest corner of crossroads, in east face of northeast corner of schoolhouse; aluminum tablet stamped "1236 1906". $1,236.151$

BERLIN CENTER, SOUTHWEST TO SNODES.

Snodes, 1 mile north of northeast corner of sec. 11 , T. 18 N., R. 5 W., in east face of northeast corner of Peru schoolhouse; aluminum tablet stamped "1112 1906".

SNODES, East to Calla.

Patmos crossroads, 0.5 mile west of, at center of south side of sec. 4 , T. 17 N., R. $4^{\cdot}$ W., in south face of southeast corner of Patmos schoolhouse; aluminum tablet stamped " 12271906 "

Hickory Corners, northwest corner of sec. 7, T. 16 N., R. 3 W., at southeast corner of crossroads, in west face of northwest corner of Concord Church; aluminum tablet stamped " 10831906 "

LEETONIA, SOUTH ALONG HIGHWY AND ERIE RAILROAD, TO LISBON.

Franklin Square, 2.5 miles southwest of Leetonia, northeast corner of sec. 22 , T. 15 N., R. 3 W., 400 feet east of crossroads, in north face of northeast corner of M. E. Church; aluminum tablet stamped "1066 1906"... 1, 065.981

Teegarden, northeast of center of sec. 32 , T. 15 N., R. 3 W., in bridge seat at south west corner of small iron bridge over branch near covered bridge; aluminum tablet stamped " 9911906 ".

990.265

Coleman station, 0.5 mile south of southwest corner of sec. 9, T. $14 \mathrm{~N}$., R. $3 \mathrm{~W}$., at southeast corner of bridge seat; aluminum tablet stamped "965 1906".

Lisbon, in north face of northeast corner of court-house; bronze tablet stamped "968 STUBENVILLE"

Lisbon, south of center of sec. 14, T. 14 N., R. 3 W., diagonally opposite court-house; iron post stamped "Prim. trav. sta. No. 45 ". 
FRANKLIN SQUARE, WEST ALONG HIGHWAY, TO WESTVLLE; THENCE NORTH TO SNODES.

Salem, northeast corner of sec. 1, T. 16 N., R. 4 W., 200 feet east of Pennsylvania Railroad on south side of Main street, in south face of southeast corner of Salem Water Company pump house; aluminum tablet stamped "1169 1906".

lieet. -

Salem, 3 miles west of, near northwest corner of sec. 3, T. 16 N., R. 4 W., 2 miles east of Damascus, south side of road, in west face of northwest corner of L. K. Lightfoot's yellow brick house; aluminum tablet stamped "1247 1906"

Damascus, near southwest corner of sec. 32 , T. 17 N., R. 4 W., 2 squares northwest of main crossroads, in west face of southwest corner of school building; aluminum tablet stamped "1220 1906"................. 1, 219.064

Westville, 2 miles west of Damascus, southwest corner of sec. 36, T. 18 N., R. $5 \mathrm{~W}$., 150 feet north of crossroads and on east side of road; iron post stamped "Prim. trav. sta. No. 49 "........................... 1, 142.315

Beloit, 0.5 mile east of, northwest corner of cover stone on box culvert; P., Ft. W. \& C. Railroad bench mark......................... 1, 143.530

Beloit, 1.5 miles north of, 1.25 miles south of Snodes station, west line NW. $\frac{1}{4}$ sec. 24 , T. 18 N., R. 5 W., in west face of northwest corner of Beech Ridge schoolhouse; aluminum tablet stamped " 11651906 "........ 1, 163.884

COLEMAN STATION, WEST ALONG HIGHWAY, TO NEW ALEXANDER; THENCE NORTH TO NEAR NORTH GEORGETOWN.

Guilford, 8 miles south of Salem, near center of sec. 12, T. 15 N., R. 4 W., at west edge of village, in bridge seat at southeast corner of iron bridge over stream; aluminum tablet stamped "1116 1906"............... 1, 114.912

New Garden, north of center of sec. 9, T. 15 N., R. 4 W., 700 feet west of main crossroads and on south side of road, in west face of northwest corner of Christian Church; aluminum tablet stamped "1271 1906"......... 1,270.614

New Alexander, near southeast corner of sec. 11, T. 16 N., R. 5 W., 500 feet west by 400 feet south of main crossroads, in west face of northwest corner of Bible Christian Church; aluminum tablet stamped " 1326

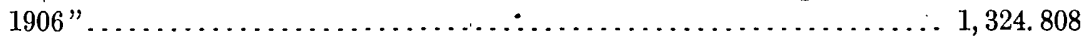

Bridgewater, near northwest corner of sec. 36 , T. 17 N., R. 5 W., 1 mile south of North Georgetown, 200 feet south of crossroads, in bridge seat at northwest corner of small iron bridge; aluminum tablet stamped "1132

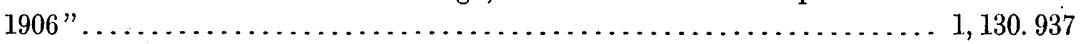

Mill school, southeast corner of sec. 14, T. 17 N., R. 5 W., east face of southeast corner of schoolhouse; aluminum tablet stamped "1110 1906 "..... 1, 109. 426

\section{ALLIANCE QUADRANGLE.}

\section{COLUMBIANA AND STARK COUNTIES.}

The leveling in Alliance quadrangle was done in 1907 by R. C. Seitz.

\section{ALLIANCE QUADRANGLE.}

ALLIANCE, NORTHWEST ALONG RAILROAD 1.4 MILES; THENCE WEST AND NORTH ALONG HighWA, TO NEW BALTIMORE.

Feet.

Alliance, Keplinger Hotel, north face of base stone at northwest corner of

building; aluminum tablet stamped " 1106 ". .................. 1, 105. 001

Crossing, Pennsylvania Railroad and Lake Erie, Alliance and Wheeling

Railroad; top of rail............................... $1,091.7$

Crossing, Lake Erie, Alliance and Wheeling Railroad and Cleveland and

Pittsburg division, Pennsylvania Railroad; top of rail. . . . . . . $1,074.9$ 
Marlboro, 3.15 miles east by 0.25 mile south of; about 200 feet west of . Feet. $T$ road south, east abutment, south bridge seat of small iron bridge, aluminum tablet stamped " $1041 "$ ".......................... 1.,040. 663

Marlboro, stone building in southwest corner of crossroads; in northeast corner of foundation; aluminum tablet stamped " 1175 "............. 1., 174. 306

ALLIANCE, NORTHEAST ALONG RAILROAD AND NORTH ALONG HIGHWAY, TO DEERFIELI\%,

Deerfield, 3.5 miles south of, near northeast corner of sec. 8 , T. 18 N., R. 5 W., 1,260 feet north of Lake Erie, Alliance and Wheeling Railroad, west wing wall of north abutment of small iron bridge; aluminum tablet stamped " 1063 ".

ALLIANCE, SOUTH ALONG CLEVELAND AND PITTSBURG DIVISION, PENNSYlVANIA RAILROAD, TO 1.42 MILES SOUTH OF MOULTRIE; THENCE EAST ALONG HIGHWAY, TO NEW ALEXANDER.

Alliance, 1.81 miles south of, along railroad right of way, 500 feet south of highway crossing, east wing wall of south abutment of culvert, in coping stone; aluminum tablet stamped " $1115 " \ldots \ldots \ldots \ldots \ldots \ldots \ldots \ldots \ldots \ldots . . \ldots \ldots . .115 .001$

Homeworth, in front of station; top of rail..................... 154. 3

Homeworth, 450 feet south of station; Cleveland and Pittsburg bridge No. 22 , east wing wall of south abutment; aluminum tablet stamped " 1147 ".. 1, 146. 665

Homeworth, 1:61 miles south of, 75 feet north of highway crossing, south abutment of Cleveland and Pittsburg bridge No. 23, east end, in coping stone; aluminum tablet stamped " 1112 "...................... 1, 111. 753

Moultrie, in front of station; top of rail........................

Moultrie, 1.42 miles south of, 1.90 miles north of Bayard Junction, north bridge seat of west abutment of small iron highway bridge 360 feet east of Cleveland and Pittsburg line; aluminum tablet stamped "1086".... 1, 085. 734

New Chambersburg, Union Church, in north face of northeast corner of foundation; aluminum tablet stamped " 1256 ".................. 1., 255. 338

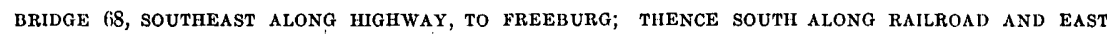
ALONG HIGHWAY, TO MOULTRIE STATION.

Alliance, 9.90 miles west of, 93 miles west of Pittsburg, northwest corner of east abutment of bridge 68 (east of Louisville); P., Ft. W. \& C. Railway; bench mark...................................... 1, 131. 642

Freeburg station, 0.1 mile west of, south wing wall of west abutment of small bridge; aluminum tablet stamped " $1196 " \ldots \ldots \ldots \ldots \ldots \ldots \ldots . ., 195.721$

Freeburg, in front of Lake Erie, Alliance and Wheeling Railroad station;

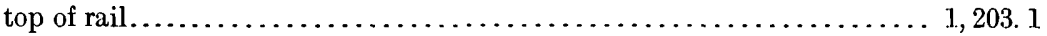

Paris, 580 feet east of station, on public highway, south abutment of stone culvert, west end of coping; aluminum tablet stamped "1150"....... 1, 149. 780

Paris, in front of station; top of rail . . . . . . . . . . . . .

Paris, 1.80 miles south of station, Mount Pleasant (district 7), school building, in south face of water table; aluminum tablet stamped "1103.8".. 1, 103. 435

Moultrie, 0.8 mile west by 1.5 miles south of, northeast corner of crossroads, south face of southwest corner of brick schoolhouse; aluminum tablet

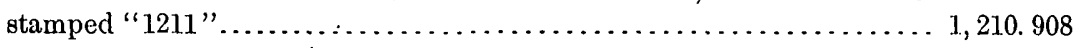

CANAL DOVER, CANTON, MASSILLON, NATARRE, AND WOOSTER QUADRANGLES.

STARK, SUMMIT, TUSCARAWAS, AND WAYNE COUNTIES.

The leveling in these quadrangles was done in 1901 by James B. Maguire, except a portion in Canal Dover quadrangle, which was . done in 1901 by $\mathrm{J}$. H. Wetzel. 


\section{CANTON QUADRANGLE.}

AT CANTON.

Canton, bridge 76, Pittsburg, Fort Wayne and Chicago Railway; railroad

Feet.

bench mark

1, 037.695

Canton, bridge 77, Pittsburg, Fort Wayne and Chicago Railway, northwest corner of east abutment of; railroad bench mark.............. 1,029. 160

Canton, southeast corner of Stark county court-house, 4.5 feet above ground; bronze tablet"stamped "1062 CANTON".................... 1, 061. 529

LOUISVILLE, SOUTHWEST ALONG HIGHWAY, VIA OSNABURG, TO NORTH INDUSTRY.

Louisville, 0.22 mile west of station, Pittsburg, Fort Wayne and Chicago Railway bridge 69 over east branch Nimishillen Creek, northwest corner of east abutment; bronze tablet stamped "1097 CANTON".......... 1, 097. 190

Osnaburg, 340 feet north of Wheeling and Lake Erie Railroad crossing, at Market street, 225 feet south of Liberty street, and 125 feet north of Walnut street, in center of east wall of culvert; bronze tablet stamped "1146 CANTON"................................. 1, 146.222

MYERSVILLE (LAKE POST-OFFICE), EAST ALONG HIGHWAY, TO HARTVILLE; THENCE SOUTH ALONG WHEELING AND LAKE ERIE RAILROAD, TO CANTON.

Hartville, on north side of station; east window sill (west end)......... 1, 164. 51

Middle Branch, Wheeling and Lake Erie Railroad station, west side of waiting room; north end of doorsill.......................... 117.45

HARTVILLE, NORTHEAST ALONG HIGHWAYS, TO NEW BALTIMORE.

New Baltimore, 0.75 mile south of, on road from New Baltimore to Louisville, bridge over branch of Deer Creek, on northeast corner of south abutment; bronze tablet stamped "1130 CANTON" (reported de-

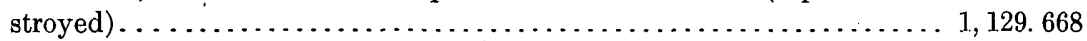

POINT 1.2 MILES SOUTH OF MIDDLE BRANCH, ALONG HIGHWAYS, TO LOUISVILLE.

Louisville, highway bridge over East Branch of Nimishillen Creek, 800 feet north of Pittsburg, Fort Wayne and Chicago Railway, on northeast corner of west wing wall of south abutment; temporary bench mark........ 1, 106. 84

\section{MASSILLON QUADRANGLE.}

POINT 2.5 MILES SOUTH OF NEW BERLIN, SOUTHWEST ALONG HighWY, TO MASSILLON.

Massillon, on stone at northwest corner of city park; bronze tablet stamped

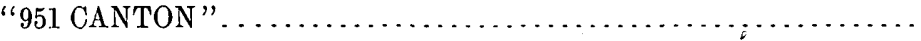

MYERSILlE, SOUTHWEST ALONG HIGHWAY, VIA NIMISILA CREEK, TO CANAL FULTON; THENCE SOUTHEAST TO MASSILLON.

Nimisila, northeast corner of crossroads, on south wall surrounding Henry

Dailey's house, in coping stone; bronze tablet stamped "1112 CANTON" 1, 111. 259

Canal Fulton, in center of north wall of stone highway bridge over Tuscarawas River; bronze tablet stamped "954 CANTON 1901"..........

MASSILLON, WEST ALONG HIGHWWY, TO DALTON; THENCE NORTH TO BURTON CITY.

Dalton, on stone at east line of Central Hotel on Main street, 1 foot inside of curb line; bronze tablet stamped "1102 CANTON"................ 1, 101. 322

BURTON CITY, NORTH ALONG HighWAY, via MARSHALLVILLE, tO EASTON; thENCE WEST tO STERLiNG.

Marshallville, northeast corner of crossroads at Union Hotel, set in brown stone post; bronze tablet stamped "1123 CANTON".............. 1, 122. 479

Easton, 400 feet west of Baltimore and Ohio Railroad, on road to Warwick, 400 feet east of its intersection with road to Doylestown, in southeast corner of west abutment of bridge; bronze tablet stamped "958 CANTON". 


\section{WOOSTER QUADRANGLE.}

STERLiNG, WEST AND SOUTH ALONG highWAY, via CANAAN, to woOster.

Sterling, 0.75 mile east of Erie Railroad station; southwest corner of east abutment of Erie Railroad bridge over creek, in bridge seat; bronze tablet stamped "964 CANTON".

Feet.

Canaan, 400 feet west of crossroads, on road from Canaan to Congress, in southeast corner of west abutment of highway bridge; bronze tablet stamped "1054 CANTON" ............................. 1, 053. 526

Madisonburg, 0.5 mile west of, at crossroads intersection, set in east wall of culvert; bronze tablet stamped "1109 CANTON".............. 1, 108. 345

Wooster University, on south side of observatory, in water table; aluminum tablet stamped "1084 CANTON" ............................ 1,083. 611

BETWEEN BURTON CITY AND WOOSTER; SPUR LINES FROM PITTSBURG, FORT WAYNE AND CHICAGo RAILWAY BENCH MARKS.

Weilersville, 1 mile east of, on the Pittsburg, Fort Wayne and Chicago Railway, on northeast corner of box culvert; railroad bench mark........ 1, 071. 326

Smithville, 1 mile southeast of, 0.8 mile north of Pittsburg, Fort Wayne and Chicago Railway, on southeast corner of north abutment of highway bridge over Sugar Creek; bronze tablet stamped "1038 CANTON".... 1, 037.855

Orrville, 1.75 miles west of, on the Pittsburg, Fort Wayne and Chicago Rail-

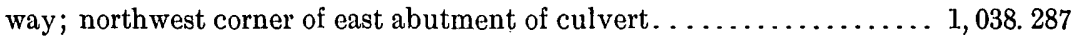

East Union, 700 feet east of Cleveland, Akron and Columbus Railway crossing of state road, on southwest corner of east abutment of highway bridge over creek; bronze tablet stamped "1074 CANTON"......... 1, 073. 149

'Orrville, Pittsburg, Fort Wayne and Chicago Railway station; gentlemen's waiting room, east end of north doorsill; railroad bench mark....... 1, 059. 594

Orrville, at front entrance of town hall, in water table; aluminum tablet stamped "1066 CANTON" ............................. 1, 064.963

\section{NAVARRE QUADRANGLE.}

MASSILLON, SOUTH ALONG WHEELING AND LAKE ERIE RAILROAD, TO POINT 2.5 MILES SOUTH OF NAVARRE.

Navarre, 0.7 mile north of station, in east end of north abutment of Wheeling and Lake Erie Railroad bridge $142 \mathrm{~A}$. (Toledo division); bronze tablet stamped "916 CANTON".

Navarre, at road crossing; top of rail

Navarre, 2.5 miles south of, on west end of pier of highway bridge over the Tuscarawas River; chisel mark.

CANAL DOVER QUADRANGLE.

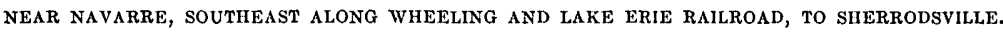

Bolivar, 0.5 mile north of station, in northeast corner of south abutment of Wheeling and Lake Erie Railroad bridge $149 \mathrm{C}$ over the Ohio Canal;

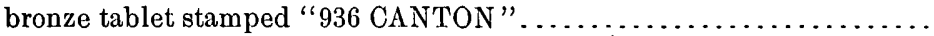

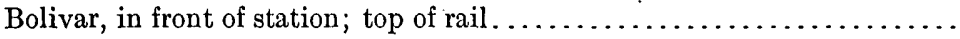

Zoar, 600 feet north of station, west corner of southeast abutment of iron bridge 153-D over mill race, in coping stone; aluminum tablet stamped "893 STEUBENVILLE".

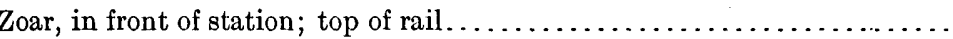

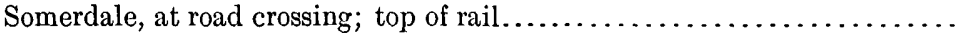

New Cumberland, 0.3 mile east of station, covered highway bridge, on northwest corner of bridge seat; bronze tablet stamped "893 STEUBENVILLE". 
MEDINA, NEW LONDON, AND WELLINGTON QUADRANGLES.

ASHLAND, HURON, MEDINA, AND LORAIN COUNTIES.

The leveling in Medina quadrangle was done in 1901 by J. B. Maguire, in 1904 by E. I. Shea and C. R. Harvey, and in 1905 by G. M. Dimmick; in Wellington quadrangle in 1904 by C. R. Harvey; and in Wellington and New London quadrangles in 1905 by G. M. Dimmick.

MẸDINA QUADRANGLE.

SEVILLE, WEST ALONG HIGHWAY, TO LODI.

Seville, southeast abutment of highway bridge over Chippewa ditch; aluminum tablet stamped " 988 CANTON".

Feet.

988.478

Seville, 5.75 miles west of; in northwest corner of northeast abutment stone of iron girder bridge over Camel Creek; aluminum tablet stamped "997 CANTON"

997.543

STERLING, NORTHWEST ALONG CLEVELAND, LORAIN AND WHEELING RAILWAY, TO GRAFTON.

Seville, 350 feet north of station, Cleveland, Lorain and Wheeling Railway bridge over creek, in northwest corner of south abutment; bronze tablet stamped "987 CANTON" $a$.

Chippewa Lake, 2,000 feet north of station, on the Cleveland, Lorain and Wheeling Railway, in south wing wall of west wall of culvert; bronze tablet stamped "1036 CANTON".

Medina, northwest corner of court-house, in water table; aluminum tablet stamped "1093 CANTON".

Lester, 1,150 feet east of, on public road, northwest corner of west abutment of highway bridge over Mallet Creek; aluminum tablet stamped "934 CANTON".

933. 620

BENNETTS CORNERS, SOUTH ALONG HIGHWAY, TO WADSWORTH.

Sherman Corners, northwest corner of crossroads in east side foundation stone at southeast corner of brick house of Dell Sherman; aluminum tablet stamped "1202 CANTON" ............................... 1, 203. 457

Weymouth, 0.7 mile north of; in east side of northeast corner of iron girder bridge over Plum Creek; aluminum tablet stamped "1032 CANTON".. 1, 032.962

Windfall, northwest corner of crossroads, in northeast corner of schoolhouse steps; aluminum tablet stamped "1195 CANTON"............... 1, 195.822

Boneta, 1 mile south of, in south side of foundation at southeast corner of schoolhouse; aluminum tablet stamped "1108 CANTON"........... 1, 109. 358

LESTER, NORTH TO LIVERPOOL; THENCE EAST TO SHERMAN CORNERS.

Liverpool, in east side of main entrance of Lutheran Church; bronze tablet stamped "Prim. Trav. Sta. No. 62814 "........................

Brunswick, in corner stone at northwest corner of west front of Methodist Church; aluminum tablet stamped "1178, CANTON"............... 1, 179. 092

SEVILLE, EAST ALONG HIGHWAY, TO WADSWORTH.

Seville, 4.75 miles east of, on abutment stone, at southwest corner of bridge. over River Styx; aluminum tablet stamped "966 CANTON"........ 964. 836

a This bench mark is to be destroyed; see first entry in this list for new bench mark. 
WELLINGTON QUADRANGLE.

BELDEN, SOUTH ALONG HIGHWAY, TO LODI.

Feet.

Litchfield, 300 feet south of square, in east wall of public schoolhouse; aluminum tablet stamped "1010 CANTON" .................... 1, 010.009

Chatham, in northeast corner of foundation of Academy Hall, public school; bronze tablet stamped "Prim. Trav. Sta. No. 23, A 1094"............. 1, 094.469

LODI, WEST ALONG BALTIMORE AND OHIO RAILROAD AND HIGHWAY, TO SULLIVAN. $a$

Lodi, at northeast corner of Taylor Inn, in stone step; bronze tablet stamped "Prim. Trav. Sta. No. 4, 927 "

Esselburn, 1 mile east of, in north side of northeast corner of stone culvert; bronze tablet stamped "946 CANTON".

Homerville, 400 feet north of square, in foundation of private residence; bronze tablet stamped " 1083 CANTON" ....................... 1, 083.843

Sullivan, in southwest corner of schoolhouse; bronze tablet stamped "Prim. Trav. Sta. 1136 CANTON" ............................. 1, 137. 443

SUlLIVAN, NORTH ALONG HIGHWAY, to WELLINGTON; THENCE NORTHEAST ALONG BIG FOUR RAILWAY AND HIGHWAY, TO BELDEN. $b$

Sullivan, 3 miles north of, 0.25 mile north of crossroad, east side of road, in top of stone culvert; bronze tablet stamped "1054 CANTON"........ 1, 055.393

Wellington, 3.75 miles south of, west side of road, 200 feet south of T road west, in top of stone culvert; bronze tablet stamped "928 CANTON". .

Wellington, in north side of Herrick Public Library; in stone foundation; bronze tablet stamped " 859 CANTON" ........................

Lagrange, in brick wall public hall facing Soldiers Monument; bronze tablet stamped "825 CANTON". (Elevation may be 1 foot greater than given.)

860.308

Belden, in northwest corner of Cleveland, Lorain and Wheeling Railway bridge over highway; bronze tablet stamped "874 CANTON" ........

873.770

NEW LONDON QUADRANGLE.

WAKEMAN, SOUTH ALONG HIGHWY, VIA CLARKSFIELD AND NEW LONDON, TO HEREFORD.

Wakeman, 1.5 miles south of, T. 4 N., R. 20 W., in south end of east face of foundation wall of residence of Mason Sheldon; aluminum tablet stamped "876 ADJ 1903"

Clarksfield, T. 3 N., R. 20 W., west end of north face of stone schoolhouse;

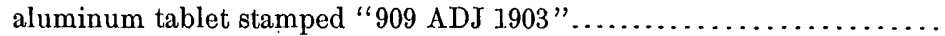

Clarksfield, 2.5 miles south by 1.5 miles east of, T. 3 N., R. 20 W., in top of bridge seat of highway bridge over East Branch Vermilion River, at - north end of east abutment; aluminum tablet stamped "901 A.DJ 1903" Clarksfield, about 4 miles south of, in T. 3 N., R. 20 W., at four corners, south end of east face, in water table of brick church; aluminum tablet stamped "934 ADJ 1903"

901. 139

New London, T. 2 N., R. 20 W., in center of north face of foundation wall of Methodist Church; aluminum tablet stamped "991 ADJ 1903".........

Hereford, west of Baltimore and Ohio Railroad station, north end of east abutment of railroad bridge 800; copper bolt; (B. \& O. B. M. 490)...... 1, 014.894

$a$ An error of 0.8 foot between Lodi and Sullivan, developed by Baltimore and Ohio and United States Coast and Geodetic Survey precise levels, is thrown between Homerville and Sullivan, the elevations at a point 1 mile east of Esselburn and at Homerville being by unadjusted line from Lodi.

$b$ This line is checked to Wellington by New London levels, but a 1-foot error between Wellington and Belden is locally adjusted south of Lagrange. 
NEW LONDON, EAST ALONG HIGHWAY, TO POINT 3 MILES NORTK OF SULLIVAN.

- New London, 6 miles east of, in T. 2 N., R. 19 W., 200 feet east of crossroads, in top of south end of east abutment of highway bridge over small stream; .aluminum tablet stamped "974 ADJ 1903".

Feet.

- Bench MaRK 6 miles East of New London, North along highwiy, to kipton.

Rochester (Station), T. 2 N., R. 19 W., in foundation wall of store of D. B. Swift; aluminum tablet stamped "934 ADJ 1903 ".

Brighton, 3.29 miles north of, T. 3 N., R. 19 W., south end of west face of town hall, in water table; aluminum tablet stamped "906 ADJ 1903"..

Brighton, 4.66 miles north of, T. 4 N., R. 19 W., in north end of east face of foundation wall of Baptist Church at four corners; aluminum tablet stamped "871 ADJ 1903"

COLLINS, SOUTH ALONG HIGHWA AND EAST ALONG RAILROAD, to CLARKSFIELD.

Collins, 2.6 miles south of, T. 4 N., R. 21 W., in foundation wall of residence of William Dabon, center of west face; aluminum tablet stamped "937 ADJ 1903"

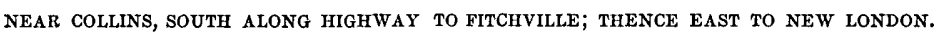

Hartland, T. 3 N., R. 21 W., 5.51 miles south of Collins, east end of north face of foundation wall of residence of W. H. Darling; tablet stamped " 946 ADJ 1903".

Hartland, 3.65 miles south of, T. 3 N., R. 21 W., 700 feet south of highway fork, in east end of north face of foundation wall of residence of $W$. W. Meade; aluminum tablet stamped "948 ADJ 1903 ".

Fitchville, T. 2 N., R. 21 W., 7.18 miles south of Hartland, in east end of south face of foundation wall of Methodist Church; aluminum tablet stamped "995 ADJ 1903 "

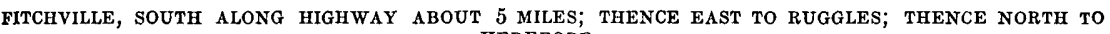
HEREFORD.

Fitchville, 4.51 miles south of, on west end of north coping of arched culvert; copper bolt (B. \& O. R. R. bench mark)................. 1, 042.458

Fitchville, 4.76 miles south of, T. 1 N., R. 21 W., in south end of west face of foundation wall of residence of W. P. Brown; aluminum tablet stamped

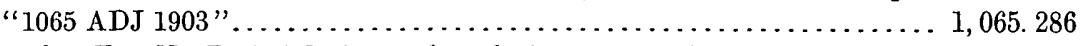

Ruggles, T. 1 N., R. 20 W., in south end of west face of foundation wall of Methodist Church; aluminum tablet stamped "1103 ADJ 1903"...... 1, 103. 566 RUGGLes, EAST along highway, to sullivan. .

Nova, 25 feet east of Baltimore and Ohio Railroad station; northeast (beveled) corner of north coping of small culvert (B. \& O. R. R. bench mark 485 A). 1, 111. 050

Nova, T. 1 N., R. 19 W., in east end of south face of foundation wall of United Brethren Church; aluminum tablet stamped "1127 ADJ 1903.". (Recovered by U. S. C. \& G. S.)............................. 1, 127. 315

ROCHESTER, EAST ALONG HIGHWAY, TO BENCH MARK 3.75 MILES SOUTH OF WELLINGTON

Rochester, 3.01 miles east of, in T. 2 N., R. 18 W., 500 feet east of 3 corners, top of north end of west abutment of highway bridge over Charlemont Creek; aluminum tablet stamped "859 ADJ 1903"..................

BRIGHTON, EAST ALONG HIGHWAY, TO WELLINGTON.

T. 3 N., Rs. 18 and 19 W., in east end of south face of foundation wall of brick schoolhouse; aluminum tablet stamped "878 ADJ 1903"........ 
ASHLAND, MANSFIRLD, PERRYVILLE, AND WEST SALEM QUADRANGLES.

ASHLAND, RICHLAND, AND WAYNE COUNTIES.

The leveling in these quadrangles was done in 1906 by R.C.Seitz.

WEST SALEM QUADRANGLE.

SULLIVAN, SOUTH 4.3 MILES; THENCE EAST ALONG HIGHWAY, VIA WEST SALEM AND AUKERMAN, TO CANAAN.

Sullivan, 4.55 miles south of, southeast corner foundation of schoolhouse;

Feet.

aluminum tablet stamped " 1147 "......................... 1, 147. 700

West Salem, 3.98 miles west of, at crossroads, southwest corner of St. Johns' -

Reformed Church; aluminum tablet stamped " $1173 " \ldots \ldots \ldots \ldots \ldots \ldots \ldots$. 1, 174, 522

West Salem, southwest corner of foundation of town hall; aluminum tablet stamped " $1119 " \ldots \ldots \ldots \ldots \ldots \ldots \ldots \ldots \ldots \ldots \ldots \ldots \ldots \ldots \ldots \ldots \ldots \ldots$. 1, 120. 256

West Salem, 2.4 miles east of, north bridge seat on west abutment of small iron bridge; aluminum tablet stamped " $1027 " \ldots \ldots \ldots \ldots \ldots \ldots \ldots \ldots . . \ldots 2,02.121$

Aukerman, 0.53 mile north of highway crossing, 2 miles south of Burbank station, north side of highway and 23 feet west of Baltimore and Ohio Railroad track, in old bridge abutment; aluminum tablet stamped " $899 "$ ".

AUKERMAN, SOUTH TO NEAR OVERTON; THENCE SOUTHWEST ALONG HIGHWAYS, TO JEROMEVILLE; THENCE NORTH TO NEAR SULLIVAN.

Armstrong station, east abutment of highway bridge on north bridge seat; aluminum tablet stamped " 887 ".

New Pittsburg, 2.25 miles east by 2.25 miles north of, 385 feet northwest of crossroads, foundation under bay window at east side of residence of Martha Pfeifer; aluminum tablet stamped " 1227 ".............. 1, 227. 302

New Pittsburg, 2.25 miles southeast of, east foundation wall of Excelsior Hall at T road south; aluminum tablet stamped " 1168 ".......... 1, 168.442

Reedsburg, 2 miles southeast of, at crossroads, in south face of foundation of residence of $\mathrm{S}$. W. Oberholtzer, at southwest corner; aluminum tablet

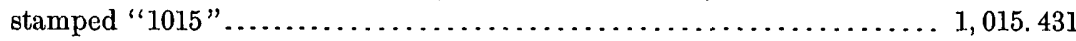

Jeromeville, 2.3 miles southeast of, 275 feet west of crossroads, north bridge seat on west abutment of small iron bridge; aluminum tablet stamped " 968 ".

Jeromeville, west foundation wall of schoolhouse; aluminum tablet stamped "1012".

Jeromeville, 3.65 miles north of, 1,200 feet south of crossroads, on west bridge seat of south abutment of small iron bridge; aluminum tablet stamped " 1041 ".

Polk, 3.12 miles south of, 430 feet south of crossroads, on west coping of stone culvert; aluminum tablet stamped "1183"..................... 1, 183.695

Polk, concrete step in front of east face of Christian Church; aluminum tablet stamped " 1276 "................................ 1, 276.505

\section{ASHLAND QUADRANGLE.}

POINT 4.3 MUES SOUTH OF SULLIVAN, WEST AND NORTH ALONG HIGHWAY, TO POINT 4.7 MILES SOUTH OP FITCHVILLE.

Savannah, 3.47 miles east of, top of north coping of stone culvert, aluminum tablet stamped " $11.36 " \ldots \ldots \ldots \ldots \ldots \ldots \ldots \ldots \ldots \ldots \ldots \ldots \ldots \ldots \ldots \ldots \ldots \ldots \ldots .1,136.463$

Savannah, east side of Methodist Church, in water table; aluminum tablet stamped "1101" .................................... 1, 101.641

Savannah, 2.30 miles west of, top of north retaining wall, top of east abutment of small iron bridge; aluminum tablet stamped " 1065 " ........ 1,065.993 
- Adario, 3.30 miles northwest of, stone culvert 300 feet south of crossroads, Feet. north end of east coping; aluminum tablet stamped " $1164 " \ldots \ldots \ldots \ldots$. 1, 165. 190

POINT 4.5 MILES EAST OF SAVANNAF, SOUTH TO ASHLAND; THENCE WEST TO OLIVESBURG; THENCE NORTH NORTHWEST TO ADARIO.

Nankin (Orange Township), 1.86 miles north of, in top of west coping of stone-arch culvert, 425 feet north of $T$ road east; aluminum tablet stamped "1088".

Nankin, 2.09 miles south of, 2.45 miles north of Ashland, north end of west abutment of concrete-arch culvert of Erie;Railroad; aluminum tablet stamped " 988 "

Ashland, in front of station; top of rail........................ 082.9

Ashland, 3 miles west of, 3.15 miles east of Olivesburg, at crossroads, east bridge seat on north abutment of small iron girder bridge; aluminum tablet stamped " $1180 " \ldots \ldots \ldots \ldots \ldots \ldots \ldots \ldots \ldots \ldots \ldots \ldots \ldots \ldots \ldots . \ldots \ldots ., 180.763$

Olivesburg, Methodist Church, south end of west foundation wall; aluminum tablet stamped " $1077 "$ ".............................. 1, 077.672

Adario, 3.40 miles north-northwest of Olivesburg,, 722 feet north of crossroads, east coping of stone culvert; aluminum tablet stamped "1152".... 1, 152.413

ASHLAND, SOUTHEAST TO NEAR HAYESVILLE; THENCE EAST TO JEROMEVILLE.

Ashland, west end of south wall of county jail; aluminum tablet stamped " $1079 "$ ".

Ashland, 3.30 miles southeast of, 4.29 miles north of Hayesville, east coping of stone culvert; aluminum tablet stamped " 1101 ".............. 1, 102. 047

NEAR HAYESVILLE, SOUTH TO HAYESVILLE; THENCE WEST ALONG HIGHWAY, TO MANSFIELD.

Hayesville, town hall at crossroads, northwest corner of foundation; bronze "tablet stamped "Prim. Trav. Sta. 1244 "..................... 1, 244. 796

Mifflin, 1.49 miles east of, 850 feet east of crossroads, north wing wall of west abutment of iron girder bridge; aluminum tablet stamped "1108"... 1, 1.08. 743

Mifflin, 0.8 mile west of, west abutment of iron girder bridge over Black Fork Mohican River, fourth course of masonry from top of south wing wall; aluminum tablet stamped " 994 ".

Mifflin, 4.2 miles west of, 3.5 miles east of Mansfield, at $T$ road south, south bridge seat on west abutment of small wooden bridge; aluminum tablet stamped " 1222 ".

MANSFIELD, NORTHEAST ALONG HIGHWAY, TO OLIVESBURG.

Windsor, 0.9 mile south of Pavonia, T road east, north bridge seat on west abutment" of small wooden bridge; aluminum tablet stamped " 1035 " ... 1, 036.055 Pavonia, Erie Railroad; top of north rail..................... 1,064. 4

Olivesburg, 3.3 miles south of, 615 feet east of crossroads, south foundation wall at west end of schoolhouse; aluminum tablet stamped " 1048 ".... 1, 049. 490

\section{MANSFIELD QUADRANGLE.}

AT MANSFIELD.

Mansfield, Park avenue crossing of Pennsylvania Railroad, east face of north end of retaining wall of bridge 153; aluminum tablet stamped " 1149 ' . . 1, 150. 391

PERRYVILLE QUADRANGLE.

MANSFIELD, SOUTHEAST TO PENNSYLVANIA RAILROAD BRIDGE 152.

Mansfield, 1.70 miles east of, northeast corner of east abutment of bridge

No. 152; chisel mark (Pennsylvania Railroad bench mark).......... 1, 139.799 
OADIZ, OARROLLTON, CLARINGTON, FLUSHING, SALINEVILLE, SOIO, ST. CLAIRSVILLE, STEUBENVILLE, UHRICHSVILLE, WELLSVILLE, AND WHEELING QUADRANGLES.

belmont, carroll, columbiana, harrison, jefferson, and monroe countibs.

The leveling in Carrollton, Wellsville, and Salineville quadrangles was done in 1902 by A. T. Bagley and R. G. DeFrees; in Steubenville quadrangle in 1901 and 1902 by J. H. Wetzel and J. A. Buford; in Cadiz, Scio, St. Clairsville, Wheeling, and Flushing quadrangles in 1901 by Mr. Wetzel and in 1902 by B. J. Green; in Clarington quadrangle in 1902 by B. J. Green and C. H. Birdseye; and in Uhrichsville quadrangle in 1902 by B. J. Green.

WELLSVILLE QUADRANGLE.

EAST LIVERPOOL, NORTH VIA CALCUTTA AND SPRUCEVALE, TO CLARKSON.

East Liverpool, large rock 28 feet wide by 35 feet long, opposite Jackson street; cut on rock (U. S. Engineer Corps bench mark 43 A) ...........

East Liverpool, in foundation stone at northwest corner of city hall; aluminum tablet stamped "731 STBNVL"........................

East Liverpool, River View Cemetery, Soldiers' Memorial Hall; bottom step at southeast corner................................ 1, 239.64

Calcutta, southeast corner of Main street, 15 feet from Trollen store, in large rock at base of telephone pole; aluminum tablet stamped "1108 STBNVL"........................................ 1, 108. 082

Clarkson, across street from Clarkson Hotel, at residence of Doctor Vale, in northwest corner of stone coping under wall; aluminum tablet stamped "1193 STBNVL".

EAST LIVERPOOL, SOUTHWEST TO WELLSVILLE; THENCE NORTHWEST, VIA WEST POINT, TO ELKTON; THENCE EAST TO CLARKSON.

Wellsville, corner Fifth and Main streets, under second window from north on east side of city hall, in top of foundation; aluminum tablet stamped

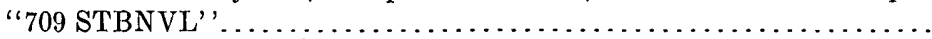

Wellsville, 3.5 miles north of, on Lisbon road, Highland town road to west; on northwest corner of front steps to Yellow Creek Presbyterian Church;

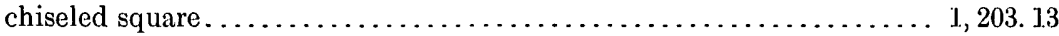

West Point, in northwest abutment of iron bridge over Beaver Creek; aluminum tablet stamped "907 STBNVL" ................... 906.148

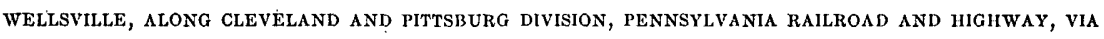
HAMMONDSVILLE, TO KNOXVILLE.

Hammondsville, northeast abutment of jron bridge on Wellsville road;

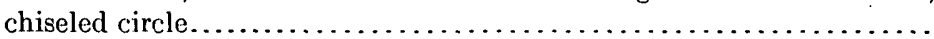

New Somerset, store (and former post-office) of N. C. Yeagley, in northeast girder stone; bronze tablet stamped "1.220 STBNVL"............ 1, 219. 364 HAMMONDSVILLE, WEST ALONG RAILROAD, TO IRONDALE.

Irondale, 400 feet south of Cleveland and Pittsburg Railroad (Pennsylvania system) track, southeast abutment of wagon bridge over North Fork Yellow Creek; bronze tablet stamped "717 STBNVL"

SALINEVILLE QUADRANGLE.

IRONDALE, NORTHWEST ALONG PENNSYLVANIA RAILROAD, TO KENSINGTON.

Irondale, 7.15 miles north west of, 50 feet east of wagon road, 1,000 feet west of coal tipple, in southeast abutment of railroad bridge 41 ; chiseled circle. . 
Kensington triangulation station, 1 mile southeast of Kensington, in top of Feet. marble post; bronze tablet stamped "1375 STBNVL" .............. 1, 375. 302

KENSINGTON, EAST ALONG ROAD, VIA LISBON, TO ELKTON.

Hanover, in northwest abutment of iron bridge over abandoned sandy canal; chiseled circle...................................... 1, 134. 05

Dungannon, in front step of St. Phillip's Catholic Church; chiseled circle. . 1, 171. 29

Dungannon, 2 miles east of, in second step of Point Pleasant M. E. Church;

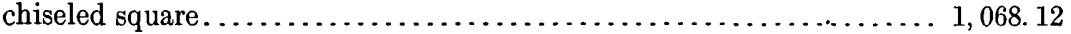

SALINEVILLE, SOUTH, VIA BEREA CHURCH, TO BERQGHOLZ.

Monroeville, 0.5 mile south of, at Elder triangulation station, bronze tablet stamped "1388 STBNVL"............................... 1, 387.432

Monroeville, 2.8 miles south of, west side of road; top of county-line monument (Jefferson and Carroll counties)......................... 1, 204. 35

Bergholz, in southeast corner of foundation of schoolhouse; bronze tablet

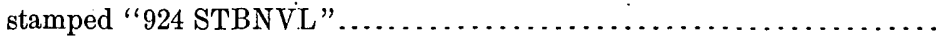

924.206

BERGHOLZ, WEST ALONG HIGHWA, TO HARLEM SPRINGS.

Morgan Bridge, 2 miles west of, on Bergholz-Harlem road, 0.5 mile west of large brick house, in northwest wing wall of iron bridge; chiseled circle. .

Morgan Bridge, 2.5 miles west of, on Bergholz-Harlem road, 510 feet east of brick house at bend of road, in stone wall of iron bridge; chiseled circle. Morgan Bridge, 4.3 miles west of, 500 feet west of forks of road northwest to Carrollton, on northwest wing wall of iron bridge on road to Kilgore; bronze tablet stamped " 958 STBNVL".

Morgan Bridge, 5 miles west of, 2 miles east of Harlem Springs, on center fork of road, 0.5 mile southeast of forks, on southwest wall of iron bridge; chiseled circle.

Harlem Springs, 0.1 mile northeast of, 300 feet north of Bergholz road, at forks to Scroggsfield, and 0.25 mile west of road southwest to Harlem, on stone in northeast wall of wooden bridge on Scroggsfield road; chiseled circle. .

CARROLLTON TRIANGULATION STATION, EAST ALONG ROAD, VIA SCROGGSFIELD, TO BEREA CHURCH.

Scroggsfield, 1 mile east of, on Salineville road, at crossing of BergholzMechanicstown road and Lake Erie, Alliance and Wheeling Railroad, 800 feet north of creamery, 10 feet west of iron bridgè, on southwest abutment; bronze tablet stamped "1025 STBNVL"............... 1,024.216

LISBON, SOUTH ALONG ROAD, VIA GAVERS, TO SALINEVILLE.

Lisbon, 3.7 miles south of, northwest abutment of bridge over run; chiseled circle........................................... 1,031. 21

Gavers, 0.5 mile south of, road forks to west, south of crossroads; southwest abutment of iron bridge. .

Gavers, 2.5 miles south of, Salineville road, in foundation at northeast corner of Geo. Patterson's house; bronze tablet stamped "1365 STBNVL". . 1, 364. 821

CARROLLTON QUADRANGLE.

HARLEM SPRINGS, NORTH ALONG HIGHWAY, TO CARROLLTON TRIANGULATION STATION.

Harlem Springs, 3 miles north of, on Augusta road at forks of road west to Carrollton road, old log house in southwest angle of corners, in stone wall, probably of iron bridge 600 feet south of corners; circle cut ....... 1, 065. 76

Carrollton triangulation station, 2.5 miles east of Carrollton, on land of $\mathrm{Mr}$. Campbell, in top of marble post; bronze triangulation tablet stamped "1378 STBNVL". 
STEUBENVILLE QUADRANGLE.

STEUBENVILLE, NORTHWEST ALONG ROAD, VIA WINTERVILLE, TO RICHMOND.a

Steubenville, in southeast corner of court-house; aluminum tablet stamped

" 715 STBNVL" ......................................

Feet.

Winterville, in southeast corner of foundation of Winterville Church, alumi-

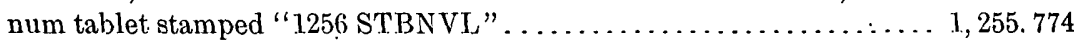

STEUBENVILLE, NORTHWEST ALONG ROAD, VIA ISLAND CREEK CHURCH, TO KNOXVILLE; THENCE SOUTHWEST TO RICHMOND.b

Alikanna, in south west pier of stone abutment of foot bridge leading to water works; aluminum tablet stamped " 663 STBNVL".................

Island Creek, 0.75 mile southeast of, in southwest pier of bridge, across Island Creek, 100 yards from road leading to Costonia; bronze tablet stamped "788 STBNVL"................................

Knoxville, at west end of, in southeast corner of stone foundation of church; aluminum tablet stamped " 1280 STBNVL" .................. 1, 279. 557

STEUBENVILle, SOUTH TO BRILLIANT; THENCE WEST, VIA NEW ALEXANDRIA, TO SMITHFIELD.C

Brilliant, at northeast abutment of railroad bridge over highway, in southeast corner of bottom tier of stone; $T$ cut in stone....................

New Alexandria, in northeast corner of stone foundation of brick church; bronze tablet stamped " 1249 STBNVL" . . . . . . . . . . . . . 1,248.789

STEUbENVILLE, WEST ALONG PITTSBURG, CINCINNATI, CHICAGO AND ST. LOUIS RAILWAY, TO REEDS MilLS.

Mingo Junction, in front of station; top of rail . . . . . . . . . . 674.5

Mingo Junction, on north west coping stone of bridge 46 ; chiseled square.... 670.21

Steubenville, 4.4 miles southwest of, on northeast corner of coping stone of

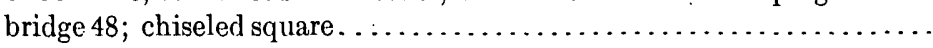

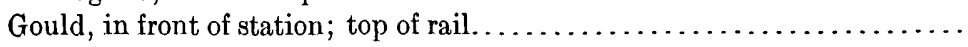

New Alexandria, in front of station; top of south rail................

New Alexandria, 0.6 mile west of, on top stone in northwest abutment of small bridge; bronze tablet stamped " 752 STEUBENVILLE".......

Fernwood, 600 feet east of station; on north end of arch culvert; railroad

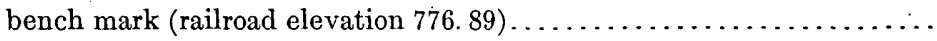

Fernwood, 1.6 miles west of station, bridge 52 over Cross Creek, on northeast corner of coping stone; railroad bench mark (railroad elevation 810.41.).

Reeds Mills, 390 feet east of station, arch bridge 53 over Cross Creek, on northeast coping stone; railroad bench mark (railroad elevation 828. 22)..

828.66

CADIZ QUADRANGLE.

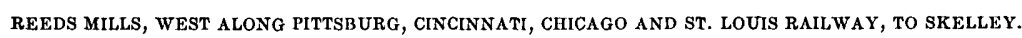

Reeds Mills, 300 feet west of station, on northeast corner of coping stone of bridge 56 ; bronze tablet stamped " 844 STEUBENVILLE". ..........

Skelley, in northwest wing wall of iron highway bridge, on top stone; chiseled square.

SKELLET, WEST ALONG RAILROAD, VIA BLOOMFIELD AND UNIONPORT, TO CADIZ JUNCTION.

Skelley, 0.9 mile west of, bridge 58 over Cross Creek, on southwest coping

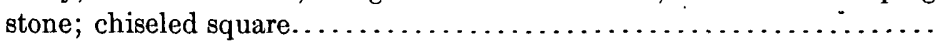

\footnotetext{
a This line closes 1 foot low on accepted elevation at Richmond; therefore elevation given for Winterville is possibly 1 foot low.

$b$ The extension of this line from Knoxville closes 1 foot low at Richmond.

c This line closes 1 foot low on accepted elevation at Smithfield; therefore the elevations are possibly 1 loot low.
} 
Unionport, road crossing; top of rail

Feet.

Unionport, 1,200 feet west of, stone bridge over Cross Creek, on northeast coping stone; aluminum tablet stamped " 976 STEUBENVILLE"....

969.2

Miller, in front of station; top of rail . . . . . . . . . . . . . . . . .

Cadiz Junction (Means post-office), road crossing; top of rail........... 1, 096.5

Cadiz Junction, at intersection of Cadiz branch line and main line of Pittsburg, Cincinnati, Chicago, and St. Louis Railway, on top stone at north side of wall on turntable; bronze tablet stamped "1099 STEUBENVILLE"

CADIZ JUNCTION, SOUTHWEST along RaILroad, to CaDiz.

Folk, road crossing at station; top of rail...................... 1,225. 2

Limestone, in front of station; top of rail...................... $1,222.6$

Conway, in front of station; top of east rail. . . . . . . . . . . . . . . .

Crawford, in front of station; top of west rail. .................. $1,263.2$

Cadiz, north entrance to court-house, on west end of first landing of stone steps; aluminum tablet stamped "1280 STEUBENVILLE" ......... 1, 279. 710

DILLONVALE, NORTH, VIA SMITHFIELD AND BLOOMFIELD, TO SKELLEY.

Smithfield, on northwest corner of water table of brick house; aluminum tablet stamped "1240 STEUBENVILLE".................. 1, 240.042

Bloomfield (Bloomingdale post-office), on northwest corner of water table of brick schoolhouse; aluminum tablet stamped "1298 STEUBENVILLE". 1, 298. 023

Cadiz JUNCtion, Via UNionvale, to cadiz.

Rexford, in front of station; top of rail . . . . . . . . . . . . . . . 3

Greenough, in front of station; top of rail. ................... 092.7

Unionvale, 2,400 feet east of station, on northwest bridge seat of bridge 193a; bronze tablet stamped "971 STEUBENVILLE" . . . . . . . . . . . . 970.989

SKELLEY, NORTH TO.RICHMOND; THENCE NORTHWEST, VIA EAST SPRINGFIELD, TO AMSTERDAM; THENCE SOUTHWEST TO JEWETT; THENCE EAST TO CADIZ JUNCTION.

Richmond, south end of, on stone doorstep of brick schoolhouse; aluminum tablet stamped " 1286 STEUBENVILLE" $a \ldots \ldots \ldots \ldots \ldots \ldots \ldots \ldots \ldots \ldots \ldots \ldots .285 .205$

East Springfield, public school building, on southeast corner of foundation stone; aluminum tablet stamped "1331. STEUBENVILLE" ....... 1,330. 583

East Springfield, 4.5 miles northwest of, on southwest wing wall of iron bridge over Yellow Creek; bronze tablet stamped "905 STEUBENVILLE".

904. 990 .

Amsterdam, 3 miles south of, north side of schoolhouse, in top foundation stone; aluminum tablet stamped "1276 STEUBEN VILLE" . . . . . . 1, 275. 500

SCIO QUADRANGLE.

AT JEWETT.

Jewett, north entrance of schoolhouse, east end of stone step; bronze tablet stamped "1009 STEUBENVILLE" ........................ 1, 008. 165

CADIZ, NORTHWEST, VIA SMITHDALE, TO STATION FIFTEEN POST:OFFICE; THENCE NORTHEAST TO BOWERSTON; THENCE NORTHWEST TO SHERRODSVILLE.

Enfield, 0.7 mile east of, north side of road at fork to north, on stone culvert;

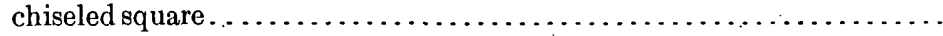

Enfield, 1.8 miles west of, on frout doorstep of John N. Haverfield's brick house; aluminum tablet stamped "938 STEUBENVILIE"........ 937.603 
Laceyville, 1.5 miles east of, 600 feet west of blacksmith shop, on southeast abutment of bridge at crossroads; chiseled square . . . . . . . . . . . . .

Smithdale, 0.7 mile west of, on southeast corner foundation stone of residence of J. W. McDivitt; aluminum tablet stamped " 909 STEUBENVILLE"

Feet.

903.61

ranklin (Tappan post-office), 2 miles west of, on northeast abutment of

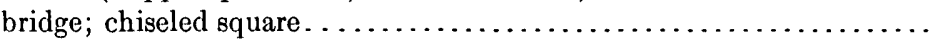

Bowerston, on northeast coping stone of Pittsburgh, Cincinnati, Chicago and St. Louis Railway bridge 84; aluminum tablet stamped " 943 STEUBEN-

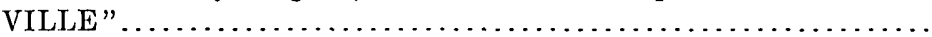

Leesville, at road crossing; top of rail. . . . . . . . . . . . . . . . . . . .

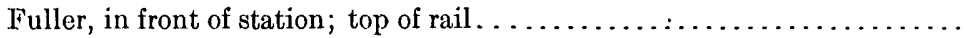

Sherrodsville, on coping stone of southeast corner of iron bridge leading from Sherrodsville to station; bronze tablet stamped "913 STEUBENVILLE".

909.488

872.99

944. 162

926.3

920.4

Sherrodsville, in front of station; top of rail .......................

915.5

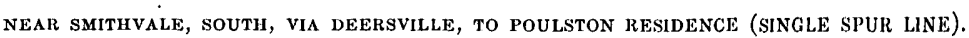

Deersville, 1.5 miles southwest of, in southeast corner of foundation of residence of J. N. and H. T. Poulston; aluminum tablet stamped "1189 STEUBENVILLE" . . . . . . . . . . . . . . . . . . . . . . . 189. 414

CONOTTON, NORTHEAST ALONG PUBLIC ROADS, TO PERRYVILLE (DOUBLE SPUR LINE).

Perryville (Lamartine post-office), near northeast corner of M. E. Church, on south foundation wall; aluminum tablet stamped "1272 STEUBEN-

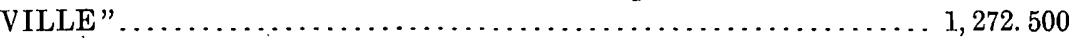

.TIPPECANOE, EAST TO NEAR HATTONIA; THENCE SOUTH TO MINKVILLE.

Clendening, on east foundation wall of $\mathrm{E}$. D. Clendening's dwelling; bronze tablet stamped "1091 STEUBENVILLE".

Hattonia, 2 miles south of, north side of Brushy Fork, east end of top step of entrance to Barretts schoolhouse; bronze tablet stamped " 915 STEUBENVILLE"

\section{UHRICHSVILLE QUADRANGLE.}

AT STATION FIFTEEN POST-OFFiCE.

Station Fifteen post-office, Pittsburgh, Cincinnati, Chicago and St. Louis Railway, stone bridge 86, on northeast coping of northeast wing wall; aluminum tablet stamped " 868 STEUBENVILLE" . . . . . . . . . . . .

TENNETT TUNNEL, NORTH TO TIPPECANOE.

Tippecanoe, southwest corner of Daviess and Spencer streets, on north foundation wall of dwelling; bronze tablet stamped " 882 STEUBENVILLE".

TIPPECANOE, EAST ALONG ROAD, VIA MINKVILLE, TO BARRETTS IBRIDGE.

Tippecanoe, 0.8 mile east of, covered bridge over Brushy Fork, on south

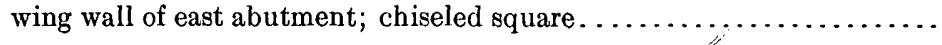

\section{WHEELING QUADRANGLE.}

SMITHFIELD, SOUTHEAST ALONG WARRENTON PIKE.

Smithfield, 5 miles east of, SW. $\frac{1}{4}$ sec. 27, T. 4 N., R. 2 W., on southeast corner of foundation of Mr. M. B. Cole's barn; aluminum tablet stamped "1214 STEUBENVILLE" 
WHEELING, ALONG CLEVELAND, LORAIN AND WHEELING RAILWA, TO BRIDGEPORT.a

Wheeling, pedestal of Wheeling and Lake Erie Railway bridge over Ohio River, on west side of Pittsburgh, Cincinnati, Chicago and St. Louis Railway, between railway and pier; center of pedestal U. S. Engineer B. M. $88 \mathrm{~A}$.

Feet.

Martins Ferry, on east side of west pier of Martins Ferry-Wheeling streetcar bridge, 6 feet north of southeast corner of pier and 1.5 feet off ground; bench mark stamped "BU $\square$ SM" . . . . . . . . . . . . . . . . . . .

Bridgeport, on coping of south side approach to Wheeling and Bridgeport bridge; bronze tablet stamped " 662 STEUBENVILLE". . . . . . . . . .

BENWOOD, W. VA., TO BELLAIRE, OHIO.

Bellaire, corner of Belmont and Thirty-second streets, on top step under transom of city building (on Belmont street); aluminum tablet stamped "667 STEUBENVILLE".

667.751

\section{ST. CLAIRSVILLE QUADRANGLE.}

UNIONVALE, SOUTHEAST TO DILLONVALE.

Adena, 1,800 feet southeast of, on top stone of northwest abutment of iron bridge 199a; aluminum tablet stamped " 860 STEUBENVILLE"......

Dillonvale, 3,300 feet north of, on southeast wing wall of iron wagon bridge at intersection of roads; aluminum tablet stamped "737 STEUBENVILLE".

BRIDGEPORT, ALONG CLEVELAND, LORAIN AND WHEELING RAILWAY, TO BANNOCK.

Wheeling Creek, on north end of west abutment of bridge 217, on east side of

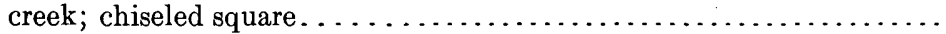

Wheeling Creek, at west end of station, on south end of west abutment of

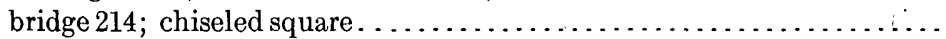

Wheeling Creek, 1 mile west of, on south end of west abutment of bridge 213 ; chiseled square . . . . . . . . . . . . . . . . . . . . . . . . . .

Wheeling Creek, 1.5 miles west of, on north end of east abutment of bridge 212 ; chiseled square . . . . . . . . . . . . . . . . . . . . . . . . .

Blaine (Pasco station), on south wall of east approach to stone bridge over Wheeling Creek on National road; chiseled square (recovered by B. \& 0 . Railroad)

661.576

Blaine, 1 mile west of, on south end of west abutment of bridge 208; tablet stamped "742 STEUBENVILLE" (recovered by B. \& O. Railroad)....

Blaine, 2.2 miles west of, 660 feet east of Barton tunnel, on south side of west abutment of bridge 203 ; chiseled square . . . . . . . . . . . . . . .

Barton, east end of, on south end of west abutment of bridge 200; chiseled square

Maynard, 1 mile east of, wooden covered county bridge over Wheeling Creek, on north side of east abutment, coping; aluminum tablet stamped "842 STEUBENVILLE" (recovered by B. \& O. Railroad)...

Maynard, 2.9 miles west of, just east of Fairpoint tunnel, on north end of

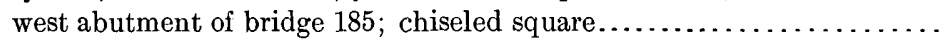

Fairpoint, 0.5 mile east of, on north end of west abutment of bridge 182; chiseled square.

841.567

888.24

900.44

Fairpoint, 0.8 mile west of, on north end of west abutment of bridge 176; aluminum tablet stamped " 920 STEUBENVILLE" (recovered by B. \&

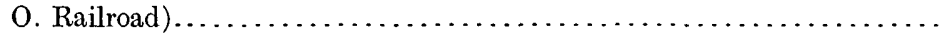

Bannock, just west of, on north end of west abutment, of bridge 170; chiseled

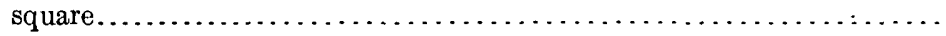


ST. CLAIRSVILLE, ALONG RAILROAD, VIA NEFFS, TO BELLAIRE.

Feet.

St. Clairsville, on east end of main entrance to court-house; bronze tablet stamped "1284 STEUBENVILLE"

North Neffs, county bridge over Little McMahon Creek, on south end of west abutment; bronze tablet stamped "733 STEUBENVILLE".

St. Clairsville Junction, just west of station, south end of east abutment of

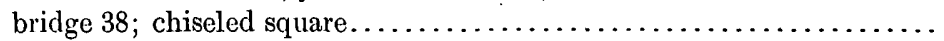

Neffs siding, 2.1 miles east of, on center of west abutment of bridge 39 ; chiseled square.

NEFFS SIDING, WEST ALONG BALTIMORE AND OHIO RAILROAD, TO BARNESVILLE.

Neffs siding, 1 mile west of, on south side of center of stone-arch bridge, on

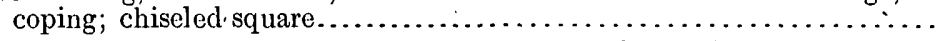

Glencoe, just east of station, on northwest corner of west abutment of bridge

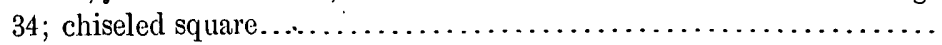

Warnock, just east of station, north end of west abutment of bridge 30 ; bronze tablet stamped "942 STEUBENVILLE".

Warnock, 1.8 miles west of, on north end of east abutment of bridge 28 , near

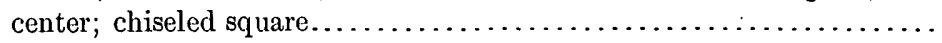

POINT 3 MLLES SOUTHEAST OF BELMONT, NORTIEAST ALONG HIGHWAY, VIA GALLOWAY KNOB, TO BALTIMORE AND OHIO RAILROAD BRIDGE 31 AT MARBLETOWN.

Galloway Knob triangulation station, 5 miles east of Belmont, in top of marble monument; bronze tablet ...................... 397.143

Marbletown, 0.12 mile north of Baltimore and Ohio Railroad, iron highway bridge, on top of stone of northwest abutment; chiseled square........

\section{FLUSHING QUADRANGLE.}

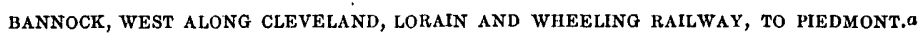

Laferty, 0.5 mile west of, on north end of west abutment of bridge 162; bronze tablet stamped. "1032 STEUBENVILLE" ............... 1,031. 892

Flushing, south side of Main street, in north foundation wall of Doctor Barricklow's dwelling; aluminum tablet stamped "1319 STEUBENVILLE". 1, 319. 380

Piedmont, just east of railroad crossing at station, on bridge seat at northwest corner of county bridge; bronze tablet stamped " 889 STEUBENVILLE".

AT BELMONT.

Belmont, on water tank at south side of the Belmont National Bank Building; aluminum tablet stamped "1188 STEUBENVILLE".......... 1, 187.457

FAIRVIEW, EAST TO HENDRYSBURG; THENCE SOUTH TO BARNESVILLE.

Fairview, on south side of Main street, on horse block in front of U. P. Church; aluminum tablet stamped "1237 STEUBENVILLE" ....... 1,237.273

Fairview, 2.3 miles east of, 1 mile west of Hendrysburg, on top of coping of south side near west end of crooked bridge; chiseled square........ 1,098.03

Hendrysburg, 1.4 miles east of, at forks of National road and pike to Barnesville, on top of stone across abutment at south end of small bridge; chiseled square.

PIEDMONT, NORTHEAST ALONG COUNTY ROADS, VIA ELK RUN, TO BRUSHY FORK ROAD NEAR MINKSVILLE.

Piedmont, 4.8 miles northeast of, 0.25 mile south of Estep, "north end of Beatty Carrother's barn, at center of wing wall to right; aluminum tablet stamped "1264 STEUBENVILLE"........................ 1,264. 097 
ELK RUN TO BARRETTS BRIDGE.

Cassville, porch on front of store building and former post-office to north of road, on stone at southeast corner; chiseled square ................. 1,246.62 CADIZ, SOUTH ALONG ROAD, TO FLUSHING.

Cadiz, 1.3 miles south of, 400 feet south of barn west of road, on bridge 25; chiseled square. $1,074.0$

\section{CLARINGTON QUADRANGLE.}

BENWOOD, SOUTHWEST ALONG OHIO RIVER AND WESTERN RAILWAY, TO KELSEY.

Weegee Creek Bridge, on southeast abutment; chiseled square........... Jacobsburg triangulation station, 0.5 mile west of Key station, Robert McKelvey's residence, in top of foundation at northeast corner of house; aluminum tablet stamped "1385 STBNVL"

KELSEY, SOUTH ALONG OHIO RIVER AND WESTERN RAILWAY ANJ PUBLIC RÓADS, VIA ARMSTRONGS MILLS AND CRABAPPLE, TO CAMERON; THENCE EAST TO GRAYSVILLE.

Armstrongs Mills, 0.12 mile east of, wagon-road bridge over Captina Creek, at northeast corner of bridge floor; square cut in stone................

Armstrongs Mills, 0.25 mile west of, on northeast corner of foundation of brick church; bronze tablet stamped " 806 STBNVL"..............

Cameron, iron bridge over Sunfish Creek, on top of stone supporting truss at west end of south abutment; bronze tablet stamped "698 STBNVL"..

Clarington, 2 miles west of, iron bridge over Nigger Run, on top stone of southwest abutment; chisel mark..........................

KELSEY, NORTHWEST ALONG HIGHWAY, TO BELMONT.

Kelsey, in front of station; top of rail

AT MYERS KNOB.

Myers Knob triangulation station, 5 miles southwest of Bellaire, in top of monument; bronze tablet................................. 359.863

DEXTER SCHOOLHOUSE (2 MILES EAST OF BEALLSVILLE), EAST ALONG GERMAN RIDGE, TO POWHATAN POINT

Beallsville triangulation station, 3 miles east of Beallsville, on top of Gale Knob, on top of marble monument; bronze triangulation tablet......... 1, 414.740

Switzer, 1 mile east of, Switzerland Township, on north side of foundation east of front entrance to German Lutheran Church; aluminum tablet stamped "1291 STBNVL".

$1,290.815$

\section{NEW MARTINSVILLE, NEW MATAMORAS, ST. MARYS, AND WOODSFIELD QUADRANGLES.}

\section{BELMONT, MONROE, AND WASHINGTON COUNTIES.}

The leveling in Woodsfield quadrangle was done in 1903 by E. O. Garvin, in New Matamoras and New Martinsville quadrangles in 1903 by R. G. De Frees, in New Martinsville quadrangle in 1903 by R. E. McFadden, and in St. Marys quadrangle in 1904 by G. L. Gordon.

\section{WOODSFIELD QUADRANGLE.}

CRABAPPLE, SOUTHWEST ALONG OHIO RIVER AND WESTERN RAILWAY, TO LEWISVILLE.

Crabapple station, southwest abutment of Ohio River and Western Railway Feet.

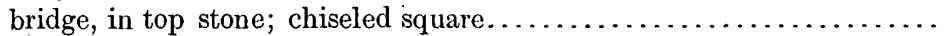

Beallsville, in west foundation of public schoolhouse, 5.5 feet north of southwest corner; aluminum tablet stamped "1262 STBNVL"............. 1, 262. 105 
Coats post-office, wagon bridge over Sunfish Creek, in top stone of southeast

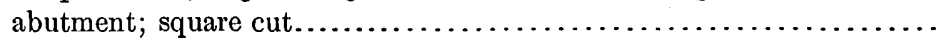

Woodsfield, in top foundation stone at southeast corner of court-house, 30 feet south of east entrance; aluminum tablet stamped "1211 STBNVL".. 1, 210.529

Lewisville, opposite Distlin Hotel, in northwest corner of Oblinger's store, 3 feet above ground; aluminum tablet stamped "1240 STBNVL"... . 1, 240. 313

Hamilton, in front of station; top of rail.................... 969.9

LEWISVILLE, NORTH ALONG HIGHWAYS, TO WIEDMANS; THENCE NORTHEAST TO SOMERTON; THENCE EAST TO ALLEDONIA.

Lewisville, 2.75 miles north of, at north edge of woods, at south doorstep of schoolhouse; chiseled square............................. $1,274.58$

Monroefield, in east corner of stone step to white schoolhouse; chiseled square................................................. 264. 67

Miltonsburg, 1.5 miles northwest of, at Wiedmans triangulation station, 0.5 mile west of Catholic Church, old cemetery north of road, on stone monument 40 by 6 by 6 inches, set 36 inches in ground; bronze tablet stamped "1394 STBNVL"................................... 1, 393.953

Malaga, at northwest corner of forks, in curb of sidewalk; chiseled square.. 1, 315. 34

NEWCASTLE, NORTH ALONG HIGHWAY, TO BRYAN; THENCE WEST TO BARNESVILLE.

Hunter, southeast corner of Christian Church, in top stone of entrance; chiseled square.

Hunter, 2 miles north of, on land owned by W. Patterson, on top of high, partly cleared hill in Goshen Township, in top of stone post 40 by 6 by 6 inches, set 33 inches in ground; bronze tablet (triangulation) stamped "1364 STBNVL"........................................ 1, 364. 085

Barnesville, city building, on west side of Arch street, on south end of second step of entrance; aluminum tablet stamped "1270 STEUBENVILLE".

SOMERTON, WEST ALONG HIGHWAY, TO TEMPERANCEVILLE; THENCE NORTH, VIA STEELE, TO BARNESVILLE.

Temperanceville, in east foundation of schoolhouse No. 10, third tier of stone from ground, 1 foot from north corner; aluminum tablet stamped "955 STBNVL".

Barnesville, 3 miles west of, at Steele triangulation station, a few feet east of Guernsey County line on a high, cleared hill in Warren County, on land owned by Isaac Steele, on top of a stone post 36 by 6 by 6 inches, set 30 inches in ground; bronze tablet stamped "1374 STBNVL"......... 1,373. 594

\section{NEW MATAMORAS QUADRANGLE.}

SYCAMORE VALLEY, EAST ALONG HIGHWAY, TO NEAR ALEXIS.

Graysville, in south foundation of house of George Crawford; bronze tablet stamped "1126 STBNVL".............................. 1, 125.606

Foraker Bridge over Little Muskingum River, on southwest abutment;

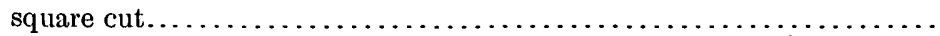

Mechanicsburg (Aitch post-office), iron bridge over Little Muskingum River, on northwest abutment; square cut.....................

Antioch, in front foundation of Christian Church; bronze tablet stamped " 1026 STBNVL"..................................... 1, 025.675

Alexis, 0.25 mile south of, at forks of road, on southwest abutment of wooden

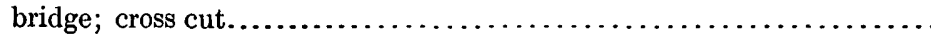


SISTERSVILLE, SOUTHWEST ALONG HIGHWAYS, VIA NEW MATAMORAS AND LAWRENCE, TO STEEL RUN.

New Matamoras, in southeast corner of foundation of school building; bronze tablet stamped "637 STBNVL".

Macabee Hill, 2 miles northeast of Ward, sec. 36 (old system), T. 3 N., R. 5 W., 0.5 mile northwest of Leith Run, 0.25 mile east of Miller's store, 150 feet west of bend in road, on hillside, north side of road, in ledge of rock; aluminum tablet stamped " 885 STBNVL".

Lawrence, 1.5 miles northeast of sec. 30 (old system), T. 3 N., R. 6 W., in northeast corner of foundation of "Goals Knob" schoolhouse (No. 3); aluminum tablet stamped "1108 STBNVL"

NEW MaRTiNSVILle QUADRANGLE.

NEAR ALEXIS, SOUTH TO SISTERSVILLE.

Alexis, 3 miles southeast of, on farm of David Yeager, 0.2 mile west of house; north side of road, in ledge of rock; aluminum tablet stamped " 969 STBNVL"

PROCTOR, W. VA., ACROSS OHIO RIVER AND UP RIVER ROAD AND OPOSSUM CREEK, TO WINKLERS MILL (SINGLE SPUR LINE).

Opossum Creek, county bridge over mouth of, at east side of south abutment;

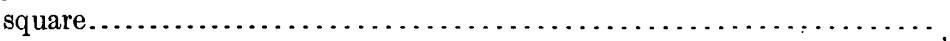

Winklers Mill, opposite Godfrey Winkler's house, county bridge over Opossum Creek, in top of north abutment, west side; bronze tablet stamped "896 GRAFTON 1903".

ST. MARYS QUADRANGLE.

AT HEAD OF CADY RUN.

Archers Fork, 2.5 miles northeast of, near center of section 11, Grandview Township, 30.8 feet from northeast corner and 30 feet from southeast corner of Bell M. E. Church; iron post stamped "1146 ADJ 1903"....... 1, 145.72i

MARIETTA AND PARKERSBURG QUADRANGLES.

WASHINGTON COUNTY.

The leveling in these quadrangles was done in 1902 by J. W. Hodges.

\author{
MARIETTA QUADRANGLE.
}

WILLOW ISLAND, W. VA., NORTHEAST, VIA NEWPORT, TO BEVAN; THENCE NORTHWEST, VIA STEEL RUN, TO POINT 3 MILES NORTH OF STANLEYVILLE; THENCE SOUTH ALONG PITTSBURG, CINCINNATI, CHICAGO AND ST. LOUIS RAILWAY, TO MARIETTA AND WILLIAMSTOWN.

Willow Island, 4 miles northeast of, 2.2 miles southwest of Newport, on southeast pier of highway bridge over Newell Run; chiseled square. . . .

Fay, 3 miles south of Steel Run post-office, southwest abutment of bridge over Bear Run, on coping stone; bronze tablet stamped "64l GRAFTON

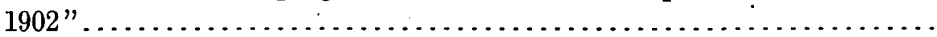

Dye, 3 miles southeast of, at forks of road, on south foundation of small

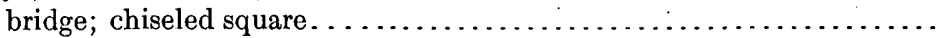

Marietta, opposite post-office, southeast corner of (new) court-house, in sill; aluminum tablet stamped "616 GRAFTON 1902"............

Feet.

606. 49

615. 730 
PARKERSBURG QUADRANGLE.

MARIETTA, WEST ALONG MaRIETTa, COLUMbUS AND CLEVELAND RAILROAD, TO DUNBAR.

Marietta, 2 miles south of, on northeast foundation of building west of Feet. track; chiseled square. . . . . . . . . . . . . . . . . . . . . . . . . .

Fleming, in north foundation of William Thomas Fleming's dwelling, 150 feet southeast of post-office and station; bronze tablet stamped "796 GRAFTON 1902".

Napier, in front of station; top of rail.

Napier station, north of track, at overhead bridge, in face of rock; bronze tablet stamped "803 GRAFTON 1902"

DUNBAR, SOUTH ALONG MHGHWAY, VIA FILLMORE, TO LITTLE HOCKING.

Dunbar, 3 miles south of, on southeast abutment of small bridge; chiseled square.

Iittle Hocking, on top of southwest abutment pier of Baltimore and Ohio Railroad bridge over Little Hocking River; bronze tablet stamped "619 GRAFTON 1902".

Little Hocking, southwest foundation of Baltimore and Ohio Railroad bridge over Little Hocking River; chiseled square.

NAPIER, NORTH ALONG HIGHWAY, TO BROWNS MILL; THENCE EAST TO WILLOW FARM.

Browns Mill, 1 mile northeast of, in foundation stone of W. J. M. Slottar's barn, near center on south side; aluminum tablet stamped " 814 GRAFTON $1902 "$

Browns Mill, 13.3 miles northeast of, on top of northwest abutment of covered highway bridge over Rainbow Creek; bronze tablet stamped " 636

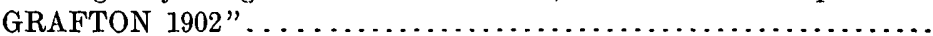

\section{MACKSBURG QUADRANGLE.}

MONROE, NOBLE, AND WASHINGTON COUNTIES.

The leveling was done in 1903 by H. G. Lowe, except on the line from Fay to Sycamore, which was run by R. G. De Frees.

\section{MACKSBURG QUADRANGLE.}

FAY, NORTH ALONG HIGHWAY, TO SYCAMORE VALLEY.

Fifteen, in north face of foundation of post-office and store building; bronze tablet stamped "704 STBNVL" . . . . . . . . . . . . . . . . . . .

Law triangulation station, 1 mile south of Lebanon, in sandstone monument on top of hill; bronze tablet stamped "1180 STBNVL".

Feet.

Sycamore Valley, 1 mile west of, T. 5 N., R. 7 W., at southeast corner of Creighton Church, in top foundation stone, 1.5 feet above ground; bronze tablet stamped "1137 STBNVL" . . . . . . . . . . . . . . . 1, 136.236

STANLEYVILLE, NORTH-NORTHWEST ALONG CLEVELAND AND MARIETTA RAILROAD, TO DUDLEY.

Stanleyville, 3.1 miles north of, 370 feet east of railroad track, north of public highway, in face of ledge of rock; bronze tablet stamped " 677 GRAFTON 1902".

Whipple, at northwest corner of Smith Brothers' store, in top of cement sidewalk; bronze tablet stamped "639 COLUMBUS"

Whipple, 2 miles north of, on top of railroad bench mark at milepost 16;

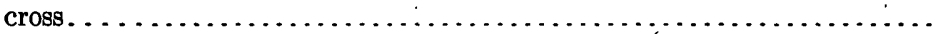

Whipple, 3 miles north of, at milepost 17 ; railroad bench mark. ....... 
Warner, 100 feet west of station, at southeast corner of store of J. D. Smith, on east side of brick foundation, 2 feet above ground; aluminum tablet

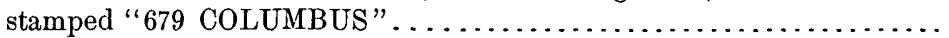

Warner, 1.36 miles north of, at milepost 19 ; railroad bench mark........ Warner, 3 miles north of, at milepost 20 ; railroad bench mark........... Warner, 4 miles north of, at milepost 21; railroad bench mark ........... Elba, high-truss iron bridge over West Fork Duck Creek, in top of abutment, at southwest corner; bronze tablet stamped "664 COLUMBUS"..

Elba, 1 mile north of, at milepost 22; railroad bench mark............ Elba, 2 miles north of, at milepost 24; railroad bench mark ............ Coffey Hill triangulation station, 90 feet in direct line from dwelling of J. O. Coffey, in square top of 6 by 6 sandstone, bronze tablet stamped "1141 COLUMBUS"

Macksburg, at southwest corner of Longfellow Hotel, on west side, in face of brick support to porch; aluminum tablet stamped " 680 COLUM-" BUS".

Macksburg, 2 miles north of, at milepost 27; railroad bench mark........ Dexter City, at southeast corner of Valley Hotel, in south face of foundation wall; aluminum tablet stamped " 691 COLUMBUS"............

Dexter City, 1.25 miles north of, road crossing of Cleveland and Marietta Railway, iron bridge over West Fork Duck Creek, in top of abutment wall at southwest corner; cross cut..........................

South Olive, at corner of North street and Center avenue, property of Wm. Kirkbrid, in top of stone at southwest corner; bronze tablet stamped "694 COLUMBUS"

South Olive, 1.25 miles north of, at milepost 30 ; railroad bench mark....

CALDWELI, SOUTHEAST ALONG PIKE, TO ASHTON; THENCE NORTHEAST, VIA FULDA, BERN, AND JERLES, TO LEWISVILLE.

Ashton, at northwiest corner of wood truss bridge over creek, in top of sandstone in foundation wall; bronze tablet stamped "785 COLUMBUS". .

Fulda, at west entrance of German Catholic Church, in top of northeast corner of sandstone doorsill; aluminum tablet stamped "1171 COLUMBUS"...

Fulda, 2 miles north of, at Fulda Hill triangulation station, in top of 6 by 6 sandstone on Bates Hill, T. 6 N., R. 8 W.; bronze tablet stamped "1250 COLUMBUS"

Bern (Carlisle), at northeast corner of high-truss iron bridge over East Fork. Duck Creek, sec. 1, T. 6 N., R. 8 W.; bronze tablet stamped " 747 COLUMBUS".

Bern, 2 miles east of, sec. 28 , T. 6 N., R. 7 W., southeast corner of iron truss bridge over Elk Fork, at road south; cross cut in top of abutment

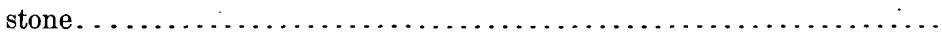

Jerles, T. 6 N., R. 7 W., in west face of foundation wall at northwest corner of. T. F. Jerles" dwelling house; bronze tablet stamped "1096 COLUMBUS".

JERLES, SOUTH TO CREIGHTON CHURCH.

Stafford, T. 6 N., R. 7 W., at southeast corner of Main and Marietta streets, in face of foundation stone of J. K. Robinson's dry goods store; aluminum tablet stamped "1081 COLUMBUS" . . . . . . . . . . . . . . 1,080. 398 
WARNER, ALONG PIKE NORTIEAST, VIA HARRIETTSVILLE, TO STAFFORD.

Lower Salem, Valley Hotel, second window from east end, in top of sandstone sill; aluminum tablet stamped " 654 COLUMBUS" ...........

Lower Salem, 2.5 miles northeast of, 'sec. 25 , T. 4 N., R. 8 W., at crossroads, at northwest corner of iron bridge over East Fork Duck Creek, in southwest corner of abutment stone; cross cut...................

Kilmer, sec. 23 , T. 5 N., R. 8 W., in top of abutment at southwest corner of covered bridge over East Fork Duck Creek; bronze tablet stamped "661 COLUMBUS".

Lower Salem, 4.75 miles northeast of, sec. 24 , T. 5. N., R. 8 W., at T road north, at southeast corner, at south end of covered bridge, in top of abut..

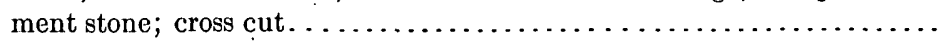

Lower Salem, 6.5 miles northeast of, at T road north, south side of covered bridge over Middle Fork Duck Creek, in top stone of east approach;

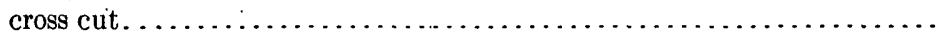

Harriettsville, at corner of Front and Church streets, northwest corner of H. A. Warnecker's store, in north face of foundation wall; aluminum tablet stamped " 672 COLUMBUS".

Harriettsville, 2.5 miles northeast of, sec. 21 , T. 5 N., R. 7 W., at T road northeast, at southeast corner of covered bridge over East Fork Duck

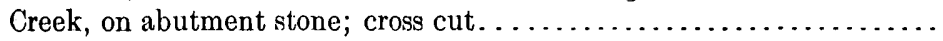

Harriettsville, 4.5 miles northeast of, sec. 23 , T. 5 N., R. 7 W., at mouth of Road Fork, covered bridge over East Fork Duck Creek, at southeast corner, in face of third stone from top of foundation wall; bronze tablet stamped "694 COLUMBUS". . . . . . . . . . . . . . . . . . . . . .

Flag post-office, sec. 24, T. 5 N., R. 7 W. (6 miles north-northeast of Harriettsville), at northwest corner of wooden truss bridge over Flag Run, in top of abutment stone; bronze tablet stamped "720 COLUMBUS"..

Feet.

653. 359

654.42

660.207

658.51

671.436

690.041

71.9. 789

HARRIETTSVLLLE, NORTH ALONG HIGHWAY, VIA ELK, TO BERN.

Elk, sec. 29 , T. 6 N., R. 8 W., in southwest corner of post-office building, in south face of top foundation stone; bronze tablet stamped "708 COLUMBUS".

ASHTON, SOUTHEAST ALONG HIGHWAY, TO HARRIETTSVILLE.

Middle Creek, sec. 6, T. 6 N., R. 8 W., south side of southwest corner of brick hotel of $\mathrm{E}$. E. Lee, in top of first foundation stone; bronze tablet stamped "713 COLUMBUS". . . . . . . . . . . . . . . . . . . .

AT KLONDYKE.

Klondyke, 0.13 mile west of, on south side of railroad, on top of concrete culvert; chiseled square, painted " 804.5 " (B. \& O. bench mark) .......

Klondyke, 0.1 mile east of, in south side of west abutment of iron bridge; aluminum tablet stamped " 808 ".

\section{ATHENS AND CHESTERHILL QUADRANGLES.}

\section{ATHENS, MORGAN, AND WASHINGTON COUNTIES.}

The leveling in Athens and Chesterhill quadrangles was done in 1903 by Wm. E. Earle and R. G. DeFrees, and in Chesterhill quadrangle in 1904 by $\mathrm{F}$. W. Hughes. 
ATHENS QUADRANGLE.

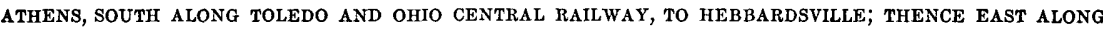
HIGHWAY, TO JUDSON; THENCE NORTH TO CANAANSVILLE.

Athens, 1.25 miles west of, on southeast end of east abutment of bridge 157

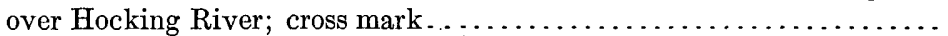

Hebbardsville, in south stone of sandstone foundation of house of E. B. Armstrong; bronze tablet stamped "730 COLUMBUS".

Feet.

730.005

Judson, in southeast corner of two-story frame schoolhouse; aluminum tablet stamped " 745 COLUMBUS".

Judson, 3 miles north of, 300 feet north of Downing's house, 100 feet southeast of large cliff on west side of creek, on southeast side of top stone of abutment of old bridge over Willow Creek; cross mark. . . . . . . . . . . BINGHAMS GAP NEAR JUDSON, NORTH TO FULTON TRIANGULATION STATION (CHECKED FLYING LEVELS).

Fulton triangulation station, on bare hogback ridge in Lodi Township, 7 miles southeast of Athens, on land owned by William Fulton, cemented in center of top of sandstone post 36 by 12 by 12 inches, dressed 8 inches square on top, set 34 inches in ground; bronze triangulation tablet

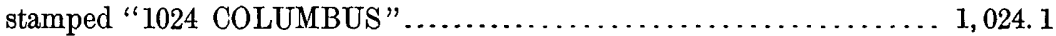

ATHENS, NORTHWEST ALONG HOCKING VALLEY RAILWAY, TO NELSONVILLE; THENCE NORTH ALONG HIGHWAY, TO OAK GROVE SCHOOLHOUSE; THENCE EAST TO BUCHTEL; THENCE NORTH TO ORBISTON; THENCE UP GOOSE RUN AND EAST TO GLOUSTER; THENCE SOUTH TO JACKSONVILLE.

Athens, in face of northwest corner stone foundation of county court-house; aluminum tablet stamped "722 COLUMBUS".

Athens, 1.2 miles northwest of, on southeast abutment of bridge over

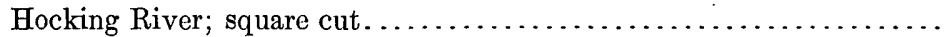

Beaumont, northwest corner of platform curb; square cut.

Nelsonville, in Fort street front of central school building; bronze tablet stamped "693 COLUMBUS".

Orbiston, 1 mile northeast of, at Goose Run coal mine, south side of road, in ledge of rock; bronze tablet stamped " 723 COLUMBUS"..........

Derthick post-office (Continental Company mines No. 10), on doorsill of brick store building; chiseled square.

756.91

ATHENS, NORTH ALONG TOLEDO AND OHIO CENTRAL RAILWAY, VIA CHAUNCEY, TO JACKSONVLLL; THENCE EAST ALONG highWAY, TO FEDERAL.

Armitage, 1.75 miles north of, on east coping of culvert, at post marked "G. B. 143"; cross mark

Armitage, 4.75 miles north of, at northeast corner of bridge over Hocking River south of Chauncey, on top stone; cross mark.................

Chauncey, in southwest corner of brick Christian Church; aluminum tablet stamped "679 COLUMBUS" Sunday Creek; bronze tablet stamped "682 COLUMBUS"............

ATHENS, WEST ALONG BALTMORE AND OHIO SOUTHWESTERN RAILROAD, TO MARSHFIELD.

Athens, northeast side of B. \& O. station, in platform; chiseled square....

Grosvenor, 2.1 miles west of, 0.5 mile east of Luhrig, on northwest abutment of railroad bridge over highway; chiseled square.

Marshfield, 200 feet west of station, in face of ledge of rock; bronze tablet stamped "822 COLUMBUS" 


\section{CHESTERHILL QUADRANGLE.}

FEDERAL, SOUTH ALONG MARIETTA, COLUMBUS AND CLEVELAND RAILROAD, TO AMESVILLE; THENCE ALONG IIGHWAY TO CANAANVILLE.

Amesville, 200 feet from railroad track, brick store of Lovel, Beasley \& Totman, in top of sandstone foundation, in south end of west wall; bronze tablet stamped " 630 COLUMBUS".

Feet.

$\Lambda$ mesville, 1 mile south of, on Athens and Amesville pike, 150 feet northeast of house and barn, on northwest stone abutment of iron bridge over creek; cross mark.

Amesville, 3 miles south of, 4.5 miles north of Canaanville, on southeast stone abutment of new iron bridge over Dutch Creek; cross............

Canaanville, 0.25 mile northwest of station, southeast corner of Methodist Church facing south, in sandstone foundation; aluminum tablet stamped " 67,5 COLUMBUS".

GUYSVILLE, SOUTH ALONG HIGHWAY, TO MILLS SCHOOLHOUSE; THENCE WEST, VIA HULL, TO BINGHAMS GAP, 1 MILE NORTH OF JUDSON.

Guysville, southwest face of foundation of house of C. C. Hulbert; bronze tablet stamped " 652 COLUMBUS 1903 " .......................

Guysville, east end of platform; head of bolt.....................

Guysville, 3.1 miles south of, 500 feet west of Mills School, at forks of road, in southwest foundation of highway bridge over stream; bronze tablet stamped "738 COLUMBUS 1903".

Rhodehaver Corners, 0.5 mile south of, forks of ridge road west to Hull, in northwest corner of; nail in base of fence post.

Rhodehaver Corners, 1.5 miles southwest of at forks of road 1 mile east of Hull (old location), at wooden bridge over East Branch Shade River, on northeast stone abutment; chiseled square:

Hull (old location), 0.5 mile west of, at byroad to south, on southeast foundation of small bridge west of forks; chiseled square.

COOLVILLE (STATION), WEST ACROSS HOCKING RIVER AND ALONG HIGHWAY, VIA DEEP HOLLOW, TO MILLS SCHOOLHOUSE, 3 MILES SOUTH OF GUYSVILLE.

Deep Hollow schoolhouse, 0.3 mile west of, at wooden bridge over Jordan Run where road turns south, on southeast foundation; chiseled square..

Mills schoolhouse, 0.1 mile west of, on Coolville-Guysville pike, at junction of road from east, on southwest abutment of bridge over stream; square cut...

DUNBAR, NORTHWEST ALONG HIGHWAY, TO CHESTERHLL; THENCE WEST TO FEDERAL,

Bartlett, in northwest face of stone foundation of house of Lewis Knapp; bronze tablet stamped " 898 COLUMBUS 1903 "...................

Bartlett, 3 miles north of, at northwest corner of wooden bridge over Coal Run, on abutment; square cut.

Chesterhill, in sill at northwest corner of foundation of school building; aluminum tablet stamped "995 COLUMBUS 1903"

Chesterhill, 3 miles west of, at forks of road west uphill to Joy, on northeast foundation of bridge over Opossum Run; square cut................

Wrightstown, in northeast corner of foundation of Christian Church; aluminum tablet stamped "1041 COLUMBUS 1903 "................... 1,040.716

BROWNS MILL, WEST ALONG HighWAY, VIA DALE, TO CHESTERHILl.

Dale (3 miles west of Wolf Creek), 4 feet south of northwest corner of foundation of store; aluminum tablet stamped " 972 ".

Chesterhill, 4 miles east of, southwest corner of Tabor Christian Church, in top stone of foundation; aluminum tablet stamped " 948 " 
ATHALIA, BIDWELL, GLENWOOD, AND POINT PLEASANT QUADRANGLES.

athens, Gallia, meigs, and lawrence counties.

The leveling in Athalia and Glenwood quadrangles and in part of Bidwell and Point Pleasant quadrangles was done in 1904 by R: S. Blinn; in part of Bidwell and Point Pleasant quadrangles in 1898 by $\mathrm{E}$. L. McNair and in 1.905 by Geo. L. Gordon.

BIDWELL QUADRANGLE.

AT VINTON.

Vinton, corner of Front and College streets, in stone sill of building; aluminum tablet stamped "612 ADJ 1903 "

Feet.

OAK HILL, VIA THURMAN, RIO GRANDE, AND RODNEY, TO GALLIPOLIS.

Thurman, in stone foundation of schoolhouse on side facing southwest; bronze tablet stamped " 696 A " ..............................

Rio Grande, north entrance to main building of Rio Grande College, in sandstone wall at right angle of steps; bronze tablet stamped " $682 \mathrm{~A}$ "......

Rodney, 2 miles east of, at front door of brick house belonging to R. B. Waddell on north side of road, in sandstone doorsill; bronze tablet stamped

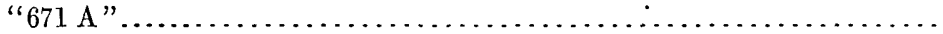

POINT 4 MILES WEST OF KYGER, SOUTHWEST TO PINEGROVE; THENCE SOUTH TO KERR.

Pinegrove, 1.9 miles northeast of, iron bridge over Campaign Creek, southeast end of northeast abutment, on bridge seat; aluminum tablet stamped "601 ADJ 1903".

Pinegrove, 1.1 miles south of, west side of culvert over small stream; aluminum tablet stamped "740 ADJ 1903 "

Evergreen, 1.1 miles south of, iron bridge over small run, east end of south abutment; aluminum tablet stamped "603 ADJ 1903"

POINT PLEASANT QUADRANGLE.

GALLIPOLIS, NORTH TO STATE EPILEPTIC HOME.

Gallipolis, at northwest corner of Gallia County jail, on water table; chiseled square (U. S. Engineer Corps precise-level bench mark 269 A)......... Gallipolis, Gallia County jail, at northwest corner west face; aluminum tablet stamped "578 ADJ 1903 ".

Gallipolis, 1.5 miles north of court-house, Ohio Epileptic Home grounds, in foundation at southwest corner of women's dining room and chapel building, third course of stone above pavement; bronze tablet stamped "606 A" ................................................

AT MIDDLEPORT.

Middleport, 3-story brick schoolhouse at corner of Fourth and Mill streets; aluminum tablet stamped "580 ADJ 1903".

GALLIPOLIS, SOUTHWEST ALONG HIGHWAY, TO THIVENER.

Gallipolis, 2.3 miles southwest of, on Mercerville pike, northwest wing wall of county bridge; bronze tablet stamped " 562 ADJ 1.903 ". 
SPILMAN, ACROSS OHIO RIVER; THENCE SOUTHWEST ALONG HIGHWAY, TO CHESHIRE; THENCE NORTHWEST TO POINT 4 MILES WEST OF KYGER.

Feet.

Cheshire, north face of stone foundation of academy at northwest corner; aluminum tablet stamped " 573 ADJ 1903 "

Cheshire, 2.5 miles northwest of, on west face of rock west of road; aluminum tablet stamped " 573 ADJ 1903 "

Kyger, 0.86 mile west of, iron bridge over Kyger Creek, top of east abutment, south end; aluminum tablet stamped "597 ADJ 1903".

596.891

Kyger, 4 miles west of, bridge over small stream, west abutment, north end; aluminum tablet stamped "707 ADJ 1.903 "

kerr, southeast along highway, to gallipolis.

Mills station, railroad crossing; top of rail.

569.9

Mills station, 0.4 mile south of, 4 miles southeast of Evergreen, iron bridge over Little Chickamauga Creek, north abutment, east end; aluminum

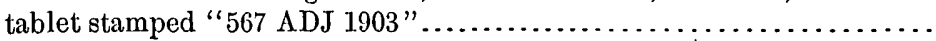

566.960

\section{GLENWOOD QUADRANGLE.}

THIVENER, SOUTH TO ANGEL.

Yellowtown (Thivener post-office), 500 feet west of blacksmith shop, on outcrop sandstone south of road; aluminum tablet stamped " 568 ADJ

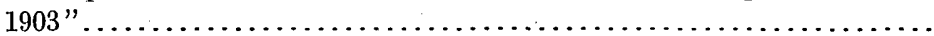

\section{ATHALIA QUADRANGLE.}

Gallipolis, southiWest along highWAy, to platform; thence southeast to miller.

Angel, 300 yards north of store, in pedestal stone supporting truss bridge over Bullskin Creek; aluminum tablet stamped " 570 ADJ 1903 "......

Leaper, 100 feet south of store, in south abutment of bridge over Bullskin Creek; aluminum tablet stamped "636 ADJ 1903".

Mercerville, at south side of store building, in stone foundation; aluminum tablet stamped "768 ADJ 1903".

Yoho, 3 miles south of, on Platform road, 600 feet south of road forks, south pedestal stone of bridge over Indian Creek; aluminum tablet stamped "653 ADJ 1903".

Platform, 3.5 miles north of, in curious-shaped rock by roadside; aluminum tablet stamped " 639 ADJ 1903 ".

Platform, 50 feet north of store and post-office, in rock outcrop; aluminum

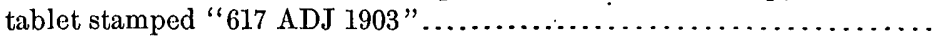

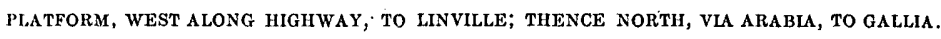

Scottown, 75 feet across road from post-office and store, in outcropping ledge of rock; aluminum tablet stamped " 602 ADJ 1903 "...............

Linville (Willowwood post-office), in rock outcrop on side hill near saltwater artesian or gas well; aluminum tablet stamped "618 ADJ 1903"..

Aid (Marion), 2 miles south of, in rock; aluminum tablet stamped "601 ADJ $1903 "$....

Aid, 2.5 feet from southeast corner of store of T. H. Neal, in sandstone bowlder; aluminum tablet stamped " 584 ADJ 1903 " $a$

Wilgus, 0.25 mile from post-office, in bowlder at west side of forks of road; aluminum tablet stamped "619 ADJ 1903"

618. 694

a At 0.035 foot greater elevation than a copper bolt in same stone, stamped " 581 I", placed there in 1897 from levels on the Ironton quadrargle. 
Arabia, 100 feet east of store, south end of bridge seat on west bridge abutment; aluminum tablet stamped " 600 ADJ 1903 ".

Waterloo, 100 feet east of covered bridge, south end of stone box culvert; aluminum tablet stamped "610 ADJ 1903"

\section{KENO, POMEROY, RAVENSWOOD, WILKESVILLE, AND ZALESKI QUADRANGLES. $a$}

ATHENS, GALLIA, HOCKING, MEIGS, AND VINTON COUNTIES.

The leveling in Ravenswood and $\mathrm{K}_{e n o}$ quadrangles was done in 1904 by F. W. Hughes; in Zaleski quadrangle in 1904 by E. C. Garvin; and in Wilkesville and Pomeroy quadrangles in 1904 by E. C. Garvin and R. S. Blinn.

\section{ZALESKI QUADRANGLE.}

MARSHFLELD, SOUTHWEST ALONG BALTIMORE AND OHIO SOUTHWESTERN RAILROAD, TO ZALESEI.

Mineral, 150 feet southwest of station, east side of street, on stone over

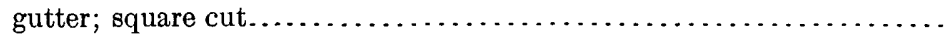

County line, between Athens and Vinton counties, north side of track; top of iron monument.

Feet.

Moonville, 50 feet from station, south side of road, in rock ledge; bronze tablet stamped "718 ADJ 1903".

709. 405

Zaleski, in northwest corner of foundation of Fisher's store; aluminum tablet stamped "741 ADJ 1903".

Zaleski, 1 mile south of, on south abutment of railroad bridge over Raccoon Creek; chiseled square (Coast and Geodetic Survey bench mark 52)...

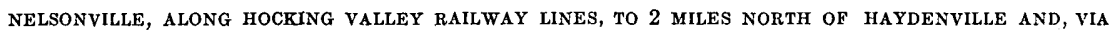
ORLAND, TO M'ARTHUR.

Nelsonville, Fort Scott Central School, in east side foundation wall, 3 feet north of steps; bronze tablet stamped "694 ADJ 1903 "..............

Haydenville, 3 miles southeast of, north side of railroad bridge over Hocking River, in top stone of west abutment; bronze tablet stamped " $690 \mathrm{ADJ}$ 1903 "'

Haydenville, in top stone of west entrance to Methodist Church; bronze

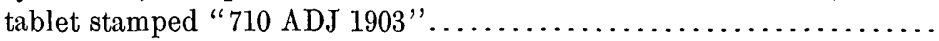

Union Furnace, 0.3 mile north of, 600 feet west of railroad crossing, in corner stone at northeast corner of brick school; aluminum tablet stamped "724 ADJ 1903".

Union Furnace, in southeast corner of foundation of United Brethren Church; bronze tablet stamped " 759 ADJ 1903 ".................

Starr, 300 feet west of, in north end of east abutment of bridge, second stone below rails; aluminum tablet stamped "776 ADJ 1903 "..........

New Plymouth, in south foundation wall of vestibule entrance to Presbyterian Church; aluminum tablet stamped " 837 ADJ 1903 "...........

Creola, 2.5 miles north of, railroad bridge 42, in top stone of south abutment, east side; aluminum tablet stamped " 752 ADJ 1903 "...........

Creola, Kirkendall's store and post-office, in top stone of south foundation wall, 7 feet from east wall and front of store; bronze tablet stamped " 760

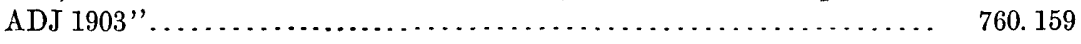


ORLAND, NORTH ALONG HIGHWAY, TO ILESBORO.

Ilesboro, in east foundation wall of Methodist Church, top stone; aluminum tablet stamped "1064 ADJ 1903".......................... 1, 064. 234

\section{WILKESVILLE QUADRANGLE.}

M'ARTHUR, SOUTH ALONG HOCKING VALLEy RAILWAY, TO DUNDAS; THENCE NORTHEAST ALONG BALTIMORE AND OHIO SOUTHWESTERN RAILROAD, TO ZALESKI.

McArthur, in north foundation wall of court-house near east end; bronze

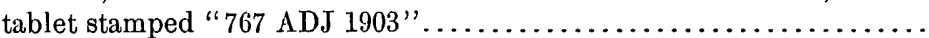

Dundas, junction of Baltimore and Ohio Southwestern Railroad and Hocking Valley Railway, 270 feet west of station, in east side top stone at south end of stone culvert on B. \& O.; bronze tablet stamped " 740

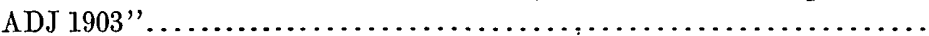

Dundas, 3 miles northeast of, in top stone of east abutment, on north side at end of railroad bridge over Elk Fork and road; aluminum tablet stamped "707 ADJ 1903".

766.733

740.266

706.686

VINTON STATION, EAST ALONG OLD STAGE ROAD, TO ALBANY.

Prattsville, in front of $\mathrm{E}$. Holden's residence, north side of road, in large sandstone; aluminum tablet stamped " 757 ADJ 1903 "..............

Albany, 6.8 miles west of, W. H. Martin's residence on south side of road, near east corner of south foundation wall; aluminum tablet stamped "704 ADJ 1903".

Albany, 4.6 miles west of, at road north, in west front foundation wall of Weaver Chapel, United Brethren Church; aluminum tablet stamped "776 ADJ 1903".

LANGSVILLE, SOUTHWEST ALONG HIGHWAYS, TO VINTON.

Danville, south side of foundation to schoolhouse; aluminum tablet stamped "781 ADJ 1903".

Rowlesville, 600 feet west of, 100 feet south of road, in natural ledge of rocks; aluminum tablet stamped " 683 ADJ 1903 ".

VINTON, NORTHWEST ALONG HOCKING VALLEY RAILWAY, TO DUNDAS; THENCE SOUTHWEST ALONG BALTIMORE AND OHO SOUTHWESTERN RAILROAD, TO HAMDEN JUNCTION.

Alice, near station, in south foundation of store building; aluminum

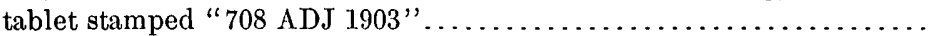

Minerton, 300 feet north of station, in south side of brick foundation of pump house; aluminum tablet stamped "628 ADJ 1903"............

Hawk, 1 mile south of station, in bridge seat on north abutment of railroad bridge over Raccoon Creek; aluminum tablet stamped "638 ADJ 1903". .

Hawk, 1 mile north of station, in face of south portal of tunnel; aluminum tablet stamped "649 ADJ 1903".

Oreton, in south portal of tunnel; aluminum tablet stamped " 694 ADJ $1903 "$

694. 488

Oreton, 3 miles north of, in cut, quarry face by railroad track; aluminum tablet stamped "775 ADJ 1903"

POMEROY QUADRANGLE.

hebBardsville, SOUth along oHo Central railway, to langsville; thence East to pomeroy.

Albany, J. H. Cline's drug store, in east wall of foundation near south end; aluminum tablet stamped " 773 ADJ 1903 ".....................

Carpenter, 1.5 miles north of, 250 feet west of railway, in northeast corner of foundation of white frame schoolhouse; bronze tablet stamped " 656 ADJ 1903" 
Carpenter, 200 feet east of railway track, in top stone at west end of north abutment of wagon bridge south of town; bronze tablet stamped " 628 ADJ 1903"

Feet.

Dyesville, wagon bridge over Leading Creek northwest of station, in east abutment at north end; aluminum tablet stamped "607 ADJ 1903"....

Dexter, 400 feet west of railroad track, in east wall of schoolhouse near north end; aluminum tablet stamped "604 ADJ 1903"..................

Langsville, 0.75 mile north of, in back wall at east end of north abutment of bridge; aluminum tablet stamped " 587 ADJ 1903 "'................

Rutland, 150 feet from railway station, in northwest corner of brick outhouse; bronze tablet stamped " 575 ADJ 1903 "....................

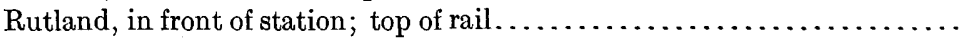

Hobson, 2.5 miles north of, in south abutment of railroad overhead crossing to public road; aluminum tablet stamped " 571 ADJ 1903 "...........

Pomeroy, in northwest corner of jail, in foundation stone, 1.72 feet below U. S. Engineer Corps bench mark $249 \mathrm{~A}$; aluminum tablet stamped "581 ADJ 1903"

627. 985

607. 082

604. 142

587. 103

573. 575

574. 6

569.173

579.403

POMEROY, NORTH ALONG HIGHWAY, TO JUDSON.

Rock Springs, 50 feet south of road crossing, in rock ledge outcrop opposite store building; aluminum tablet stamped " 652 ADJ 1903"...........

Midway (Kingsbury post-office), 400 feet north of store, on hillside in natural ledge of rock; aluminum tablet stamped " 754 ADJ 1903 "......

Millersburg, in southeast corner of foundation of schoolhouse; aluminum tablet stamped "760 ADJ 1903 ".

Burlingham, north abutment, county bridge; square cut in parapet......

Pratts Fork, 0.6 mile north of, on Judson road, in front of house, in ledge outcrop; aluminum tablet stamped "729 ADJ 1903 "'...............

at pleasanton (By athens levels).

Pleasanton, in northeast corner of sandstone foundation of Methodist Church; bronze tablet stamped " 955 COLUMBUS"'...............

BURLINGHAM, NORTHWEST ALONG HIGHWAY, TO ALBANY.

Burlingham, 1.7 miles west of, at crossroads, on natural ledge of rock; alu-

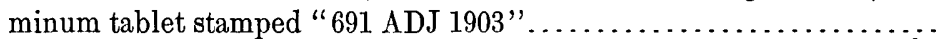

Woodyards, 4 miles east of Albany, at T road on Pagetown road, 300 feet east of white house, on parapet stone of bridge; aluminum tablet stamped "766 ADJ 1903"............................................

650.173

754. 275

758. 184

663. 071

727. 258

954.873

689.316

764. 443

\section{RAVENSWOOD QUADRANGLE.}

POMEROY, SOUTHEAST ALONG HIGHWAY, TO SYRACUSE; THENCE EAST TO SPILLER.

Syracuse, in southwest corner of foundation of public school; aluminum

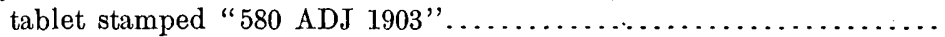

Cross's mill, 1.3 miles east of, 600 feet north of crossroads, 400 feet south of V. L. Morrison's house and sawmill, 80 feet west of center of RacineBashan road at watering trough, in bluff 10 feet north of spring; aluminum tablet stamped "656 ADJ 1903".

580.079

Spiller, 500 feet west of post-office, on stepping stone of J. W. Bush's residence; aluminum tablet stamped "710 ADJ 1903" ................

\section{KENO QUADRANGLE.}

LINE TOMEROY TO JUDSON OF POMEROY LIST.

Rock Springs, 3 miles north of, in front of Wm. Rafford's house, in outcropping ledge; aluminum tablet stamped " 681 ADJ 1903"'.......... 
SPILLER, NORTHEAST TO PORTI.AND.

Elden post-office, 290 feet south of Allen's house, 392 feet north of fork of Feet. road, in rock bluff 20 feet east from center of road; aluminum tablet

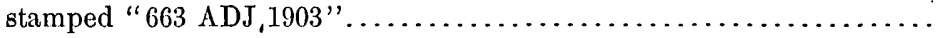

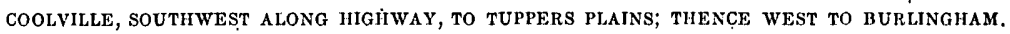

Coolville, 400 feet south of station, in face of large rock, 100 fcet south of small wooden bridge, northwest side of road; aluminum tablet stamped "603 COLUMBUS 1903" $a$

Coolville, in south side of bowlder on the main street; aluminum tablet stamped "694 ADJ 1903".

693. 800

Coolville, 2.9 miles southwest of, at Bethel schoolhouse, in southwest corner of foundation; aluminum tablet stamped "791 ADJ 1903".

Tuppers Plains, in southeast corner of foundation of schoolhouse; aluminum tablet stamped "760 ADJ 1903".

Tuppers Plains, 3.5 miles west of, at brick schoolhouse, in southeast corner of foundation; aluminum tablet stamped " 642 ADJ 1903 "..........

Alfred post-office, 2.7 miles west of, 1.25 miles east of Flora, 400 feet northeast of road forks, in bluff of rock; aluminum tablet stamped " 665 ADJ 1903 ".

664.892

GREENUP, IRONTON, JACKSON, OAKHILL, AND SCIOTO QUADRANGLES.

GALLIA, JACKSON, LAWRENCE, AND SCIOTO COUNTIES.

The descriptions in the following list are republished from Appendix to the Nineteenth Annual Report of the Director, pp. 229-242. A correction of 1.201. feet has been subtracted from the elevations previously published, excepting on line from Hamden Junction to Oakhill crossing. The Coast and Geodetic Survey elevation for bench mark LIII near Hamden was not accepted, additional connertions made in 1904 showing the bench mark to have been disturbed, probably by reconstruction of bridge. The leveling was done in 1897 and 1898, mostly by E. L. McNair; but some work in the Ironton quadrangle was done by Melville Gillett.

JACKSON QUADRANGLE.

HAMDEN JUNCTION, SOUTI ALONG BALTIMORE AND OHIO SOUTHWESTERN RAILROAD, TO BERLIN.

Hamden station, 0.5 mile east of, on coping of Baltimore and Ohio Southwestern Railroad culvert; cut (bench mark LIII of Coast and Geodetic Survey transcontinental line of precise levels) . ................. Feet.

Wellston, First National Bank building at southwest corner of Broadway and Ohio avenue, in foundation stone left corner of entrance; bronze tablet stamped "731 A".

BERLIN, SOUTH ALONG CINCINNATI, HAMILTON AND DAYTON RAILWAY, TO MADISON.

Burris, 2,000 feet west of station, 10 feet north of east and west highway, in sandstone ledge; bronze tablet stamped "702 A". 
OAKHILL QUADRANGLE.

MADISON, SOUTH ALONG CINCINNATI, HAMILTON AND DAYTON RAILWAY, TO GALLIA; THENCE SOUTHWEST TO OLIVE FURNACE; THENCE NORTHWEST ALONG HIGHWAY, TO HALÉS CREEK.

Madison, 575 feet north of station, near south end of rock cut on curve of about 8 feet west of center of track of Cincinnati, Hamilton and Dayton Railway; bronze tablet stamped " 688 A" ...................... Oakhill, Madison Township, 25 feet west of Cincinnati, Hamilton and Dayton Railway, 1.5 feet north of highway at crossing; iron post stamped "695I".

Gallia, northwest corner of store and post-office, between doors of post-office and telegraph office, north side of building, 19 feet from north west corner, in sandstone water table; bronze tablet stamped " $657 \mathrm{I}$ "...............

Greenfield, section 31, on land of Lloyd heirs, in field, 1,200 feet from house of Mrs. Jenkins, in sandstone ledge; copper bolt stamped "884 I"......

Feet.

686. 311

697.851

659.276

886.473

IIALES CREEK, NORTH TO MABEE.

Esther, 1.4 miles northeast of, 1.9 miles northeast of Monroe station on Baltimore and Ohio Southwestern Railroad, in northern half of northeast quarter section 29, Jefferson Township, 140 feet east of highway, 0.25 mile north of water tank on coal railway, in face of sandstone ledge; bronze tablet stamped " $803 \mathrm{I}$ ".

804. 773

MABEE, WEST TO BRUSHY FORK OF JITTLE SCIOTO RIVER.

Mabee, 4.5 miles west of, 120 feet northwest of schoolhouse (district No. 12), Madison Township, 225 feet east of road, 75 feet higher than road, in sandstone ledge of hillside; bronze tablet stamped " $678 \mathrm{I}$ "...........

MABEF, VIA GRAHAMSVILLE AND CAMBA, TO CIAY.

Camba, 4.3 miles west of, Freedman Church, Franklin Township, between the two front doors, set horizontally in center of foundation stone; bronze tablet stamped "739 I".

741. 757

Clay, 0.75 mile east of, on road to Madison furnace, district schoolhouse No. 3 , Madison Township, in foundation stone under southwest corner; bronze tablet stamped " 745 I"

AT HALES CREEK.

Hales Creek, on north side of road about 0.25 mile west of station and postoffice, on land of Mrs. Gertrude Kuhner, 64 feet above level of road, in extreme west end of perpendicular sandstone bluff about 50 feet high; copper bolt stamped "714 I."

SCIOTO QUADRANGLE.

HALES CREEK, SOUTHWEST, VIA SOUTH WEBSTER AND WAIT, TO SCIOTOVILLE.

Scioto furnace, 1,900 feet southwest of station, on side hill in partly wooded lot of Scioto Furnace Company, 125 feet south of and 30 feet higher than road, in sandstone bowlder; copper bolt stamped "647 I"

649.635

Sciotoville, at front doorway of two-story brick schoolhouse, in face of stone doorsill; bronze tablet stamped " 546 I" .......................

SCIOTOVILLE, NORTH, VIA SCIOTO, TO STOCKDALE.

Harrison Township, 0.5 mile south of top of hill opposite John Niner's home, in sandstone ledge 8 feet east of center of road (in narrow ravine); copper bolt stamped "788 I"

Scioto, in sandstone foundation under southwest corner of Knights of Pythias two-story building, west side of street; bronze tablet stamped "654 I" 
Scioto, 4.6 miles north of, on main pike, section 8, Madison Township, in sandstone foundation under southwest corner of Baptist Church; bronze tablet stamped " $665 \mathrm{I}$ "

STOCKDALE, EAST TO GRAHAMSVILLE.

Stockdale, in front of residence of E. V. Samson, north side of street, in stone lamp and hitching post; bronze tablet stamped "732 I".

Stockdale, 5.25 miles east of, on road to Grahamsville, 375 feet west of road crossing and small bridge over stream, Scioto Township, 7 feet north of center of road, in sloping face of sandstone ledge; bronze tablet stamped "642 I"

GREENUP QUADRANGLE.

SCIOTOVILLE, SOUTHEAST TO WHEELERSBURG.

Wheelersburg, in sandstone foundation under southwest corner of Baptist Church; bronze tablet stamped " $561 \mathrm{I}$ ".

WHEELERSBURG, EAST TOWARD CHAFFINS MILLS.

Wheelersburg, 3.2 miles east of, Porter Township, 90 feet in rear and in a line with side of district schoolhouse No. 7; copper bolt stamped "584 I".

WHEELERSBURG, SOUTH TO HAVERHILL.

Wheelersburg, 2 miles south of, at southwest corner of large iron bridge across Pine Creek, on freestone foundation; chiseled square with cross in it, thus:

Haverhill, 1.6 miles northwest of, 8 feet north of north gatepost entrance to Joshua Oakes \& Son's drain tile and red brick factory, in Green Township, Scioto County, 2.5 feet west of fence line on west of road; on top of iron post stamped "546 I"

HAVERHILL, EASTWARD TO OLD OHTO FURNACE.

Haverhill, 3.2 miles northeast of, 500 feet back of brick store, 35 feet south of road, in sandstone ledge; copper bolt stamped " $619 \mathrm{I}$ "............

$$
\text { HAVERHILL, SOUTIEAST TO IRONTON. }
$$

Haverhill, 1.6 miles southeast of, on stone monument Lawrence and Scioto counties, northeast side of road, about 300 feet southeast of brick house on

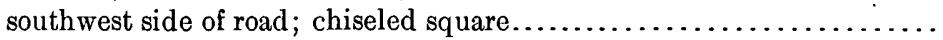

Hanging Rock, 2.6 miles northwest of, brick Ohio Baptist Church, in front of front door, in southeast corner of top step of three stone steps; copper bolt stamped " $551 \mathrm{I}$ ".......................................

\section{IRONTON QUADRANGLE.}

IRONTON, EAST TO ROCK CAMP; THENCE NORTHEAST TO AID.

Ironton, northwest corner of Fourth and Railroad streets, in southeast corner of Memorial Hall and Public Library; bronze tablet............... Hecla, on foundation stone of smokestack; copper bolt stamped "604 I".. Rock Camp, Perry Township, 100 feet northeast of Union Hall, in stone abutment of bridge over Ice Creek; copper bolt stamped "601 I"......

603. 383

AID, NORTHWARD, VIA ARABIA, TO SIERRITTS; THENCE WEST TO CAMPBELL.

Arabia, about 3 miles southwest of, T. 4 N., R. 17 W., 1,035 feet west of bridge over Symmes Creek, in large sandstone bowlder, 15 feet long; copper bolt stamped " 622 I" 
Sherritts, 0.75 mile north of, south bank of creek, 430 feet southeast of wooden truss bridge over Johns Creek, on land of H. J. Wiseman, in sandstone ledge; copper bolt stamped "614 I".

CAMPBELL, SOUTH, VIA CULBERTSON, TO HECLA.

Campbell, 0.33 mile southwest of, in sandstone foundation at northeast corner of small wooden bridge; copper bolt stamped " $687 \mathrm{I}$ "

Pedro, 0.25 mile southwest of post-office, 15 feet east of road, in solid sandstone ledge; copper bolt stamped " 622 I".

624.706

ANTRIM, OALDWELL, CAMBRIDGE, CONESVILLE, COSHOCTON, CUMBERLAND, McCONNELSVILLE, NEW COMERSTOWN, PHILO, AND SUMMERFIELD QUADRANGLES.

COShocton, GUERNSY, MONROE, MORGAN, MUSKINGUM, NOBLE, TUSCARAWAS, AND WASHINGTON COUNTIES.

The leveling was done in 1908 in Antrim, Caldwell, Cambridge, Conesville, McConnelsville, Philo, and Summerfield quadrangles by E. C. Bibbee; in Conesville, Coshocton, Cumberland, and New Comerstown quadrangles by C. H. Semper; in Caldwell, Cambridge, McConnelsville, and Philo quadrangles by H. B. Hoel; in Cumberland and Philo quadrangles by H. W. Peabody. Leveling was also done in Antrim quadrangle in 1902 by B. J. Green and in 1908 by F. H. West; and in Caldwell quadrangle in 1903 by H. G. Lowe.

\section{ANTRIM QUADRANGLE.}

POINT 1.5 MILES SOUTH OF ODELL, NORTH TO BERNICE.

Clio, 1.39 miles north of, 0.3 mile south of $Y$ roads, in foundation of west side of wagon shed owned by J. U. Marple; aluminum tablet stamped " 986 ".

Clio, 3.13 miles north of, on rock at southeast corner of $T$ road; chiseled square painted " 1110.3 "................................ 1, 109. 97

Odell, 0.43 mile south of, in stone doorstep at schoolhouse; aluminum tab-

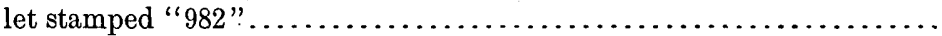

Odell, in second stone step of store owned by E. B. Kenedy; chiseled square marked " 991.4 ".

Odell, 2.34 miles north of, at $T$ road east, in north end of west side of brick

- schoolhouse; aluminum tablet stamped " 1132 ".................... 1, 131.686

Odell, 4.57 miles north of, 3 feet from well owned by T. N. Moore, on rock on east side of road; chiseled square marked " $1038.7 " \ldots \ldots \ldots \ldots \ldots \ldots 1,039.37$

Odell, 6 miles north of, 15 feet from center of public road, in south side of foundation to west end of spring house owned by Albert White; alumi-

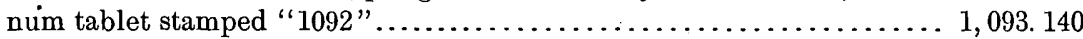

LORE CITY, NORTH TO WASHINGTON; THENCE EAST TO FAIRVIEW.

Washington, 0.56 mile south of, in south edge of east wing wall of north abutment of steel-frame bridge over creek; aluminum tablet stamped " 926 "

Washington, at southwest corner of junction of crossroads, on top of sandstone stepping block projecting 2.5 feet from ground; chiseled square marked " 1009.7 "

Elizabethtown, 0.1 mile west of, at T road north, at northeast corner of junction, on large stone at apex of angle between roads; chiseled square marked " $908.5 "$ 
Middlebourne, 2.15 miles west of, 300 yards west of T road south, 250 yards northwest of house of $\mathrm{F}$. G. Foraker, in springing stone for south retaining wall of crooked bridge (top stone to north of wall at west end); aluminum tablet stamped " 831. .".

Middlebourne, east end of town, at southwest corner of $T$ road south, in north face of square sandstone block at northwest corner of foundation to Middletown Methodist Episcopal Church; aluminum tablet stamped " $882 "$ ".

Feet.

830. 969

882. 028

Middlebourne, 3.3 miles east of, at northeast corner of stone foundation of barn south of pike; aluminum tablet stamped " 1187 "........... 1, 186. 045

Fairview, 0.85 mile west of, 30 yards east of $Y$ road, on top center stone of north retaining wall of culvert over creek, 6 inches from north and east edges of stone; chiseled square marked "1028.5" $\ldots \ldots \ldots \ldots \ldots \ldots 1,027.98$

CLIO, NORTHEAST TO LONDONDERRY.

Brady, in north edge of stone support at northeast corner of porch to stone, about 1 foot above ground; chiseled square marked " 799.4 ".

Brady, 1.68 miles east of, 0.25 mile east of crossroads, 25 yards east of $T$ road, 60 yards west of $T$ road north, in top of stone at north end of east abutment of steel-frame bridge over creek; aluminum tablet stamped " 803 "

Winterset, 1.8 miles west of, at and directly opposite $T$ road south, on stone to north of road at edge of ditch; chiseled square marked " 838.3 "..

Winterset, at northwest corner of crossroads, diagonally opposite general store, in building block 10 feet off east and north road; 10 yards off north and south road; aluminum tablet stamped " 825 ".

Winterset, 1.07 miles east of, " 20 yards west of T road north, east abutment of wooden bridge over creek, 3 and 8 inches, respectively, from sides of angle formed by south and east edges of top stone nearest bridge, on south wing wall; chiseled square marked " $828.96 " \ldots \ldots \ldots \ldots \ldots \ldots . . . . . . .$.

Antrim, west end of town, in north end of east (bottom) step to United Presbyterian Church; aluminum tablet stamped " 1001 "............. 1, 000. 823

Antrim, 2.67 miles east of, 20 yards east of $Y$ road to northeast, diagonally opposite house of J. H. Yarnell, on top stone of south wing wall of west abutment to bridge over creek; chiseled square marked " 999.1 "......

Londonderry, at northwest corner of Londonderry-Fairview and Londonderry-Freeport roads, on large flat slab; chiseled square marked "1168.8". 1, 168. 22

Londonderry, 2 miles south of, on Londonderry-Fairview road, in bridge across Skull Fork; aluminum tablet stamped " 895 "...............

ODELL, NORTHEAST TO FREEPORT.

Odell, on stone step to store; chiseled square marked " 991.3 "..........

Milnersville, west end of town, midway between T roads north and south, at schoolhouse near blacksmith shop, in second stone at south end of east abutment of bridge over Clear Fork; aluminum tablet stamped " 831 "..

Milnersville, 2.6 miles east of, between $T$ roads north and south, 500 yards northwest of schoolhouse, in second stone at north end of east abutment of bridge over creek; aluminum tablet stamped " 1000 "............

830.696

Milnersville, 5.12 miles east of, at southeast corner of crossroads, on large flat slab over east end of drain; chiseled square marked " 11.52 "....... 1., 1.51. 40

Milnersville, 6.15 miles east of, in stone lift for east door in north face of Pleasant Hill M. P. Church; aluminum tablet stamped " 1236 "...... 1, 235. 449

Freeport, 4 miles west of, at crossroads, on large stone at south end of wooden sluice; chiseled square marked " $1002.9 " \ldots \ldots \ldots \ldots \ldots \ldots \ldots 1,002.22$ 
Freeport, 2 miles west of, at southwest corner of $T$ road west, on large stone; chiseled square marked " 885.0 ".

Feet.

884. 32

Freeport, 1.5 miles west of, at $T$ road north, set horizontally in stone about 2 feet above creek, at north end of west abutment of bridge; aluminum

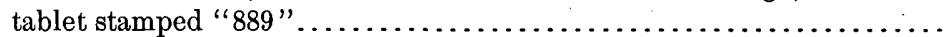

888. 125

PIEDMONT, NORTHWEST ALONG CLEVELAND, LORAIN AND WHEELING RAILWAY, TO TENNETT TUNNEL.a

Freeport, on south side of Main street, on door sill at entrance to Bank of Freeport; aluminum tablet stamped "1004 STEUBENVILLE"... 1, 004. 436

Tennett tunnel, at north end of, on top stone at northwest corner of bridge

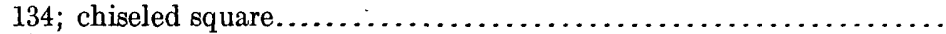

876. 51

FREEPORT, SOUTH-SOUTHEAST TO FAIRVIEW.

Freeport, 7.9 miles south of, on the Londonderry-Fairview road, on east end of south wing wall of east abutment of iron bridge over Skull Fork;

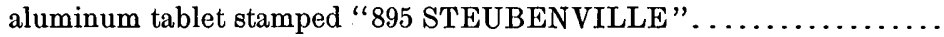

895.720

SUMMERFIELD QUADRANGLE.

KLONDYKE, VIA QUAKER CITY AND SUMMERFIELD, TO HAMILTON.

Lore. City, 0.88 mile west of, on east abutment at north side of iron bridge; chiseled square painted " 815.52 ".

815.42

Lore City, 0.55 mile east of, in north abutment of arched bridge; aluminum tablet stamped " 823 ".

Lore City, 1.63 miles east of, 35 feet north of railroad, at crossing, ori south abutment at west side of bridge; chiseled square marked " 824.05 "....

Gibson, 1.12 miles east of station, about 500 feet northeast of Catholic Church, in east abutment at north side of railroad bridge; aluminum

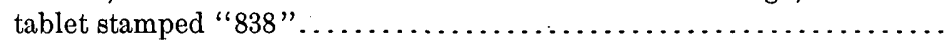

Salesville, 0.08 mile west of station, in north end of concrete culvert under railroad; aluminum tablet stamped " $852 "$ ".....................

Quaker City, 5 feet east of northeast corner of station, in top of property stone; aluminum tablet stamped " 874 "

Quaker City, 0.82 mile south of, on rock on south side of road; chiseled square painted " 1064.89 ".

823.95

837. 544

852. 207

874. 352

Batesville, 2.5 miles north of, on large rock on north side of road; chiseled square painted " 1087.97 "

Batesville, in southeast corner of foundation of high school building, 1 foot above ground; aluminum tablet stamped " 931 "

Batesville, 2.58 miles southeast of, 3,000 feet east of Jacob Wisecarver's residence, on east abutment at south side of iron bridge over Beaver Creek; aluminum tablet stamped " 842 "

841.961

Summerfield, 6.36 miles north of, 700 feet northwest of John Bates's residence, in south abutment at east side of covered bridge painted white over North Fork Wills Creek; aluminum tablet stamped " 834 "........

Summerfield, 2.91 miles north of, 260 feet north of $T$ road, in northwest corner of foundation to residence of Mrs. L. Moore; aluminum tablet stamped " 886 ".

Summerfield, in west abutment of wagon bridge over railroad, on Cross street, at east side in ninth tier of stone from top; aluminum tablet

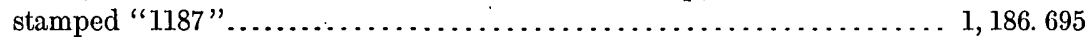

Summerfield, 1.05 miles east of, on rock south side of railroad; chiseled square marked " $1052.0 "$ "................................ 1,051. 91

$a$ Corrected to accord with Baltimore and Ohio Railroad precise-level line, adjusted. 
Ethel, 100 feet east of station, on west abutment at south side of iron bridge at railroad crossing; chiseled square painted " $917.22 " . \ldots \ldots \ldots$.

Ethel, 0.64 mile east of station, 700 feet east of residence of John Quinlin, 917. 13 65 feet west of railroad, in brownstone ledge; aluminum tablet stamped " 892 "

Herlan, in front of station; top of T rail used as post marked " 872.48 "...

Brister, 0.29 mile west of, 25 feet south of railroad at crossing, in east side of north abutment of covered bridge; aluminum tablet stamped " 894 "..

SUMMERFIELD, SOUTHWEST, VIA SARAHSVILLE, To CALDWELL.

Whigville, 60 feet south of railroad, at northwest corner of foundation of M. E. Church, 18 inches above ground; aluminum tablet stamped "1158"

Fredericksdale schoolhouse, in southeast corner of foundation, 60 feet north of railroad, 700 feet east of station; aluminum tablet stamped " 895 "....

Fredericksdale, in front of station; top of rail......................

Sarahsville, 100 feet west of old station, 35 feet east of railroad, in north side of west abutment of iron bridge; aluminum tablet stamped " 856 ". .

Duvall, 530 feet west of station, in southeast corner of foundation of schoolhouse; aluminum tablet stamped " 820 "

894. 904

882.0

856.231

820.228

MOUNT EPHRAIM, NORTH TO LORE CITY.

Mount Ephraim, in southwest corner of foundation of M. E. Church, 18 inches above ground; aluminum tablet stamped " 1147 "............ 1, 146. 472

Mount Ephraim, 2 miles north of, on east side of north abutment of covered bridge at $T$ road; chiseled square painted " 869.87 ".............

Mount Ephraim, 2.66 miles north of, on east side of north abutment of small wooden bridge; chiseled square painted " 854.77 ".............

Mount Ephraim, 3.78 miles north of, in north side of west abutment of covered bridge on T road (signpost reads "Mt. Ephraim 4 miles-Senecaville 3 miles"); aluminum tablet stamped " 835 ".

869.74

854.63

Mount Ephraim, 4.8 miles north of, on west side of south abutment of bridge in front of schoolhouse at $T$ road north; chiseled square painted "845.8".

Senecaville, in east side of north abutment of iron wagon bridge over Wills Creek; aluminum tablet stamped " 813 ".

812. 487

Senecaville, in front of station; top of rail. .......................

Lore City, 0.55 mile east of, in north abutment of concrete-arch bridge; aluminum tablet stamped " $823 "$ "............................

822. 786

CUMBERLAND QUADRANGLE.

CAMBRIDGE, SOUTH TO BELLE VALLEY.

Cambridge, south side of court-house, in top of stone steps 1 foot from

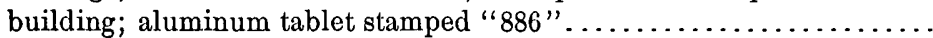

Cambridgè, 3.5 miles south of, in foundation of railroad water tank at scale house; aluminum tablet stamped " 803 "...................

Byesville, 100 feet west of railroad, in front face at southeast corner of Burt Block; aluminum tablet stamped " 813 ".

885.833

802.680

813. 302

Derwent, 0.8 mile south of, railroad crossing of Baltimore and Ohio and

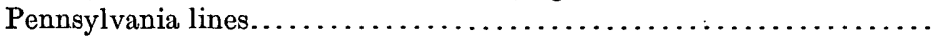

Pleasant City, at northeast corner of Pennsylvania Railroad station;

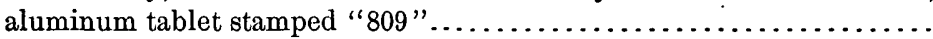

Pleasant City, in front of station; top of rail........................

Ava, 0.59 mile north of, in top of concrete culvert, west of track; aluminum tablet stamped " 809 " 
FREELAND, SOUTHEAST ALONG OHIO RIVER AND WESTERN RAILWAY, TO BELLE VALLEY.

Spratt, 0.3 mile east of station, in south face of southwest corner of Spratt's milk house 50 feet north of highway; aluminum tablet stamped " 941 $1908 "$.

Feet.

Cumberland, 0.5 mile west of, 90 feet south of railroad, on northwest corner of northwest wing wall of highway bridge; chisel mark........

Cumberland, in top foundation stone of flying buttress at center of south side of First Presbyterian Church; aluminum tablet stamped " $862-$ $1908 "$.

940. 448

837. 43

Hiramsburg, 70 feet north of station, in south face at southeast corner of G. A. McClure's dwelling, 1.9 feet above ground; aluminum tablet stamped " $967-1908$ ".

Belle Valley, 1,500 feet south of station, in bridge seat at southeast corner of Pennsylvania Railroad bridge over Duck Creek; aluminum tablet stamped "739-1908"

NEW CONCORD, SOUTH, VIA CLAYSVILLE, TO SPRATT.

New Concord, 60 feet north of station, in concrete street crossing about 3 inches above ground; iron post stamped " 843 ".

843.243

New Concord, 2.75 miles southeast of, 1,000 feet north of J. Keck's residence, in south side of west abutment of covered bridge over Crooked Creek; aluminum tablet stamped " 831 "

New Concord, 4.6 miles southeast of, 15 feet east of public road, at the residence of Harley Watson, on concrete walk; chiseled square painted " 1128.47 "

Claysville, 0.87 mile west of, 150 feet south of public road, in northwest corner of foundation of residence of E. E. and J. J. Kelley; aluminum tablet stamped " 1022 ".

Rix Mills, 0.5 mile south of, 150 feet east of T road, in southeast corner of foundation to residence of B. W. St. Clair; aluminum tablet stamped "1113".....

Spratt, 2.34 miles north of, 700 feet south of $H$. Tonis's residence, in concrete step at entrance of Rich Hill high school; aluminum tablet stamped "1088".

RENROCK, WEST TO ROWLAND.

Renrock post-office, 250 feet south of $T$ road, 15 feet east of public road, in northwest corner of foundation to Silas Thorlas's residence; aluminum tablet stamped " 793 ".

Renrock, 1.24 miles west of, 100 feet south of Dickerson's residence, 7 feet from center of road, on large rock on west side of road; chiseled square marked " 909,9 ".

Knight, 150 feet south of Grove Church, at southeast corner of crossroads, on rock at end of culvert; chiseled square painted " 1014.51 "....... 1,014. 53

Knight, 0.5 mile west of, 10 feet from center of road 0.05 mile east of $T$ road; spike in root of oak tree painted "1064.16"...

Knight, 1.22 miles west of Grove Church, 75 feet south of public road leading from Knight to Lisleburg, in northeast corner of foundation to residence of J. C. Wilson; aluminum tablet stamped " 1091 ".......... 1, 091.515

Young Hickory (Lisleburg), 580 feet west of church, 50 feet east of Marietta and Cumberland road, on stone in center of $T$ road; chiseled square painted " 1070.68 " ................................... 1,070. 71 
CALDWELL QUADRANGLE.

DUDLEY, NORThWEST ALONG PENNSYlVANIA RAILROAD, TO CALDWELL.

Dudley, 0.8 mile south of, at milepost 31 ; railroad bench mark.

Feet.

Dudley, dwelling house of Elmer Tilton, on north side at northwest corner, in face of foundation wall; bronze tablet stamped " 705 COLUMBUS"..

Dudley, 0.12 mile north of, at milepost 32 ; railroad bench mark.........

Dudley, 1.25 miles north of, at milepost 33 ; railroad bench mark.........

Matron, 1.25 miles north of, at milepost 34 ; railroad bench mark.........

Caldwell, at northwest corner of Noble County court-house, in north face of base stone 1 foot above ground; aluminum tablet stamped "746 COLUMBUS".

697.88

704. 390

706. 91

707.04

720.53

745. 377

CALDWELL, WEST TO RENROCK.

Caldwell, in top of basc rock on south side of Mills Block, 5 feet east of entrance of post-office; aluminum tablet stamped " 747 ".

Caldwell, 1.15 miles south by 1.45 miles west of, 60 feet west of $T$ road south, on large flat rock; chiseled square painted " $1007.41 " \ldots \ldots \ldots .1,007.41$

Sharon, in northeast corner at east side of foundation of residence of A.J.

Lowe; aluminum tablet stamped " 942 ".

Sharon, 2.95 miles west of, in northeast corner at east side of foundation of residence of James Caldwell; aluminum tablet stamped "1015"........ 1, 015. 178

Renrock, 1.53 miles east of, on rock ledge on north side of road; chiseled square marked " 1044.98 "

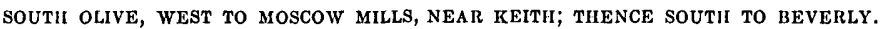

South Olive, 1.43 miles west of, south of road, on sandstone ledge; chiseled square painted " 955 "

955.09

South Olive, 2.65 miles west of, in north abutment west side of new concrete-iron bridge on $T$ road south; aluminum tablet.................

Keith, 1 mile east of, 500 feet north of bridge over Keith Fork Olive Green Creek, at junction of Lowell and Caldwell roads, in face of brownstone ledge on north side of $T$ road west; aluminum tablet stamped "Prim. Trav. Sta. No. $9799 "$.

799. 364

Keith, on stone in front of store owned by P. C. Keith \& Son; chiseled square painted " 746.67 "

746. 75

Keith, 2.09 miles west of, in west side of south abutment of covered bridge over Little Olive Green Creek on $T$ road; aluminum tablet stamped "713".

834.236

Keith, 5.11 miles west of, 50 feet north of public road, in southwest corner of foundation of D. P. Oliphant's residence; aluminum tablet stamped " 724 ".

Keith, 6.72 miles west of, south of public road, 100 feet west of $T$ road east, 4 feet west of barn owned by J. Beebe, on large flat rock; chiseled square marked " 732.6 ".

723.939

Keith, 8.38 miles west of, on large rock at south side of public road; chiseled square marked " 804.3 "

732.81

804.48

Beverly, 3.66 miles north of, 0.31 mile north of $Y$ road, 0.17 mile south of crossroads, in brownstone ledge on east side of road; aluminum tablet stamped " 842 ".

Beverly, 2.61 miles north of, at $T$ road south, on rock in front of residence of P. S. Taylor; chiseled square marked " 926.69 ".

926.96

Beverly, in top of west wall at north end of government canal lock at foot of Fifth street; aluminum tablet stamped "Prim. Trav. Sta. No. 7 631.". 
BEVERLY, EAST ALONG HIGHWAY, TO WHIPPLE.

Waterford crossroads, at northeast corner of C. E. Vaughn's store; chiseled square marked " 643.2 "

Equity, 1.47 miles north of Baltimore and Ohio Railroad station, 8 feet east of south rail of railroad, in brownstone ledge; aluminum tablet stamped " 654 ".

Clifton, in front of Baltimore and Ohio Railroad station, top of rail; marked " $637.7 "$

Clifton, 0.6 mile south of railroad station, on Riverview farm, in concrete culvert under railroad; aluminum tablet stamped " 627 " .............

Lowell, government lock; chiseled square........................

Lowell, in top of east wall at north end of canal lock 3; aluminum tablet stamped "Prim. Trav. Sta. No. 3617 Columbus"....................

Feet.

643.53

654.600

626.863

616.62

616.651

KEITH, SOUTH ALONG HIGHWAY, TO LOWELL.

Keith, 2.22 miles south of, on rock south of road; chiseled square painted "869.3"

Keith, 3.27 miles south of, 660 feet south of $T$ road east, on property stone in center of public road; chiseled square painted "1050.4"

Keith, 5.5 miles south of, 40 feet west of public road, in southeast corner of foundation of barn owned by John Steigle; aluminum tablet stamped " 926 "

Lowell, 4 miles north of, 30 feet east of ford over big run at crossroads, in large flat rock on west side of road; aluminum tablet stamped "641"...

Lowell, 2.5 miles north of (along river), at $T$ road, on west side of north abutment of covered bridge; chiseled square painted " 615.8 " ........

WATERFORD, WEST ALONG BALTIMORE AND OHIO RAILROAD, TO ROXBURY.

Waterford, 3 miles north of, 280 feet south of Hayward station, 200 feet east of railroad, in top step to entrance of E. B. Vincent's residence; aluminum tablet stamped " 645 ".

Beckett, in northwest corner of concrete retaining wall around station platform; aluminum tablet stamped " 647 ".

Luke Chute, in southeast corner of top of government lock; aluminum tab-

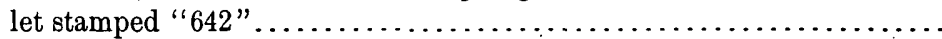

NEAR CLOUd POST-OFFICE.

Meigs, 3.29 miles northeast of, in west side of south end of foundation of $\mathbf{J}$. Q. Little's residence; aluminum tablet stamped " 749 ".............

Cloud post-office, east of road opposite MacKlem \& Dunkle's store; nail head in root of buckeye tree, paint mark " $770.749 "$ "................

769.92

\section{M'CONNELSVILLE QUADRANGLE.}

EAGLEPORT, SOUTH TO CALVARY.

Eagleport, 2.7 miles west of, on rock at $T$ road west; chiseled square,

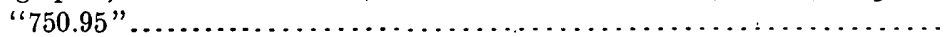

Eagleport, 3.79 miles southwest of, 150 yards southwest of residence of Jacob Bush, in east side of north abutment of wooden bridge; aluminum

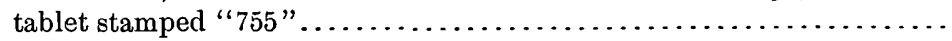

Triadelphia, in northwest corner at west side of foundation of Christian Church; aluminum tablet stamped " 982 "........................ 
Triadelphia, 2.95 miles south of, at crossroad, in southeast corner at east side of foundation of residence of James Parkhill; aluminum tablet stamped " 844 ".

Feet.

Morgansville, in east side of foundation of residence of Androw scott; aluminum tablet stamped " 883 ".

843. 772

883.475

Ringgold, 0.5 mile east of, on large rock at crossroads; chiseled square painted " 891.47 "

891. 69

Ringgold, 0.31 mile east of, in south side of west abutment of bridge over small stream; aluminum tablet stamped " 871 "

Ringgold, 2.78 miles south of, on rock at $T$ road east; chiseled square painted "1062.75".

Shilling, 0.91 mile south of, in northwest side of foundation of residence of M. H. Fitch; aluminum tablet stamped "1058".

Mountville, 40 feet north of $T$ road, on large rock, at schoolhouse; chiseled

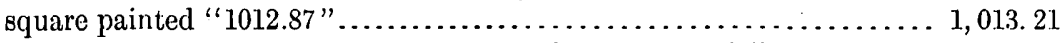

Mountville, in south wall of foundation of residence of John McLain; aluminum tablet stamped " 1026 "

Mountville, 0.84 mile south of, at $T$ road east, on stone step at gate leading to residence of $O$. Lovell; chiseled square painted " 977.39 " ...........

Mountville, 1.78 miles south of, 30 feet south of crossroads east and west, on large rock; chiseled square painted " 979.15 ".

DURANT, SOUTH, VIA M'CONNELSVILLE AND STOCKPORT, TO CHESTERHILL.a

Eagleport, 1.58 miles south of, in west abutment of small culvert under

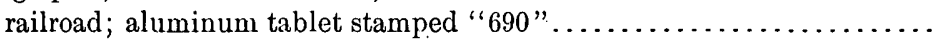

Shawnee Junction, 0.12 mile north of, in east side of south abutment of small trestle; aluminum tablet stamper " 686 "

Malta, northeast corner of intersection of Bell and Water streets, in concrete retaining wall; aluminum tablet stamped " $666 "$ "..................

McConnelsville, in southeast corner of veranda of Morgan County courthouse; iron post stamped "Prim. Trav. Sta. No. 12 701"...............

McConnelsville, on porch of Morgan County court-house; chiseled square

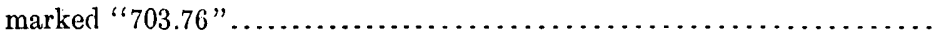

Malta, 3.01 miles south of, on west side of Baltimore and Ohio Railroad, 300 feet south of railroad crossing, in coping stone of small culvert; aluminum

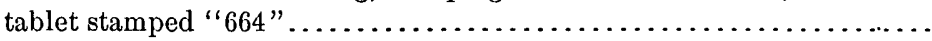

Hooksburg, 0.38 mile south of station, 60 feet east of railroad, in coping stone of stone-arch culvert under county road crossing; aluminum

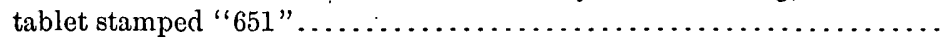

Stockport, 700 feet west of railroad, in north side of west abutment of county bridge over Muskingum River; aluminum tablet stamped " 663 ".......

Stockport, 1.1 miles west of, on coping stone of small culvert; chiseled

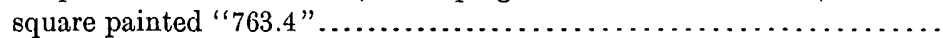

Stockport, 2.27 miles west of, in north side of west abutment of wooden bridge; aluminum tablet stamped " 873 ".

686.370

666.041

700. 940

703. 44

664.218

650.755

662. 601

763.24

872.589

Stockport, 3.41 miles west of, on south side of east abutment of iron bridge; chiseled square painted " 794 ".

Todds, 11 feet from center of road at intersection of $Y$ road, on large flat stone; chiseled square painted " 988 ".

Chesterhill, 1.28 miles northeast of, on coping stone of east abutment at north side of covered bridge over Wolf Creek, chiseled cross painted "724.8". 
STOCKPORT, SOUTHEAST TO ROXBURY.

Roxbury, 450 feet north of ferry over Muskingum River, at triangle at junction of North River road and road south across river; iron post stamped "Prim. Trav. Sta. No. 6 655.5".

Feet. side of railroad; aluminum tablet stamped " 654 "..................

M'CONNELSVILLE, NORTHEAST TO ROWLAND.

McConnelsville, 0.85 mile northeast of, on rock on east side of road; chiseled square marked " 744.25 ".

McConnelsville, 2.93 miles northeast of, in south abutment at west side of iron bridge over Fourmile.Creek; aluminum tablet stamped " 844 ".....

McConnelsville, 4.08 miles northeast of, 40 feet south of small walnut tree, on rock west of road; chisel cut marked " 996.24 ".

McConnelsville, 4.78 miles northeast of, on east side of south abutment of covered bridge over Meigs Creek; chisel cut marked "703.97".

McConnelsville, 6.26 miles northeast of, in east side of north coner of foundation of residence owned by Chas. $\mathrm{H}$. Whitney; aluminum tablet stamped " 767 "

Meigs, 0.91 mile east of, on south side of west abutment of iron bridge; chiseled square marked " 679.320 ".

678.51

Meigs, 1.1 miles east of, at $T$ road south, on large rock in front of residence of John King; chiseled square marked " 727.545 ".................

Meigs, 1.92 miles north of, on large rock at crossroads; chiseled square marked " 692.624 ".

PHILO' QUADRANGLE.

SOUTH ZANESVILLE, SOUTHEAST ALONG BALTIMORE AND OHIO RAILROAD, TO DURANT.

Buckeye, in front of station; top of rail (marked "713.2.")..............

Buckeye, 0.25 mile south of station, in wing at east side of county bridge, 50 feet east of Baltimore and Ohio Railroad; aluminum tablet stamped " 688 "

Frazier (formerly Brush Creek) station, in northeast corner of A. M. Shy- lock's field, 24 feet from Baltimore and Ohio Railroad; 31 feet from center of north-south road; iron post stamped "Prim. Trav. Sta. No. 63 701"..

Government lock at Philo, chiseled square marked " 688.5 " ...........

Philo, 0.22 mile north of station, 20 feet east of Baltimore and Ohio Railroad, in retaining wall of county bridge over Muskingum River; alumi-

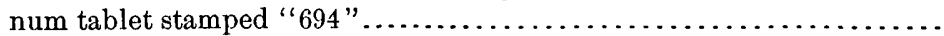

Philo, in front of station; top of rail (marked " $701 ") . . . \ldots \ldots \ldots . . . . .$.

Philo, 1.78 miles south of; 30 feet from Baltimore and Ohio Railroad, in stone-arch bridge on west side; aluminum tablet stamped " 685 ".......

Merriam, 0.82 mile south of, in west-side coping of cement culvert; aluminum tablet stamped " 690 ".

713. 3

700.958

687.897

693.933

701. 0

684. 943

690.033

Durant, 300 feet west of railroad, 25 feet from public road; iron post stamped "Prim. Trav. Sta. No. 67 676.4"

ZANESVILLE, SOUTHEAST, VIA OHO RIVER AND WESTERN RAILWAY, TO FREEIAND.

Zanesville, on northwest corner of curb approach to Fifth Street Bridge; chisel mark...........................................

Mill Run station, 1 mile east of Zanesville, on northwest corner of stone bridge over Mill Run; chisel mark 
Deffenbaugh, 1,200 feet east of, 200 feet north of railroad, in southwest corner wing wall of small dirt-road bridge, 2 feet below bridge floor; aluminum tablet stamped " 805 ".

Feet.

Carlwick, 700 feet west of station, at road fork, in bridge seat at southeast corner of bridge over Boggs Creek; aluminum tablet stamped " 740 "....

Chandlersville, at southeast corner of $T$ road to south, in west face of stone stile block by I. O. O. F. building; aluminum tablet stamped " $734-1908$ ".

Freeland, 152.2 feet southwest of station, in George Thorla's field, on top of 12 by 12 inch rock post; chisel mark ("Prim. Trav. Sta. No. 69766 ")..

804.835

739.598

733.464

765.986

ROWLAND, NORTII TO FREELAND.

Riowland, 0.5 mile north of former post-office, at $T$ road west, in northeast corner of Walton Blackledge's field; iron post stamped "Prim. Trav. Sta. No. 68738 ".

Rowland, 2.17 miles north of, on large rock east of road at $T$ road east; chiseled square marked " 756.64 ".

755.80

Rowland, 3.81. miles north of, 80 yards east of private road learling to Oakland Church, on west side of south abutment of bridge over creek; aluminum tablet stamped " 757 "

Rowland, 5.77 miles north of, on rock at $T$ road west; chiseled square painted "1047.21".

Rowland, 6.72 miles north of, on large rock east of road; chiseled square painted " $1157.76 " \ldots \ldots \ldots \ldots \ldots \ldots \ldots \ldots \ldots \ldots \ldots \ldots \ldots \ldots \ldots \ldots \ldots \ldots \ldots \ldots ., 156.92$

Rowland, 7.26 miles north of, in third stone step at south door at east side of Highhill Presbyterian Church; aluminum tablet stamped "1198"... 1, 197. 276

Highhill, in front of N. J. Bell's store, on large rock; chiseled square marked " 11.89 .8 " ..................................... 1, 188.97

ZANESVILLE, NORTU 5 MILES.

Zanesville, 3 miles north of, just west of Zanesville-Gilbert road, between the Baltimore and Ohio and the Cincinnati and Muskingum Valley railroads, in southeast corner of field of Mrs. Marguerite Clark, in stone post; aluminum tablet stamped "Prim. Trav. Sta. No. 62705 "............

Zanesville, 3.6 miles north of, in ground on west side of track opposite milepost "T-13;" top of rail set vertically (marked "B. M. 723 ") ..........

Zanesville, 4.6 miles north of, in ground on west side of track opposite milepost "T-12;" top of rail set vertically (marked "B. M. 721 ").........

CONESVILLE QUADRANGLE.

POINT 5.(i MILES NORTI OF ZANESVILLE, NORTH 5 MILES.

Zanesville, 5.6 miles north of, in ground west of track opposite milepost "T-11;" top of rail set vertically (marked "B. M. 724") . . . .............

Gilbert, 300 feet south of station, in top of north abutment of railroad

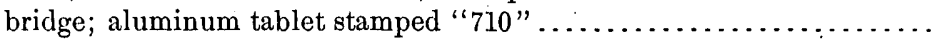

Gilbert, in front of station; top of rail . ..........................

Gilbert, 1.6 miles north of, west of track opposite milepost "T-9;" top of rail set vertically inground (marked "B. M. 736").................

Ellis, 0.5 mile north of, west of track opposite milepost "T-8;" top of rail set vertically in ground (marked "B. M. 723 ")....................

Ellis, 1.5 miles north of, west of track opposite milepost "T-7;" top of rail

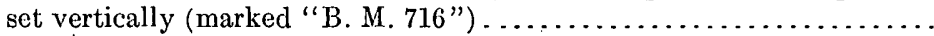

Ellis, 1.6 miles north of, 100 feet south of flag station, 80 feet west of track, west of road, in top of culvert masonry; aluminum tablet stamped "716".

Ellis, 2.5 miles north of, west of track opposite milepost "T-6;" top of rail

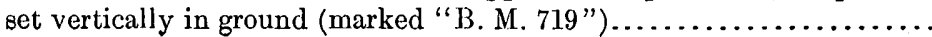


TRINWAY, NORTHEAST, VLA CONESVILLE, TO COSHOCTON.

Adams Mills, in canal lock, in top of south end at east side of gate wall; aluminum tablet stamped " 736 "...........................

Adams Mills, 2.5 miles east of, 60 feet west of milepost "P-130," in culvert 10 feet south of Pennsylvania Railroad; aluminum tablet stamped " 748 ". Conesville, in front of station; top of rail.

Feet.

735.765

747.970

745. 6

Conesville, 1,170 feet north of station, west of track, in front foundation stone of water tank; aluminum tablet stamped " 745 " ................

Franklin, in front of station; top of rail . . . . . . . . . . . . . . . . . . . . .

Franklin, 1.6 miles north of, at railroad crossing, in top of bridge seat on west side of north end of abutment of highway bridge; aluminum tablet stamped " 769 ".

744.981

755.0

769. 193

SONORA, NORTH TO CONESVILLE.

Sonora, 40 feet northeast of Baltimore and Ohio Railroad station; iron

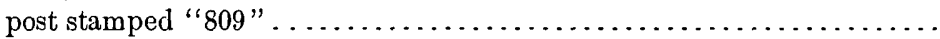

Sonora, 1.34 miles west of, on concrete bridge; chiseled square marked

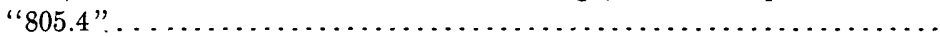

Sonora, 1.52 miles west of, in field at northeast corner of T road; top of iron post painted " 848.2 ".

'Sonora, 2.52 miles northwest of, 600 feet north of C. Reichel's residence, in northeast abutment of stone-arch bridge; aluminum tablet stamped " $877 "$

808. 637

805. 35

848. 16

876.800

East Greenwood, center of $T$ road east, in top of section corner stone; aluminum tablet stamped " 982 ".

981.837

Adamsville, 1.54 miles south of, in east abutment of concrete bridge over Simms Creek; aluminum tablet stamped " 849 ".

849.091

Opposite T road west, on northwest corner of barn; chiseled square marked

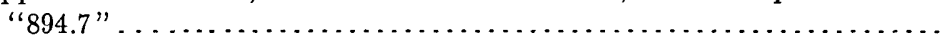

Adamsville, 0.91 mile south of, at northeast corner of T road east, on stone; chiseled square painted " 1005.6 "

894.57

Adamsville, in northeast corner of street crossing in front of hotel, on large stone; chiseled square marked "1019.8" . . .................... 1,019. 19

Adamsville, 1.57 miles north of, on rock in center of $T$ road west; chiseled square marked " 982.2 ".

Adamsville, 2.31 miles north of, 500 feet north of T road east, 60 feet west of public road, in southeast corner of barn owned by F. Hanks; aluminum tablet stamped " 1032 ".

Adamsville, 3.61 miles north of, at $Y$ road east, in center of road, 4 feet from west fence; chiseled square painted " $1006.0 " \ldots \ldots \ldots \ldots \ldots \ldots .1,005.90$

Ferncliff, 0.25 mile south of, in southeast corner of foundation of $J$. W. Vensel's house; aluminum tablet stamped " 1081 "

Wills Creek, 3.07 miles south of, on west side of south abutment of bridge over Wolf Creek; chiseled square marked " 742.1 "

741.91

Wills Creek, 2.36 miles south of, 150 feet north of T road, in west side of south abutment of small wooden bridge; aluminum tablet stamped " 751 "....

Wills Creek, 2 miles south of, on east side of north abutment of iron bridge; chiseled square marked " 744.9 ".

Wills Creek, 0.9 mile south of, 50 feet west of large covered bridge, at T 'road east, on large rock; chiseled square marked " 738.6 "............

Wills Creek, 50 feet west of $T$ road, in west side of north abutment of new iron bridge; aluminum tablet stamped " 747 " ..................

Wills Creek, 0.88 mile west of, 350 feet west of Robison Church, on large stone north of road; paint spot (painted " $858.9 "$ ") ................ 
Conesville, 0.5 mile north of, tool house and waiting room of Wheeling and Lake Erie Railroad station, on southwest corner of platform; bolt head painted " 744.4 ".

Feet:

Conesville, 1,170 feet north of station, west side of front foundation of Pennsylvania Railroad water tank; aluminum tablet stamped " 745 ".......

744. 11

744.981

point 3 miles southwest of plainfigld, via marquand, to point 2 miles south of wills cReek.

Plainfield, 3.92 miles southwest of, 50 feet east of $T$ road north, in north side of west abutment of small wooden bridge; aluminum tablet stamped " 74.9 "

749.466

Marquand, 0.55 mile north of, at T road north, on top step of church; chiseled square marked "791.9".

791.87

Marquand, in west side of south pier of iron bridge over Wills Creek; alu-

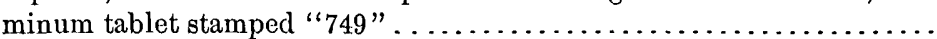

Marquand, 1.09 miles west of, on large rock north of road; chiseled square

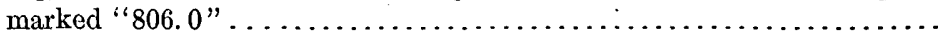

MARQUAND, SOUTHEAST, VIA OTSEgo, TO BLOOMFELD.

Marquand, 2.09 miles east of, on south side of east abutment of small wooden bridge; chiseled square marked " 805.6 ".

Otsego, at southeast corner of schoolhouse; iron post sta mped "Prim. Trav. Sta. No. $59809 "$ ".

Otsego, 1.05 miles south of, on stone on east abutment of small culvert; chiseled square painted " 793.6 "

Otsego, 3.35 miles south of, in west side of south abutment of small wooden bridge; aluminum tablet stamped " 815 " .....................

\section{CAMBRIDGE QUADRANGLE.}

POINT 2 MiLES SOUTIIEAST OF WRST LAFAYETTE, SOUTI TO POINT 2 MILES SOUTHWEST OF PLAINFIELD.

West Lafayette, 2.44 miles southeast of, at $Y$ road, 150 feet southeast of brick schoolhouse, on large flat stone; chiseled square painted " 813.3 "..

West Lafayette, 3.43 miles south of, in east side of north abutment of iron bridge; aluminum tablet stamped " 815 ".

Plainfield, 0.87 mile north of, on west side of south abutment of iron bridge; chiseled square painted " 765.3 "

Plainfield, 0.5 mile southwest of, at southeast corner of $T$ road, on large rock; chiseled square painted "801.1".

Plainfield, 1.93 miles southwest of, in east side of north abutment of iron bridge; aluminum tablet stamped " 751 "

751.332

BIRDS RUN, WEST TO OTSEGO.

Birds Run, 2.52 miles west of, on large rock 100 feet west of T road south; chiseled square painted " 798.13 " ...........................

Linton Mills, in north end of east abutment of iron bridge over Wills Creek; aluminum tablet stamped " 764 ".

Linton Mills, 3.78 miles west of, in east side of south abutment of wooden bridge over Coal Run; aluminum tablet stamped " 759 ".

758.475

Linton Mills, 5.08 miles west of, at T road south, on stone step at Buker schoolhouse; chiseled square painted " $803.31 " \ldots \ldots \ldots \ldots \ldots \ldots . . . . . .$.

803.01

BLOOMFIELD, SOUTH TO NEW CONCORD.

Bloomfield, 0.98 mile north of, on east side of south abutment of small iron bridge at foot of large hill; chiseled square marked " 845.8 " . . . . . . . .

Bloomfield, at $T$ road east, in southwest corner of foundation of Geyer \& 845.68 Sandles's store; aluminum tablet stamped " 1117 ".............. 1, 116.801 
Bloomfield, 0.79 mile south of, on east side of north abutment of small wooden bridge at foot of hill; chiseled square marked " 952.4 " ........

Bloomfield, 2.2 miles south of, 1,000 feet east of schoolhouse, in north side of east abutment of small bridge; aluminum tablet stamped " 885 "...... New Concord, 60 feet north of station; iron post stamped " 843 " $\therefore . . . . .$.

Feet.

$95 \dot{2} .29$

884. 733

843. 243

CAMBRIDGe, via CRATG, clio, aNd EAST SALEM, to kimbolton.

Cambridge, in top step at front entrance of court-house, about 1 foot from building; aluminum tablet stamped " 886 "

Cambridge, 2.32 miles east of, 100 feet west of $T$ road south, on stone culvert north of road; chiseled square marked " 801.6 ".

885.833

801.43

Cambridge, 3.04 miles east of, in milepost at northeast corner of crossioadis, marked "Cumberland 177, Wheeling 47;" aluminum tablet stamped " $799 "$

Craig, 0.3 mile west of, on large flat rock in middle of National Pike at $T$

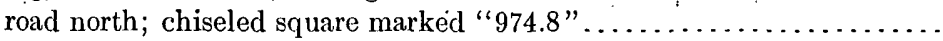

Craig, 2.2 miles north by about 0.3 mile west of, in stone step of Independence schoolhouse; aluminum tablet stamped " 1145 ".

Midway triangulation station, about 6 miles northeast of Cambridge and 1.5 miles southeast of village of Midway, 200 feet west of north-south road, 300 feet northwest of schoolhouse, on a prominent bald hill; bronze tablet stamped " 1172 "

Clio, 3 feet from store, at southwest corner of crossroads, on stone; chiseled

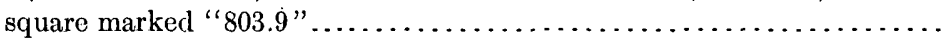

Kimbolton, 3.17 miles east of, north of road at $Y$ road south, 500 feet west of residence of Howard Millegan, in brownstone ledge; aluminum tablet stamped " 866 ".

East Salem, 500 feet east of, 18 inches from fence, on rock south of public road; chiseled square marked " 1056.56 ". .

Kimbolton, 60 feet north of station, in property stone at corner of barn; aluminum tablet stamped " 787 ".

NEAR BERNICE.

Bernice, 1.5 miles southeast of, in west side of south abutment of iron bridge over Dunlap Creek; aluminum tablet stamped " 824 " . . . . . . .

CAMBRIDGE, EAST 5 MILES.

Cambridge, 1.04 miles east of, in coping stone on south side of east abutment of bridge over Leatherwood Creek; chiseled square painted "804.4".... Guernsey, in front of station; top of rail (marked " 804.7 ") .............. Guernsey station, 0.89 mile east of, on north side of east abutment of bridge over Leatherwood Creek; chiseled square painted "803.8" . . . . . . . . .

804.31

804.6

803.69

COSCHOCTON QUADRANGLE.

COSHOCTON, EAST TO WEST LAFAYETTE.

Coschocton, in front of station; top of rail........................

Coschocton, at southeast corner of court-house; aluminum tablet stamped "Prim. Trav. Sta. No. 57-777"

777. 0

776. 868

Coshocton, 3.2 miles east of, 900 feet west of milepost "P-119," :in front face of concrete foundation of semaphore pole; aluminum tablet stamped "767"

767.632

Coshocton, 4 miles east of, at crossing of the Wheeling and Lake Erie Railroad and the Pennsylvania line; top of rail,.,.,.,., , , , , , , , , . 
NEW COMERSTOWN QUADRANGLE.

WEST LAFAYETTE, EAST, VIA NEW COMERSTOWN, TO BERNICE.

Feet.

802. 0

West Lafayette, in front of station; top of rail....................

West Lafayette, in northwest corner of public school grounds, 120 feet south of Pennsylvania Railroad; iron post stamped "Prim. Trav. Sta. No. 58-809".

809. 351

Isleta, 265 feet east of station, 25 feet north of track, in railroad culvert; aluminum tablet stamped " 791 "............................

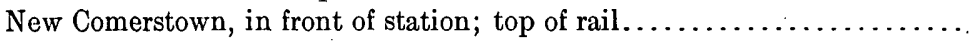

New Comerstown, in front step, at northwest corner of Fountain Hotel, 1 foot from sidewalk; aluminum tablet stamped " 805 " .............

New Comerstown, in foundation of high school building, 6 feet south of College street entrance; aluminum tablet stamped " $809 " . . . \ldots \ldots \ldots$.

Bernice, 1.95 miles west of, in east side of north abutment of iron bridge over Dunlap Creek; aluminum tablet stamped " 802 "...............

Bernice, 1,013 feet east of, at $Y$ road, on large rock on north side of small concrete culvert; chiseled square painted " $822.55 " \ldots \ldots \ldots \ldots \ldots \ldots$.

805. 191

808. 623

803. 178

823.48

OIROLEVILLE, FRAZEYSBURG, FREDERICKTOWN, GRANVILLE, LANCASTER, LOGAN, NEWARK, NEW LEXINGTON, THORNVILLE, THURSTON, AND ZANESVILLE QUADRANGLES.

ATHENS, COSHOCTON, FAIRFIELD, HOCKING, KNOX, LICKING, MUSKINGUM, AND PERRY COUNTIES.

The leveling was done in 1907 in Frazeysburg, Newark, Granville, Zanesville, Thornville, New Lexington, and Logan quadrangles by W. H. Monahan; in Frazeysburg, Zanesville, and New Lexington quadrangles by E. C. Bibbee; in Newark, Thornville, Thurston, Logan, Lancaster, and Circleville quadrangles by C. H. Burns; in Newark, Granville, and Fredericktown quadrangles by R. C. Seitz; in Newark, Granville, and Thurston quadrangles by I. M. Flocker. Additional work was done in 1908 in Zanesville and New Lexington quadrangles by T. A. Green, and in Frazeysburg quadrangle by C. H. Semper.

\section{FRAZEYSBURG QUADRANGLE.}

TRINWAY, SOUTH 5 MILES.

Trinway, crossing of the Pennsylvania line and the Cincinnati and Muskingum Valley Railroad; top of rail.

Feet.

Trinway, at southwest corner of Pennsylvania Railroad station, in top of stone curb around cellar window; aluminum tablet stamped " 731 ."...

Dresden, 1 mile north of, east of track in front of milepost "T-1;" top of rail set vertically in ground (marked "B. M. -735 ") ................

Dresden, 30 feet east of Cincinnati and Muskingum Valley Railroad, near northwest corner of public school grounds; iron post stamped "Prim. Trav. Sta. No. 54-740".

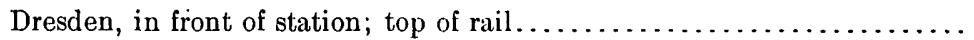

Ellis, 5.5 miles north of, west of track, opposite milepost "T-3;" top of rail set vertically in ground (marked "B. M. $-745 ")$. . . . . . . . . . . . .

Ellis, 4.5 miles north of, west of track, opposite milepost "T-4;" top of rail set vertically in ground (marked "B. M. -752 ") . . . . . . . . . . . . . .

'Ellis, 3.5 miles north of, west of track, opposite milepost "T-5;" top of rail set vertically in ground (marked "B. M. -724 ") ................... 9639-Bull. $411-09-6$

730. 1

731. 160

735.40

739. 3

745. 21

752.42

723.75 
HANOVER, EAST ALONG PENNSYlVANIA RAILROAD, TO TRINWAY.

Hanover, 2.4 miles east of, in stone abutment used as a culvert on north side of rock drive under railroad; aluminum tablet stamped " 813 ".....

Black Run, 530 feet south of, in west side of north abutment of iron bridge over Black Run; aluminum tablet stamped " 766 "................

Frazeysburg, 0.5 mile north of Pennsylvania Railroad station, in second step of east door step of city building; aluminum tablet stamped " 757 "..

Frazeysburg, 3 miles east of, 60 feet south of south track, in base rock of highway bridge over Pennsylvania Railroad; aluminum tablet stamped "768"

TRINWAY, NORTH ALONG CLEVELAND, AKRON AND COLUMBUS RAILWAY, TO COOPERDALE; THENCE WEST AND SOUTH ALONG HIGHWAYS, TO BLACK RUN.

Trinway, 0.5 mile north of, 50 feet north of wagon road, in east side of north abutment of Cleveland, Akron and Columbus Railway bridge over canal; aluminum tablet stamped " 737 "..........................

Wakatomika, 0.13 mile northwest of station, in north side of east abutment of covered bridge; aluminum tablet stamped " 756 "...............

Cooperdale, 0.2 mile north of, in west side of south abutment of railroad

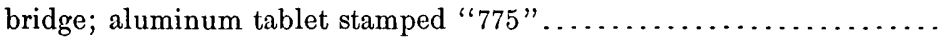

West Carlisle, 123 feet north of northwest corner of Presbyterian Church, in southwest corner of lot of H. M. Robinson; iron post stamped "Prim. Trav. Sta. No. 55" ................................... 1, 057.260

West Carlisle, 800 feet west of; in west side of foundation of Methodist Episcopal Church, 5 feet from southwest corner; aluminum tablet stamped "1040"

775. 361

West Carlisle, 3.4 miles west of, in west side of south abutment of iron bridge over Wakatomika Creek; aluminum tablet stamped " 822 "......

Perryton, 3 miles north of, 30 feet from wagon road, on north end of east side in foundation of Wright schoolhouse; aluminum tablet stamped " 801 ".

Perryton, in north side, northeast corner of foundation of schoolhouse;

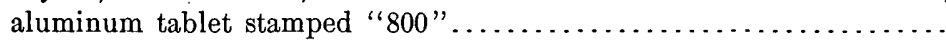

DILLON, NORTHWEST ALONG BALTIMORE AND OHIO RAILROAD, TO TOBOSO.

Dillon, 3.6 miles west of, in northeast abutment of railroad bridge over

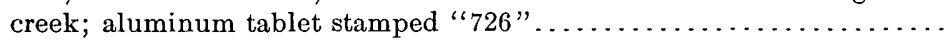

Nashport, in front of station; top of rail at road crossing................

Nashport, 0.01 mile west of, south of track, in south abutment of concrete culvert; aluminum tablet stamped " 758 ".

758. 2

757. 453

Toboso, in southeast corner of station platform; aluminum tablet stamped " $780 "$

Toboso, in front of station; top of rail

NASHPORT, SOUTHWEST TO COTTAGEHILL.

Cottagehill, 0.2 mile south of, in south abutment east side of small bridge;

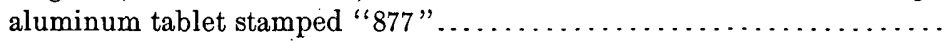

NEWARK QUADRANGLE.

UNTON STATION, EAST ALONG BALTIMORE AND OHIO RAILROAD AND PENNSY LVANIA RAILROAD, TO HANOVER.

Newark, on east side of court-house in stone step; aluminum tåblet stamped " 836 "

Newark, 2.4 miles east of, on south side of road, at forks to north and south, south of blacksmith shop, in sandstone abutment of iron bridge; alu-

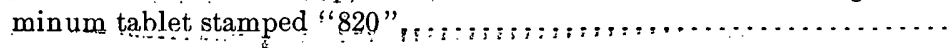


Claylick, on south side of road and south side of trolley, in sandstone abutment of county bridge over canal; aluminum tablet stamped " $790 " . .$.

Hanover, in sandstone abutment at southwest corner of bridge; aluminum

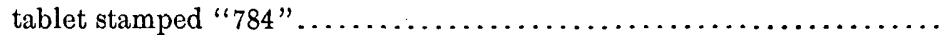

Hanover, in front of Pennsylvania Railroad station; top of south rail.....

NEWARK, SOUTH ALONG BALTIMORE AND OHIO RAILROAD 3 MILES.

Newark, 2.8 miles south of, in sandstone abutment on southeast corner of railroad bridge; aluminum tablet stamped " $844 " \ldots \ldots \ldots \ldots \ldots \ldots$.

844. 232

NEWARK, NORTH ALONG BALTIMORE AND OHIO RAILROAD, TO UTICA.

Newark, 3.3 miles north of, 100 feet from road, in sandstone foundation to large brick house on east side of road; aluminum tablet stamped " 887 "..

St. Louisville, 4.8 miles south of, on east side of road, east side of railroad, 60 feet from road, in sandstone post; aluminum tablet stamped " 882 "..

St. Louisville, 0.4 mile north of, in sandstone abutment of old covered bridge; aluminum tablet stamped " $907 "$ "......................

Utica, in sandstone doorstep at south end of city hall building; aluminum

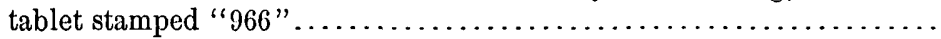

HANOVER, NORTH ALONG HIGHAY, TO LONG RUN; THENCE WEST AND NORTHWEST TO UTICA.

Hanover, 2.6 miles north of, on west side of road, in sandstone culvert; aluminum tablet stamped " 813 ".

Hanover, 6.5 miles north of, at road fork on west, in sandstone abutment of county bridge over Clear Fork; aluminum tablet stamped " 854 "......

Hanover, 10 miles north of, in southeast corner of sandstone abutment of old covered bridge; aluminum tablet stamped " $879 " . \ldots \ldots \ldots \ldots . .$.

Purity, in concrete doorstep of town hall; aluminum tablet stamped

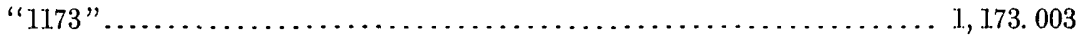

Purity, 3.4 miles north of, at northeast corner of crossroads, in sandștone doorstep of private house; aluminum tablet stamped "11.107"....... 1, 106. 506

Purity, 6.01 miles northwest of, at north side of road, in sandstone foundation of schoolhouse; aluminum tablet stamped " $1098 " \ldots \ldots \ldots \ldots \ldots .1,098.010$

Claylick, southeast along baltimore and ohio RaILRond, to toboso.

Claylick, in front of station; top of rail.

Toboso, 2.7 miles west of, north of track, in northeast abutment of iron bridge over creek; aluminum tablet stamped " 776 "...............

776. 040

CLAYLICK, SOUTH ALONG HIGHWY 3.7 MLES.

Claylick, 4 miles south of, in south part of grounds of Boodle School, 57 feet south of southwest corner of schoolhouse; iron post stamped "Prim.

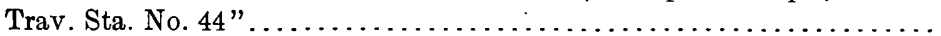

GRANVILLE QUADRANGLE.

CENTRAL CITY, NoRTHWEST ALONG OHIO CENTRAL RAILWAY, to CROTON.

Granville, 0.4 mile east of, 60 feet east of milepost " $\mathrm{T}-18-\mathrm{T}-1.30$," on end of vertical rail in center of track; cross..........................

Granville, in retaining wall at window at northeast corner of Doane Academy; aluminum tablet stamped " $1083 " . . \ldots \ldots \ldots \ldots \ldots \ldots \ldots \ldots \ldots . . . ., 082.332$

Granville, in window sill on north side of second floor of Science Hall; aluminum tablet stamped " 1102 ".

Granville, in front of station; top of rail

Clemons, in front of station; top of raill $;, \ldots \ldots \ldots \ldots \ldots \ldots \ldots,:,:$ : : : 
Clemons, 80 feet east of, 2.82 miles northwest of Granville, in base stone at southwest corner of water tank; aluminum tablet stamped " 925 ".......

Alexandria, in front of station; top of rail.......................

Alexandria, 0.4 mile northwest of, about 200 feet south of railroad, at west end of south abutment of small iron bridge at highway crossing; aluminum tablet stamped " 959 ".

Johnstown, city hall, in water table, 4 feet west of main entrance; aluminum tablet stamped " 1160 ".

Croton, 2.01 miles south of, 1,360 feet west of Ohio Central Railroad, at southwest corner of crossroads, in concrete fence post; aluminum tablet stamped " 1185 ".

Croton, 500 feet northeast of public square, in coping stone on west end of arch of masonry culvert; aluminum tablet stamped " 1139 " ......... 1, 139. 197

GRANVILLE, NORTH ALONG HighWY, TO HOMER.

Granville, 2.8 miles northwest of, in top of northwest wing wall of concrete culvert across highway; aluminum tablet stamped " 1061 "............ 1.,060.374

Granville, 6.7 miles northwest of, in southwest abutment of iron bridge across highway; aluminum tablet stamped " $1110 " \ldots \ldots \ldots \ldots \ldots \ldots \ldots .1,110.207$

Granville, 8.7 miles northwest of, 250 feet south of a house on left of highway, in top of west wing wall of concrete culvert; aluminum tablet

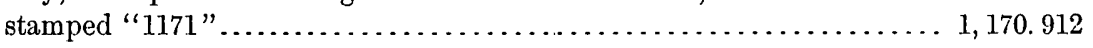

Granville, 11.8 miles northwest of, near forks of road, in top of northwest abutment of iron bridge over creek; aluminum tablet stamped "1012".. 1, 011.407

NEWWAY, EAST TO FREDONLA.

Fredonia, in west part of schoolhouse yard, 122.6 feet northwest of northwest corner of schoolhouse; iron post stamped "Prim. Trav. Sta. No. 37". 1, 247. 000

AT UNION STATION.

Union station, 0.75 mile south of, at crossroads, in southeast corner of Ira Shoneman's field; iron post stamped "Prim. Trav. Sta. No. 36 ".......

949. 167

pataskala, NORTh a long highWay, to johnstown.

Pataskala, 2.8 miles north of, in top of southeast abutment of iron bridge

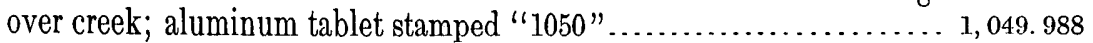

Jersey, 0.7 mile northwest of, in southwest corner of abutment of highway bridge at forks of road; aluminum tablet stamped "1101".......... 1, 100. 356

Jersey, 4.1 miles northwest of, in northwest corner of stone culvert across highway; aluminum tablet stamped " 1188 ".................... 1, 187.907

\section{FREDERICKTOWN QUADRANGLE.}

CROTON, EAST, YIA LOCK, TO HOMER.

Lock, 1.62 miles west of, at county line, in north end of bridge seat at west abutment of covered bridge over creek; aluminum tablet stamped "1118". 1, 117. 333

Lock, 2.04 miles east of, 200 feet west of crossroads, in coping at south end of culvert; aluminum tablet stamped " 1067 "................... 1, 066.944

Homer, in northwest part of public school grounds, 78 feet north of northwest corner of schoolhouse; iron post stamped "Prim. Trav. Sta. No. 38". 1, 008. 893

ZANESVILLE QUADRANGLE.

ZANESVILLE, NORTHWEST ALONG BALTIMORE AND OHIO RAILROAD, TO DILLON.

Dillon, in front of station; top of rail at road crossing..................

Dillon, 443 feet northeast of station, in southeast corner stone foundation of iron bridge over Licking Creek; aluminum tablet stamped " 713 "...... 
MOUNT PERRY, NORTH ALONG HIGHWAY, TO COTTAGEHILL.

Coaldale, 3 miles south of, at south side of M. E. Church, in fifth row of brick, 12 feet from east end; aluminum tablet stamped " 939 ".........

Coaldale, 1.2 miles north of, in east side of north abutment of small bridge;

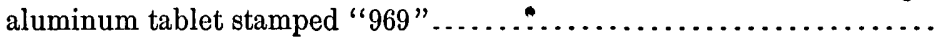

Feet.

938. 324

969.091

AT ZANESVILLE.

Zanesville, in front of Cincinnati and Muskingum Valley Railroad station;

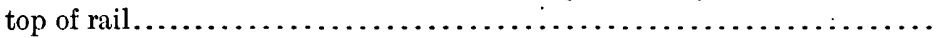

Zanesville, 0.6 mile north of, 6 feet north of milepost "T-16," 7 feet west of railroad; top of rail set vertically in ground.......................

701. 17

SOUTH ZANESVILLE, SOUTH TO CROOKSVILLE.

South Zanesville, 0.36 mile southwest of, in stone on east side of railroad;

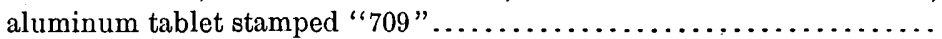

South Zanesville, in front of station; top of high rail.

709.576

728.8

South Zanesville, 2.3 miles southwest of, east of Cincinnati and Muskingum

Valley Railroad; point on sandstone rock marked " 711 "

711.02

South Zanesville, 3.3 miles southwest of, 495 feet south of private road crossing, in southeast corner of west stone abutment of iron railroad bridge over Johnson Creek; aluminum tablet stamped " $726-1908$ "......

South Zanesville, 6.46 miles southwest of, at Ironspot, 125 feet south of Cincinnati and Muskingum Valley Railroad, 300 feet north of Ransbottom Brothers' pottery factory, in west end of concrete abutment of bridge for railroad siding leading to factory; aluminum tablet stamped "732-1908".

Roseville, in front of station; top of rail (marked " 743 ") ................

Roseville, 2.1. miles southwest' of, 390 feet south of milepost "T-29", 30 feet west of railroad, in north end of sandstone culvert over running stream; aluminum tablet stamped "743-1908"

Crooksville, 60 feet south of Cincinnati and Muskingum Valley Railroad station, 3 feet west of tracks, 4 feet east of foot bridge, on west end of north abutment of iron railroad bridge over creek; chiseled square marked " 752 ".

725.840

731.913

742.6

742.873

752.28

MOUNT PERRY, SOUTH TO REHOBOTH.

Mount Perry, in west side of south abutment of covered bridge; aluminum tablet stamped " 802 ".

801. 499

Sego, in west side of north abutment of bridge at crossroads; aluminum tablet stamped " 832 ".

831.809

Sego, 0.86 mile south of, on east side of north wing of abutment of iron bridge; chisel cut (marked " 843 ").

843.12

Sego, 2.8 miles south of, on stone in southeast corner of barn yard of Wm.

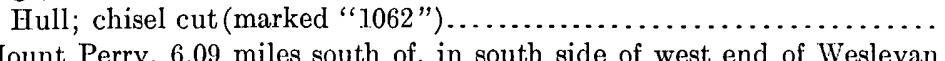

Mount Perry, 6.09 miles south of, in south side of west end of Wesleyan Chapel Church; aluminum tablet stamped " 1031 "................. 1., 030. 725

Wesleyan Chapel Church, 1.8 miles south of, south of road, on stone; chiseled square marked " 1068 " ................................. 1,067.57

Rehoboth, 2.24 miles west of, in foundation at east side of schoolhouse; aluminum tablet stamped " $1017 " \ldots \ldots \ldots \ldots \ldots \ldots \ldots \ldots \ldots \ldots \ldots . . \ldots \ldots ., 01.6 .488$

Rehoboth, 2.09 miles west of, on stone at top of hill; chisel mark (marked

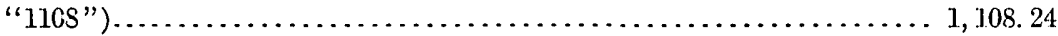


THORNVILLE QUADRANGLE.

GLENFORD, NORTH ALONG HIGHWAY, TO POINT 3.7 MILES SOUTH OF CLAYLICK.

Brownsville, 3.37 miles south of, in sandstone abutment at northeast corner of bridge; aluminum tablet stamped " 863 ".

Brownsville, in sandstone foundation of hotel; aluminum tablet stamped " $951 "$

THORNVILLE, NORTH ALONG BALTIMORE AND OHIO RAILROAD, TO POINT 2.8 MILES SOUTH OF NEWARK.

Thornville, in front of station at road crossing; top of rail.

897.1

Thornville, 3.4 miles north of, 150 feet west of railroad, in northeast corner of schoolhouse; aluminum tablet stamped " 972 ".

971.412

Thornville, 7.2 miles north of, 150 feet from track, in stone doorstep at north end of schoolhouse on east side of railroad; aluminum tablet stamped " $895 "$

NEW SALEM, SOUtheAST ALONG HIGHWAY, TO RUSHVILLE; THENCE EAST TO SOMERSET.

New Salem, 3.68 miles southeast of, 200 feet east of road fork to south, 30 feet north of road, in sandstone foundation of barn; aluminum tablet stamped " 1076 ".

New Salem, 5.86 miles southeast of, 1,064 feet north of road fork on west, in sandstone coping of arch on east side of road; aluminum tablet stamped "938"

937.636

Rushville, on southwest corner of street crossing, in northeast corner of Linnville Hotel; aluminum tablet stamped " 1053 ".

- Rushville, 2.5 miles east of, 2 miles north of Avlon, at crossroads, 45.6 feet southwest of southwest corner of Thomas Griffin's residence, in southeast corner of John Love's farm; iron post stamped "Prim. Trav. Sta. No. 51".

Rushville, 5.3 miles northeast of, in northeast abutment of stone culvert; aluminum tablet stamped " 973 " ...........................

GLASS ROCK, SOUTH ALONG BALTIMORE AND OHIO RAILROAD, TO CARTHON.

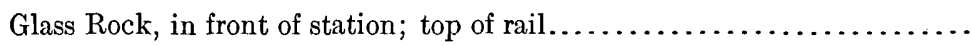

Chalfants station, 33 feet northeast of center of road crossing, in southwest corner of field of N. S. Axline; iron post stamped "Prim. Trav. Sta. No. 52"

Chalfants, at road crossing; top of rail.

850.732

(1.............................

(a) " near front entrance to Reformed Church; aluminum tablet stamped " 1091 "

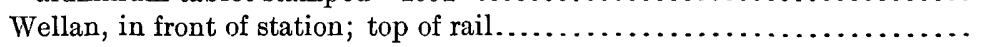

THURSTON QUADRANGLE.

Union station, West along baltimore aNd ohio rallroad, to pataskala; thence south along HIGHWAY, TO HARLEY STATION.

Outville, 260 feet south of station, in coping stone of small bridge; aluminum tablet stamped " 1070 "

Pataskala, 1.5 miles east of, northwest of road crossing, about 60 feet north of track, in southeast corner of field of Edward Condit; iron post stamped "Prim. 'Trav. Sta. No. 35".

Pataskala, in front of station; top of rail...................... 005.9

Etna, at northeast corner of Methodist Church; aluminum tablet stamped

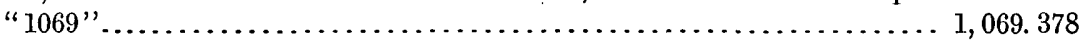

Etna, 3 miles south of, in foundation of John Weaver's barn; aluminum tablet stamped " 1003 "................................... 1,002. 704

Ritter schoolhouse, 400 feet north of, in southwest corner of abutment of small iron bridge; aluminum tablet stamped " 880 "................ 
UNION STATION, SOUTH ALONG HIGWAY, TO THURSTON.

Union station, 2 miles south of, 500 feet west of road, in foundation of small house of S. Buckman; aluminum tablet stamped " 1006 "'............ 1, 005. 516

Luray, in doorstep of German Lutheran Church; aluminum tablet stamped " 925 ".

Millersport, northeast of bridge, 47 feet due west of east rail, in south part of lot owned by Pence \& Swisher; iron post stamped "Prim. Trav. Sta.

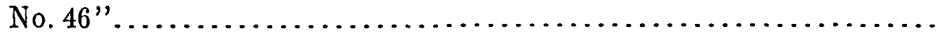

THURSTON, SOUTH ALONG HIGHWY, TO POINT 3 MILES SOUTH OF PLEASANTVILLE; THENCE WEST TO NEAR CARROLL; THENCE NORTH TO HARLEY STATION.

Thurston, 3.2 miles south of, in sandstone abutment at southwest corner of bridge; aluminum tablet stamped " 885 ".

Pleasantville, 3.14 miles south of, at east side of road at crossroads, in brick wall of schoolhouse; aluminum tablet stamped " 1027 "............. 1, 027. 237

Dumontville, in sandstone coping of stone culvert on east side of pike; aluminum tablet stamped " 1008 ".......................... 1, 008. 156

Dumontville, 1.74 miles west of, road on north, in sandstone abutment of highway bridge; aluminum tablet stamped " 886 ". ...............

Carroll, in sandstone wing wall at southeast corner of bridge over canal;

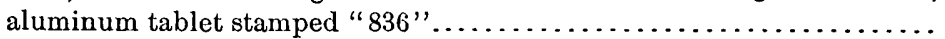

Carroll, 2.56 miles north of, road fork on east, in sandstone abutment at northeast corner of bridge; aluminum tablet stamped " 811 "..........

NEW LEXINGTON QUADRANGLE.

REHoboth, SOUTH ALONG THE OHIO CENTRAL AND THE ZANESVILLE AND WESTERN RAILWAY LNES, TO GLOUSTER.

Rehoboth, 1,150 feet south of, in south abutment east side of covered bridge; aluminum tablet stamped " 894 ".

894. 336

New Lexington, 0.3 mile north of court-house, 40 feet south of Cincinnati and Muskingum Valley Railroad, at northwest corner of scales; top of bolt head.

New Lexington, school yard; stone post marked "U. S. C. 1904 \& G. S."..

New Lexington, on north side of foundation of court-house, 5 feet from northeast corner; aluminum tablet stamped "Prim. Trav. Sta. No. 1, 958 ".

942.405

New Lexington, 1.4 miles south of, at first tunnel south of Lexington, on stone on east side of railroad; chisel marks......................

Moxahala, in front of station, at north end of platform; tọp of east rail....

Moxahala, 860 feet south of station, in east side of south abutment of iron bridge; aluminum tablet stamped " 829 ".

Rendville, 0.3 mile south of Ohio Central Railway station, in east side of south abutment of railroad bridge; aluminum tablet stamped " 752 "......

Corning, in foundation of Ohio Central Railway station, on west side, at sixth guard post from north end; aluminum tablet stamped " 728 ".....

Corning, 2.4 miles south of, 100 feet north of road crossing, in east side of south abutment of iron bridge; aluminum tablet stamped " 711 ."........

Burr Oak, 0.5 mile north of, on north side of east abutment of county bridge

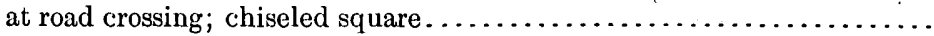

Burr Oak, in front of station; top of rail...........................

Palos, in foundation of turntable of Marietta, Columbus and Cleveland Railroad; aluminum tablet stamped " 699 ".

827.

828. 457

751,464

728. 234

711. 4006

699.51

698.4

698. 990 
Glouster, 1 block west of Main street, south of livery stable formerly owned by Carpenter \& Morgan, in northeast corner of county bridge over Sunday Creek; aluminum tablet stamped "682" (set in 1907). . . . . . . . . .

Trimble station, in northeast corner of curbing of station platform, chiseled square; painted " 679.3 ".

Feet.

681. 282

679.33

JUNCTION CITY, SOUTHEAST AND SOUTH TO BRISTOL.

Junction City, 3.65 miles southeast of, 50 feet west of road crossing, in southeast abutment of wagon bridge over stream; aluminum tablet stamped " 879 ".

Bristol, in front of station at road crossing; top of rail.

CROOKSVILLE, SOUTH TO CORNING; THENCE WEST TO DIXIE.

Crooksville, 60 feet south of Cincinnati and Muskingum Valley Railroad station, on west end of north abutment of iron railroad bridge; chiseled square marked " 752 ".

Tropic, 260 feet south of station, west of railroad, in west end of south abutment of iron railroad bridge; aluminum tablet stamped " 767.1908 ".....

Misco, in front of station; top of rail (marked " $780 ")$. . . . . . . . . . . . .

Misco, 2.04 miles south of, 125 feet west of railroad, at southwest corner of wagon bridge over creek, in sandstone outcrop on west side of creek; alu-

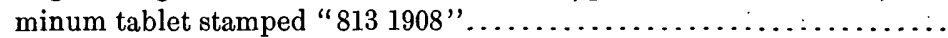

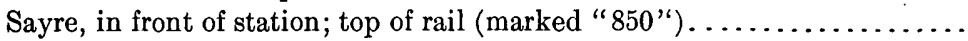

Sayre, 2.48 miles south of, west of railroad, 15 feet north of road crossing, 2 feet north of cattle-guard, in limestone rock; aluminum tablet stamped "915 1908".

Rendville, 0.3 mile north of, in southeast corner of south abutment of Ohio Central iron bridge; aluminum tablet stamped " 752 ". .............

Corning, in east side foundation of Ohio Central Railway station; aluminum

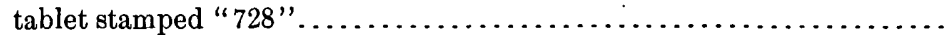

Corning, 2.15 miles west of, north of tracks, 50 feet east of east end of tunnel; point on sandstone rock marked " 869 ".

Congo, 75 feet northeast of station, 50 feet east of railroad, 5 feet south of entrance to butcher shop, in west foundation wall of Sunday Creek Company's store No. 108; aluminum tablet stamped " 833 1908"...........

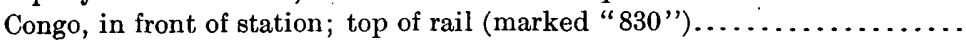

Drakes, in front of station; top of rail. . . . . . . . . . . . . . . . . . . . .

Buckingham, in front of station; top of rail (marked " 747 ") . . . . . . . . .

Hemlock, 45 feet south of 'post-office, east of road, 160 feet south of railroad, at northeast corner of high way bridge over creek, in sandstone abutment; aluminum tablet stamped "765 1908".

Shawnee, 100 feet north of Zanesville and Western station, in northwest abutment of highway bridge over creek; aluminum tablet stamped "803 1908".

Shawnee, in front of Baltimore and Ohio station; top of rail (marked

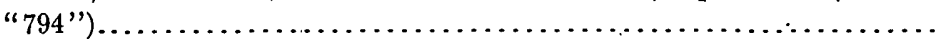

McCuneville, road crossing at station; top of rail (marked " 775 ")..........

McCuneville, at northwest edge of public school; iron post stamped "Prim. Trav. Sta. No. 2 778-1907".

767. 171

779. 5

812. 344

849.4

869. 06

833.512

830.6

740.7

747.5

764. 835

803. 001

794. 2

775. 3

778. 489

McCuneville, 1.18 miles northwest of, 115 feet north of railroad crossing, cn east corner of stone in south abutment of iron highway bridge; cross

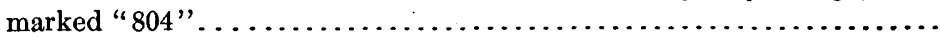
old bench mark on west corner of same abutment marked " $B$. M. $804.9 "$ ". 
Dixie, in front of station; top of rail (marked " 857 ") ..................

Feet.

Dixie, at southwest corner on south side of Upson Coal Company's store; aluminum tablet stamped " 861 " (U. S. G. S. 1907)...................

857. 4

860.834

,

CROOKSVILLE, WEST, VIA NEW LEXINGTON, TO JUNCTION CITY.

Crooksville crossing of the Cincinnati and Muskingum Valley Railroad and the Zanesville and Western Railway at milepost "T-30"; top of rail

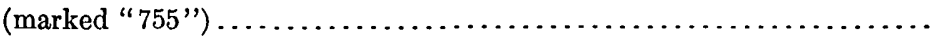

Crooksville, 1.2 miles southwest of, at milepost " $\mathrm{T}-31$ " and section post " $8-9$," on southeast corner of east abutment of sandstone culvert; chiseled square marked " 762 ". . . . . . . . . . . . . . . . . . . . . . . .

McLuney, 30 feet south of tracks, 100 feet north of front entrance to store kept by Baughman \& Blackburn, 25 feet west of house occupied by Mr. Blackburn, on land owned by Chas. Myers; iron post stamped "Prim. Trav. Sta. No. $65-805 "$. . . . . . . . . . . . . . . . . . . . . . . . . .

McLuney, in front of station; top of rail (marked " 808 ").............

MćLuney, 2.61 miles west of, at Goston flag station, 5 feet east of milepost "T-35"; top of rail section driven in ground (marked " $921 ") . . . . . .$.

McLuney, 2.93 miles west of, 0.3 miles west of Goston siding, north of railroad, in center of sandstone culvert 38; aluminum tablet stamped "911-1908".

McLuney, 4.61 miles west of, at milepost "T-37", on north end of east steel beam of railroad bridge 40 ; cross marked " 875 ".................

New Lexington, on northwest corner of platform at union station; chiseled

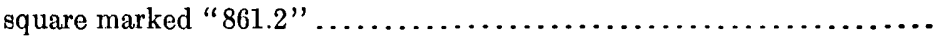

New Lexington, 1.42 miles west of union station, 20 feet east of railroad crossing, in west end of south abutment of small rock culvert; aluminum

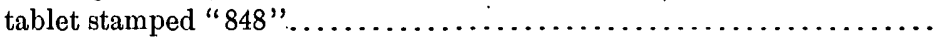

754.6

761.98

805. 259

807.8

920.55

911. 310

874. 88

861. 22

848.020

\section{LOGAN QUADRANGLE.}

RUSHVILLE, SOUTH ALONG OHIO CENTRAL RAILWAY, TO BREMEN; TIENCE EAST ALONG CINCINNATI AND MUSKINGUM VALLEY RAILROAD, TO JUNCTION CITY; THENCE NORTH ALONG BALTIMORE AND OHIO RAIL ROAD, TO CARTHON.

Rushville, 3.14 miles south of, west side of railroad, in stone abutment of culvert; aluminum tablet stamped " 821 "....................

Bremen, in north side of front doorstep of schoolhouse, 5 feet from tread

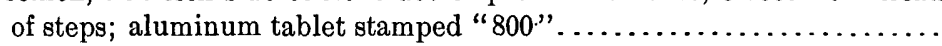

Bremen, in front of Cincinnati and Muskingum Valley Railroad station; top of rail

799.6

Bremen, 3.95 miles east of, north side of railroad, in north abutment of stone culvert; aluminum tablet stamped " 813 ".

Junction City, 150 feet northwest of station, 20 feet east of street near Cincinnati and Muskingum Valley Railroad right of way; iron post stamped "Prim. Trav. Sta. No. 66 829".

Junction City, in front of Baltimore and Ohio Railroad station; top of rail.

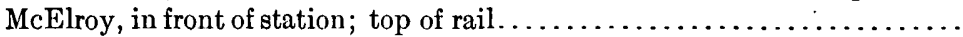

McElroy, 0.73 mile north of, 50 feet east of railroad, in northeast abutment of iron bridge at crossroads; aluminum tablet stamped " 830 "..........

829.595

BREMEN, WEST ALONG RAILROAD, TO NORTH BERNE.

Bremen, 1.8 miles west of, road crossing 100 feet east of bridge, in sandstone abutment at northeast corner of railroad bridge; aluminum tablet stamped " 803 ". 
BREMEN, SOUTH ALONG HIGHWAY AND HOCKING VALLEY RAILROAD, TO LOGAN.

Bremen, 2.96 miles south of, 281 feet north of forks of road, in stone foundation of Joseph Boch's stable; aluminum tablet stamped " 991 ".........

Bremen, 6.65 miles south of, in stone foundation of Christ. Kunkler's stable; aluminum tablet stamped " 1038 ".

Bremen, 8.93 miles south of, in stone foundation at southeast corner of bridge; aluminum tablet stamped " 838 ". ......................

Logan, 2.5 miles north of, at forks of road, in stone at southwest corner of foundation of bridge; aluminum tablet stamped " 743 ". ............

Logan, in water table near end of portico at northwest corner of court-house, 1 foot from front face; aluminum tablet stamped " 741 "............

740.345

BRISTOL, SOUTH ALONG BALTIMORE AND OHIO RAILROAD AND HIGHWAY, TO BAIRDS FURNACE; THENCE WEST ALONG HOCKING VALLEY RAILROAD, TO WEBB SUMMIT.

Dixie, in front of station; top of rail. . . . . . . . . . . . . . . . . . .

Dixie, 0.03 mile south of, in stone foundation on south side of the Upson Coal Mining Company's store; aluminum tablet stamped " 861 ".......

Dixie, 4.2 miles south of, in stone abutment at northeast corner of iron bridge; aluminum tablet stamped " 749 ".

858.4

860.834

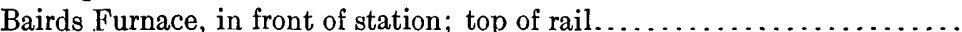

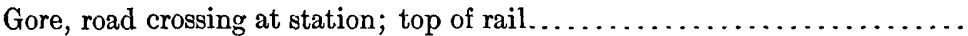

Gore, 200 feet north of station, 100 feet east of forks of road, in stone foundation at southeast corner of iron bridge; aluminum tablet stamped " 768 ".

Gore, 3.65 miles west of, 135 feet north of track, at road crossing, in southwest abutment of iron bridge; aluminum tablet stamped " 760 ".........

Webb Summit, in front of station; top of rail.....................

761. 6

768. 033

759. 492

788.4

BAIRdS FURNACE, SOUTH ALONG HOCKING VALLEy RAILROAD AND HigHWAY, TO A POINT 6.4 MiLES SOUTHEAST OF LOGAN.

Kachelmacher, 730 feet east of, in north side of west abutment of iron bridge; aluminum tablet stamped " 704 "....................

Kachelmacher, 2.31 miles southwest of, in stone doorstep of schoolhouse; aluminum tablet stamped " $792 "$ "...........................

791. 154

ENTERPRISE, SOUTHEAST ALONG HOCKING VALLEY RAILROAD, TO HAYDENVILLE.

Enterprise, at station, 50 feet west of track, in sandstone platform of large

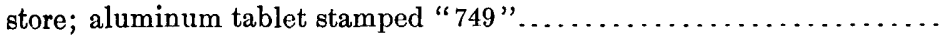

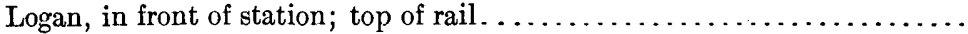

Logan, 4.1 miles southeast of, 244 feet north of railroad, 125 feet southwest of house on north side of road, in north abutment of stone culvert across highway; aluminum tablet stamped " $719 " . . \ldots \ldots \ldots \ldots \ldots \ldots .$.

727.3

718. 345

LANCASTER QUADRANGLE.

Near pleasantVille, southwest along highway, to lancaster; thence northwest along HOCKING VALLEY RAILROAD, TO CARROLL.

Pleasantville, 5.41 miles southwest of, 60 feet from road fork on west, on west side of road, in sandstone foundation of Bushy schoolhouse;

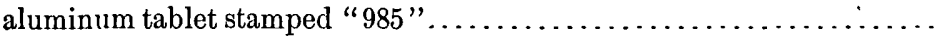

Lancaster, in sandstone coping to stoop on west side of city post-office; aluminum tablet stamped " 845 "

984.433

Hooker, 350 feet northwest of station, on north side of road near southeast corner of field of Mike Vase, 29 feet southwest of southwest corner of house; iron post stamped "Prim. Trav. Sta. No. 48"...............

Hooker, 3 miles west of, west of crossroads, near apple tree on top of steep bank in east part of field owned by Jacob Bookmon; iron post stamped “Prim. Trav. Sta. No. 49"................................. 1,021. 203 
LANCASTER, EAST ALONG CINCINNATI AND MUSKINGUM VALLEY RAILROAD, TO NORTH BERNE.

Lancaster, 3.3 miles east of, 30 feet from track at crossing, in sandstone abutment of small wooden culvert on north side of railroad; aluminum tablet stamped " 832 ".

LANCASTER, SOUTHEAST ALONG HOCKING VALLEY RAILROAD, TO ENTERPRISE.

Lancaster, 4.22 miles south of, in sandstone abutment at northeast corner of railroad bridge; aluminum tablet stamped " 791 ".

790. 782

Sugar Grove, 0.19 mile south of, in sandstone abutment at northeast corner

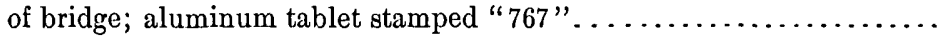

Rockbridge, in stone stoop of schoolhouse; aluminum tablet stamped " 753 "

LANCASTER, SOUTHWEST ALONG CINCINNATI AND MUSKINGUM VALLEY RAILROAD, TO AMANDA.

Lancaster, 3.58 miles southwest of, in sandstone abutment at northwest corner of bridge; aluminum tablet stamped " 958 "................

Lancaster, 6.42 miles southwest of, 600 feet northeast of road crossing, north side of track, in top of stone culvert; aluminum tablet stamped " 995 ".

Lancaster, 8.23 miles southwest of, on north side of railroad, on sandstone abutment; chisel mark.

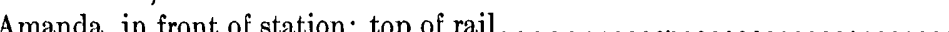

Amanda, 0.75 mile east of, on east side of pike at fork to west, south of culvert; iron post stamped "Prim. Trav. Sta. No. 7"....

ENTERPRISE, WEST ALONG HIGHWAY, TO POINT 3.8 MILES WEST OF BUENA VISTA; THENCE NORTI TO AMANDA.

Enterprise, 5.6 miles west (?) of, 60 feet from road fork on south, on south side of road, in sandstone foundation of large barn; aluminum tablet stamped " 1070 ".

Enterprise, 8.6 miles west of, road fork on north, in sandstone foundation of abutment at northeast corner of small wooden bridge; aluminum tab-

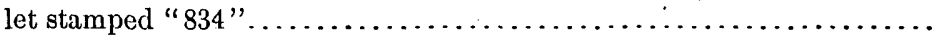

Enterprise, 11.72 miles west of, 2,020 feet north of road forks, on west side of road, in sandstone abutment of iron bridge; aluminum tablet stamped " 812 ".

Middle Fork, in sandstone wing wall of iron bridge; aluminum tablet stamped " 887 "

886.862

Middle Fork, 3.8 miles west of by 3 miles north of, 220 feet west of road on east, in sandstone foundation of house of Samuel Harvey; aluminum tablet stamped " 1099 ".

Amanda, 2.69 miles southeast of, at road fork on southwest, in abutment at northwest corner of small bridge; aluminum tablet stamped " $860 " . .$. .

NEAR MIDDLE FORK.

Middle Fork, 3.8 miles west of by 0.7 mile south of, in sandstone abutment of small wooden bridge over mouth of small run on west; aluminum tab-

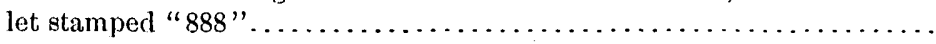

\section{CIRCLEVILLE QUADRANGLE.}

POINT SOUTHWEST OF MIDDLE FORK, SOUTHWEST, VIA STRINGTOWN, TO ADELPHIA.

Stringtown, in sandstone post at southwest corner of Wm. Ballard's pasture; aluminum tablet stamped "Prim. Trav. Sta. No. 9 821".......... 
PUT-IN-BAY QUADRANGLE.

OTTAWA COUNTY.

The elevations in the following list are based on the assumption that the elevation of Lake Erie at Put-In Bay August 29, 1901, was 571.7 feet above mean sea level, in accord with the elevation at Cleveland by the 1907 adjustment. The leveling was done in 1901 by A. F. Freundburg.

\section{PUT-IN-BAY QUADRANGLE.}

Put-In-Bay, South Bass Island, at north corner of Hotel Victory, in foundation 1.6 feet above ground; aluminum tablet stamped " 643 "..........

Middle Bass Island, in center of foundation on club grounds, west of pavilion; on northeast corner of square stone ....................

North Bass Island, west of post-office, at church, at northeast corner of $T$ road; highest point of limestone bowlder.......................

Sugar Island, on bottom of capstan near south dock; cross. . ........... Rattlesnake Island, 3 feet from northwest corner of stone addition to solitary frame house, 2.6 above ground; cross. . . . . . . . . . . . . . . . .

Feet.

587.26

\section{MAUMEE BAY, OAK HARBOR, AND TOLEDO QUADRANGLES. . LUCAS, OTTAWA, AND WOOD COUNTIES.}

The leveling in these quadrangles was done in 1899 by Dean Halford. TOLEDO QUADRANGLE.

Alexis, 0.6 mile north of, sec. 1, T. 9 S., R. 7 E., 0.1 mile south of MichiganOhio boundary, 1,200 feet north of Drouillard's Hotel, in face of culvert on west side of Toledo-Detroit pike; bronze tablet stamped " 586 TOLEDO"

Feet.

Sylvania, 0.25 mile east of, on Monroe street, on stone at east of center of top tier of north abutment of culvert over North Branch (of Tenmile Creek); bronze tablet stamped "TOLEDO 639".

Airline Junction, 2 miles southwest of, SW. $\frac{1}{4} \mathrm{sec} .8$, T. 3 (Twelvemile Reservation), 0.5 mile south of Lake Shore and Michigan Southern Railway, on stone pike, 0.3 mile east of crossroads, in top tier of center slot of culvert at south side of road; bronze tablet stamped "TOLEDO 624 ". .

Monclova, 2 miles south of, center of sec. 17, T. 1 (Twelvemile Reservation), on road 0.75 mile south of Wabash Railroad, on top of pier at west end of north abutment of bridge over branch; bronze tablet stamped "TOLEDO 642 " a

Holland, 0.2 mile south of station, sec. 15, T. 2 (Twelvemile Reservation), on top tier at west end of north pier abutment of bridge over Wolf Creek;

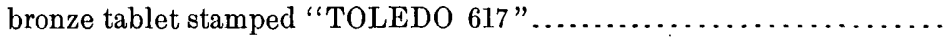

Lime City, sec. 14, T. 4 (Twelvemile Reservation), opposite schoolhouse, in northwest corner of foundation of church; bronze tablet stamped "TOLEDO 647 ".

Perrysburg, 1 mile south of, sec. 7, T. 4 (Twelvemile Reservation), in top tier at east end of south pier abutment of bridge over Grassy Creek; bronze tablet stamped " 636 TOLEDO". over Cedar Creek; bronze tablet stamped "TOLEDO 619 "............ 
Walbridge, 0.5 mile north of, in face of north pier abutment of bridge over branch of Cedar Creek; bronze tablet stamped "TOLEDO 614".......

Ironville, 2.5 miles east of, in center of sec. 26 , T. 9 S., R. 8 E., 2 miles northwest of Momeneetown, northwest eorner of $T$ roads, in front of Sayers house, in slab of culvert; bronze tablet stamped "TOLEDO $587 "$

Feet.

615. 158

Curtice, 1 mile south of, in west end of south pier of abutment of bridge over Crane Creek; bronze tablet stamped "596 TOLEDO".

587.712

597.021

Genoa, 1 mile west of, at northwest corner of crossroads, on stone road, at northeast corner of culvert; bronze tablet stamped "TOLEDO 626 "....

Genoa, 5.75 miles west of, 2 miles east of Stony Ridge, on stone pike in south foundation of D. F. Mann's residence; bronze tablet stamped "TOLEDO 634".

634.328

Trowbridge, 1 mile east of, 0.25 mile south of northwest corner of sec. 9 , T. 7 N., R. 14 E., in east end of south pier abutment of highway bridge over Turtle Creek; bronze tablet stamped "TOLED0 582".

Genoa, 3 miles east of, in west end of north pier abutment of bridge over Toussaint Creek; bronze tablet stamped "599 TOLEDO"............

600.097

OAK HARBOR QUADRANGLE.

Limestone, 2 miles northeast of, east side of sec. 13, T. 7 N., R. 14 E., 600 feet south of creek road, 0.3 mile east of Daniel Muggy's house, in west end of north pier abutment of bridge over Toussaint Creek; bronze tab-

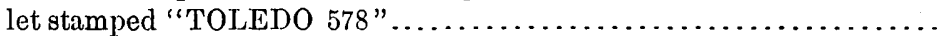

Lacarne, 1.5 miles west of, near northeast corner of sec. 1, T. 6 N., R. 15 E., on south side of road to Oak Harbor, in top tier of culvert; bronze tablet stamped "TOLEDO 579 ".

Oak Harbor, on east end of second tier of second abutment from north end of bridge over Portage River; bronze tablet stamped "TOLEDO 581"..

Rocky Ridge, 0.75 mile south by 0.5 mile east of, on east side of sec. 35 , T. 7 N., R. 14 E., 0.25 mile north of Genoa-Oak Harbor road, in west end of south pier of bridge over branch; bronze tablet stamped "TOLEDO $596 "$

BELLEVUE, BOWLING GREEN, BLMORE, FINDLAY, FOSTORIA, FREMONT, SANDUSKY, AND VERMILION QUADRANGLES.

ERIE, HANCOCK, HURON, LORAIN, SANDUSKY, SENECA, AND WOOD COUNTIES.

The leveling was done in 1901 as follows: On a double-rodded control line run from Tontogany east to Old Woman Creek, in Bowling Green, Elmore, Fremont, Bellevue, and Sandusky quadrangles, and additional work in the Fremont, Bellevue, and Sandusky quadrangles by D. C. Witherspoon and A. C. Freundburg; and in the Bowling Green, Elmore, Fostoria, and Findlay quadrangles by J. A. Belford and Duncan Hannegan. The continuation of the double-rodded line to North Amherst, crossing Vermilion quadrangle, and the remainder of the work in Vermilion quadrangle was done by Dennis D. Doty. 


\section{BOWLING GREEN QUADRANGLE.}

TONTOGANY, SOUTHEAST ALONG RAILROAD AND HIGHWA, TO NEW ROCHESTER (DOUBLE-RODDED.LINE).

Tontogany, at southeast corner of Main and Broad streets, west side of entrance to Waltz's store (1894); northwest corner of iron plate under column, being top of a surface 78 inches square. (Coast and Geodetic

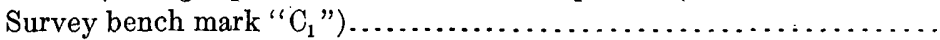

Bowling Green, in southwest corner of court-house, on top of limestone post; bronze meridian tablet stamped "695 TOLEDO"..............

Bowling Green, 3 miles east of, northeast abutment of iron bridge over North Branch Portage River; chiseled square.....................

New Rochester, 0.2 mile east of, northeast corner of stone abutment of bridge over Middle Branch Portage River; chiseled cross.............

Feet.

669.510

661. 10

BOWLING GREEN, NORTH ALONG ELECTRIC LINE, TO ROACHTON.

Sugar Ridge, 2 miles northwest of, northeast corner of sec. 36, T. 6 N., R. $10 \mathrm{E}$, east side of railway, at southwest corner of west abutment of iron bridge over ditch; aluminum tablet stamped " 666 TOLEDO"........

Bend station, at north end of switch; top of east rail...................

AT HULL PRAIRIE (SET FROM COAST SURVEY BENCH MARK ON SAME BRIDGE).

Hull Prairie, about 200 feet east of station, in southeast quarter of stone culvert on first step below bridge seat; aluminum tablet stamped " 660 TOLEDO"

TONTOGANY, SOUTH 2 MILES (SINGLE-SPUR LINE).

Tontogany, 2 miles south of, south side of sec. 17, T. 5 N., R. 10 E., in north end of west stone abutment of small iron bridge over ditch; aluminum

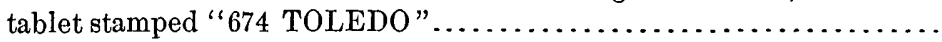

BOWLING GREEN, SOUTH ALONG ELECTRIC LINE, TO DUCAT; THENCE WEST TO WINGSTON.

Wingston, 0.7 mile northeast of, east side of sec. 28 , T. 3 N., R. 10 E., in corner of stone abutment at southwest corner of bridge over Middle Branch Portage River; aluminum tablet stamped "689 TOLEDO" $b$...

DUCAT, SOUTHEAST TO MUNGEN; THENCE EAST AND NORTH TO NEW ROCHESTER.

Mungen, in front of station; top of rail.

687.9

Mungen, 0.5 mile southeast of, north side of sec. 31, T. 4 N., R. 11 E., in west stone abutment at southwest corner of bridge over Middle Branch Portage River; aluminum tablet stampè " 689 TOLEDO"...........

West Millgrove, 3 miles northwest of, south side of sec. 30, T. 4 N., R. 12 E., at southeast corncr of wooden bridge over South Branch Portage River, in stone abutment; aluminum tablet stamped "692 TOLEDO".......

NEW ROCHESTER, NORTH 6.5 MLLES; THENCE EAST TO LUCKEY.

Luckey, 1 mile west by 0.5 mile north of, east side of sec. 19, T. 6 N., R. 12 $\mathrm{E}$., in north end of west abutment at northwest corner of iron bridge over ditch; aluminum tablet stamped " 649 TOLEDO".............. 
ELMORE QUADRANGLE.

NEW ROCHESTER, ALONG NAPOLEON-FREMONT ROAD, VIA HELENA, TO MUDDY CREEK (DOUBLE-RODDED LINE).

Woodside, 0.5 mile west of, northeast corner of sec. 33 , T. 5 N., R. 12 E., southwest corner of crossroads, in south side of west abutment of culvert over ditch; aluminum tablet stamped " 669 TOLEDO"..............

Helena, on east side, near southwest corner of Weaver's store, north side of road; aluminum tablet stamped "699 TOLEDO".

Helena, 2 miles east of, on south end of west abutment of iron bridge over Muddy Creek, about 1 foot south of iron bed plate; chiseled cross.......

LUCKEY, SOUTH VIA BRANDER, TO RISING SUN.

Pemberville, 1 mile east of, east side of sec. 11, T. 5 N., R. 12 E., in north end of stone abutment at southeast corner of iron bridge over Portage River; aluminum tablet stamped "644 TOLEDO"

- NEAR RISING SUN, TO GIRTON; THENCE NORTH TO ROLLERSVILLE.

Rising Sun, 1 mile west of, southeast corner of sec. 26, T. 4 N., R. 12 E., at northeast corner of crossroads, in center of stone in culvert; aluminum

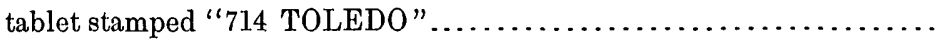

ROLLERSVILLE, NORTH TO WOODVILLE; THENCE EAST AND SOUTH TO HELENA.

Woodville, in southeast abutment, first step of bridge over Portage River;

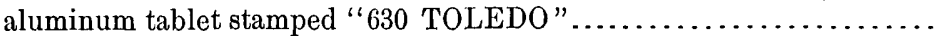

Hessville, 1.5 miles northwest of, southeast corner sec. 6, T. 5 N., R.14 E., at Swartzman crossing of Fremont Electric Railway, at northwest corner of south side of culvert; aluminum tablet stamped "636 TOLEDO"....

heleNa, SOUth 5 miles, via Millersville; thence West to girton.

Millersville, 3 miles south of, west side of sec. 29, T. 4 N., R. 14 E., 2.3 miles north of Kansas, in southeast pier of iron bridge over creek; aluminum tablet stamped "699 TOLEDO"..........................

NEAR RISING SUN. $a$

Rising Sun, 1 mile south of, at junction of county and township lines, in southwest abutment of bridge over creek; chiseled square.............

FOSTORIA QUADRANGLE.

NEAR LONGLEY. $a$

Longley, 0.8 mile south of, in southeast abutment of iron bridge over creek;

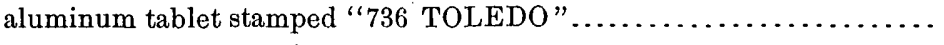

NEAR LONGLEY, EAST 10 MHES AND NORTH TO NEAR KANSAS.

Bascom, 5.3 miles north of, in southwest abutment of iron bridge over Plum River; aluminum tablet stamped " 725 TOLEDO".

Kansas, 1 mile south of, at southwest corner of road fork, in stone abutment; chiseled' cross. 
AT FOSTORIA (BENCH MARYS OF THE COAST AND GEODETIC SURVEY).

Fostoria, corner Main and Center streets, in southwest corner of First National Bank Building, on east side of Center street entrance, in vertical surface of the water table; tablet $\left(A_{6}\right)$ of red metal..............

Fostoria, at southeast corner of Tiffin and Union streets, 1 meter from curb, hole 25 centimeters square and 4 millimeters deep, cut in top of a stone post 4 feet long and 7 inches square, projecting 6 inches above ground; top lettered U.S.B.M.; bottom of hole $\left(B_{6}\right) \ldots \ldots \ldots \ldots \ldots \ldots \ldots \ldots$.

Feet.

781.071

Bascom, 5 miles north of, at southwest corner of road forks, in stone culvert; chiseled cross.

728.87

BASCOM, SOUTH 5.2 MILES; THENCE WEST 6.2 MILES; THENCE NORTI TO FOSTORLA.

Bascom, 0.3 mile south of, south of cemetery, in southwest abutment of iron bridge over creek; aluminum tablet stamped " 766 TOLEDO"......

Bascom, 5.3 miles south of, 100 yards west of schoolhouse at crossroads, in northwest abutment of stone culvert over creek; aluminum tablet stamped "805 TOLEDO".

New Riegal, 1 mile north by 2 miles west of, at crossroads, in stone step of schoolhouse; chiseled cross.

NEAR ALVADA.

Alvada, 1 mile north of, at crossroads, in step of schoolhouse; chiseled

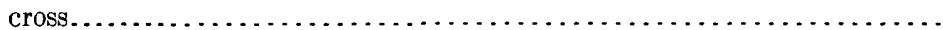

Alvada, 2 miles south of, in stone at northwest abutment of iron bridge over creek; aluminum tablet stamped "815 TOLEDO"

\section{FINDLAY QUADRANGLE.}

NEAR BLOOMDALE, VIA OIL .CENTER, TO NEAR NORTH BALTIMORE.

Bloomdale, 1.5 miles east of, sec. 31, T. 3 N., R. 12 E., on southeast abutment of iron bridge; aluminum tablet stamped " 740 TOLEDO".

740. 625

Bloomdale, on main street, at northeast corner of hardware store; square cut in stone step.

Oil Center, south side of, sec. 18, T. 3 N., R. 11 E., in northwest abutment of iron bridge over Rocky Ford; copper bolt stamped "709 TOLEDO"...

North Baltimore, 1.3 miles east of, in west side of doorstep at schoolhouse;

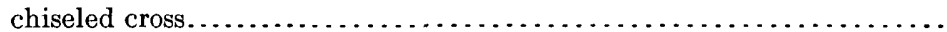

North Baltimore, 0.5 mile south of, sec. 35 , T. 3 N., R. 10 E., in southeast abutment of bridge over creek; bronze tablet stamped " 726 TOLEDO"..

GALATEA, SOUTH TO FINDLAY.

Findlay, in north front of court-house, east of north entrance; aluminum tablet stamped "779 TOLEDO"

NEAR FINDLAY (ON CIRCUITS EAST AND WEST OF).

Findlay, 5:5 miles east of, sec. 24 , T. 1 N., R. 11 E., in stone abutment at northeast corner of bridge over The Outlet 0.5 mile east of its junction with Blanchard River; aluminum tablet stamped "786 TOLEDO"....

Findlay, 4 miles west of, sec. 21 , T. 1 N., R. 10 E., in east corner of southwest abutment of iron bridge over small creek; aluminum tablet stamped "771 TOLEDO" 
FREMONT QUADRANGLE.

MUDDY CREEK, EAST ALONG highWAY AND RAILROAD, to CLYDE (DOUBLE-RODded LINE).

Helena, 5.5 miles east of, southwest corner of iron bridge over Muskellunge Feet.

Creek, on abutment 4 inches south of iron beam; chiseled cross......... 640. 72

Fremont, in south face of jail wall, near southeast corner of building, 5 feet above ground; aluminum tablet stamped " 636 TOLEDO".

636.118

Clyde, 2.5 miles west of, sec. 9 , T. 4 N., R. 16 E., in northeast abutment of bridge over creek, at Maumee pike; aluminum tablet stamped "637

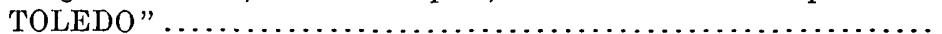

FREMONT, NORTH TO KINGSWAY (DOUBLE-RODDED LINE).

Kingsway, 1.5 miles east of, 0.3 mile west of quarter corner at east side of sec. 3, T. 5 N., R. 15 E., at crossroads, in foundation of north wall at northeast corner of Methodist Church; aluminum tablet stamped " 588

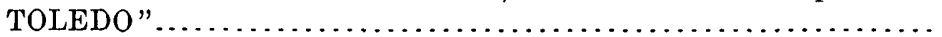

\section{BELLEVUE QUADRANGLÈ.}

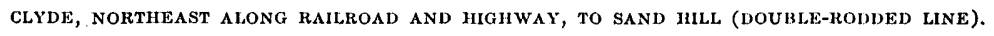

Townsend, NE 1 sec. 34, T. 5 N., R. 17 E., on north ridge road; at northeast corner of foundation of schoolhouse; aluminum tablet stamped " 678 TOLEDO"

Meyers, southwest of, north side of sec. 2, T. 5 N., R. 24 W., in face of abutment wall at southwest corner of bridge over creek; aluminum tablet stamped "694 TOLEDO".

Sand Hill, 0.5 mile west of, sec. 2, T. 5 N., R. 23 W., at northwest corner of white plastered brick church, in face of water table; aluminum tablet stamped "734 TOLEDO".

POINT 4 MILES NORTHEAST OF CLYDE, SOUTHEAST tO BELLEVUE (CHECKED LINE).

Bellevue, at south corner of Burdette Hotel, in wall; aluminum tablet stamped "751 TOLEDO".

POINT 5 MILES NORTHEAST OF CLYDE, NORTH TO NEAR VICKERY AND RETURN.

Vickery, 1 mile west of, north side of sec. 24 , T. 5 N., R. 16 E. (Riley Township), in southeast abutment of bridge over Pickerel Creek; bronze tablet stamped " 588 TOLEDO" . . . . . . . . . . . . . . . . . . . . . . .

588.514

SANDUSKY QUADRANGLE.

SAND HILL, EAST TO BERLIN HEIGHTS (DOUBLE-RODDED LINE).

Prout station, sec. 2, T. 5 N., R. 23 W. (Oxford Township), 500 feet east of Baltimore and Ohio Railroad tracks, in east wall at northeast corner of frame schoolhouse (sub-dist. 6); aluminum tablet stamped "700 TOLEDO"

Avery, 0.5 mile north of, near quarter corner at south side of sec. 2 , T. 5

N., R. 22 W., at Spears corners, on west face of foundation at northwest corner of schoolhouse, abouf 1 foot above ground; bronze tablet stamped

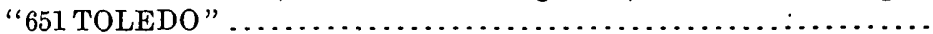

Berlin Heights, 2 miles west of, iron bridge over branch of Old Woman Creek, on stone at top of southeast abutment; bronze tablet stamped "608 TOLEDO". 
BERLIN HEIGHTS, NORTHWEST TO SHINROCK (SMALL CIRCUIT VIA OLD WOMAN CREEK).

Shinrock, at northwest corner of C. Hoffman's store; aluminum tablet stamped "627 TOLEDO".

PROUT STATION, NORTH, THROUGH PERKINS TOWNSHIP, TO SANDUSKY.

Sandusky, 2 miles south of NE. $\frac{1}{4}$ SE. $\frac{1}{4}$, sec. 3 , T. 6 N., R. 23 W., in water table at northwest corner of schoolhouse; aluminum tablet stamped "616 TOLEDO".

Sandusky, in south side of government building, at southeast corner; aluminum tablet stamped "597 TOLEDO"

AVERY, SOUTH ALONG HIGHWAY, VIA MILAN, TO NORWALK TOWNSHIP.

Milan, 2 miles south of, in northern part of sec. 3 , T. 4 N., R. 22 W., about 500 feet south of Huron-Erie county line, on top of south end of retaining wall of filled road over creek; bronze tablet stamped "624 TOLEDO"

\section{VERMILION QUADRANGLE.}

BERLIN HEIGHTS, VIA ASHMONT AND VERMILION, TO NORTH AMHERST (DOUBLE-RODdED LINE).

Berlin Heights, corner Main and Hotel streets, at southwest corner of stone window sill of Lippus \& Fowler's store; bronze tablet stamped "777 TOLEDO".

Ashmont, 700 feet east of station, 300 feet south of railroad, in southeast corner of wagon bridge; aluminum tablet stamped "614 TOLEDO"....

Vermilion, in window sill at southeast corner of Davis Bros.' store; aluminum tablet stamped "595 TOLEDO".

Brownhelm, at south end of north side of railroad bridge 141; aluminum tablet stamped " 640 TOLEDO".

VERMILION, SOUTH TO BIRMINGHAM (DOUBLE-RODDED LINE).

Birmingham, on west abutment stone of bridge over Vermilion River, in south end of third stone from top and 1 foot from east edge; aluminum tablet stamped "716 TOLEDO"

BERLIN HEIGHTS, SOUTH TO COLLINS; THENCE EAST TO WAKEMAN; tHENCE NORTH TO BIRMINGHAM

Collins, in sill of center window at west side of public school; bronze tablet

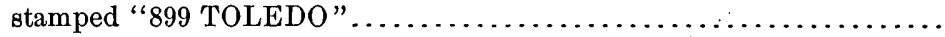

Wakeman, at west end of bridge over Vermilion River, in second stone from top, at south side; aluminum tablet stamped "861 TOLEDO".....

WAKEMAN, EAST ALONG HIGHWAY, VIA KIPTON, TO OBERLIN.

Kipton, north west corner of brick building (store and post-office), in window sill; bronze tablet stamped "857 TOLEDO $1901 " . . . \ldots \ldots \ldots \ldots . . . .$.

MARION, SYCAMORE, AND TIFFIN QUADRANGLES.

CRAWFORD, MARION, SENECA, AND WYANDOT COUNTIES.

The leveling was done in 1903 in Marion quadrangle by C. W. Marvin; in Sycamore and Tiffin quadrangles by C. W. Marvin and R. G. DeFrees. 
MARION QUADRANGLE.

WALDO, NORTH ALONG HIGHWAY, TO MONNETT.

Marion, 5 miles southeast of, SE. $\frac{1}{4}$ sec. 5, T. 6 S., R. 16 E., east end of south Feet. abutment of small iron bridge over creek, in bridge seat; bronze tablet stamped " 963 COL".

Marion, 4 miles east of, 0.2 mile north of center of sec. 29 , T. 5 S., R. 16 E., 1.5 feet east of northwest corner of Baptist Church, in foundation; bronze tablet stamped " $986 \mathrm{COL}$ ". T. 5 S., R. 16 E., Claridon Township, in foundation of, Bush schoolhouse, (district 3), 1 foot south of northwest corner; bronze tablet stamped " $1000 \mathrm{COL}$ "...

Kirkpatrick, Scott Township, sec. 15, T. 4 S., R. 16 E., one foot north of southwest corner of stone water table of schoolhouse (district 4); aluminum tablet stamped " 1013 COL"........................... 1, 014. 178

MONNETT, WEST ALONG HIGHWAY, TO MORRAL; THENCE SOUTHEAST ALONG HOCKING VALLEY RALLWAY, TO MARION.

Monnett, crossing at station; top of west rail

976.6

Monnett, near quarter corner at north side of sec. 8, T. 4 S., T. 16 E., 600 feet west of post-office, 1 foot east of northwest corner of brick schoolhouse, in stone water table; bronze tablet stamped " 979 COLUMBUS". .

Wyandot, 1.25 miles southwest of, sec. 9, T. 4 S., R. 15 E., opposite road running east, Antrim Township, 1 foot north of southeast corner of brick schoolhouse (district 2); bronze tablet stamped " 971 COL".

979.959

Morral, southeast corner of sec. 14, T. 4 S., R. 14 E., 1 foot east of northwest corner of schoolhouse; aluminum tablet stamped " $913 \mathrm{COL}$ ".

Morral, 4.19 miles south of, SE. $\frac{1}{4}$ sec. 6 , T. 5 S., R. 15 E., north abutment of bridge over highway, at southeast corner of bridge seat; bronze tablet stamped " 930 COL".

MARION, WEST ALONG RAILROAD 4 MILES; THENCE SOUTH ALONG HIGHWAY, TO GREENCAMP; THENCE EAST TO POINT NORTH OF WALDO.

Marion, 200 feet north of Union Station, 15 feet east of Hocking Valley Railway track, in stone abutment; bronze meridian tablet (southmark) stamped " 950 COL".

951.404

Marion, southwest corner of foundation cornerstone of court-house; aluminum tablet stamped " $985 \mathrm{COL}$ ".

985.991

Marion, 3 miles west of, SE. $\frac{1}{4}$ sec. 24 , T. 5 S., R. 14 E., northwest corner of east abutment of iron bridge over Little Scioto River; chiseled square....

Bryan station, SE. $\frac{1}{4}$ sec. 23, T. 5 S., R. 14 E., 650 feet south of Big Four Railroad crossing, 1 foot east of southwest corner of brick schoolhouse; bronze tablet stamped " 914 COL"

Greencamp, southwest corner of sec. 12, T. 6 S., R. 14 E., northwest corner of brick schoolhouse; aluminum tablet stamped " 919 COL".

Owens, sec. 17, T. 6 S., R. 15 E., 600 feet east of station, 1 foot east of southwest corner of brick schoolhouse; bronze tablet stamped " $953 \mathrm{COL}$ "....

Waldo, 4.5 miles northwest of, sec. 14, T. 6 S., R. 15 E., on Marion road, 1 foot south of southeast corner of house of John Mantz; aluminum tablet stamped " 985 COL". 
SYCAMORE QUADRANGLE.

MONNETT, NORTH ALONG HIGHWAY, VIA BROKEN SWORD, TO LYKENS.

Monnett, 3.1 miles north of, 100 feet east of crossroads, iron bridge over Feet. creek, at northeast corner of bridge seat on west abutment; chiseled

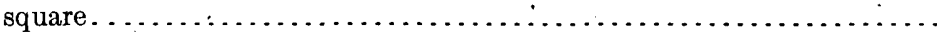

Bucyrus, 3 miles southwest of, 0.3 mile north of center of, sec. 16, T. 3 S., R. $16 \mathrm{E}$., north abutment of iron bridge over Sandusky River; southwest

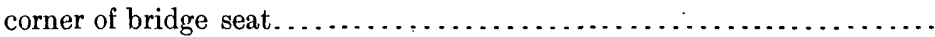

Bucyrus, 1.5 mile west of, 0.2 mile west of center of sec. 3 , T. 3 S., R. 16 E., south end of stone culvert bridge 28, of Pittsburg, Ft. Wayne and Chicago Railway, at southwest corner of coping; bronze tablet stamped "991 COL".

Bucyrus, about 3 miles northwest of, 0.2 mile south of northwest corner of sec. 34, T. 2 S., R. 16 E., small iron bridge over creek, at northeast corner of bridge seat on south abutment; square cut....................

Holmes Center, 1 mile north of, near northeast corner of sec. 16, T. 2 S., R. $16 \mathrm{E}$., southeast corner of foundation of frame dwelling of Frank Stillman; bronze tablet stamped " 987 COL".

Broken Sword, near northwest corner of sec..3, T. 2 S., R. 16 E., 800 feet south of crossroads, on west side of road, 1 foot west of southeast corner of foundation.of Seel's machine shed; bronze tablet stamped "992 COL"...

Lykens, near northeast corner of sec. 16, T. 1 S., R. 16 E., iron bridge over Sycamore River, at southwest corner of north abutment; aluminum

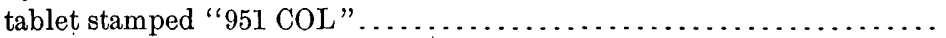

973.87

960.28

991.508

981.72

988.522

993.716

952.593

NEVADA, NORTH ALONG HIGHWAY, TO LEMERT.

Nevada, 0.25 mile east of, NW. $\frac{1}{4}$ sec. 3 , T. 3 S., R. 15 E., on northeast corner of wall of bridge 47; chisel mark (Pa. R. R. B. M.)............

Lemert, SW. $\frac{1}{4}$ sec. 1, T. 2 S., R. 15 E., in face of sandstone sill of front door of schoolhouse; aluminum tablet stamped "981 COL 1902".........

928.571

981.929

NEVADA, SOUTH ALONG HIGHWAY, TO SLINGTOWN SCHOOLHOUSE; THENCE NORTH, VIA ROCK RUN AND BELLE VERNON, TO M'CUTCHENVILLE.

Nevada, 1.25 miles east of, northeast corner of bridge 45 ; square cut ( $\mathrm{Pa}$.

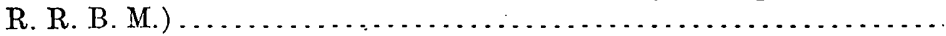
Nevada, near center of NE. $\frac{1}{4}$ sec. 4, T. 3 S., R. 15 E., in south front of foundation of school building; aluminum tablet stamped "928 COLUMBỨs"

940. 210

Nevada, 2.5 miles south of, on northwest end of stone abutment of iron bridge over Grass Run, chiseled square.

Nevada, 3 miles south by 2 miles west of, at T road south, in southeast corner of foundation of schoolhouse (district 4), Antrim Township; bronze tablet stamped " 890 COLUMBUS 1903 ".

Rock Run, SW. $\frac{1}{4}$ sec. 35, T. 2 S., R. 14 E., 5 miles west of Nevada, in foundation at east face of northeast corner of Bethel Church; bronze tab-

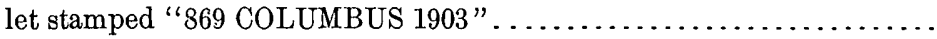

Oak Grove schoolhouse, 0.7 mile north of, NW. $\frac{1}{4}$ sec. 14, T. 2 S., R. 14 E., in southeast corner of foundation of $\mathrm{Wm}$. Schoenberger's residence; aluminum tablet stamped " 836 COLUMBUS 1903 ".

929. 311

891.043

870.001

836.705

Belle Vernon, near center of sec. 25, T. 1 S., R. 14.E., in north face of foundation at northwest corner of church; bronze tablet stamped "837 COLUMBUS $1903 "$ 
TIFFIN QUADRANGLE.

LYKENS, NORTH AND WEST ALONG HIGHWAY, VIA REPUBLIC AND BEAVER CREEK, TO OLD FORT.

Bloomville, 2 miles south of, south abutment of small iron bridge over Silver Creek, northeast corner of bridge seat, square mark . . . . . . . .

Bloomville, 2 feet north of southwest corner of town hall; aluminum tablet stamped " 932 COL".

Feet.

924.71

Bloomville, 1 mile north of, near northwest corner of sec. 10, T. 1 N., R: 16 $\mathrm{E}$., northeast corner of south abutment of iron bridge over Honey Creek;

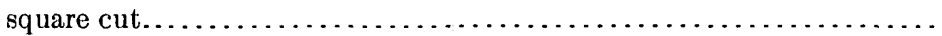

Republic, southwest corner of town hall; aluminum tablet stamped "883 COL"

Republic, about 3 miles north of, south of northeast corner of sec. 5, T. 2 N., R. 16 E., at northwest corner of south abutment of small wooden bridge

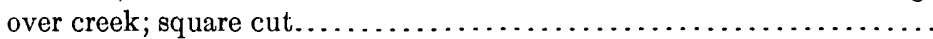

Republic, about 5 miles north of, at southwest corner of sec. $21, \mathrm{~T} .3 \mathrm{~N}$., R. 16 E., northeast of crossroads, south side of brick house of A. J. Rule, in foundation of bay window; bronze tablet stamped " 792 COL".....

Lowell, 2 miles northwest of, near quarter corner at south side of sec. 8, T. 3 N., R. $16 \mathrm{E}$, east end of northeast abutment of iron bridge over Beaver

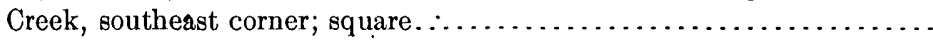

Old Fort, 3.2 miles east of, near quarter corner at south side of, sec. 1. T. $3 \mathrm{~N}$., R. 15 E., east abutment of bridge over Beaver Creek, at northwest corner of bridge seat; bronze tablet stamped "681. COL".

Old Fort, sec. 4, T. 3 N., R. 15 E., east abutment of railroad bridge over Sandusky River, at southwest corner of bridge seat; aluminum tablet stamped "674 COL"

zIEGLERS CORNERS, ALONG HIGHWAY, VIA TIFFIN AND FORT SENECA, TO OLD FORT.

Keller's mill, on southwest stone abutment of bridge over Sandusky River;

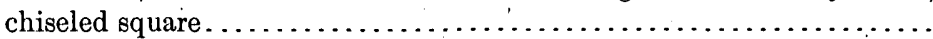

Tiffin, 5.5 miles south of, 100 feet south of crossroads, at Bare schoolhouse, in west wall of stone culvert over drain; bronze tablet stamped " 803 COLUMBUS 1903".

Tiffin, at southwest corner of west face of court-house, in sill of window; aluminum tablet stamped "757 COLUMBUS 1903" (recovered by U. S. C. $\&$ G. S.) . . . . . . . . . . . . . . . . . . . . . . . . . . . .

Fort Seneca, NW. $\frac{1}{4}$ sec. 19, T. 3. N., R. 15 E., west of post-office, in north face of foundation at northeast corner of.schoolhouse; bronze tablet

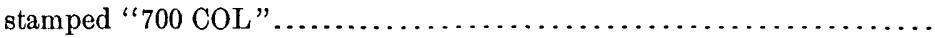

Old Fort, New York, Chicago and St. Louis Railroad crossing; top of north rail

\section{ARLINGTON, BLUFFTON, AND UPPER SANDUSKY QUADRANGLES.}

ALLEN, HANCOCK, HARDIN, PUTNAM, AND WYANDOT COUNTIES.

The leveling in these quadrangles was done in 1904 by H. W. Peabody. BLUFFTON QUADRANGLE.

ERIE BENCH MARK EAST OF LIMA, NORTHEAST TO LAFAYETTE: THENCE EAST ALONG PITTSBURG, FORT WAYNE AND CHICAGO RAILWAY, TO POINT 4 MILES EAST OF ADA.

Lafayette, 1.75 miles west of, at northwest corner of north coping of culvert 151 ; chiseled square (railroad bench mark) . . . . . . . . . . . . . .

Lafayette, 0.25 mile west of, on bridge 148, at northwest corner of east bridge seat; chisel mark (railroad bench mark) .................

Feet.

925.42 
Lafayette, in south face under corner stone by entrance recess to town hall; aluminum tablet stamped " 927 ADJ 1904".

Feet.

Lafayette, 2.7 miles east of, southeast corner of south coping of bridge 135; chisel mark (railroad bench mark).

Lafayette, 2.75 miles east of, in next to top coping stone at northeast corner of bridge 135; aluminum tablet stamped " 950 ADJ 1904 "............

Ada, at northeast corner of Union school building, in east face of water table, 5.5 feet above ground; aluminum tablet stamped "964 ADJ 1904".

951.84

950. 116

963. 860

LAFAYETTE, NORTH ALONG HIGHWA, VIA BEAVERDAM, TO BLUfFTON.

Beaverdam, sec. 32 , T. 2 S., R. 8 E., in northeast corner of town hall; aluminum tablet stamped " 868 ADJ 1904" :....................

Bluffton, sec. 1, T. 2 S., R. 8 E., in west face of stone at northwest corner of town hall; aluminum tablet stamped " $840 \mathrm{ADJ} 1904$ "............

868.067

839.971

BLUFETON, NORTHWEST ALONG HIGHWAY, TO PANDORA; THENCE EAST TO MOUNT CORY.

Pandora, sec. 20, T. 1 S., R. 8 E., at southeast corner of Methodist Church; aluminum tablet stamped "780 ADJ 1904"....................

Pandora, 4.75 miles east of, at southwest corner of sec. 18, T: 1 S., R. 9 E., 4 miles west of Mount Cory, at southwest corner of United Brethren Church; aluminum tablet stamped "803 ADJ $1904 " . . . . . . . . . . . .$.

Mount Cory, sec. 21, T. 1 S., R. 9 E., on water table at southeast corner of Evangelical Church; aluminum tablet stamped "821 ADJ 1904 ".......

ADA, NORTH ALONG HIGHWAY, TO MOUNT CORY.

Orange Township, northeast corner of sec. 21, T. 2 S., R. 9 E., in north face at northeast corner of schoolhouse; aluminum tablet stamped

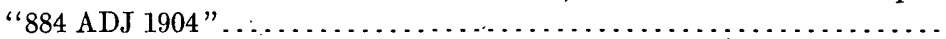

820.903

JENERA, WEST ALONG NORTHERN OHIO RAILWAY, TOWARD BLUFFTON.

Cordelia, at road crossing 100 feet south of railroad, on northeast corner of north abutment of iron bridge; chisel mark....................

MOUNT CORY, NORTHEAST ALONG HIGWAY, TO FINDLAY.

Rawson, sec 13, T. 1 S., R. 9 E., about 50 feet east of northeast end of station platform, in northwest face of bay window of L. M. Osborn's block; aluminum tablet stamped "819 ADJ 1904" . :

818. 496

Rawson, 1.75 miles northeast of, sec. 7, T. 1 S., R. 10 E., 600 feet southwest of road crossing, at southwest corner of arched sandstone culvert, in next to top coping stone; aluminum tablęt stamped "804 ADJ 1904"..

804. 234

\section{ARLINGTON QUADRANGLE.}

POINT 4 MILES EAST OF ADA, EAST ALONG PITTSBURG, FORT WAYNE AND CHICAGO RAILWAY, TO FOREST.

Ada, 4.5 miles east of, at southeast corner of west abutment of culvert 116; chisel mark (railroad bench mark) $\ldots \ldots \ldots \ldots \ldots \ldots \ldots \ldots \ldots \ldots \ldots$.

Ada, 5 miles east of, at railroad crossing, in top stone at northwest corner of east abutment of culvert 114; chisel mark (railroad bench mark).....

North Washington, sec. 15, T. 3 S., R. 10 E., in east face at northeast corner of Presbyterian Church; aluminum tablet stamped "949 ADJ 1903"....

Dunkirk, sec. 18, T. 3 S., R. 11 E., in west face at northwest corner of station; aluminum tablet stamped " 952 ADJ 1903"

948. 240

Forest, 3 miles west of, sec. 10, T. 3 S., R. 11 E., at undergrade road crossing, in northwest corner of west abutment; aluminum tablet stamped "924 ADJ 1903". 
Forest, 2 miles west of, on northwest corner of east back wall of bridge 96 Feet. over Blanchard River; chisel mark (railroad bench mark)............

Forest, sec. 8, T. 3 S., R. 12 E., in north face at northeast corner of city building; aluminum tablet stamped " 934 ADJ 1903 ' '...............

DUNKIRK, ALONG NORTH OIIO CENTRAL RAILWAY, TO ARLINGTON; THENCE WEST ALONG NORTHERN OHIO RAILWAY, TO JENERA.

Williamstown, sec. 36, T. 2 S., R. 10 E., in north face at northeast corner of schoolhouse; aluminum tablet stamped "946 ADJ 1903 "..........

Arlington, sec. 12 , T. 2 S., R. 10 E., in northeast face at northeast corner of Lutheran Church; aluminum tablet stamped "870 ADJ 1903"......

Arlington, 1.25 miles west of, on southeast corner of coping stone at southeast corner of Northern Ohio Railway iron bridge 452 over creek; chisel mark

945.420

869.584

Jenera, sec. 5, T. 2 S., R. 10 E., in east face at northeast corner of M. E. Church; aluminum tablet stamped "850 ADJ 1903 "...............

ARLINGTON, NORTH ALONG HIGHWAY 3 MLLES; THENCE EAST AND SOUTHEAST, YIA HOUCRTOWN AND MOUNT BLANCHARD, TO FOREST.

Arlington, 2.25 miles north of, sec. 25, T. 1 S., R. 10 E., in southwest corner of south abutment of small iron bridge; aluminum tablet stamped "838 ADJ 1903".

837.452

Houcktown, southeast corner of sec. 21, T. 1 S., R. 11 E., in south face at southeast corner of Methodist Church; aluminum tablet stamped "834 ADJ 1903".

Mount Blanchard, 1 mile north of, sec. 26, T. 1 S., R. 11 E., in southeast corner of east abutment of iron bridge over Blanchard River; aluminum tablet stamped " 822 ADJ 1903 ".

821. 708

Mount Blanchard, sec. 12, T. 2 S., R. 11 E., in west face of water table at southwest corner of general store of W. S. \& C. S. Shoemaker; aluminum tablet stamped " 847 ADJ 1903 ".

846.564

Forest, 4 miles north of, at crossroads by Hope Church, in north face at northeast corner of schoolhouse; aluminum tablet stamped "880 ADJ

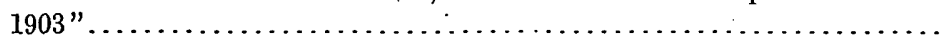

UPPER SANDUSKY QUADRANGLE.

FOREST, EAST ALONG PITTSBURG, FOITT WAYNE AND CHICAGO RAILWAY, TO ROCK RUN.

Forest, 2 miles east of, southwest corner of sec. 3 , T. 3 S., R. 12 E., in next to top coping stone at southeast corner of culvert; aluminum tablet stamped "907 ADJ 1903".

906. 750

Forest, 2 miles east of, at northeast corner of east abutment of railroad bridge 88; chisel mark (railroad bench mark) . . . . . . . . . . . . . . . .

Kirby, east side of sec. 7, T. 3 S., R. 12 E., in east face at southeast corner of D. E. Maxwell's elevator; aluminum tablet stamped "879 ADJ 1903".

Upper Sandusky, 6 miles west of, at northeast corner of coping of railroad

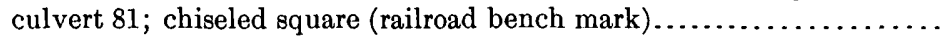

Upper Sandusky, 3.5 miles west of, south side of sec. 34, T. 2 S., R. 13 E., at northeast corner of east abutment of railroad bridge 76 , in stone 2 feet above bridge seat; aluminum tablet stamped " 836 ADJ 1903".

878. 648

865.36

Upper Sandusky, 10 feet east of Hocking Valley Railway and 50 feet south of Pennsylvania line, in stone post; bronze triangulation tablet stamped

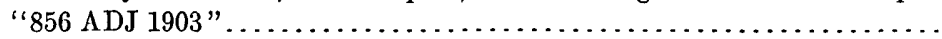

Upper Sandusky, sec. 32, T. 2 S., R. 14 E., at right side of vestibule to main entrance at west side of Wyandot County court-house; aluminum

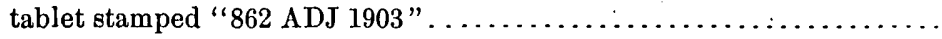


UPPER SANDUSKY, NORTHWEST ALONG HOCKING VALLEY RAILWAY, TO CAREY; THENCE SOUTHWEST ALONG HIG FOUR RAILWAY, TO FOREST.

Upper Sandusky, 3.5 miles northwest of, 50 feet west of Hocking Valley Railway, at northeast corner of east abutment of railroad bridge; chisel mark.

Lovell, south side of sec. 2, T. 2 S., R. 13 E., in south face at southwest corner of M. E. Church; aluminum tablet stamped "816 ADJ 1903"... Feet.

Crawford, southeast corner of sec. 27, T. 1. S., R. 13 E., 450 feet east of railroad crossing, at southeast corner of railroad bridge, in next to top coping stone; aluminum tablet stamped "809 ADJ 1903".

807.993

Carey; south side of sec. 16, T. 1 S., R. 13 E., in west face at northwest corner of M. E. Church, on Main street; aluminum tablet stamped " 825 ADJ 1903"

Carey, 4 miles southwest of, center of sec. 1, T. 2 S., R. 12 E., 0.5 mile southwest of railroad crossing, in next to top stone at southeast corner of culvert; aluminum tablet stamped " 856 ADJ 1903 ".

855. 188

Wharton, north line of sec. 22 , T. 2 S., R. 12 E., in west face at northwest corner of Howard's block, 160 feet back of Big Four Railway station; aluminum tablet stamped " 883 ADJ $1903 " . . \ldots \ldots \ldots \ldots \ldots \ldots \ldots$.

AT M'CUTCHENVILLE.

McCutchenville, in north face of water table of school building; bronze

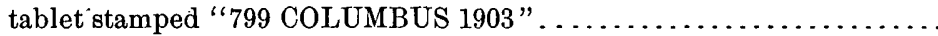

800. 220

CARDINGTON, DELA WARE, DUBLIN, MARYSVILLE, RICHW00D, AND WESTERVILLE QUADRANGLES.

DELAWARE, FRANKLIN, MADISON, MARION, MORROW, AND UNION COUNTIES.

The leveling was done in Dublin, Marysville, and Westerville quadrangles in 1901 and 1902 by C. H. Birdseye; in Cardington, Delaware, and Richwood quadrangles in 1901 by Carleton McRae.

DUBLIN QUADRANGLE.

COLUMBUS, NORTHWEST TO DUBLIN; THENCE EAST TO WORTHINGTON; THENCE SOUTH TO COLUMBUS (DOUBLE CIRCUIT).

Dublin, 5.5 miles south of, west end of south approach wall on east side of Fishinger Bridge over Scioto River; chiseled square.

Feet.

Dublin, at wcst end of steel bridge over Scioto River, in south stone wall; bronze tablet stamped " $805 \mathrm{COL}$ ".

Worthington, on south side of grammar-school building; in arch of foundation over cellar window; aluminum tablet stamped " $884 \mathrm{C}$ ".

884.353

COLUMBUS, NORTHWEST TO HILLIARD; THENCE NORTH TO DUBLIN.

Hilliard, 2 miles south by 0.2 mile east of, at cross pikes, northwest corner of stone culvert; chiseled cross..............................

Hilliard, high-school building, in south end of lower step; chiseled cross. .

Dublin, 3 miles southwest of, 200 feet south of schoolhouse, on northeast abutment of bridge; chiseled cross. . . . . . . . . . . . . . . . . .

DUBLIN, NORTHWEST ALONG PIKES, TO NEW CALIFORNIA; THENCE NORTHEAST, VIA WATKINS, TO BELLPOINT.

New California, in southwest corner of foundation of Jerome Township high school; aluminum tablet stamped " $993 \mathrm{COL}$ ".....................

Watkins, 1.5 miles north of, in top of southwest abument of covered bridge; bronze tablet stamped " 926 COL" 
BELLPONT, EAST ALONG HIGHWAY'; TO STRATFORD; THENCE SOUTH ALONG HIGHWAY, VIA GREGORY, TO WORTHINGTON.

Bellpoint, in northwest abutment of bridge over Mill Creek, in top stone; bronze tablet stamped " 863 COL"..........................

-Gregory, 0.5 mile east of, in southwest corner of foundation of brick schoolhouse (subdivision 7); aluminum tablet stamped " 949 ".

Feet.

Worthington, 3.2 miles north of, High street and road east, Delaware-

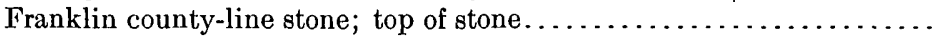

DUBLIN, WEST TO KILEVILLE.

Kileville, 1 mile east of, Union-Franklin county line, 50 feet east of intersection of post-road and free pike; middle of arrow on county-line stone.

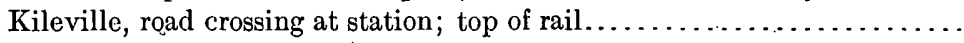

\section{MARYSVILLE QUADRANGLE.}

KILEVILLE, SOUTH TO COVERED BRIDGE OVER DARBY CREEK; THENCE EAST TO HILLIARD.

Hayden, 3.4 miles southwest of, in southeast abutment of covered bridge over Big Darby Creek; aluminum tablet stamped "899 COL".........

\section{WESTERVILLE QUADRANGLE.}

east COlumbus, along piKes, via parks mills, to new albany.

Parks Mills, on southeast abutment of covered bridge over Alum Creek, fourth step from top; bronze tablet stamped " 773 COLUMBUS".........

New Albany, in northeast corner stone of foundation at north side of schoolhouse; aluminum tablet stamped " 1033 COLS"............... 1, 033.845

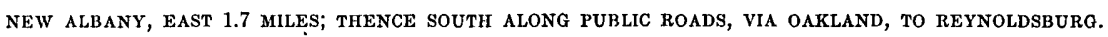

Havens Corners, 1 mile east of, at crossroads, in east wall of foundation of brick schoolhouse; bronze tablet stamped "1022 COL"........... 1, 022.453

PARKS MILLS, NORTH ALONG PUBLIC ROADS, VIA WESTERVILLE AND AFRICA, TO GREGORY.

Westerville, Otterbein University, in top stone of foundation of Association Hall, at northeast corner; aluminum tablet stamped " $859 \mathrm{COL}$ "....... Africa, 0.25 mile west of, east abutment of iron bridge over Alum Creek, in top stone of south wing wall; bronze tablet stamped "831 COLS" $a_{\text {.. }} \quad 833.642$

GREgORY, EAST ALONG PUBLIC ROADS, VIA ROME AND SUNBURY, TO VAN VALLEY; THENCE SOUTH to NEW ALBANY.

Sunbury, in foundation at northeast corner of city hall; aluminum tablet stamped " 970 COLS".....................................

Van Valley, 0.1 mile south of, in top stone of foundation of schoolhouse, at northwest corner; aluminum tablet stamped "1061 COLS"......... 1, 062.045

Center Village, at northeast corner of foundation of schoolhouse (subdivision 6), in top of corner stone; bronze tablet stamped "1068 COLS"....... 1, 068.721

\section{DELAWARE QUADRANGLE.}

Delaware, North along highway on east side of river, to marlboro church.

Delaware, on slab in front of statue at court-house; chiseled mark...... 895.58 Delaware, on northwest steps of city hall; bronze tablet stamped "870 C". $\quad 871.491$ Delaware, 7.75 miles north of, in stone on west side of entrance to Marlboro Church; bronze tablet stamped " $925 \mathrm{C}$ " ................... 925.470

a This bench mark was reset in 1908 by F. O. Cove, county surveyor, at 1.48 feet higher level, making tts elevation 833.642 feet, as here published. 
DELAWARE, NORTḦ TO TROY CHAPEL AND RETURN.

Delaware, 5 miles north of, in stone entrance to Troy Chapel; bronze tablet stamped "942 C"

NELAWARE, WEST ALONG HIGHWAY, TO SCIOTO RIVER; THENCE NORTH, EAST; AND SOUTH TO TROY SCHOOLHOUSE.

Delaware, 5.25 miles west of, in north side of west abutment of bridge on Marysville pike; bronze tablet stamped " $871 \mathrm{C}$ ".................

WARRENSBURG, WEST ON BOKES CREEK, TO NEAR COUNTY LINE.

Lybrand, 1 mile north of, 4 miles north of Ostrander, on culvert 100 yards west of schoolhouse; aluminum tablet stamped " $928 \mathrm{C}$ ".............

MARLBORO CHURCH, WEST TO RADNOR; THENCE NORTH TO PROSPECT; THENCE EAST, VIA WALDO, TO WINDFALL CHURCH.

Radnor, near top step of township hall; bronze tablet stamped " $937 \mathrm{C}$ "... Prospect, in west steps of city hall; aluminum tablet stamped " $908 \mathrm{C}$ "... Waldo, 2.5 miles northeast of, on north wing of east abutment of steel bridge over Olentangy River; bronze tablet stamped " $940 \mathrm{C}$ "...............

RICHWOOD QUADRANGLE.

PROSPECT, NORTHWEST TO WOODLAND AND RETURN.

Woodland, in stone entrance to schoolhouse; bronze tablet stamped "948 C"

CARDINGTON QUADRANGLE.

DELAWARE, EAST ALONG PIKES 4.5 MILES AND RETURN.

Delaware, 4.5 miles east of, on Sunbury pike, north side of east abutment of

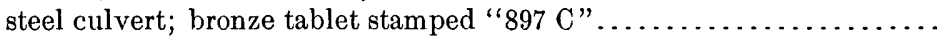

DELAWARE, NORTHEAST, VIA LEONARDSBURG, TO ASHLEY

Leonardsburg, on stone steps of warehouse; bronze tablet stamped " $971 \mathrm{C}$ ".

972.506

\section{EAST AND WEST COLUMBUS QUADRANGLES.}

\section{FAIRFIELD, FRANKLIN, LICKING, AND PICKAWAY COUNTIES.}

The leveling in these quadrangles was done in 1899 by W.. F. Hammond.

\section{EAST COLUMBUS QUADRANGLE.}

DUVALL, NORTH ALONG ROAD, VIA LOCKBOURNE, TO COLUMBUS.

Lockbourne, in top of south pier at west end of Norfolk and Western RailFeet. way bridge over Ohio Canal; aluminum tablet stamped "716 COLUMBUS $1899 "$

Shadeville, 1.5 miles north of, on Spangler Hill, 500 feet east of road, iron post set as triangulation point; stamped " 817 COLUMBUS 1899 "......

Columbus, at northwest corner of court-house, below corner stone; aluminum tablet stamped " 778 COLUMBUS 1899 ".

Columbus, on water table at northwest corner of state capitol; city bench

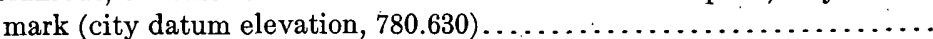


SOUTH COLUMBUS, SOUTHEAST TO BAKER HILL (SINGLE-SPUR LINE).

South Columbus, 2.5 miles southeast of, Baker Hill triangulation station; iron post stamped " 819 COLUMBUS 1899 "

COLUMBUS, EAST TO REYNOLDSBURG; THENCE SOUTH TO MARCY; THENCE WEST TO DUVALL.

Columbus, 3 miles east of, in top of south wing wall of west abutment of main bridge over Alum Creek; aluminum tablet stamped "760 COLUMBUS $1899 "$

Reynoldsburg, in second step of south wing of west abutment of bridge over Blacklick Creek; aluminum tablet stamped " 863 COLUMBUS $1899 "$

Canal Winchester, 0.5 mile south of, north abutment of highway bridge over Little Walnut Creek, in east end of bridge seat; aluminum tablet stamped " 758 COLUMBUS 1899 ".

Lithopolis, 1.5 miles southwest of, on county-line road, in west wing of south abutment of small highway bridge; aluminum tablet stamped "888 COLUMBUS $1899 "$

Duvall, 2.5 miles east of, in west end of north abutment of bridge over Little Walnut Creek; aluminum tablet stamped "711 COLUMBUS 1899".

WEST COLUMBUS QUADRANGLE.

COLUMBUS, WEST ALONG NATIONAl PIKE, TO BIG DARBY CREEK; THENCE SOUTH TO GEORGESVILLE; THENCE EAST, VIA GROVE, TO SPANGLER HILL.

Columbus, 3 miles west of, 1 mile northeast of Camp Chase, 400 feet north of Baltimore and Ohio Railroad, in top of west parapet wall of arch culvert, on Sullivan pike; aluminum tablet stamped "788 COLUMBUS 1899"..

West Jefferson, 1.75 miles east of, in first step of north wing of east abutment of bridge over Big Darby Creek; aluminum tablet stamped "869 COLUMBUS $1899 "$.

788. 494

Grove, 4.5 miles west of, on bridge seat at southeast corner of 10 -foot bridge; chisel mark.

Grove, 4.5 miles east of, on southwest end of parapet wall at southwest corner of bridge over Scioto River; chisel mark.

GROVE, NORTHEAST TO COLUMBUS.

Urbancrest, 900 feet southwest of station, 280 feet west of railroad, in limestone post; bronze triangulation tablet stamped " 836 COLUMBUS 1899 " (south base)

Briggsdale, 0.5 mile north of, on land of $H$. C. Detweiler, west of electric road and south of highway, in top of limestone post; bronze triangulation tablet stamped " 762 COLUMBUS 1899 ". (north base)................

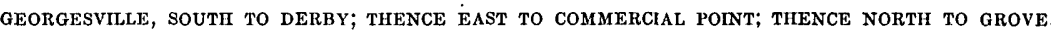

Harrisburg, 3 miles north of, in west end of bridge seat on north abutment of bridge over Big Darby Creek; aluminum tablet stamped "813 COLUMBUS $1899 "$

Harrisburg, 5 miles west of, at common corner of Franklin and Pickaway counties, on east line of Madison County, in stone corner post; aluminum tablet stamped " 933 COLUMBUS 1899 ".

Derby, 0.5 mile southeast of, in bridge seat at west corner of small iron bridge; aluminum tablet stamped " 903 COLUMBUS $1899 " . . . . . . .$.

Commercial Point, in water table at southwest corner of school building; aluminum tablet stamped " 792 COLUMBUS 1899 ". 


\section{CHILLICOTHE, LAURELVILLE, AND WAVERLY QUADRANGLES.}

\section{HOCKING, JACKSON, PICKAWAY, PIKE, ROSS, AND VINTON COUNTIES.}

The leveling in part of Chillicothe quadrangle was done in 1905 by R. P. Thompson; in Laurelville and in part of Chillicothe quadrangles in 1906 by H. W. Peabody; in Waverly and in part of Chillicothe quadrangles in 1906 by R. C. Seitz.

\section{CHILLICOTHE QUADRANGLE.}

CHILLICOTHE, NORTHWARD ALONG HIGHWAY, VIA DELANO, TO KINGSTON.

Chillicothe, on north side of steps to front entrance of court-house, on pedestal of lamp-post; cut marked "Q B-M U S C \& G S Aug 5 1879" ....

Delano, 1,000 feet west of Norfolk and Western Railway station, at east side of National pike and south of Poorhouse lane, in northeast corner of top of concrete bridge of the Scioto Valley Electric Railroad over

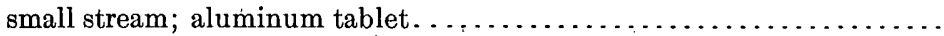

Kingston, in water table at southwest corner of south face of Kingston Hotel, at northeast corner of Main and Pickaway streets; aluminum

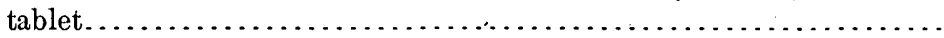

Kingston, 1,000 feet north of station, in top stone of south abutment of highway bridge on National pike; bronze tablet stamped "774 1899 Columbus" (by precise-level line).

Feet.

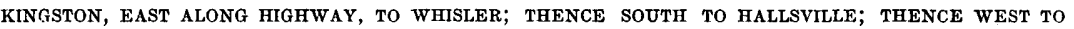
KINNICKINNICK.

Kingston, 2.54 miles east of, 400 feet east of road north, at northwest corner of iron highway bridge, top of round iron post....................

Whisler, in southwest corner of south face of foundation wall of Cumberland Presbyterian Church; aluminum tablet...................

Hallsville, at northeast corner of three corners, in east face of foundation wall, 10 feet north of southeast corner of S: H. Clark's brick store; alumi-

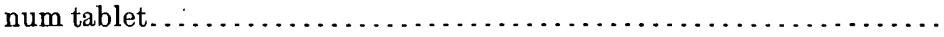

\section{WHISLER, EAST ALONG HIGHWAY, TO ADELPHI.}

Whisler, 3.71 miles east of, 200 feet west of north-south road, on northeast abutment of iron highway bridge over Salt Creek; chiseled square......

CHILLICOTHE, SOUTHEAST ALONG BALTIMORE AND OHIO SOUTHWESTERN RAILROAD, TO VIGO.

Chillicothe, 4 miles southeast of, in top of main pier at southeast corner of overhead crossing bridge; aluminum tablet stamped "623-1906" . . . . . .

Schooley, southeast corner of station building, in east face; aluminum

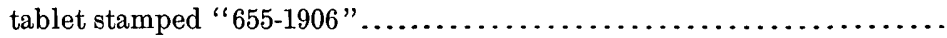

VIGO, NORTHEAST ALONG HIGHWAY, TO COX.

Londonderry (Gillespieville post-office), at northwest corner of crossroads, in south face of brick store; aluminum tablet stamped " $686-1906$ ". . . . . .

Londonderry, about 150 feet north of northeast corner of crossroads, 126 feet northeast of Radcliff's store, in top of sandstone post; aluminum tablet stamped "Prim. Trav. Sta. No. 11"......................

Londonderry, 2.7 miles northeast of, at northeast corner of road fork to north, in south face of foundation at southwest corner of Friends Church; aluminum tablet stamped "626 1906 " 
ADELPH, WEST ALONG HIGHWAY, TO HALLSVILLE.

Adelphi, 2.05 miles southwest of, at southeast corner of three corners at Feet. road to south, 100 feet southeast of Rose's house; spike in root of locust

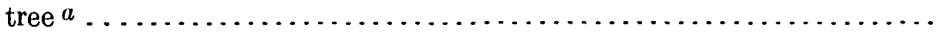

904.67

NEAR RENICK, SOUTH ALONG HIGHWAY, "TO WALLER.

Waller, in lot on west side of road, 200 feet south of $T$ road east; iron post stamped "Prim. Trav. Sta. No. 15629 " . . . . . . . . . . . . . . . . . .

HALLSVILLE, SOUTH ALONG HIGHWY, TO BRTDGE 4 MILES EAST OF CHILLICOTHE.

Hallsville, 2.9 miles south by 0.8 mile west of, at southwest corner of crossroads, in east face at northeast corner of Pleasant View Church; aluminum tablet stamped "792-1906".

Charlestown, 1 mile north of Tucson, southwest side of town, at road forks, at southeast corner of bridge over Walnut Creek, in bridge seat; aluminum tablet stamped "730-1906"

Mooresville, at southeast corner of iron bridge over Walnut Creek, in bridge seat; aluminum tablet stamped "679-1906".

\section{LAURELVILLE QUADRANGLE.}

COX, NORTH ALONG HIGHWAY, TO ADELPHI.

Cóx, 1.5 miles east of, 0.5 mile east of Pike Run bridge, about 0.2 mile east of road fork to north, at southwest corner of iron bridge over Salt Creek, in bridge seat; aluminum tablet stamped " $631-1906 "$. . . . . . . . . . . . . .

Pikerun, northeast corner of small iron bridge over Pike Run, in top abutment stone; aluminum tablet stamped "668-1906" . . . . . . . . . . . .

Pikerun, 3 miles north of, at northeast corner of Thomas Pritchard's yard, in stone post; aluminum tablet stamped "Prim. Trav. Sta. No. $10791-$ $1906 "$

Feightner, in south face at southwest corner of United Brethren Church; aluminum tablet stamped "1140 1906"

Adelphi, northeast corner of I. O. O. F. and post-office building, on Main street, in water table; aluminum tablet stamped " 838 "

\section{WAVERLY QUADRANGLE.}

WAVERLY, NORTH ALONG HIGHWAY, TO WALLER.

Waverly, in court-house yard, west corner; iron post stamped "Prim. Trav. Sta. No. $16590 "$.

Alma, bridge over Crooked Creek, in north wing of west abutment; aluminum tablet stamped " 620 ".

Waller, 2.90 miles south of, 235 feet north of $\mathrm{T}$ road west, at east end of culvert; aluminum tablet stamped " 813 ".

STOCKDALE, NORTH TO BEAVER; THENCE WEST ALONG DETROIT, TOLEDO AND IRONTON RAILWAY, TO NEAR GLEN JEAN JUNCTION.

Robbins, 0.4 mile south of station, in northeast corner of churchyard at Beaver Chapel; iron post stamped "Prim. Trav. Sta. No. 18656 ".......

Givens, 0.5 mile west of station, on top of stone culvert; aluminum tablet stamped "658" 
OMEGA, SOUTHEAST TO CARS RUN SCHOOL; THENCE SOUTH TO ROBBINS.

Omega, 4.80 miles south of, on east side of road, at Cars Run Methodist Church (colored), on top of corner stone separating property of Andrew Harris and Colwine Cotton; aluminum tablet stamped " 601 ".

Feet.

Robbins, 4.20 miles north of, west side of road, on Cars Run, at southeast corner of foundation of schoolhouse (district 17); aluminum tablet

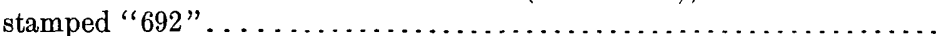

600. 469

691.443

ROBBINS, SOUTHWEST TO GERMANY AND RETURN

Germany, in stone foundation under southwest corner of German Lutheran Church; bronze tablet stamped " 675 I" ......................

NEAR BEAVER, EAST ALONG HIGHWAY, TO GLADE; THENCE NORTH ALONG HIGHWAY, TO VIGO.

Beaver, in front of station; top of rail

664. 6

Beaver, at southwest corner of foundation of public school building, in large sandstone block; aluminum tablet stamped " 691 ".............

Glade, 435 feet south of station, at east side of road in wood lot; iron post stamped "Prim. Trav. Sta. No. 20687 " .......................

Glade, 3.80 miles north of, 200 feet west of Bethel Church, in sandstone outcrop half-way between fences; aluminum tablet stamped " 985 ". . . .

Limerick, in southwest corner of lot of T. J. Beatty, near iron bridge; iron post stamped "Prim. Trav. Sta. No. 19633 "......................

Limerick, 3.6 miles north of, 300 feet south of house west side of road, at east end of culvert; aluminum tablet stamped " 612 ".................

Vigo, 2.7 miles south of, in north face of east pedestal of south arch of overhead B. \& O. Railroad bridge, 1,000 feet east of junction with Cincinnati, Hamilton and Dayton Railway; aluminum tablet stamped "605"

690.724

686. 862

985. 103

632.512

611.477

Vigo, at north side of road, 50 feet east of Baltimore and Ohio Southwestern Railroad, in base stone at southeast corner of A. C. Yoakum's brick house; aluminum tablet stamped " 617 ".....................

\section{LONDON AND SOUTH OHARLESTON QUADRANGLES.}

\section{CLARK AND MADISON COÚNTIES.}

The leveling in these quadrangles was done in 1904 by Frank W. Hughes, and in 1905 by J. A. Ogle.

\section{SOUTH CHARLESTON QUADRANGLE.}

Pitchin, Northeast along highway, via plattsburg, to NEAR SUMmerford; thence west to villa.

Pitchin, 3.8 miles northeast of, at Pleasant Ridge schoolhouse, in northwest corner of foundation, 1.5 feet south of corner; aluminum tablet Feet. not stamped . ................................ 083.893

Harmony, 2.3 miles south of, at Fletcher M. E. Church, in top stone of foundation, 1 foot south of northwest corner; aluminum tablet stamped "1149".

Plattsburg, 3.8 miles west of, at Newlove crossroads, in stone under door of schoolhouse; aluminum tablet stamped " $1109 "$ ". . . . . . . . . . . . . 1., 109. 094

Plattsburg, in foundation on north side 2 feet west of entrance of high school; aluminum tablet stamped "1155" . . . . . . . . . . . . . . . . . 1, 155. 237

Plattsburg, 2.8 miles east of, in stone under door of Wilson schoolhouse;

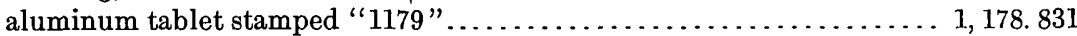


Summerford, 1.2 miles west of, 0.2 mile north of National pike and Columbus, London and Springfield Electric Railroad, 0.4 mile north of Dove Creek school, at southeast corner of parapet of bridge over Deer Creek; aluminum tablet stamped " 1185 ".

Feet.

Brighton, 4 miles north of, 0.5 mile north of Brighton-Tradersville pike, in Lundys lane, 600 feet south of $T$ road, in third stone from top of northeast abutment of bridge; aluminum tablet stamped " 1161 "......... 1, 160.973

Vienna Crossroads, 2 miles north .of, at Pleasant Township school (subdistrict 3), in northwest corner of foundation of W. Shorey's house; aluminum tablet stamped " 1236 ".

Vienna Crossroads, 2 miles north by 2 miles west of, in top stone of foundation of Asbury Church, 2 feet west of southeast corner; aluminum tablet stamped " 1182 ".

New Moorefield, 0.7 foot east of southwest corner of public school building, in top of stone foundation; aluminum tablet stamped " 1054 "........ 1, 054.175

Selma, northeast along highwy near pittsburg, Cincinnati, Chicago and st. louis Rallway, to LONDON.

Selma, in southwest corner of south face of stone foundation of general store at railway station; bronze tablet stamped "1086 COLUMBUS"... 1, 086.077

South Charleston, at southwest side of public school puilding, in top of stone

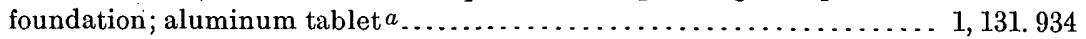

South Charleston, 4 miles northeast of, at crossing of Madison-Clark county line and London pike, in south side of county-line stone; aluminum

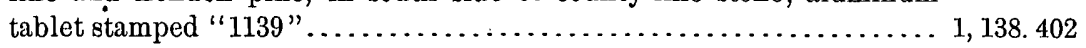

London, 4.6 miles southwest of, 400 feet southwest of house, in top of township-line stone; aluminum tablet stamped " 1122 "................ 1, 121.430

SELMA, SOUTHEAST 1 MILE, TO COUNTY LINE.

Selma, 1 mile southeast of, 150 feet east of fork to northeast, at south margin of road, on top of stone monument; chisel mark "C L". ........... 1, 096.69

LONDON QUADRANGLE.

RANGE, NORTH ALONG HIGHWAY, TO LONDON.

Range; 2.2 miles north of, in brick wall of doorway of Concord schoolhouse; aluminum tablet stamped " $1042 \mathrm{ADJ} 1903$ ".................. 1, 042.466

Newport (near Walnut Run), 3.5 miles south of London, in south end of west wall of schoolhouse; aluminum tablet stamped "1071 ADJ 1903".. 1., 071.496

LONDON, NORTHEAST ALONG HIGHWAY, TO GILLIVAN; THENCE SOUTHEAST TO WEST JEFFERSON.

Lafayette, at southeast corner of brick wall of town hall; aluminum tablet stamped "1013 ADJ 1903"............................... 1, 013. 482

Gillivan, in brick wall at north side of M. E. Church; aluminum tablet

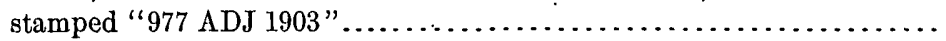

977. 504

COUNTY CORNER EAST OF HIG PLAIN, WEST ALONG HIGHWAY, TO LONDON.

-Big Plain, in top stone of foundation of M. E. Church, 1 foot south of northwest corner; aluminum tablet stamped " 985 ADJ 1903 "...........

Big Plain, 3 miles west of, in parapet stone of bridge over Deer Creek, 3 feet north of northeast corner; aluminum tablet stamped "940 ADJ $1903 "$.

London, 4 miles southeast of, on Big Plain road, 450 feet west of fork of Mount Sterling pike to south, in south end of small stone culvert; aluminum tablet stamped " 1009 ADJ 1903 "....................... 1, 009. 40 
LONDON, NORTHEAST ALONG HUGWAY NEAR PITTSBURG, CINCINNATI, CHICAGO AND ST. LOUIS RAILWAY, TO NEAR WEST JEFFERSON.

Feet.

London, in stone on south side of court-house entrance steps on High street; aluminum tablet stamped " 1054 ADJ 1903 "................... 1, 054.238

London, 3.5 miles northeast of, at Deer Creek bridge on London-West Jefferson pike, in south side of northwest parapet stone; aluminum tablet stamped " 986 ADJ 1903 ".

986. 712

London, 6.4 miles northeast of, at T road north, on top stone of doorstep at left entrance to Glade schoolhouse; aluminum tablet stamped " 977 ADJ $1903 "$.

West Jefferson, 0.2 mile east of city hall, 2 feet east of southeast corner of bridge over Little Darby Creek, in parapet stone; aluminum tablet stamped "898ADJ 1903 "

\section{CONIINENTAL, DEFIANCE, DELPHOS, MCCLURE, NAPOLEON, OTTAWA, AND SWANTON} QUADRANGLES.

DEFIANCE, HENRY, LUCAS, PAULDING, PUTNAM, AND WOOD COUNTIES,

The leveling was done in Defiance, McClure, Napoleon, and Swanton quadrangles in 1907 by W. H. Monahan; in Continental, Delphos, and Ottawa quadrangles the same year by R. C. Seitz. One bench mark was set at Ottawa in 1906 by G. M. Dimmick.

SWANTON QUADRANGLE.

POINT 6 MILES NORTH OF GRAND RAPIDS, NORTHEAST ALONG WABASH RAILROAD AND HIGHWAY, TO BENCH MARK 2 MILES SOUTH OF MONCLOVA. $a$

Whitehouse, in front of station; top of rail. . . . . . . . . . . . . . . . Feet.

Whitehouse, 0.11 mile northeast of, on southwest foundation of Wabash

Railroad pumping station; aluminum tablet stamped " 658 "........

M'CLURE QUADRANGLE.

GRAND RAPIDS, NORTh 6 MILES, TO WABASH RAILROAD.

Grand Rapids, 2.8 miles north of, stone steps of schoolhouse at southwest corner of road crossing; aluminum tablet stamped " $671 " . . . . . . .$.

Grand Rapids, 6.04 miles north of, 300 feet south of railroad, on top of east wing wall of concrete culvert; aluminum tablet stamped " $662 " . . . . . .$.

POINT NEAR M'ClURE, SOUTH TO POINT NEAR WESTHOPE; THENCE EAST TO HANEY. $b$

McClure, 1.51 miles north by 2.88 miles west of, on northeast abutment of bridge over Turkeyfoot Creek; aluminum tablet stamped " 658 "......

McClure, in southwest corner of foundation of schoolhouse; aluminum tablet stamped " 678 ".

McClure, 2.54 miles south of, at frame schoolhouse on northeast corner of crossroads; aluminum tablet stamped " 683 "...................

McClure, 4.34 miles south of, at southeast corner of brick schoolhouse on west side of road; aluminum tablet stamped " 691 ".

$a$ On account of a poor closure this line was continued south to Haskins, making a good closure on the Coast and Geodetic Survey precise line; and a partial readjustment, was therefore made of levels in Toledo quadrangle.

$b$ Closures were made from this line north to Custar and to levels in Bowling Green and Deshler quadrangles. 
Westhope, 3.05 miles south of, at German Lutheran Church on southwest corner of road crossing; aluminum tablet stamped " 702 ".............

Custar, 2.2 miles south by 1 mile east of, on concrete culvert at south side of crossroads; aluminum tablet stamped " 698 ".................

Haney, concrete culvert at west side of crossroads; aluminum tablet

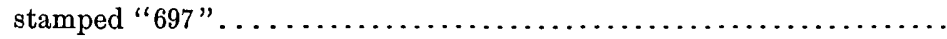

\section{NAPOLEON QUADRANGLE.}

RIDGEVILle CORNERS, SOUTH AND EAST ALONG HighWAY, VIA FLORIDA, TO POINT 5 MILES EAST OF HOLGATE; THENCE NORTH TO POINT 10 MILES EAST OF RIDGEVILLE CORNERS.

Napoleon, 4 miles west of, in northwest corner of foundation of schoolhouse at southeast corner of crossroads; aluminum tablet stamped " 702 "......

Okolona, 1.09 miles north of, 100 feet north of crossroads, at east side of south abutment of bridge; aluminum tablet stamped "702".

Florida, at iron bridge over Maumee River, at top of east end of north stone abutment; aluminum tablet stamped " 671 ".................

Florida, 4.13 miles south of, in foundation of F. Tietje's stable, 175 feet south of road corners and 150 feet west of road; aluminum tablet stamped " $717 "$.

Holgate, 2.02 miles west of, at road intersection in stone abutment of culvert on north side of road; aluminum tablet stamped "711.".

Holgate, 400 feet west of Baltimore and Ohio Railroad station, brick building north of railroad, in south end of east water table; aluminum tablet

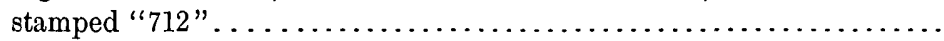

Holgate, 3.96 miles east of, in southwest foundation of German Lutheran Church at northwest corner of crossroads; aluminum tablet stamped " 707 ".

Malinta, 2.85 miles south of, in southwest abutment of concrete bridge over small creek at west side of crossroads; aluminum tablet stamped "694".

Malinta, in concrete front and near southeast corner of Levi Ritter's store;

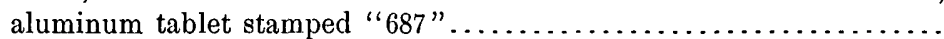

Shunk, 5 miles southeast of Napoleon, in northeast abutment of iron bridge over Turkeyfoot Creek; aluminum tablet stamped " 668 ".............

Shunk, 2.93 miles north of, at brick schoolhouse on southeast corner of road forks; aluminum tablet stamped " $671 " \ldots \ldots \ldots \ldots \ldots \ldots \ldots \ldots$.

\section{DEFIANCE QUADRANGLE.}

DEFIANCE, EAST ALONG HighWAY, TO POINT 5 MILES SOUTH OF FLORIDA.

Defiance, 4.33 miles southeast of, in south west corner of foundation of George Becker's residence; aluminum tablet stamped " 726 " ..............

Defiance, 8.32 miles southeast of, on concrete culvert at west side of road;

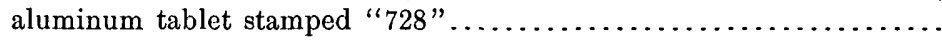

DEFIANCE, WeSt ALONG HIGHWAY 4.9 MILES; THENCE NORTH TO POINT NEAR STRYKeR; THENCE EAST AND SOUTH TO POINT 9.6 MILES NORTH OF DEFIANCE.

Defiance, 1.76 miles west of, on northwest abutment of iron bridge over Tiffin River; aluminum tablet stamped " 681 ".

Defiance, 4.93 miles west of, 150 feet south of road to east, in schoolhouse on east side of road; aluminum tablet stamped " 715 "................

Defiance, 4.8 miles north by 4.9 miles west of, in northwest abutment of bridge over creek; aluminum tablet stamped " 683 "............... 9639-Bull. $411-09-8$ 
Defiance, 4.93 miles west by 7.24 miles north of, on west side of forks of road, in schoolhouse; aluminum tablet stamped " $709 "$. . . . . . . . . . .

Defiance, 4.93 miles west of by 9.34 miles north of, near front entrance of schoolhouse at southeast corner of crossroads; aluminum tablet stamped "712"

Stryker, 2.5 miles south by 0.8 mile west of, at northwest corner of schoolhouse on northeast corner of crossroads; aluminum tablet stamped "716".

Defiance, 12.70 miles north of, 739 feet west of crossroads in northeast abutment of bridge over creek; aluminum tablet stamped " 703 "

\section{OTTAWA QUADRANGLE}

at ottawa.

Ottawa, southeast corner of sec. 21, T. 1 N., R. 7 E., in water table of Hotel Dumont, 2 feet south of side entrance; aluminum tablet stamped "731

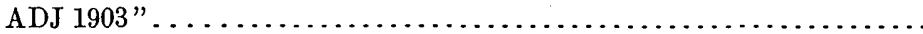

LEIPSIC, WEST ALONG NEW YORK, ChICAGo AND ST. LOUIS RAILROAD, TO CONTINENTAL.

West Leipsic, in front of station; top of rail

765. 0

West Leipsic, 2.55 miles west of, west side of highway crossing, 400 feet north of railroad, in top of concrete catch basin; aluminum tablet stamped "756".

Miller City, 490 feet north of railroad, in top of south guard of concrete culvert over Miller cut-off, 3 feet from west end; aluminum tablet stamped " 733 "

Miller City, in front of station; top of rail . . . . . . . . . . . . . . . . . . .

Kieferville, 300 feet east of station, 75 feet south of railroad and 15 feet west of highway, in concrete catch basin; aluminum tablet stamped " 721 ". .

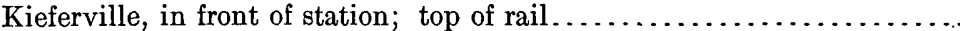

LEIPSIC, NORTH ALONG DETROIT, TOLEDO AND IRONTON RAILWAY, TO HAMLER; THENCE NORTHEAST ALONG BALTIMORE AND OHIO RAILROAD, TO HOLGATE.

Prentiss, in northwest corner of foundation of elevator; aluminum tablet

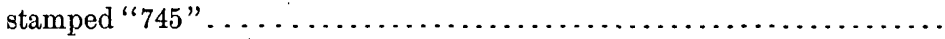

Gallup, in west face of retaining wall under south approach to elevator; aluminum tablet stamped " 735 ".

Hamler, crossing of the Baltimore and Ohio Railroad and the Detroit,

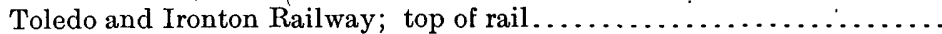

Hamler, 900 feet west of Baltimore and Ohio Railroad station, at west end of south coping of masonry culvert; aluminum tablet stamped " 714 "...

Hamler, 2.42 miles west of, at highway crossing, at west side of concrete culvert about 30 feet south of railroad, in elliptical name plate; crosscut

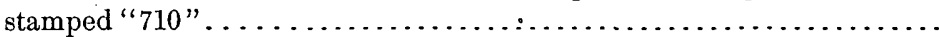

NEAR HOLGATE.

Holgate, 0.75 mile southeast of railroad station, 100 feet north of Baltimore and Ohio Railroad, in southeast corner of forks of road; primary traverse post stamped "Prim. Trav. Sta. No. 10, 1905, 710" 
HOLGATE, SOUTHWEST ALONG TOLEDO, ST. LOUIS AND WESTERN RAILROAD, TO CONTINENTAL.

Holgate, 400 feet west of Baltimore and Ohio Railroad station, at south end of east water table of brick building north of railroad; aluminum tablet

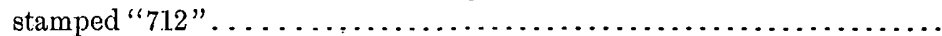

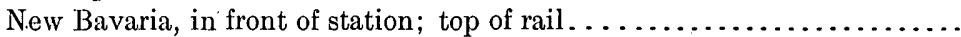

New Bavaria, in stone under east window of brick building 50 feet west of

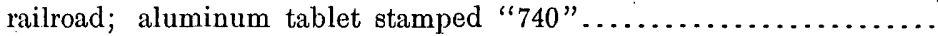

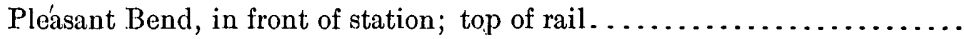

North Creek, in front of station; top of rail. . . . . . . . . . . . . . . . . .

North Creek, 0.35 mile south of, at small iron highway bridge 15 feet east of railroad, in south bridge seat on west abutment; aluminum tablet

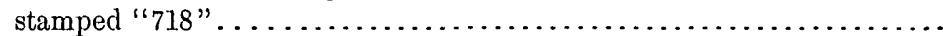

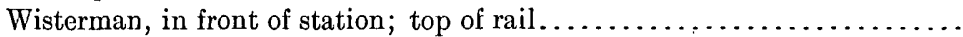

Wisterman, foundation under east end of elevator; aluminum tablet

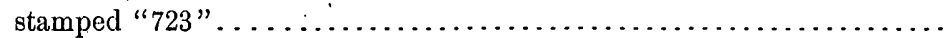

Feet.

712.146

735. 0

739. 534

743. 6

721.0

722.518

CONTINENTAL QUADRANGLE.

CONTINENTAL, WEST ALONG NEW YORK, CHICAGO AND ST, LOUIS RAILROAD, TO OAKWOOD.

Continental, in foundation under New York, Chicago and St. Louis water

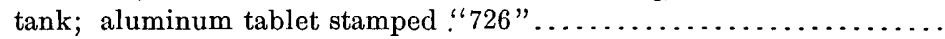

Continental, at crossing of the New York, Chicago and St. Louis and the

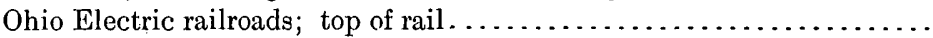

Continental, at crossing of the New York, Chicago and St. Louis and the Toledo, St. Louis and Western railroads; top of rail.................

Hartzburg, at highway crossing in northeast bridge seat of bridge 500 feet south of railroad; aluminum tablet stamped " 719 "................

719. 233

ROSELMS, WEST, NORTH, AND NORTHEAST ALONG HIGHWAYS, TO NEAR DEFIANCE.

Grover Hill, on south abutment of small iron bridge across Main street, 1,090 feet north of railroad, in west wing wall; aluminum tablet stamped

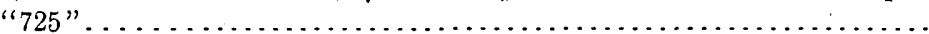

Grover Hill, in front of station; top of rail......................

Grover Hill, 1.02 miles north west of, at northwest corner of crossroads; iron post stamped "Prim. Trav. Sta. No. 4, "727" .

725. 247

728. 6

726. 991

Melrose, 4 miles west of, 990 feet north of New York, Chicago and St. Louis Railroad, 250 feet west of crossroads, in face of south wing wall of east abutment of small iron bridge; aluminum tablet stamped " 708 "......

Paulding, 4 miles east of, on Charloe road, at crossroads, in masonry under west end of small bridge; aluminum tablet stamped " 721 "..........

Junction, 1 mile south by 0.7 mile west of, at top of east wing wall of north butmenta of small iron bridge; aluminum tablet stamped "704".

Junction, 1 mile west by 3 miles north of, in east face of foundation of schoolhouse at northwest corner of crossroads; aluminum tablet stamped " 717 ".

Junction, 3 miles north by 1.5 miles east of, in south coping on west abutment of small iron bridge over canal; aluminum tablet stamped " 717 ". .

71.7. 141

DELPHOS QUADRANGLE.

BENCH MARK SOUTHWEST OF GROVER HILL.

Grover Hill, 1.02 miles west by 1.68 miles south of, at south abutment of small iron bridge, in face of east wing wall; aluminum tablet stamped

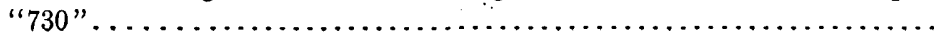




\title{
DESHLER QUADRÁNGLE.
}

\section{HANCOCK, HENRY, PUTNAM, AND WOOD COUNTIES.}

The leveling in Deshler quadrangle was done in 1906 by R. E. Johnson.

\author{
DESHLER QUADRANGLE.
}

OTTAWA, EAST ALONG HIGHWAY, TO BENTON RIDGE; THENCE SOUTHEAST TO BENCH MARK 1.7 MULES NCRTH EAST OF RAWSON. $a$

Ottawa, 3 miles east of, on Ottawa-Benton Ridge pike, 350 feet west of $T$ road north, in southwest corner of a residence yard, in top of marble post; aluminum tablet stamped "Prim. Trav. Sta. No. 4, 739"....... Gilboa, 200 feet north of Cincinnati, Hamilton and Dayton Railway track, in southwest corner of abutment of highway bridge about 600 feet northwest of station; aluminum tablet stamped " $745 " \ldots \ldots \ldots \ldots \ldots \ldots \ldots$.

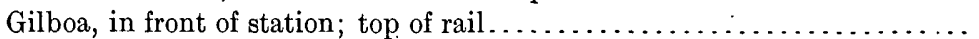
Moffitt, 900 feet south of railroad and highway crossing, 300 feet north of $T$ road west, in southwest corner of stone abutment of wooden bridge over Moffitt ditch; aluminum tablet stamped " 753 " ................

Moffitt, at road crossing at station; top of rail......................

Benton Ridge, in stone foundation of brick public school building, under window 8 feet south of northwest corner; aluminum tablet stamped "778".

Feet.

738. 628

LEIPSIC, EAST ALONG NEW YORK, CHICAGO AND ST. LOUIS RAILROAD, TO M'COMB; THENCE SOUTH TO BENTON RIDGE. $b$

Leipsic, 100 feet northeast of Minnesota street, in stone window sill of Lampe Building, between side entrance door and door to stairway, 18 inches above sidewalk; aluminum tablet stamped " 767 " .............

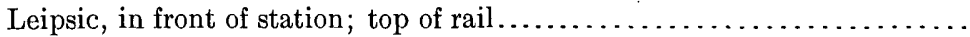

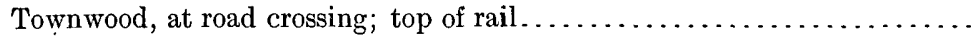

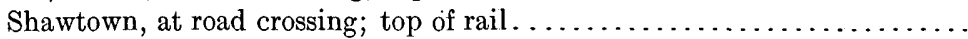

Shawtown, 50 feet southwest of railway crossing, 20 feet south of track and 6 inches from west end of stone culvert; aluminum tablet stamped " 742 ".

McComb, north side of the main east-west street, 20 feet east of north-south street, 60 feet northeast of diagonal turn in street, in stone sill of Smith

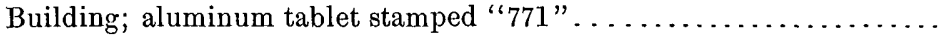

McComb, 3 miles south of, in stone foundation of brick schoolhouse (subdivision 7), 1 foot from southwest corner; aluminum tablet stamped " 809 ".

Benton Ridge, 1 mile northeast of station; cross on east end of stone abutment of wooden culvert at crossroads.

DESHLER, NORTHWEST ALONG BALTIMORE AND OHIO RAILROAD 6 MILES; THENCE EAST AND SOUTH ALONG HIGHWAYS, TO HOYTSVILLE.

Deshler, on Main street, about 300 feet north of Cincinnati, Hamilton and Dayton Railway track, in top of base stone of Gianque block, 4 feet from southeast corner, next to alley; aluminum tablet stamped " 713 "..

Deshler, 6 miles northwest of, 1 mile north of Baltimore and Ohio Railroad tracks, 200 feet south of W. A. Jaqua's residence, in northwest corner of field, at crossroads; iron post stamped "Prim. Trav. Sta. No. 11, 708"... 
Deshler, 3.8 miles northeast of, about 0.75 mile east of Cincinnati, Hamilton and Dayton Railway, about 50 feet southeast of crossroads, at brick schoolhouse; iron post stamped "Prim. Trav. Sta. No. 12, 704" a......

Hoytsville, 2 miles north by 1 mile west of, in southwest corner of southwest stone abutment of small iron bridge over ditch; aluminum tablet

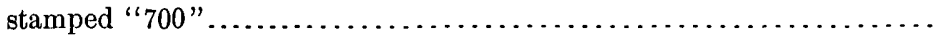

Feet.

703. 600

700. 363

BENCH MARKS AT HOYTSWLLE AND BELMORE (SET FROM U. S. C. \& G. S. PRECISE' LEVELS),

Hoytsville, 1 mile east of, 140 feet east of road crossing, in bridge seat, course of stone at southwest corner of abutment of B. \& O. Railroad

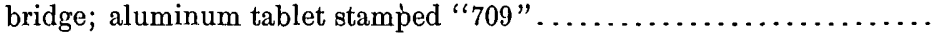

Belmore, in east face of base stone, 6 feet north of southeast corner of town hall, 2.5 feet south of double-door entrance, 1. foot from ground; aluminum tablet stamped " 740 "

\section{COLUMBUS GROVE QUADRANGLE.}

\section{ALLEN AND PUTNAM COUNTIES.}

The leveling in Columbus Grove quadrangle was done in 1905 by G. M. Dimmick.

\section{COLUMBUS GROVE QUADRANGLE.}

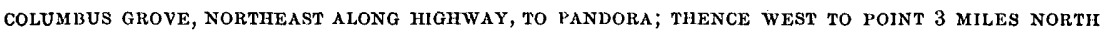
OF COLUMBUS GROVE.

Columbus Grove, at southwest corner of Sycamore and High streets, in water table of Theodore Kenneke Building, 24 feet west of northeast corner; bronze bolt (U. S. C. \& G. S. bench mark " $Q_{1}$ ").............

Feet.

Columbus Grove, northeast corner sec. 33, T. 1. S., R. 7 E., corner of Sycamore and High streets, north face of Kenneke Building, in water table, 24 feet west of northeast corner; aluminum tablet stamped "776 ADJ $1903 "$.

Columbus Grove, 3 miles north of, on second step below bridge seat on south abutment of Cincinnati, Hamilton and Dayton Railway bridge 51; chiseled square (U. S. C. \& G. S. bench mark " $\mathrm{O}_{1}$ ") . . . . . . . . . . .

Columbus Grove, 3 miles north of, between secs. 9 and 10, T. 1 S., R. 7 E., in west end of south abutment of bridge 51; aluminum tablet stamped "748 ADJ 1903".

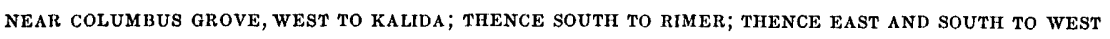
CAIRO.

Columbus Grove, 7.45 miles northwest of, center of sec. 13, T. 1 S., R. 6 E., in brickwork of schoolhouse (district 3 ), at south end of east face; aluminum tablet stamped "740 ADJ 1903 ".

Kalida, center of sec. 5, T. 1 S., R. 6 E., in brickwork of schoolhouse, at west end of south face; aluminum tablet stamped "731 ADJ 1903 ".....

Rimer, 2.3 miles north of, south side of sec. 30 , T. 1 S., R. 6 E., in brickwork of schoolhouse (district 3), at south end of west face; aluminum tablet stamped "749 ADJ 1903".

Rimer, near center of sec. 7, T. 2 S., R. 6 E., in brickwork of schoolhouse (district 9), at north end of east face; aluminum tablet stamped " 760 ADJ 1903". 
Vaughnsville, east side of sec. 10, T. 2 S., R. 6 E., in foundation wall of Christian Church, at south end of west face; aluminum tablet stamped "768 ADJ 1903".

Feet.

Columbus Grove, 3.5 miles south of, west side of sec. 10, T. 2 S., R. 7 E. 70 feet south of highway, in west end of south abutment of railroad culvert over Sycamore Creek; aluminum tablet stamped "791 ADJ 1903".... .

West Cairo, 125 meters west of railroad, on south side of Main street, on northwest corner of foundation of dwelling of Chas. Wallis; brass bolt

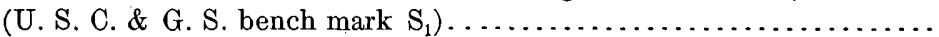

West Cairo, north side of sec. 32, T. 2 S., R. 7 E., in water table of residence of Chas. Wallis, at north end of west face; aluminum tablet stamped

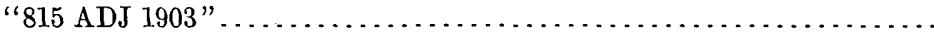

768. 003

790.543

814. 618

814. 594

RIMER, SOUTH ALONG HIGHWAY, TO ALLENTOWN; THENCE EAST TO LIMA.

Rimer, 3.17 miles south of, west side of sec. 29 , T. 2 S., R. 6 E., in water table of schoolhouse (district 3), at south end of west face; aluminum tablet stamped "783 ADJ 1903 "............................

Elida, at southwest corner sec. 8, T. 3 S., R. 6 E., in water table of Methodist Church, at east end of south face; aluminum tablet stamped "797 ADJ

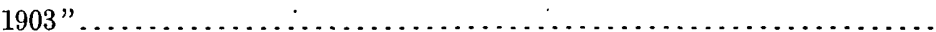

Allentown, 3.48 miles south of, northeast corner of sec. 29, T. 3 S., R: 6 E., in south end of east face of brickwork of schoolhouse; aluminum tablet stamped "823 ADJ 1903 "

lima, Northeast along highWay, to beaverdam; thence West to West cairo.

Lima, 3 miles north of, between secs. 17 and 18, T. 3 S., R. 7 E., in seventh step from top, at northeast corner of viaduct under Cincinnati, Hamilton and Dayton Railway; chiseled square (U. S. C. \& G. S. bench

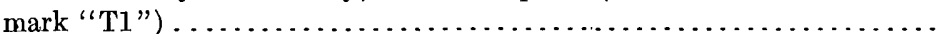

Lima, 3 miles north of, near southeast corner of sec. 7, T. 3 S., R. 7 E., in top of last step of northeast retaining wall of arched stone highway passage under railway track; aluminum tablet stamped "821 ADJ 1903".......

Lima, 6.15 miles northeast of, SW. $\frac{1}{4}$ sec. 11, T. 3 S., R. 7 E., 400 feet north of 5 corners, in top of north end of west retaining wall of stone highway culvert; aluminum tablet stamped "876 ADJ 1903 "

DAYTON, ERA, JEFPERSONVILLE, LIMA, MOUNT STERLING; SIDNEY, SPRINGFIELD, TROY, AND XENIA QUADRANGLE.

\section{ALLEN, AUGLAIZE, ClaRK, FAYETTE, GREENE, MADISON, MIAMI, AND MONTGOMERY COUNTIES.}

The leveling was done in 1903 by H. G. Lowe, C. J. Hoover, W. C. Tupper, and B. J. Green in Springfield quadrangle; by C. W. Marvin and R. G. DeFrees in Lima quadrangle; by R. G. DeFrees in Dayton quadrangle; and by B. J. Green in Mount Sterling, Era, and Jeffersonville quadrangles. Some leveling was done by Messrs. DeFrees, Marvin, and Green in Troy, Sidney, and Xenia quadrangles, respectively. 
LIMA QUADRANGLE.

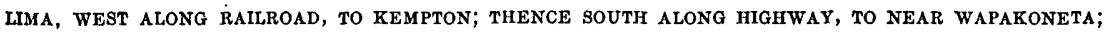
THENCE EAST TO NEAR SANTA FE; THENCE NORTH TO ERIE RAILROAD 4 MILES WEST OF LIMA

Lima, southwest corner of court-house; aluminum tablet stamped "884 COL"

Feet.

Lima, office building of Erie Railroad, 1 foot east of northwest corner;

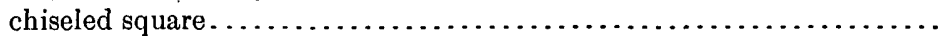

Lima, Western Ohio Electric Railroad crossing over Erie Railroad, on southwest corner of stone pier; at northwest corner chiseled square.....

Kempton, NW. ${ }_{4}^{\frac{1}{4}}$ sec. 6, T. 4 S., R. 6 E., 500 feet north of Erie Railroad crossing, 3 feet north of southwest corner of brick schoolhouse; aluminum

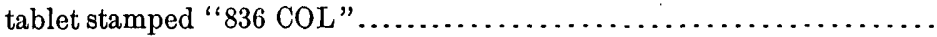

Hume, SE. $\frac{1}{4}$ sec. 30 , T. 4 S., R. 6 W., railroad bridge over Twomile Creek, at southwest corner of back wall of easi abutment; bronze tablet stamped " $845 \mathrm{COL}$ ".

Wapakoneta, SW. $\frac{1}{4}$ sec. 29 , T. 5 S., R. 6 E., iron bridge over Auglaize River, at east end of north abutment, at southwest corner; aluminum tablet stamped " $885 \mathrm{COL}$ "................................

Wapakoneta, 20 feet south of northeast corner of court-house; copper bolt (U. S. C. \& G. S. bench mark " $Z_{1}$ ") ........................

Wapakoneta, 2 miles southwest of, on quarter line north of center sec. 1, T. 6 S., R. 5 E., small iron bridge over Owl Creek, at northwest corner bridge seat on south abutment; square.

884.451

881. 904

877.259

835.769

$8 \dot{4} 5.252$

885.791

898. 519

879.76

Wapakoneta, 3 miles southwest of, near center of Washington Township, sec. 12, T. 6 S., R. 5 E., at T road to east, north side of stone doorsill of schoolhouse (subdistrict 6); aluminum tablet stamped " $908 \mathrm{COL}$ "....

Wapakoneta, 4 miles south of, SW. sec. 20 , T. $6 \mathrm{~S}$., R. 6 E., at small girder bridge of Western Ohio Railway 1,000 feet north of highway, on northwest corner of south abutment; aluminum tablet stamped "973

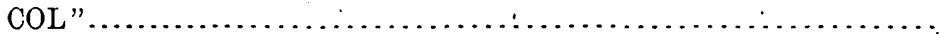

Gutman, 2 miles northeast of, SE. $\frac{1}{4}$ sec. 2 , T. 6 S., R. 7 E., at crossroads, north end of stone doorsill of Lusk schoolhouse; aluminum tablet

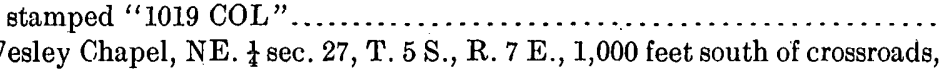
at north end of stone doorsill of M. E. Church; aluminum tablet stamped

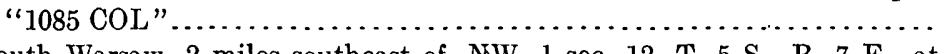

South Warsaw, 2 miles southeast of, NW. $\frac{1}{4}$ sec. 12, T. 5 S., R. 7 E., at southeast corner of crossroads, on stone doorsill at west side of Shamon schoolhouse; aluminum tablet stamped "1005 COL"............. 1, 005. 537

South Warsaw, 0.5 mile north of, SW. $\frac{1}{4}$ sec. 26, T. 4 S., R. 7 E., at iron bridge over Auglaize River, in southwest corner of southeast wing wail; aluminum tablet stamped " $922 \mathrm{COL}$ " ........................

Lima, 4 miles west of, SW. $\frac{1}{4}$ sec. 2 , T. 4 S., R. 7 E., on west abutment of small iron bridge 50 feet east of crossing, at northeast corner of bridge seat; aluminum tablet stamped " $942 \mathrm{COL}$ " $\ldots \ldots \ldots \ldots \ldots \ldots \ldots \ldots$.

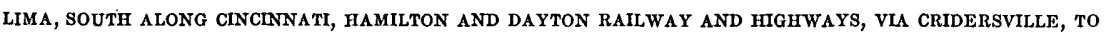
NEAR FRYBURG.

Cridersville, NW. $\frac{1}{4}$ sec. 35, T. 4 S., R. 6 E., Blackburn \& Fisher brick hardware building west of railroad, north side of Main street, in stone doorsill at east end; aluminum tablet stamped " 891 COLUMBUS 1903 ".

Uniopolis, 2 miles west of, NE. $\frac{1}{4}$ sec. 23 , T. 5 S., R. 6 E., at road forks, in stone doorsill at east door of Parlette schoolhouse; aluminum tablet

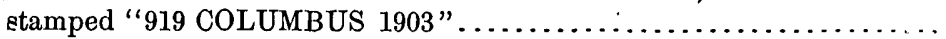


Fryburg, 1.5 miles southeast of, near east line of sec. 23, T. 6 S., R. 6 E., in stone doorsill at north side of Weingarten school; aluminum. tablet stamped "1016 COL"

Feet. $1,016.006$

\section{DAYTON QUADRANGLE.}

DAYTON, NORTHEASt ALONG BIG FOUR RAILWAY, TO OSBORN; THENCE NORTH ALONG HighWAY, TO M'KEN-' DREE CHURCH; THENCE WEST TO NEAR GRAYSON.

Dayton, corner of Main and Fifth streets, in east face of water table at southeast corner of post-office; brass bolt (C. \& G. S. bench mark No. A 3).

Harshman, 2 miles northeast of, 20 feet south of track, in stone wing wall of bridge 153; aluminum tablet stamped " 790 COLUMBUS"...........

Simms, in platform at southwest corner of station; nail................

Osborn, in school building, in top of sill of foundation, 5 feet west of front door; aluminum tablet stamped " 826 COLUMBU்S 1903 ".............

Medway, at northwest corner of Valley turnpike and New Carlisle pike, on east end of east doorsill of hotel building; chiseled square..........

New Carlisle, at northeast corner of city hall, in sill of window at north side; aluminum tablet stamped "907 COLUMBUS 1903 ".

New Carlisle, 4 miles north of, 900 feet east of McKendree Church, at iron bridge over drain, on north side of west abutment; aluminum tablet

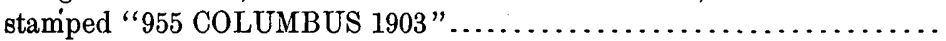

GRAYSON, WEST ALONG HIGHWAY, TO GRANGE HALL; THENCE SOUTH TO DAYTON.

Cowlesville, 2 miles west of, at east side of road 0.25 mile south of crossroads at Grange Hall, near first house south of crossroads, in west face of foundation of large barn; aluminum tablet stamped "902 COLUMBUS 1903 "..

Ginghamsburg, 1.5 miles south by 1.5 miles west of, at Anderson schoolhouse, Butler Township, in face of front doorsill; aluminum tablet stamped "999 COLUMBUS 1903 ".

Spanker, 2 miles southeast of, north of Shiloh Church, in west end of north abutment of Eagle Ford Bridge; aluminum tablet stamped "772 COLUMBUS".

902.064

998. 379

Dayton, on southwest corner of first granite step of soldiers monument; city engineer's bench mark (city elevation, 26.44) ..................

Dayton, Union Street Bridge over Miami River, in top of parapet wall at southeast corner of; aluminum tablet stamped " 755 COLUMBUS 1903"..

754.565

at TIPPECANOE.

Tippecanoe, on Tippecanoe lock, on center of coping of wing wall at northeast side on south end, chiseled square (C. \& G. S. bench mark $\mathrm{T}_{2}$ )......

Tippecanoe, in east side of foundation of school building, north of front door; aluminum tablet stamped "845 COLUMBUS 1903 "............

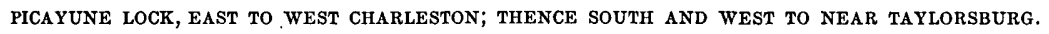

Tippecanoe, 2.5 miles south of, at Picayune lock on Miami and Erie Canal, on coping stone 12 feet south of south king post, 6 inches east of edge of wall; chiseled square (C. \& G. S. bench mark, V 2).................

West Charleston, in west face of sill of foundation of school at northwest corner; aluminum tablet stamped "COLUMBUS 1903 ".

Phoneton, 2.25 miles south of, 0.33 mile south of Wayne Chapel, at west side of road, in south face at southeast corner of foundation of residence of David Orm; aluminum tablet stamped "958 COLUMBUS 1903 "....

Taylorsburg, at south west corner of west abutment of canal bridge, on coping stone; large chiseled cross.................................... 
Tadmor, 2.3 miles south of, Cincinnati, Hamilton and Dayton Railway bridge 8, over Poplar Creek, on west side of north abutment; square

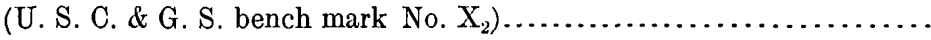

OSBORN, NORTHEAST ALONG BIG FOUR RAILROAD, TO ENON.

Osborn, 1 mile northeast of, Mad River Township, at road crossing, on top stone at northeast corner of abutment of iron bridge over creek; chiseled cross.

\section{SPRINGFIELD QUADRANGLE.}

ENON, NORTHEAST ALONG BIG FOUR RAILROAD, TO SPRINGFIELD.

Enon, Mad River Township, in face of brick wall on north side at northwest corner of Erie Railroad station; bronze tablet stamped "874 COLUMBUS".

Springfield, at north end of west side of fountain opposite east entrance to city hall, in top of stone of base step; copper bolt (city bench mark)....

Springfield, in face of second arched pillar from north end of city hall; aluminum tablet stamped " 979 COLUMBUS"

SPRingField, SOUth aloNG Pike, Via Pitchin, to SELma.

Springfield, east side of Clifton street at Summit avenue, southeast city limits, on north end of stone culvert; chiseled cross.

Springfield, 4.5 miles south of, Springfield Township, on top of abutment wall at northeast corner of high iron-truss bridge over North Fork Little Miami River; chiseled cross............................. $1,028.15$

Pitchin, Greene Township, northwest corner of crossroads, 10 feet south of north end, general store of E. L. Nave, in face of foundation wall at northeast corner; aluminum tablet stamped "1087 COLUMBUS"..... 1, 086.612

Pitchin, 2.75 miles south of, Greene Township, on top of top stone of southeast abutment wall of high iron-truss bridge over Little Miami River; chiseled cross................................... 1, 030.96

SPRINGFIELD, SOUTHWEST ALONG RAILROAD, TO GOES; THENCE SOUTHEAST ALONG HIGHWY, TO CEDARVILLE.

Emery Chapel, 3.9 miles southwest of Springfield, 450 feet south of station, at northeast corner of bridge over Mill Creek, on north abutment; chiseled square.

Hustead, 330 feet south of station, on northwest corner of stone culvert;

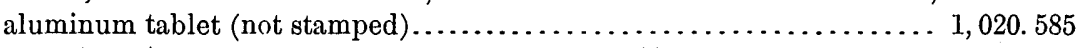

Yellow Springs, 0.6 mile north of, 1.2 miles south of Hennessey station, on southwest corner of stone culvert 158; chiseled square..............

Yellow Springs, 200 feet west of station, on east end of stone step at front entrance to Ridgeway's drug store; chiseled square................

Goes, at front entrance to brick schoolhouse (district 4), in face at north end of doorsill; aluminum tablet stamped " 875 COLUMBUS".

Cedarville, 3.5 miles northwest of, at forks of road, on top of stone culvert; chiseled cross........................................ 1, 003.92

SPRINGTELD, NORTHWEST ALONG TREMONT PIKE, TO EAGLE CTTY; THENCE EAST TO VILLA.

Eagle City, at S. R. Hockman estate, in southeast corner of foundation of white house; aluminum tablet stamped " 927 COLUMBUS"...........

Villa, 400 feet west of north-south road, in southwest corner of foundation of C. R. Marshall's house; aluminum tablet stamped "1079 COLUMBUS" 1, 077. 451 
NORTH HAMPTON, EAST ALONG HIGHWAY, TO EAGLE CITY.

North Hampton, just west of center of town, in north end of west abutment of iron bridge; aluminum tablet stamped "1080 COLUMBUS"....... 1,079. 986

ERA QUADRANGLE

DUBY, SOUTHWEST ALONG BALTMORE AND OHIO SOUTHWESTERN RAILROAD, TO MOUNT STERLING.

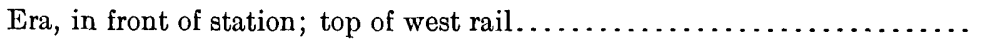

Era, 0.5 mile southwest of station, on south abutment of bridge 14 over Deer Creek, at west end of bridge seat; chiseled square.............

866.55

MOUNT STERLING QUADRANGLE.

MOUNT STERLING, SOUTHWEST ALONG BALTIMORE AND OHIO SOUTHWESTERN RAILROAD, VIA MOUNT STERLING AND BLOOMINGBURG, TO WASHINGTON COURT HOUSE.

Mount Sterling, 2 feett north of main entrance to town hall building, in water table; aluminum tablet stamped " 905 COLUMBUS 1903 ".........

Mount Sterling, at south end of station; top of east rail...............

Cook, east end of south abutment of concrete wall of sewer under public road 100 feet north of station; chiseled square.

905.535

907. 9

911.41

Madison Mills, 300 feet north of station, small iron bridge leading north from station, on top of east end of north abutment; aluminum tablet stamped " 914 COLUMBUS 1903 "

Madison Mills, north end of station; top of east rail ..................

Bloomingburg, on south wall at southeast corner of Bloomingburg mill; aluminum tablet stamped " 980 COLUMBUS 1903 "................

Bloomingburg, north of station, at road crossing; top of east rail.........

Washington Court House, on window seat at south corner of court-house; aluminum tablet stamped " 980 COLUMBUS 1903 "................

WASHINGTON COURT HOUSE, SOUTHEAST ALONG CINCINNATI, HAMILTON AND DAYTON RAILWAY AND HIGHWAY 7 MILES; THENCE NORTHEAST TO NEW HOLLAND; THENCE NORTH TO MOUNT STERLING.

Washington Court House, 6 miles southeast of, on the Robinson road, on south end of west abutment of small iron county bridge; aluminum tablet stamped " 888 COLUMBUS 1903 ".

Wayne-Marion Township line, on east side of road, at foot of hill; top of township-line monument.

New Holland, on Fayette-Pickaway county line, north side of road, at forks to south; top of stone monument.

860. 17

New Holland, on foundation wall of town hall, 3 feet north of main entrance; aluminum tablet stamped " 857 COLUMBUS 1903 "...

856.760

New Holland, south margin of road at southwest corner of cemetery and forks to north; on Pickaway-Fayette county line; top of monument.....

New Holland, 1.35 miles northwest of, on top of east abutment of stone

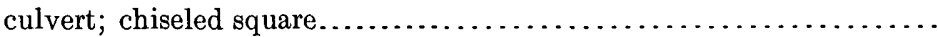

Waterloo (Pancoastburg post-office), 0.9 mile south of, on west margin of Waterloo-New Holland pike, 50 feet south of crossroads, on Fayette-

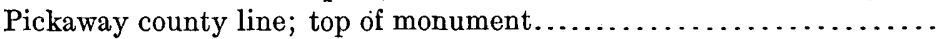

Waterloo, on foundation wall at southeast corner of public-school building; aluminum tablet stamped " 868 COLUMBUS 1903 ".

Waterloo, 1.6 miles north of, on east end of south abutment of small iron bridge; chiseled square.

Yankeetown, 150 feet north of crosspikes, on west end of south abutment of

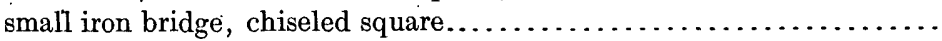

Yankeetown, at west end of north abutment of small iron bridge; aluminum tablet stamped " 842 COLUMBUS 1903 ". 
Mount Sterling, 3.35 miles south of, on top of east abutment of stone culvert;

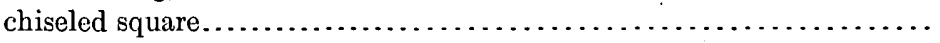

Mount Sterling, 1.75 miles south of, on west margin of pike at FayetteMadison county line; top of stone monument.

MOUNT STERLING, WeSt alONG PUbJic ROADS, VIa RANGE, to SEDALia.

Mount Sterling, 2.95 miles west of, on north end of east abutment of small

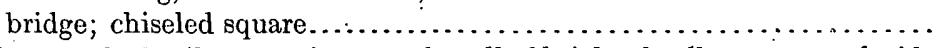

Chenoweth, 2 miles east of, on north wall of brick schoolhouse at south side of pike at fork to south; aluminum tablet stamped " 942 COLUMBUS $1903 "$ ". ................

Range, 1.7 miles east of, on west wall at southwest corner of Bethel Church; aluminum tablet stamped "990 COLUMBUS 1903 ".

897. 17

Sedalia, 0.7 mile east of, just east of cemetery to south, on south end of east abutment of iron bridge; chiseled square..................... 1,043. 85

Sedalia, at southeast corner of Federal and Main streets, on top of stone; aluminum tablet stamped "1071 COLUMBUS 1903 "............... 1,071.748

SEDALIA, SOUTH ALONG HIGHWAY, TO WASHINGTON COURT HOUSE.

Sedalia, 2.25 miles south of, at Madison-Fayette county line, on west margin of pike; top of monument..........................................
Yatesville, 1.7 miles northwest of, on south wall near southeast corner of Green's schoolhouse; aluminum tablet stamped "1034,COLUMBUS

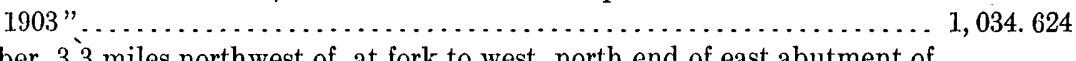

Eber, 3.3 miles northwest of, at fork to west, north end of east abutment of iron bridge over Paint Creek; aluminum tablet stamped "1005 COLUMBUS 1903" 1, 005.940

\section{JEFFERSONVILLE QUADRANGLE:}

SEDALIA, NORTHWEST ALONG HIGHWAY, VIA SOUTH SOLON, TO SELMA.

Sedalia, 3.7 miles west of, on west end of south abutment of covered wooden bridge over Paint Creek; chiseled square.................... 1, 058. 32

Sedalia, 4.95 miles west of, on north end of east abutment of iron bridge; chiseled square...................................... $1,081.90$

South Solon, on north wall near northeast corner of city building; aluminum tablet stamped " 1117 COLUMBUS 1903 "................ 1., 117. 700

South Solon, 3.8 miles west of, on south end of small culvert at crossroads (schoolhouse to north); chiseled square..................... 112. 30

\section{XENIA QUADRANGLE.}

SELMA, SOUTEWEST ALONG PANHANDIE RAILROAD, TO CEDARVILLE.

Cedarville, at southwest corner of United Presbyterian Church, in south face of foundation wall, 2 feet above ground; aluminum tablet stamped "1055 COLUMBUS"

TROY QUADRANGLE.

BENCH MARK SET FROM LEVELS ON DAYTON QUADRANGLE.

Grayson, 0.5 mile north of station, 800 feet south of road fork west to Troy, at fork of road to east, in face of front doorsill of Walnut Grove schoolhouse; aluminum tablet stamped "838 COLUMBUS"

\section{SIDNEY QUADRA NGLLE.}

- BENCH MARK SET FROM LEVELS ON Lima QUADRANGLE.

Geyer, 2 miles southeast of, NW. $\frac{1}{4}$ sec. 27 , T. 6 S., R. 7 E., at southwest corner of Castle schoolhouse; aluminum tablet stamped "1015 COL"... 1., 015. 633 
BROOKVILLE, COVINGTON, GREENVILLE, LORAMIE, ST. HENRY, WEST MANCHESTER, AND WINCHESTER [IND.-0HI0] QUADRANGLES.

AUGLAIZE, DARKe, MERCER, MiAMI, MONTGOMERY, AND PREbLe COUNTIES.

The leveling was done in 1905 in all these quadrangles by $\mathrm{H}$. W. Peabody, except that one bench mark was located in 1908 in West Manchester quadrangle by $\mathrm{H}$. B. Hoel.

BROOKVILLE QUADRANGLE.

COWLESVILLE, WEST ALONG BIG FOUR RAILROAD, TO PITTSBURG.

Kessler, in south face of water table at southeast corner of schoolhouse; aluminum tablet stamped "926 ADJ 1905 ".

Feet.

925.686

Ludlow, 50 feet northeast of Big Four station, south of Ludlow Creek, 3.5 feet from west edge of pier of Dayton, Covington and Piqua Electric Railroad overhead bridge, in south face; aluminum tablet stamped "893 ADJ $1905 "$. .

Laura, west line of sec. 11, T. 7 N., R. 4 E., in south face of southwest corner of foundation of grain elevator on north side of railroad track and east of Main street; aluminum tablet stamped "971 ADJ 1905".

Pittsburg, northwest cormer sec. 7, T. 7 N., R. 4 E., in top of projecting stone in center of north foundation of elevator; aluminum tablet stamped "1029 ADJ 1905" .................................. 1, 028. 746

VERONA, SOUTHEAST ALONG DAYTON AND UNION RAILROAD, TO BACHMAN; THENCE EAST ALONG HIGHWAY, VIA ENGLEWOOD, TO NEAR VANDALIA.

West Baltimore (Verona post-office), northeast corner sec. 12, T. 7 N., R. 3 É., in north face, 10 feet from northwest corner of Landis Tobacco warehouse; aluminum tablet stamped "1027 ADJ 1905"........... 1, 026. 781

Arlington, west of center of sec. 22 , T. 6 N., R. 4 E., in south face, at southwest corner of foundation of Dunkard Church; aluminum tablet stamped

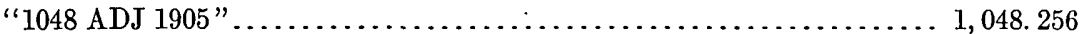

Swanktown, sec. 24 , T. 6 N., R. 4 E., 1 mile northwest of Salem, in bridgeseat stone at northwest corner of small iron bridge over stream east of crossroads; aluminum tablet stamped "988 ADJ 1905"..............

Englewood, quarter corner at south line of sec. 5, T. 5 N., R. 5 E., at northwest corner of the National road and the Dayton, Covington and Piqua Electric line, in stone at south side near southeast corner of Joseph Kingsey's building; aluminum tablet stamped "922 ADJ 1905 "...........

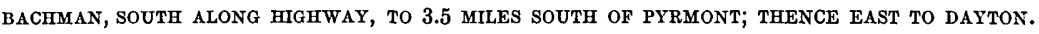

Bachman, 1.5 miles south of, southwest corner sec. 29 , T. 6 N., R. 4 E., in west face of water table at southwest corner of Boomershine brick schoolhouse at northeast corner of crossroads; aluminum tablet stamped "1059 ADJ $1905 "$

Pyrmont, center west side NW. $\frac{1}{4}$ sec. 8 , T. 5 N., R. 4 E., in west face at northwest corner of Calvary Chapel (U. B. Church), 2 feet above ground; aluminum tablet stamped "1053 ADJ 1905"...

Pyrmont, 3.5 miles south of, northeast corner sec. 31 , T. 5 N., R. 4 !E., at southwest corner of crossroads, set in stone casing over ventilator window in north side, 9 feet from northeast corner of May schoolhouse; aluminum

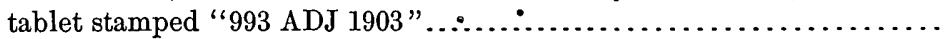

New Lebanon, 0.5 mile west by 1 mile north of, northwest corner NE. $\frac{1}{4}$ sec. 35 , T. 5 N., R. 4 E., at southeast corner of crossroads, 200 feet east of corners, in stone window casing on north side at northwest corner of German Baptist Church; aluminum tablet stamped "947 ADJ 1905"... 
Stillwater Junction, 3.5 miles southwest of, near southwest corner sec. 28, T. 4 N., R. 5 E., 1 mile north of Dayton pike, 10 feet from southeast corner, in south face of bank barn belonging to Henry Moore; aluminum

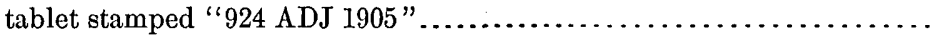

Feet.

Stillwater Junction, 1.5 miles southeast of, near southeast corner sec. 25, T. 4 N., R. 5 E., 3 miles west of Dayton, 1 mile north of Eaton pike, 500 feet west of crossroads by Buckeye schoolhouse, in north face of northeast corner of concrete bridge over stream; aluminum tablet stamped "796

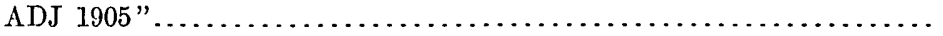

WEST MANCHESTER QUADRANGLE.

PITTSBURG, SOUTH TO VERONA.

Gordon, NE. $\frac{1}{4}$ sec. 35 , T. 8 N., R. 3 E., in.north face at northwest corner of elevator; aluminum tablet stamped "1049 ADJ 1905 "

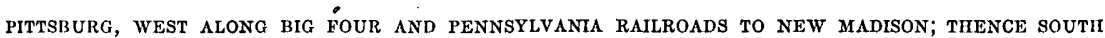
ALONG HIGHWAY, TO POINT 2 MILES NORTH OF GETTYSBURG; THENCE EAST TO BACIMMAN.

Arcanum, 0.25 mile from north line of section 9, T. 8 N., R. 3 E., southwest of crossing of Big Four and Dayton and Union railroads, in north face at northeast corner of foundation of G. R. Keller's grain elevator; aluminum tablet stamped "1053 ADJ 1905".

Beech Grove crossroads, southeast corner sec. 2, T. 10 N., R. 2 E., 0.25 mile north of railroad track, in south face of corner stone at southwest corner of Timothy Reformed Church; aluminum tablet stamped "1096 ADJ 1905". 1, 095. 897

Savona, about center of north side of sec. 9, T. 10 N., R. 2 E., on west side of Cincinnati Northern Railroad and about 900 feet north of Big Four Railroad, at east side of Patty \& Coppock grain elevator, in base of brick chimney; aluminum tablet stamped "1106 ADJ 1905"............. 1., 1.06. 073

New Madison, east of center of sec. 13, T. 10 N., R. 1 E., in west face at southwest corner of U. B. Church; aluminum tablet stamped "1113 ADJ

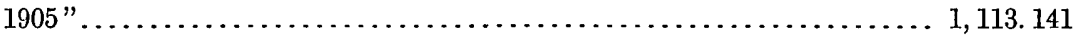

Yankeetown, near northeast corner sec. 35, T. 10 N., R. 1 E., 3 miles south of New Madison, 5.5 miles west of Castine, about 900 feet south of crossroads, in east face of southwest corner of schoolhouse; aluminum tablet stamped "1192 ADJ 1905".

Gettysburg, 2 miles north of, northeast corner sec. 23 , T. 9 N., R. 1 E., 250 feet south of corner of $T$ road south, in water table at east face of northeast corner of McFadden schoolhouse; aluminum tablet stamped "11.98 ADJ $1905 "$.

West Manchester, 3 miles southwest of, near northwest corner sec. 22, T. 9 N., R. 2 E., 600 feet north of Dunkard Church on north-south road, in bridge seat at northeast corner of steel bridge over Price Creek; aluminum tablet stamped " 1103 ADJ 1905".

Euphemia, 2.25 miles west of, east of center of sec. 30, T. 7 N., R. 3 E., in center pier at south end of barn of Mrs. Caroline Weaver on north side of National road; aluminum tablet stamped "1076 ADJ 1905".......... 1, 076.206

Lewisburg, sec. 27 , T. 7 N., R. 3 E., at southeast corner of old Lutheran Church at north edge of town, in northeast face of corner stone; alumi-

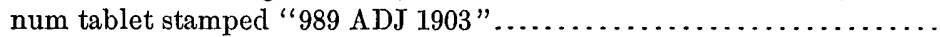

NEW LEXINGTON, WEST TO EATON; THENCE NORTHWEST TO NEWHOPE; THENCE NORTH TO POINT 2 MILES NORTH OF GETTYSBURG.

New Lexington, near southwest corner of sec. 27, T. 6 N., R. 3 E., in east face at southeast corner of New Lexington school building; aluminum tablet stamped "899 ADJ 1905". 
Eaton, 3.9 miles east of, near northeast corner of sec. 31 , T. 6 N., R. 3 E., 1 mile north of Eaton pike, in bridge seat at southeast corner of bridge over Bantas Fork; aluminum tablet stamped "932 ADJ 1905" . ........

Newhope, south of center of sec. 13, T. 8. N., R. 1 E., at northeast corner 931.712 of crossroads near center of village, near center of foundation at south side of United Brethren Church; aluminum tablet stamped " 1153 ADJ $1905 "$

Gettysburg, at north edge of village, south line of $\mathrm{SW} . \frac{1}{4} \mathrm{SW} . \frac{1}{4} \mathrm{sec} .25$, T. 9 N., R. 1 E., in west face at southwest corner of vestibule to schoolhouse; aluminum tablet stamped "1177 ADJ 1905"

NEWHOPE, TO POINT 2.7 MILES SOUTHWEST.

Newhope, 1.5 miles west by 1.2 miles south of, in east abutment of small stone bridge; aluminum tablet stamped " 1204 "................ 1, 204. 305

\section{GREENVILLE QUADRANGLE.}

SAVONA, NORTHWEST ALONG BIG FOUR RAILROAD, TO CLARK STATION; THENCE NORTH TO NASHVILLE; THENCE EAST TO NEW HARRISON; THENCE SOUTH TO POINT 2 MILES EAST OF ARCANUM.

Clark station (Noggle post-office), near center of west side of sec. 36, T. 11 N., R. 1 E., in north face of northwest corner of Noggle \& Son's elevator; aluminum tablet stamped "1095 ADJ 1905".................. 1, 095. 160

Palestine, near southwest corner of sec. 14, T. 11 N., R. I E., at east side of Christian Church, in base of chimney; aluminum tablet stamped

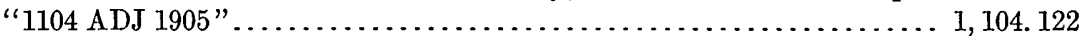

Nashville, northeast corner of sec. 3, T. 11 N., R. 1 E., in foundation at center of north side of Pleasant Grove United Brethren Church; aluminum tablet stamped "1093 ADJ 1905"...................... 1,093.227

Nashville, 2 miles east of, near southwest corner sec. 31, T. 12 N., R. 2 E., 1,000 feet south of crossroads, in west face at northwest corner of Mount Pleasant Lutheran Church; aluminum tablet stamped "1086 ADJ 1905". 1, 086. 282

Greenville, center of sec. 35, T. 12 N., R. 2 E., at south corner of Broadway and Fourth street, in west face at northwest corner of Darke County court-house; aluminum tablet stamped "1050 ADJ 1905"........... 1, 050.091

Greenville, 3 miles east of, near northwest corner of sec. 32, T. $10 \mathrm{~N}$., R. 3 E., 3.5 miles west of New Harrison, at southeast corner of T road south, in west face at northwest corner of Zion Church; aluminum tablet

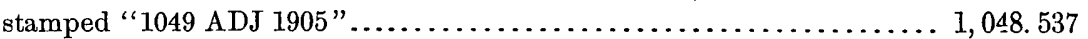

New Harrison, near southwest corner sec. 26, T. 10 N., R. 3 E., at northeast corner of Pennsylvania Railroad bridge over Greenville Creek, in bridge seat; aluminum tablet stamped " 987 ADJ $1905 " . . . . . \ldots \ldots . . . . . .$.

Landis, 0.8 mile southwest of, near center of north line sec. 23, T. 9 N., R. 3 E., at southwest corner of crossroads, in north face at northeast corner of Oakland schoolhouse (subdistrict 8 ); aluminum tablet stamped "1029 ADJ 1905"....................................... 1,029. 066

Arcanum, 3 miles northeast of, at center near south side sec. 35 , T. 9 N., R. 3 E., 800 feet north of crossroads, in bridge seat at southwest corner of small iron bridge over Painters Creek; aluminum tablet stamped "1028 ADJ 1905".................................... 1,027.635

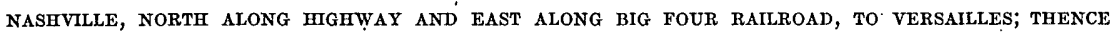
SOUTH ALONG HIGHWAY, TO NEW HARRISON.

Woodington, 3 miles west of, near southeast corner sec. 35, T. 13 N., R. 1 E., 3.5 miles east by 1.5 miles south of Union City, Ind., on north side of road near $T$ road to south, in large stone doorsill to schoolhouse; aluminum tablet stamped "1068 ADJ 1905" 
Elroy station, near northeast corner sec. 25, T. 13 N., R. 1 E., at south side of public road, 300 feet north of track, in north face at northeast corner of schoolhouse (district 12); aluminum tablet stamped "1031 ADJ 1905". 1, 031.233

Ansonia, near center of sec. 22 , T. 13 N., R: 2 E., in south face of water table at southwest corner of M. E. Church; aluminum tablet stamped "1006 ADJ 1905"...................................... 1,005.985

Dawn, south of center of sec. 20, T. 11 N., R. 3 E., 3 miles east of Ansonia, 4.5 miles west of Versailles, in west face at northwest corner of public building; aluminum tablet stamped "1021 ADJ 1905" ........... 1, 022. 332

Versailles, 2.5 miles west of, SE. $\frac{1}{4}$ NW. half way between two road crossings, in west face of small stone culvert 262; aluminum tablet stamped " 1002 ADJ 1905 "

Versailles, 2.75 miles southwest of, near center sec. 36 , T. 11 N., R. 3 E., on north-south road, in bridge seat at southwest corner of bridge over Stillwater River; aluminum tablet stamped "964 ADJ 1905" .........

Oakland, southwest corner sec. 12, T. 10 N., R. 3 E., 2.75 miles north of Gettysburg, in south face at southwest corner of Dunkard Church; aluminum tablet stamped "1014 ADJ 1905"

\section{COVINGTON QUADRANGLE.}

AT VERSAILLES.

Versailles, extreme east line of sec. 24, T. 11 N., R. 3 E., at west edge of town, at southwest corner of Big Four Railroad bridge over Indian Creek, in back wall; aluminum tablet stamped “ 969 ADJ 1905 ”...........

WINCHESTER QUADRANGLE.

BENCH MARKS NEAR EAST BORDER OF QUADRANGLE.

Coletown, 2.5 miles west of, near southwest corner sec. 15, T. 12 N., R. 1 E., at northeast corner of $T$ road to north, 300 feet west of $T$ road to south, in south face of southwest corner of brick schoolhouse; aluminum tablet stamped "1077 ADJ 1905".............................. 1, 076. 650

Elroy, 2.5 miles northwest of, near northeast corner sec. 22 , T. 13 N., R. ' 1 E., 1.5 miles north by 3 miles east of Union City, Ind., in stone of doorsill to Thomas schoolhouse; aluminum tablet stamped "1050 ADJ 1905". 1, 050. 246

\section{ST. HENRY QUADRANGLE.}

THOMAS SCHOOLHOUSE, NORTH AND EAST ALONG HIGHWAY, VIA NORTH STAR, TO YORKSHIRE; THENCE SOUTH TO VERSAILLES.

Rossburg, 6 miles west of, northwest corner sec. 34, T. 14 N., R. 1 E., in north face at northwest corner of brick schoolhouse (district 2); aluminum tablet stamped " 1022 ADJ 1905 "..................... 1, 022, 151

Rose Hill, 1.5 miles northwest of, south of center. of sec. 10, T. 14 N., R. $1 \mathrm{E}$., at diagonal road to southeast, at south end of small stone culvert over large ditch; aluminum tablet stamped "1078 ADJ 1905"....... 1,077.638

New Weston, 1.5 miles southwest of, near center of south line of sec. 9, T. 14 N., R. 2 E., in west face of northwest corner of east abutment of bridge over Wabash River; aluminum tablet stamped "1022 ADJ 1905". 1,021. 291

North Star, 2.5 miles west of, near southeast corner sec. 11, T. 14 N., R. 2 E., in bridge seat at northeast corner of bridge over Wabash River; aluminum tablet stamped " 986 ADJ 1905 " ....................

North Star, southwest corner sec. 9, T. 12 N., R. 3 E., about 130 feet north 985.970 ot crossroads and on east side of road, in west face at southwest corner ot Wabash Township-house; aluminum tablet stamped "1007 ADJ

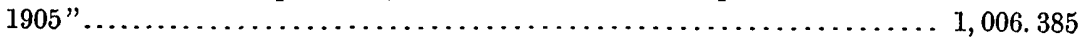


Yorkshire, 3 miles south of, center of north line of sec. 36, T. 12 N., R. 3 E., 1 mile west by 3.5 miles north of Versailles, in bridge seat at southwest corner of bridge over Swamp Creek; aluminum tablet stamped "991 ADJ 1905"

Feet.

990.972

ROSE HiLL, NORTH ALONG HIGHWAY, TO VICTORIA; THENCE NORTHEAST ALONG LAKE AND WESTERN RAILROAD, TO NEAR COLDWATER; THENCE EAST TO AND SOUTHEAST ALONG CINCINNATI, HAMILTON AND DAYTON RAILWAY, TO CHICKASAW.

Fort Recovery, 3 miles south by 1.5 miles east of, near northeast corner sec. 34 , T. 15 N., R. 1 E., at T road north, in water table in north face at northwest corner of Goulder schoolhouse; aluminum tablet stamped "1047 ADJ 1905".

Victoria, near center sec. 15, T. 7 S., R. 1 E., in west face at northwest corner of belfry tower over entrance to St. Joseph Catholic Church; aluminum tablet stamped " 987 ADJ 1905 ".

986.396

Victoria, 2 miles northeast of, southwest corner sec. 1, T. 7 S., R. 1 E., in west face of Oakland schoolhouse; aluminum tablet stamped " 964 ADJ $1905 "$

Coldwater, 2 miles southeast of, near center of south line of sec. 35, T. 6 S., R. $2 \mathrm{E}$., in south face at southwest corner of brick schoolhouse; aluminum

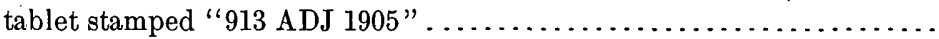

Montezuma, 1.5 miles south of, 1 mile south by 3.75 miles east of Coldwater, near center of north line of sec. 6, T. 7 S., R. 3 E., in bridge seat at southwest corner of bridge over Beaver Creek; aluminum tablet stamped "886 ADJ 1905"

NEW WESTON, NORTH ALONG CINCINNATI NORTHERN RAILROAD, TO NEAR COLDWATER.

New Weston, center of south side of sec. 3, T. 14 N., R. 2 E., at north side of road, about 80 feet west of railroad, in east face at southeast corner of $\mathrm{H}$. Schilling's store and dwelling; aluminum tablet stamped " 1015 ADJ 1905"

St. Henry, 2 miles south of, near northeast corner sec. 33, T. 7 S., R. 2 E., 0.5 mile west of railroad, in north face of Gelhaus schoolhouse, at northwest corner; aluminum tablet stamped " 968 ADJ 1905"

St. Henry, north of center of sec. 21, T. 7 S., R. 2 E., in water table at north face of northeast corner of new schoolhouse; aluminum tablet stamped "974 ADJ 1905".

973.711

St. Henry, 1.75 miles north of, north of center of west line of sec. 9, T. 7 S., R. 2 E., 0:5 mile southeast of Philothea, near south line of Butler Township, in next to top coping stone at north corner of concrete culvert; aluminum tablet stamped "927 ADJ 1905"

\section{LORAMIE QUADRANGLE.}

POINT 2 MILES NORTHWEST OF CHICKASAW, EAST. ALONG HIGHWAY, TO BOTK.INS.

Chickasaw, 2 miles north by 0.75 mile east of, in concrete bridge seat at northwest corner of small iron bridge; aluminum tablet stamped " 899 ADJ 1905"

New Bremen, 3 miles north of, sec. 34, T. 6 S., R. 4 E., on traction line, at southeast corner of crossroads, in west face at northwest corner of brick schoolhouse; aluminum tablet stamped "902 ADJ 1905 "...........

New Knoxville, 2 miles southwest of, north of center of sec. 36, T. 6 S., R. $4 \mathrm{E}$., in north face of northeast corner of Berghorn schoolhouse (subdistrict 2); aluminum tablet stamped "918 ADJ 1905" 
Botkins, 5 miles west of, southeast corner sec. 33, T. 6 S., R. 5 E., at northwest corner of diagonal road to northwest, east side at southeast corner of schoolhouse, in stone under window; aluminum tablet stamped "944 ADJ 1905".

Feet.

943.731

Botkins, 3 miles west of, at southwest corner sec. 36 , T. 6 S., R. 5 E., at northeast corner of $T$ road to north', east face, at southeast corner of schoolhouse, in stone under window; aluminum tablet stamped "965 ADJ 1905"

CHICKASAW, SOUTH ALONG CINCINNATI, HAMILTON AND DAYTON RAILWAY, TO YORKSHIRE.

Chickasaw, southwest corner sec. 11, T. 7 S., R. 3 E., in southeast corner of store and dwelling of H. Gast, in south face in water table; aluminum

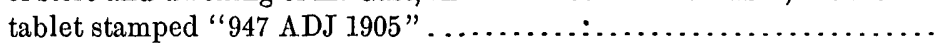

Maria Stein, northwest corner sec. 26, T. 7 S., R. 3 E., in west face, about 10 feet from northwest corner of Myers \& Patty's grain elevator; aluminum tablet stamped "974 ADJ 1905".

946.731

Yorkshire, northeast corner of sec. 13, T. 12 N., R. 3 E., at southwest corner of $T$ road south, in north face at northwest corner of small brick store building; aluminum tablet stamped "988 ADJ 1905" .............

987.208

\section{EATON AND MIAMISBURG QUADRANGLES.}

\section{BUtLer, MONTGOMERY, PREBLe, AND WARREN COUNTIES.}

The leveling was done in Miamisburg quadrangle in 1905 by R. P. Thompson; in Eaton quadrangle in 1908 by H. B. Hoel; and one bench mark was located in Eaton quadrangle in 1905 by $\mathrm{H}$. W. Peabody.

\section{MIAMISBURG QUADRANGLE.}

FRANKLIN, SOUTHWEST ALONG HIGHWAY, TO MIDDLETOWN; THENCE NORTHWEST TO ASTORIA; THENCE NORTHEAST, VIA GERMANTOWN, TO MIAMISBURG.

Franklin, on the northwest corner of Sixth street crossing of Big Four RailFéet. road on southwest of water table; highest point of rounded square exactly in angle (C. \& G. S. bench mark " $\mathrm{I}_{3}$ ").....................

Franklin, near Cincinnati Northern Railroad station at Sixth street, in northwest corner of north face of water table of Eagle mill; aluminum tablet stamped " 685 "

Middletown, No. 216 South Main street, in water table at south side of entrance to Tytus Paper Company's building; aluminum tablet stamped "653".

Astoria, in center of south face of stone doorsill of Pleasant Hill (white brick) Methodist Church; aluminum tablet stamped " 824 ".

Germantown, 5 miles west of, Browns Chapel, at southeast corner of crossroads, in south face of stone doorsill; aluminum tablet stamped " 974 ". .

Germantown, at southwest corner of Market and Walnut streets, in northeast corner of foundation wall of Reform Church; aluminum tablet (reported destroyed 1907).

Miamisburg, at West Linden avenue, northwest abutment of retaining wall of iron highway bridge over Miami River, in center of third top stone; aluminum tablet stamped " $709 "$ "..........................

Miamisburg, at C. H. \& D. Railway station, on south face of retaining wall of west abutment of road bridge over Miami River, 7 feet west of angle in eighth course of masonry below the coping; brass bolt (C. \& G. S. bench

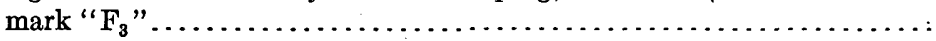
9639-Bull. $411-09-9$ 
MIAMISBURG, NORTH ALONG HIGHWAY, TO NEAR FRYTOWN; THENCE WEST, VIA LIBERTY, TO COUNTY-LINE ROAD; THENCE SOUTH AND EAST TO FARMERSVILLE; THENCE SOUTHEAST TO GERMANTOWN.

Frytown, 0.5 mile south of, north corner of crossroads, in southeast corner of red brick schoolhouse at Lower Miami Church; aluminum tablet stamped " 824 "

Liberty, in south face at southwest corner of water table of St. Paul's Church; aluminum tablet stamped " 840 ".

New Lebanon, 1 mile south of, at T road north, in south face at southeast corner of red brick schoolhouse (district 5); aluminum tablet stamped " $910 "$

Farmersville, 4 miles northwest of, at northwest angle of five forks, in top stone at west end of county-line road culvert; aluminum tablet stamped " 929 "

Farmersville, 3 miles west of, 0.2 mile north of east-west road, west of county-line road, in northeast corner of water table, east face of red brick house of David Wampler; aluminum tablet stamped " 890 "......

Farmersville, in water table, east face of south entrance to public school;

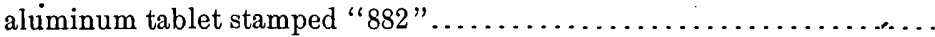

EATON QUADRANGLE.

EATON, SOUTH, VIA CAMDEN, TO SEVENMILE.

Eaton, southwest corner sec. 35, T. 8 N., R. 2 E., at southwest corner of North Barron and East High streets, in west face of water table at northwest corner of public school building; aluminum tablet stamped " 1055 ADJ 1905"

Eaton, 2.6 miles south of, in west side of south abutment stone-arch railroad bridge over east-west road; aluminum tablet stamped " 984 "....

Eaton, 6.1 miles south of, in west end of south abutment of iron railroad bridge over Sevenmile Creek; aluminum tablet stamped " 903 ".

Camden, 70 yards east of railroad station, in north side of west abutment of iron county bridge over Sevenmile Creek; aluminum tablet stamped

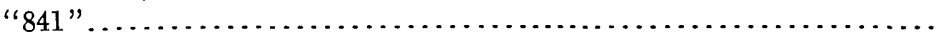

Camden, 3 miles south of, in east side of south abutment of iron railroad bridge over Sevenmile Creek; aluminum tablet stamped " 790 "

Somerville, in front of station; top of rail (marked " 762.0 ")

Somerville, 1.28 miles.south of, in east side of south abutment of wooden railroad trestle over Sevenmile Creek; aluminum tablet stamped " 736 ".

Collinsville, in front of station, top of rail (marked "699.4"). ............

Collinsville, 0.9 mile south of, in east side of north abutment of iron railroad bridge over Sevenmile Creek; aluminum tablet stamped " 691 "........

735. 651

COLLINSVILLE, WEST TO OXFORD; THENCE NORTH, VIA MORNING SUN, TO POINT 5.5 MILES WEST OF EATON.

Collinsville, 2.35 miles west of, south of road, 30 feet from lane leading to residence of J. Harris, on large rock; chiseled square marked "862.01"..

Collinsville, 2.74 miles west of, in northwest corner at north side of foundation of residence of Cornelius Irwin, 1 foot above ground; aluminum tablet stamped " 816 ".

Darrtown, 0.75 mile north by 2.09 miles west of, on rock at $T$ road north;

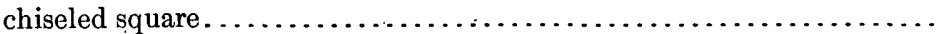

Oxford, 1.82 miles east of, in northwest corner at north side of foundation of residence of $\mathrm{C}$. Hoffman, 1.4 feet above ground; aluminum tablet stamped " 809 ".

Oxford, in water table in southwest corner at west side of foundation to city hall; aluminum tablet stamped " 953 " 
Oxford, 3 miles north of, on large rock at $T$ road east; chiseled square

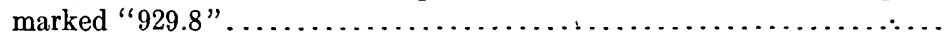

Oxford, 3.6 miles north of, in west side at south end of foundation wall to residence of Charles P. Pfister; aluminum tablet stamped " 991 ".......

Morning Sun, 1 mile south of, in northeast corner at east side of foundation

to brick residence of E. E. Elliott; aluminum tablet stamped " 1025 ".. 1, 024. 686

Morning Sun, on stone walk in front of United Presbyterian Church; chiseled square marked " 999.9 ".

Feet. 929. 56

990. 915

999. 74

Morning Sun, 2.1 miles north of, at crossroads, in northwest corner at west side of foundation to Ramsey schoolhouse (district 2); aluminum tablet stamped " 1038 ".

Morning Sun, 5.15 miles north of, on large rock at crossroads; chiseled square marked " 1086.9 " ............................... 1, 086. 74

Morning Sun, 5.65 miles north of, at east-west crossroads, in east side of north abutment of small concrete bridge; aluminum tablet stamped "1093".

Morning Sun, 9.25 miles north of, in west side of south abutment of wooden bridge over stream; aluminum tablet stamped " 1119 " ............. 1, 118.908

POINT NEAR MORNING SUN, NORTHEAST, VIA CAMDEN AND GRATIS, TO POINT NEAR FARMERSVILLE.

Camden, 2 miles west of, 100 yards west of crossroads and north of road, in southeast corner at east side of foundation to Lowe Church; aluminum tablet stamped " $1011 " . \ldots \ldots \ldots \ldots \ldots \ldots \ldots \ldots \ldots \ldots \ldots \ldots \ldots \ldots \ldots ., 010.763$

Camden, 3.25 miles east of, in south side of east abutment to wooden bridge over Aukerman Creek; aluminum tablet stamped " 914 " ..............

Gratis, at south west corner of Franklin and Main streets, in northeast corner at east side of foundation to general store of $\mathrm{E}$. H. Carr; aluminum tablet stamped "876-1908".

Gratis, 5 miles north by 1.5 miles east of, at $T$ road north, on stone culvert opposite Dunkard Church; chiseled square marked " 803.27 "..........

Farmersville, 4 miles west of, at crossroads, on southwest corner of concrete floor of small iron bridge; chiseled square marked " $875.9 " \ldots \ldots . \ldots$.

803. 02

875.63

\section{BLANOHESTER QUADRANGLE. \\ CLINTON COUNTY.}

The leveling in Blanchester quadrangle was done in 1905 by C. W. Ogle and R. P. Thompson. The Coast and Geodetic Survey precise line in this vicinity could not be recovered.

\section{BLANCHESTER QUADRANGLE.}

CLARKSVILLE, EAST ALONG CINCINNATI AND MUSKINGUM VALLEY RAILROAD, TO CLINTON.

Clarksville, northeast corner of J. E. Linn \& Co.'s store; aluminum tablet stamped " 817 ADJ 1903"................................

Clarksville, 2.5 miles east of, on northeast corner of east abutment of railroad culvert; chiseled square.

Feet.

816. 817

Ogden, 1 mile east of, on southwest corner of west abutment of railroad bridge over Lyttle Creek; chiseled square.

856. 50

Ogden, 2.5 miles east of, on southeast corner of east abutment of railroad bridge; chiseled square:

Wilmington, in stone foundation of east side steps to court-house; aluminum

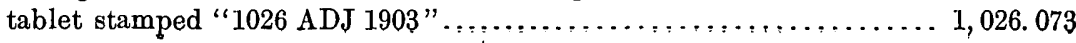


Wilmington, 2.75 miles east of, on north end of east abutment of box culvert; Feet. chiseled square.................................... 045.74

WILMington, NORTheAst aloNg PIKE, To CLINTON.

Wilmington, 4.4 miles northeast of, in stone step of door to brick schoolhouse (Dutch school); aluminum tablet stamped "1046 ADJ 1903".... 1, 046. 026 WILMINGTON, NORTHWEST ALONG HARVEYSBURG PIKE, TO JONAHS RUN CHURCH; THENCE SOUTH TO. CLARKSBURG.

Wilmington, 2.5 miles northwest of court-house, on doorsill of schoolhouse of Union Township; chisel mark......................... 1, 019. 39

Oakland, in southwest corner of foundation wall of schoolhouse; aluminum tablet stamped "1008 ADJ 1903 " . ......................... 1, 008. 207

Harveysburg, 1.5 miles east of, in southeast corner of foundation of Jonahs Run Church (Baptist); aluminum tablet stamped "943 ADJ 1903"..... Clarksville, 3 miles north of, at Vandervorts Corners, in east end of 10 -foot arch culvert under highway; aluminum tablet stamped "951 ADJ 1903".

WILMINGTON, SOUTHEAST ALONG HIGHWAY, TO NEAR NEW ANTIOCH; THENCE SOUTHWEST TO MARTINSVILLE; THENCE NORTHWEST TO CUBA; THENCE NORTH ALONG BALTIMORE AND OHIO SOUTHWESTERN RAILROAD, TO WILMINGTON.

Wilmington, 5.1 miles southeast of, 0.75 mile west of New Antioch, in top of east abutment of north wing of highway bridge; aluminum tablet stamped "1049 ADJ 1903"............................... 1, 049. 232

Martinsville, in stone step at east door of Odd Fellows Hall; aluminum tablet stamped "1086 ADJ 1903 ".

Cuba, 250 feet west of station, in bridge seat at east end of west abutment B. \& O. Railroad crossing of highway; aluminum tablet stamped " 1034 ADJ $1903 "$

Cuba, 2.5 miles northeast of, at road crossing, on east side of $B$. \& O. Railroad track and 8 feet southwest of old wall, on north end of highway culvert; chiseled square............................... 1, 045. 37

MARTINSVILLE, SOUTH ALONG HIGHWAY 7 MILES; THENCE WEST TO BLANCHESTER; THENCE NORTH TO CLARKSVILLE.

Martinsville, 4 miles south of, in northwest corner of Glady brick schoolhouse (subdistrict 4, Clark Township), in stone water table; aluminum tablet stamped " 1023 ADJ 1903 ".......................... 1,023. 064

Westboro, 3.2 miles east of, south end of east abutment of highway bridge;

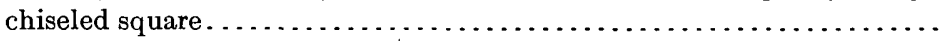

Westboro, 600 feet west of station, B. \& O. Railroad bridge crossing West Fork of East Fork, in top of south concrete wing wall of east abutment; aluminum tablet stamped " 980 ADJ 1903 "....................

Blanchester, on northwest corner of Main and Broadway, in stone at southeast corner of 2 -story brick building belonging to F. N. Carnaham; aluminum tablet stamped " 971 ADJ 1903 ".........................

Blanchester, 4.35 miles north of, in northeast corner of brick schoolhouse; aluminum tablet stamped " 976 ADJ 1903 "....................

980. 427

970.804

976. 383

EAST CINCINNATI, HAMILTON, LEBANON, MASON, AND WEST CINCINNATI QUADRANGLES.

BUTLER, HAMILTON, AND WARREN COUNTIES.

The leveling in East and West Cincinnati quadrangles was done. in 1898 by Ralph Stewart, and in Hamilton, Lebanon, and Mason quadrangles in 1903 by E. O. Garvin. Elevations in Kentucky in East and West Cincinnati quadrangles will be published in a later bulletin. 
WEST CINCINNATI QUADRANGLE.

Winton Place, 400 feet southeast of Big Four Railroad station, west end of Feet. north abutment of plate girder of railroad bridge; highest point in circular

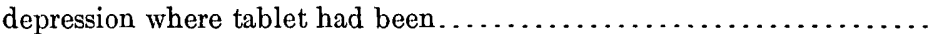

Cheviot, intersection of Walnut street and Harrison pike; aluminum tablet stamped "Cin 915 "

Cleves, foundation of northwest corner of township hall; bronze tablet stamped "Cin 499 "

Miami, large steel bridge across Miami River, top of south end of east abutment; bronze tablet stamped "Cin 522 ".

521.450

Barnesburg, 0.5 mile northwest of, on Bluerock pike, south corner of foundation of St. Paul German Evangelical Church; aluminum tablet stamped "CIN 863"

862.734

EAST CINCINNATI QUADRANGLE.

Miamiville, Pennsylvania Railroad bridge over Little Miami River, east end of north abutment; aluminum tablet stamped "CIN $570 " . . . . .$. .

Mount Carmel, on coping at southeast corner of foundation of schoolhouse; aluminum tablet stamped "CIN 882 "

569. 186

881.375

Ninemile, steel bridge 0.5 mile south of junction of three forks of Ninemile Creek, at west end of north abutment; aluminum tablet stamped "CIN $539 "$...

California, at city waterworks pumping station, on east end of culvert under driveway nearest river; aluminum tablet stamped "CIN $487 " \ldots \ldots \ldots$.

Madisonville, Baltimore and Ohio Southwestern Railroad crossing at Central avenue, east end of south abutment of plate-girder bridge, first step from bottom; aluminum tablet stamped "CIN 588 "................

Silverton, 0.3 mile east of, south side of Montgomery pike, 150 feet west of Madisonville road, on south end of culvert; aluminum tablet stamped "838 CIN" ..............................................

\section{HAMILTON QUADRANGLE.}

HAMILTON, WEST ALONG HIGHWAY, TO ST. CHARLES.

Hamilton, at northeast corner of foundation of court-house, north half west edge of inclosed surface, 15 inches east of east pilaster of basement door and 3 inches north of wall; 2.5-inch square cut in stone, lettered "Datum, City elevation $100^{\prime \prime}$ ' (C. \& G. S. bench mark "Hamilton City")........

Hamilton, west edge of, drawbridge over Miami River, in northwest abutment, in top of third stone from bridge; chiseled square..............

Millville, covered bridge over Indian Creek, at southeast corner, in top stone, 1.9 feet above ground; chiseled square.

Selkirk (Auburn), in northwest corner of top stone, near brick wall of front entrance to brick schoolhouse (No. 7); chiseled square................

St. Charles, 1.8 feet west of south foundation wall of St. Charles (Reily Township) joint district school, 2.9 feet above ground; aluminum tablet

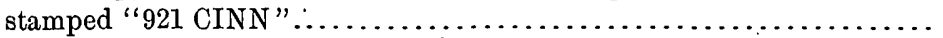

ST. CHARLES, NORTH ALONG HIGHWAY, TO WOODS; THENCE NORTHEAST TO DARRTOWN; THENCE SOUTHEAST TO OVERPECK.

Darrtown, 1.5 miles southwest of, on road northwest to Oxford, northwest end of small wooden bridge, in top stone of foundation; chiseled square.

Darrtown, in north foundation wall of schoolhouse (subdistrict 5), at west door to north entrance; aluminum tablet stamped "742 CINN"....... 
Darrtown, 2.25 miles south of, private road east to east-west section road passing through Sevenmile, on top stone of northeast abutment of red iron bridge; painted square ...................................

Sevenmile, center of north line of St. Clair Township, Sevenmile schoolhouse (special district), in north foundation wall of east entrance, 2 feet above ground; aluminum tablet stamped " 652 CINN".

Sevenmile, in front of station; top of rail (marked " $643.4 ")$................

ST. CHARLES, SOUTHEAST ALONG HIGHWAY, TO BARNESBURG; THENCE NORTHEAST, VIA NEW BURLINGTON, TO FURMANDALE; THENCE EAST TO JONES.

Shandon, in north wall of foundation of schoolhouse (special district 7), 1.9 feet from west wall and 2.4 feet above ground; aluminum tablet stamped "603 CIN"

New Baltimore (Slater), 2.6 miles northwest of, at road forks, in top of second stone from northwest end of abutment of white iron bridge; chiseled square.

603. 232

New Baltimore, 3 feet north of northwest truss of red iron bridge over Miami River, in top stone of northwest abutment, 3 feet above bridge floor; aluminum tablet stamped " $543 \mathrm{CIN}$ ".

New Burlington (Transit), in stone above cellar window in window of vestibule of schoolhouse (district 12), 4.5 feet from west wall, 2.6 feet above ground; bronze tablet stamped " $828 \mathrm{CIN}$ "............

Furmandale, NE. $\frac{1}{4}$ sec. 34, 3 miles south of Hamilton, on Mill Creek Valley Electric Railroad, in south foundation wall of schoolhouse (district 6) 0.4 foot from west wall, 1 foot above ground; aluminum tablet stamped "606 CINN"

Jones (Stockton) 1.5 miles north of, 4.5 miles southeast of Hamilton, on second stone step below bridge seat of Cincinnati, Hamilton and Dayton Railway bridge 11; chiseled square (C. \& G. S. benchmark " $\mathrm{G}_{4}$ ") .........

MASON QUADRANGLE.

CRESTVUE, EAST ALONG HIGHWAY, TO LOVELAND; THENCE NORTH TO NEAR RED LION.

Crescentville, 1 mile south of, iron bridge over Miami and Erie canal, in second stone from top of northwest abutment; chiseled square.........

Brecon, at west door of Bethel M. E. Church, near west end of top stone step; chiseled square.

Loveland, at iron bridge over Little Miami River, near northeast corner of northwest abutment, in coping stone 0.5 foot from and 1.5 feet below bridge floor; bronze tablet stamped " 584 CINN" ................

Loveland, 3.5 miles north of, at northwest corner of bridge 84 , on southeast corner of northwest abutment; chiseled square...................

Foster, 100 feet south of road crossing at station, in northwest abutment of bridge 82 , at northwest corner; chiseled square..................

Camp Hagerman, 1.3 miles south of, 300 feet south of road crossing, in stone of northwest abutment of iron drawbridge; chiseled square...........

NEAR RED LION, WEST ALONG HIGHWAY, TO EXCELLO.

Red Lion, 2 miles south of, at crossroads 50 feet south of stream, in northeast abutment of wooden bridge; chiseled square....................

Blue Ball, in east front foundation wall of schoolhouse (subdistrict 8), 1.5 feet from vestibule wall and 3 feet above ground; aluminum tablet stamped " $734 \mathrm{CINN"}$ "................................

Excello, on lock of Erie and Miami Canal, at north end of west wall of tum-

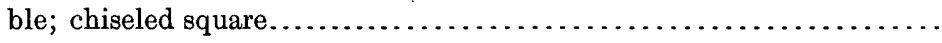


AT TRENTON.

Trenton, north end of town, Madison Township, in south wall of south wing of schoolhouse (district 9), in south doorsill of store in L, 3 feet from ground; aluminum tablet stamped " 673 CINN".................

Feet.

haMilton, EAST ALONG HighWAY, TO HUGHES; THENCE SOUTH TO SHARONVILLE.

Hughes, in south wall of stone foundation at southeast corner of schoolhouse (subdistrict 4), 0.6 foot from east wall and 1.6 feet above ground; aluminum tablet stamped " 769 CINN".

769.096

Westchester, east of town, in water table of south foundation of Union Township schoolhouse (district 3), 3.5 feet west of vestibule wall of main entrance and 3.4 feet above ground; aluminum tabletstamped "701 CINN".

Sharonville, in south foundation wall of Sycamore Township public school (district 2), 0.6 feet west of sill to main entrance under tower, 2.2 feet above ground; aluminum tablet stamped " $591 \mathrm{CINN"............}$

LEBANON QUADRANGLE.

BENCH MARKS AT RED LION AND KINGS MILLS SET FROM LEVEL LINES ON MASON QUADRANGLE.

Kings Mills, on top of stone of southwest abutment of iron bridge over Little Miami River, 3 feet from end of bridge truss and 0.3 foot below bridge floor; aluminum tablet stamped " 618 CINN".

Red Lion, 5 feet from northwest corner of M. E. Church, in north foundation wall, 1 foot above ground; aluminum tablet stamped " 962 CINN"..... . 



\section{N D E X .}

A.

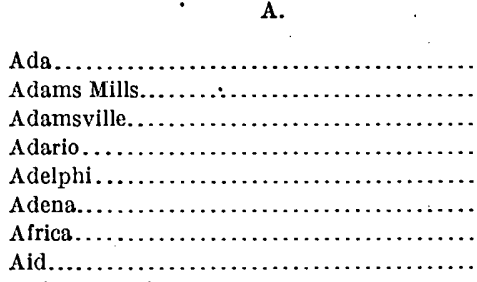

Page. 102

Airline Junction.

Akron. $23,24-25$

kron quadrangle.

Albany.

Alexandria 53,92

Alexis.

Alfred.

Alikanna.

Allentown.

Alliance.

Alliance quadrangle

Alma.

Alvada.

Amanda..................................

Amesville.

Amsterdam

Andover

Andover quadrangle.

Angel.

Ansonia

Antioch.

Antrim.

Antrim quadrangle.

Arabia...

Arcanum.

Arlington

Arlington quadrangle

Armitage.

Armstrong .

Armstrongs Mills

Ashland.

Ashland quadrangle.

Ashmont...

Ashtabula.

Ashtabula quadrangle.

Ashton.

Ashville.

Astoria.

Athalia quadrangle.

A thens....

Athens quadrangle.

Atwater Center.

Auburn Center.

Aukerman

Aultman

Aurora...

Austinburg.

Ava...

Avis.
B.

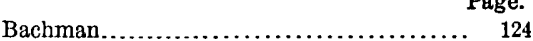

Bainbridge.......................... $\quad 29$

Bairds Furnace....................... 90

Baldwin, D. H., work of.................. 6

Baltimore........................... 18

Bannock.............................. 50

Bannon.............................. 17, 18

Barberton............................ 25

Barnesburg.......................... 133

Barnesville........................... 53

Barry ............................... 28

Bartlett............................ 59

Barton................................ 50

Bascom.............................. 95, 96

Basil............................... 18

Batesville............................ 70

Beallsville............................. 52

Beallsville triangulation station ........... 52

Beaumont............................ 58

Beaver.............................. 110

Beaverdam........................... 102

Beckett............................ 74

Bedford $\ldots \ldots \ldots \ldots \ldots \ldots \ldots \ldots \ldots \ldots \ldots, 9,23$

Beech Grove........................... 125

Belden............................ 41

Bellaire:................ 50

Belle Valley.............................. 72

Belle Vernon........................ 100

Bellevue. . . . . . . . .

Bellevue quadrangle................... 93,97

Bellpoint............................ 105

Belmont............................ 51

Belmore............................. 117

Beloit............................... 36

Bend ................................. 94

Bennetts Corner..........................

Benton Ridge....................... 116

Berea.............................. 24

Berea quadrangle...................... 23-24

Bergholz ............................. . 46

Berlin Center............................ 32

Berlin Heights...................... 97, 98

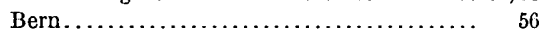

Bernice.......................... 80,81

Berysburg............................. 92

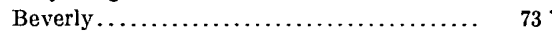

Bidwell quadrangle.................... 60

Big Plain............................ 111

Birds Run......................... 20, 79

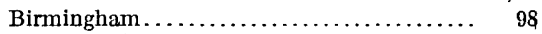

Black Run........................... 82

Blaine.............................. 50

Blanchester....................... 132

Blanchester quadrangle............... 131-132

Bloomdale........................... 96

Bloomfield..................... 48, 79,80

Bloomingburg........................ 122

Bloomville.......................... 101

Blue Bell............................ 134 


\begin{tabular}{|c|c|}
\hline luffton $. \ldots \ldots \ldots \ldots \ldots \ldots \ldots \ldots \ldots \ldots \ldots \ldots \ldots, 102$ & Canton.... \\
\hline luffton quadrangle.................... 101-102 & Canton quadrangle. \\
\hline$\ldots \ldots .33$ & Cardington quadrangle. \\
\hline 39 & 104 \\
\hline 40 & \\
\hline 23 & arpenter. \\
\hline tkins. . & rroll. . \\
\hline otzum.... & Carrollton \\
\hline owerston. . & arrollton \\
\hline owling Green... & 19 \\
\hline owling Green quadr & Cassville. \\
\hline$\ldots \ldots$. & Cedarville \\
\hline 69 & 105 \\
\hline 134 & ... $28-29$ \\
\hline ... 89,90 & \\
\hline 18 & \\
\hline 50 & \\
\hline .... & 21 \\
\hline ....... & $\ldots .21-22$ \\
\hline$: \ldots \ldots 42,111$ & $\ldots .31,109$ \\
\hline 47 & \\
\hline 71 & \\
\hline$\ldots .$. & 123 \\
\hline . . $27,28,29-30$ & 28 \\
\hline ...... 30 & \\
\hline 100 & 59,75 \\
\hline 33 & .. 57,59 \\
\hline .... 124-125 & \\
\hline …. 98 & 133 \\
\hline 55 & $\ldots \ldots \ldots 128,129$ \\
\hline 86 & .. $13,15,108$ \\
\hline ........ & $5-16,108-109$ \\
\hline ......... & ... \\
\hline$\ldots \ldots \ldots$ & \\
\hline ........... & \\
\hline$\ldots \ldots \ldots$ & \\
\hline ......... & $15,16,81,91$ \\
\hline -........ & … 21 \\
\hline ......... & 126 \\
\hline .......... & \\
\hline$\ldots \ldots \ldots$ & \\
\hline 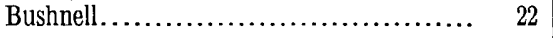 & 131,132 \\
\hline yersville................. & 66 \\
\hline & \\
\hline 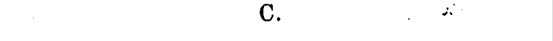 & 10 \\
\hline ..... & $.83,84$ \\
\hline 48 & 49 \\
\hline$\ldots 45,47-48$ & $8,9,23$ \\
\hline ..... & . . 8-9,23 \\
\hline & $\ldots \quad 133$ \\
\hline$\ldots 68,73-74$ & \\
\hline$\ldots \ldots \quad 133$ & \\
\hline$\ldots \ldots 34,35$ & 68,80 \\
\hline 66 & \\
\hline$\ldots 20,71,80$ & \\
\hline $20,68,79-80$ & \\
\hline$\ldots 130,131$ & $\varepsilon$ \\
\hline 52 & \\
\hline 6 & \\
\hline 13 & \\
\hline 39 & \\
\hline 59 & 22,2 \\
\hline$\ldots \ldots .37,39$ & \\
\hline 38 & 12 \\
\hline 107 & 2,9 \\
\hline & Collinsville $\ldots \ldots \ldots \ldots \ldots \ldots \ldots \ldots \ldots$ \\
\hline
\end{tabular}




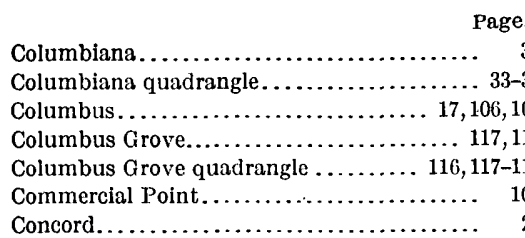

Concord................................ ${ }_{78,79}^{21}$

Conesville quadrangle............... $68,78-79$

Congo................................. 88

Conneaut............................ 22

Conneaut quadrangle................. 20,22-23

Continental........................... 115

Continental quadrangle....... 10-11,11-12,112,115

Conway .............................. 48

Cook............................... 122

Coolville............................... 65

Cooperdale........................... $\quad 82$

Copley................................. 25

Cordelia............................. 102

Cork.............................. 22

Cornersburg....................... $\quad 33$

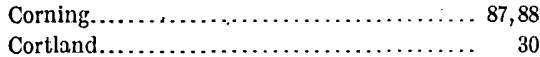

Coschocton.......................... 80

Coschocton quadrangle.................. 68,80

Cottage Hill.......................... 82

Covington quadrangle................ 124, 127

Cowlesville........................... 120

Cox................................ 109

Crabapple........................... 52

Craig................................... 80

Cranmer............................... 24

Crawford........................... 48, 104

Creola................................ 62

Crescentville.......................... 134

Cridersville........................... 119

Crooksville........................ 85,88,89

Croswell............................ $\quad 11$

Croton............................... 84

Crowley ............................ 16

Cuba............................... ${ }_{132}$

Cumberland ............................ 72

Cumberland quadrangle $\ldots \ldots \ldots \ldots, 17,19,68,71-72$

Curtice.............................. 93

Custar.............................. $\quad 113$

Cuyahoga Falls....................... 9,10

D.

Dale.

59

Dalton.... . . . . . . . . . . . . . . . . . . $\quad 38$

Damascus........................... $\quad 36$

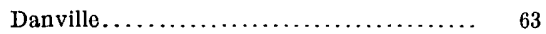

Darrtown..................... 130, 133, 134

Dawis................................ 14

$1 \quad$ Dawn............................... 127

Dayton............................ 120

Deep Hollow........................ $\quad 59$

Decrfield............................. 31, 37

Deersville.......................... 49

Deffenbaugh......................... 77

Defiance....................... 12,113, 114

Defiance quadrangle........... 10,12,112,113-114

Delano............................. 15, 108

Delaware........................ 105, 106

Delaware quadrangle................. 101,105-106

Delphos quadrangle................... 112,115
Page.

Dennison............................ $\quad 21$

Derby ............................ 107

Derthick............................ 58

Derwent............................. 71

Deshler.......................... 116,117

Deshler quadrangle................... 116-117

Dexter............................... 64

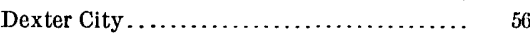

Dillon............................. 82,84

Dillonvale.......................... 50

Dixie............................. 89, 96

Dorninton.......................... 11

Dorset.............................. 28

Douglas, E. M., work of .................. 6

Drakes............................... 88

Dresden............................. 81

Dublin.............................. 104

Dublin quadrangle.................. 104-105

Dudley............................. $\quad 73$

Dumontville.......................... 87

Dunbar............................... 55

Dundas............................ 63

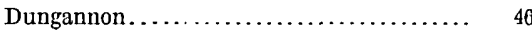

Dunkirk......................... 102

Durant............................ 76

Duvall.......................... 16,71,107

Dye............................... 54

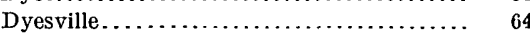

E.

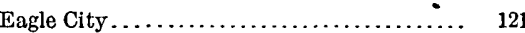

Eagleport.......................... 74,75

Eaglesville............................ 22

East Akron . . . . . . . . . . . . . . . . . . . . 10

East Akron Junction.................... 10

East Cincinnati quadrangle . . .............. 132, 133

East Claridon ........................... 21

East Columbus quadrangle............ 15,16-17,

$18,101,106-107$

East Greenwood . ....................... 78

East Liverpool .......................... 45

East Mandale......................... 11

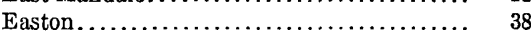

East Palestine....................... 34

East Salem........................ $\quad \mathbf{8 0}$

East Springfield ....................... 48

East Union........................... 39

Eaton............................... 126,130

Eaton quadrangle................ 129,130-131

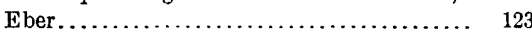

Edinburg............................ 31

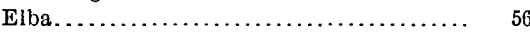

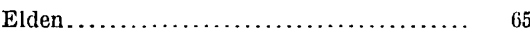

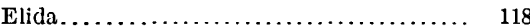

Elizabeth............................ 19

Elizabethtown........................ 68

Elk..................................... 57

Elkton............................. $\cdot 35$

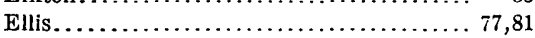

Ellsworth.......................... 32

Elmore quadrangle..................... 93,95

Elmwood............................. 10

Elroy.............................. 127

Emery Chapel. . . . . . . . . . . . . . . . . . . . . 121

Enfield............................. 48

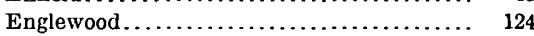

Enon ............................... 121 


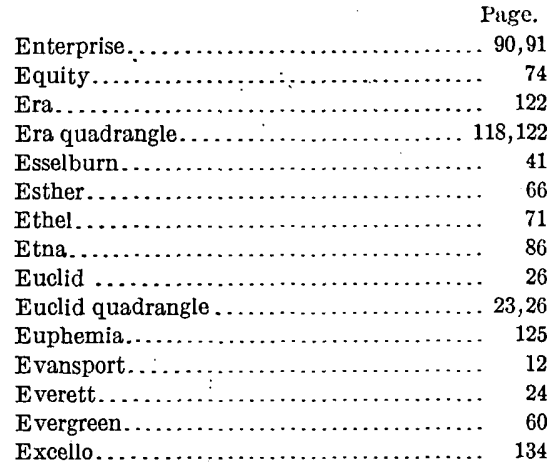

\section{F.}

Fairpoint

Fairview.

Fairview schoolhouse.

50

51,69

Farmerville.

Farnham

Fay.

Feightner.

Ferncliff.

Fernwood.

Fifteen

Findlay.

Findlay quadrangle.

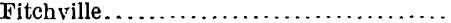

Flag...............................

Flaming. .............................

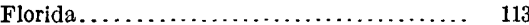

Flushing............................... 51

Flushing quadrangle................ 45,51-52

Folk................................ 48

Foraker Bridge...................... $\quad 53$

Ford ................................ 28

Forest......................... 102, 103

Fort Recovery...................... 128

Fort Seneca........................ 101

Foster............................. 134

Fostoria............................ 95

Fostoria quadrangle $\ldots \ldots \ldots \ldots \ldots \ldots \ldots, 93,95-96$

Fowlers Mill........................ 26,27

Franklin......................... 49, 78, 129

Franklin Square...................... 35

Frazeysburg.......................... $80-81$

Frazeysburg quadrangle............... 81

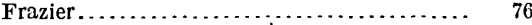

Fredericksdale........................ 71

Fredericktown quadrangle............... 84-85

Fredonia............................ 84

Freeburg............................. 37

Freedom.............................. 31

Freeland $\ldots \ldots \ldots \ldots \ldots \ldots \ldots \ldots \ldots \ldots, \quad 77$

Freeport........................... 69,70

Fremont........................... $\quad 97$

Fremont quadrangle.................... 93,97

Fryburg............................. 120

Frytown........................... 130

Fulda $\ldots \ldots \ldots \ldots \ldots \ldots \ldots \ldots \ldots \ldots \ldots \ldots \ldots \ldots \ldots, \quad 56$

Fuller $\ldots \ldots \ldots \ldots \ldots \ldots \ldots \ldots \ldots \ldots \ldots, \quad 49$

Fultonham........................... 19

Fulton triangulation station.............. 58

Furmandale
G.

Page.

Gallia............................... 66

Gallipolis............................ $\quad 60$

Galloway Knob....................... 51

Gallup.............................. 114

Gannett, S. S., work of................... 6

Garrettsville quadrangle................ 28, 29

Gates Mill.......................... 27

Gavers ....................... 46

Geneva.............................. 27

Genoa............................. 93

Germantown ......................... 129

Germany.......................... 110

Gettysburg......................... 125, 126

Geyer............................ 123

Gibson.............................. 70

Giddings............................ 23

Gilbert........................... $\quad 77$

Gilboa............................. 116

Gillespieville........................ 105

Gillivan............................ 111

Ginghamsburg....................... 120

Girard.............................. 33

Givens............................. 109

Glade.............................. 110

Glass rock.............................. 18, 86

Glencoe............................ 51

Glenford............................. 18

Glen Jean.......................... 14

Glenwood quadrangle................ 60,61

Glouster.............................. 88

Gnadenhutton ....................... 20

Goes............................. 121

Gordon............................ $\quad 125$

Gore............................... 90

Gould $\ldots \ldots \ldots \ldots \ldots \ldots \ldots \ldots \ldots \ldots \ldots, \quad 47$

Grafton.............................. 24

Grand Rapids........................ 12, 112

Granger.............................. $\quad 25$

Granville.............................. 83,84

Granville quadrangle................ 81, 83-84

Gratis.............................. 131

Grayson............................. 123

Graysville........................... 53

Greencamp.......................... 99

Greene.............................. 29

Greenfield............................. 66

Greenough $\ldots \ldots \ldots \ldots \ldots \ldots \ldots \ldots \ldots \ldots \ldots, 48$

Greenup quadrangle................... 65,67

Greenville............................ 126

Greenville quadrangle $\ldots \ldots \ldots \ldots \ldots \ldots, 124,126-127$

Gregory................................ 105

Griggs Corners......................... 23

Grosvenor............................ 58

Grove............................ ${ }^{107}$

Grover Hill.......................... 115

Guernsey.............................. 20,80

Guilford............................ $\quad 36$

Gutman............................. 119

Guysville.......................... 59

\section{H.}

Hales Creek......................... 66

Hallsville........................ 108, 109

Hamden $. . . \ldots \ldots \ldots \ldots \ldots \ldots \ldots \ldots \ldots \ldots . .6,65$

Hamilton. . ........................ 53, 133

Hamilton quadrangle. ............. 132, 133-134 


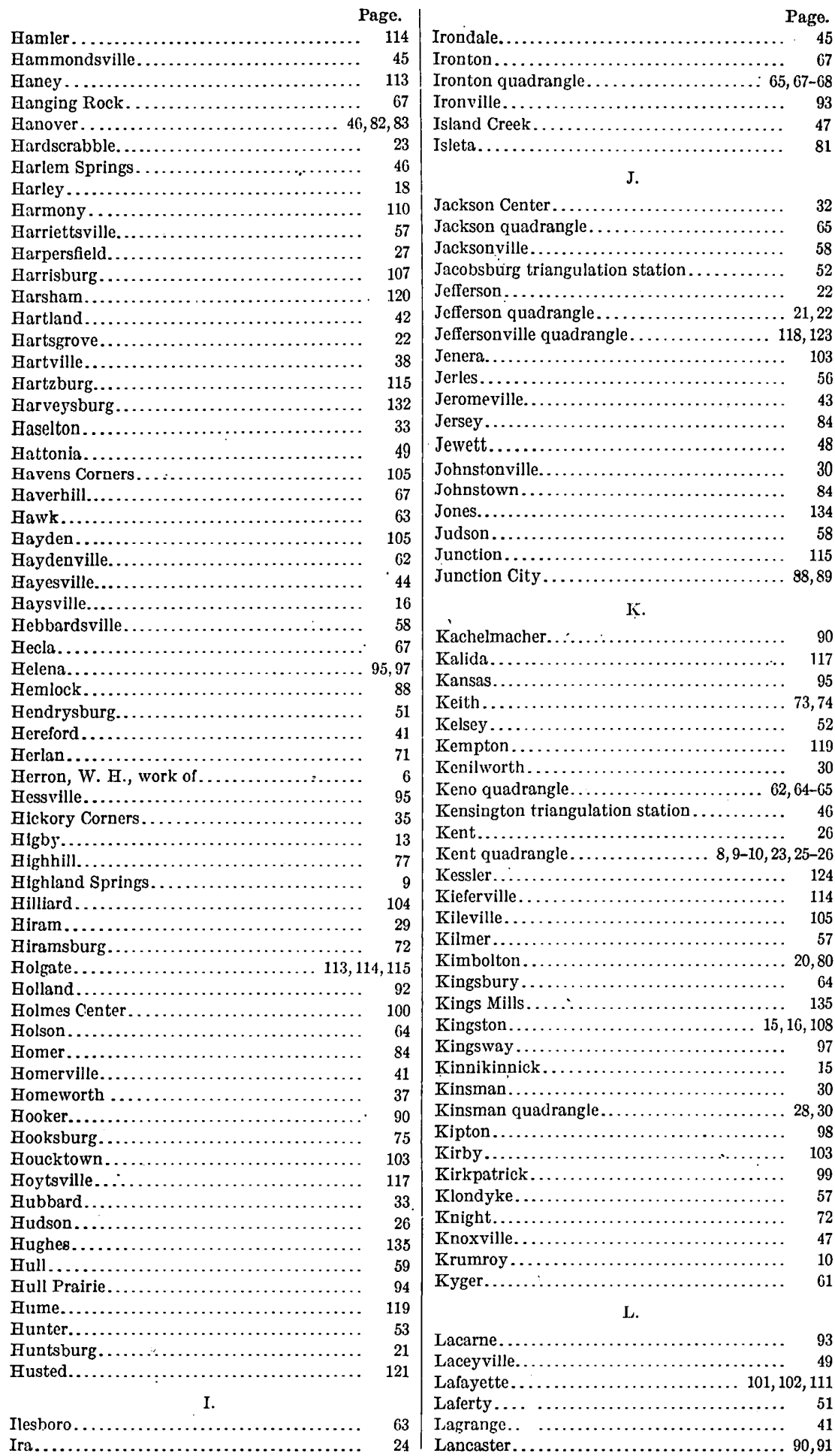


Pagre.

Lancaster quadrangle.

$81,90-91$

Landis............................. 126

Langsville.......................... 64

Laura. .............................. 124

Laurel ville quadrangle. . . . . . . . ........ 108,109

Lawrence. . . . . . . . . . . . . . . . . ...... 54

Law triangulation station $\ldots \ldots \ldots \ldots \ldots \ldots \ldots \quad 55$

Leaper.

Leavittsburg. ..................... 32

Lebanon quadrangle. . . . . . . . . . ........ 135

Leesvili.e. ......................... 49

Leipsic........................ 116

Lemert. . . . . . . . . . . . . .............. 100

Lenox. ........................ 22,28

Leonardsburg. ...................... 106

Lester ............................. 40

Lewisburg.......................... 125

Lewisville........................ 53

Liberty . . . . . . . . . . . . . . . . . ..... 130

Liberty Center....................... 12

Lima. . . . . . . . . . . . . . . . . . . . . 118, 119

Lima quadrangle. .................. 118-120

Lime City ........................ 92

Limerick......................... 110

Limestone........................ 48,93

Lintōn Mills.................... 79

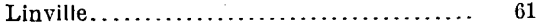

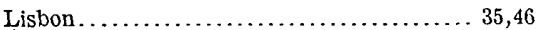

Lisbon quadrangle. . . . . . . . . . . . $33,35-36$

Litchfield........................... 41

Lithopolis........................ 107

Little Hocking.

Little York.

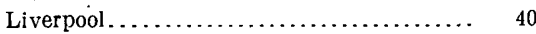

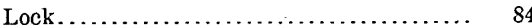

Lockbourne.................. 16,106

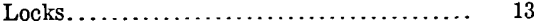

Locust Grove......................... 35

Lodi.............................. 41

Logan

Logan quadrangle

London quadrangle. ............. 110,111-112

Londonderry ........................ 69,108

Longley ......................... 95

Lorain. . . . . . . . . . . . . . . . . . . . . 24

Loramie quadrangle............... 124, 128-129

Lordstown . . . . . . . . . . . . . . . . . . 32

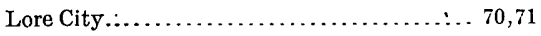

Louisville........................... 38

Loveland............................. 134

Lovell............................. 104

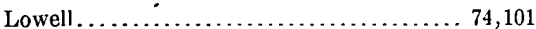

Lowellville......................... 33

Lower Salem. ..................... $5 \overline{7}$

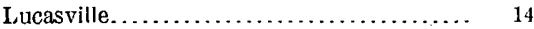

Luckey.......................... 94

Ludlow . . . . . . . . . . . . . . . . . . . . . . . 124

Luke Chute....................... 74

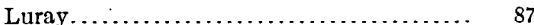

Lybrand . . . . . . . . . . . . . . . . . . . . 106

Lykens............................ 190

M.

Mabee.

Macabee Hill.

McArthur,
McClure.................... 10, 12,112

McClure quadrangle.................... 112-113

McComb......................... 116

McConnelsville .................. 75, 76,88

McConnelsville quadrang!e . . . . . . . . 68, 74-70

McCutcheonville........................ 104

Macedonia..........................

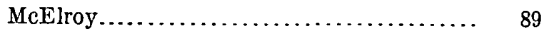

Macksburg....................... 56

Macksburg quadrangle.............. 54,55-57

McLuney........................... 89

Madison..................... 22, 27,66

Madisonburg ........................ 39

Madison Mills....................... 122

Madisonville......................... 133

Malaga . . . . . . . . . . . . . . . . . . .

Malinta............................ 113

Malta..........................

Mandale.......................... 11

Mansfield.............................. 44

Mansfield quadrangle................. 43,44

Mantua Center ........................ $\quad 29$

Marbletown . . . . . . . . . . . . . . .

Maria Stein........................ 129

Marietta......................... 54,55

Marietta quadrangle.................. 54

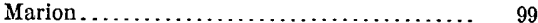

Marion quadrangle................... 98,99

Marlboro............................ 37

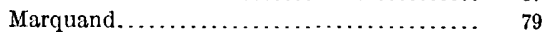

Marshall, R. J3., work of................ 6

Marshallville ....................... . 38

Marshfield.......................... 58

Martins Ferry ...................... 50

Martinsville........................ 132

Mason quadrangle................ 132, 134-135

Massillon ......................... 38

Massillon quadrangle................ 37,38

Maynard......................... 50

Mecca......................... 30

Mechanicsburg .................... 53

Medina............................. 40

Medina quadrangle................... 40

Medway............................. 120

Meigs....................... 74,76

Melrose......................... 11,115

Mentor............................ 26

Mentor quadrangle............... 23, 26-27

Mercerville.......................... 61

Merriam......................... 76

Mesopotamia........................ 29

Meyers............................. 97

Miami............................. 133

Miamisburg......................... 129

Miamisburg quadrangle. . . . . . . . . . . . . . 129-130

Miamiville........................ 133

Middle Bass Island . . . . . . . . . . . . . . $\quad 92$

Middle Branch................... $\quad 38$

Middlebourne...................... 69

Middle Creek.................... $\quad 57$

Middlefield......................... 29

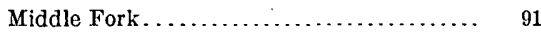

Middleport........................ 60

Middletown $\ldots \ldots \ldots \ldots \ldots \ldots \ldots \ldots \ldots \ldots \ldots \ldots, 34,129$

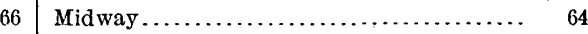

54 Midway triangulation station............. 80

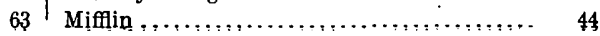


Page.
Milan

Milan

Miller City

Millersburg.

Millersport

Millersville.

Mill Rock.

Mill Run.

Mill school

Mills station

Millville.

Milnersville.

Miltonsburg

Miner.

Mincral.

Minerton.

Mingo Junction.

Misco.

Moffitt.

Mondovia.

Monnett.

Monroe Center.

Monroefield .

Monroeville.

Montezuma

Montville.

Moonville.

Mooresville.

Morgan Bridge.

Morgansville.

Morning Sun.

Morral.

Moultrie.

Mount Blanchard ....................

Mount Carmel.

Mount Cory

Mount Ephraim

Mount Perry

Mount Sterling..................... 122, 123

Mount Sterling quadrangle. .......... 118, 122-123

Mountville....................... 75

Moxahala......................... 87

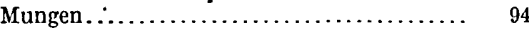

Munroe Falls.......................... 25

Myers Knob....................... 52

Myersville....................... 10

N.

Nankin:

Napier.

Napoleon.

Napoleon quadrangle.

Nashport.

Nashville.

Navarre quadrangle.

Neffs

Negley.

Nelson.

Nelsonville.

\section{Nevada.}

New Albany.

New Alexander.

New Alexandria.

Newark ...

Newark quadrangle.
New Baltimore.................. $\begin{gathered}\text { Page. } \\ 38,134\end{gathered}$

New Bavaria...................... 115

Newberg. . . . . . . . . . . . . . . . . . .

New Berlin . . . . . . . . . . . . . . 10

New Bremen....................... 128

New California........................ 104

New Carlisle. . . . . . . . . . . . . . . . . . . . 120

New Chambersburg................... 37

New Comerstown ................. 20,81

New Comerstown quadrangle. ...... 17, 20, 68,81

New Concord.................... 19, 72,80

New Cumberland ................... 39

New Garden........................ $\quad 36$

New Harrison $. . \ldots \ldots \ldots \ldots \ldots \ldots \ldots \ldots . . . \ldots \ldots$

New Holland.......................... 122

Newhope....................... 126

New Knoxville....................... 128

New Lebanon. ........................ 124, 130

New Lexington . .................. 87, 125

New Lexington quadrangle........... 81,87,89

New London......................... 41,42

New London quadrangle............. 40,41-42

New Madison. . . . . . . . . . ........... 125

New Martinsville quadrangle............ 52,54

New Matamoras..................... 54

New Matamoras quadrangle........... 52,53-54

New Middletown.................... 34

New Moorefield. . ..................... 111

New Pittsburg. ..................... 43

New Plymouth. .................. 62

Newport. ...................... $\quad 111$

New Riegal. ...................... 90

New Rochester....................... 94

New Salem..................... 18,86

New Somerset..................... 45

New Springfield....................... 34

Newton Falls...................... 32

New Waterford .................... 34

New Weston. .................. 127, 128

Niles. ......................... 32,33

Nimisila $\ldots \ldots \ldots \ldots \ldots \ldots \ldots \ldots \ldots \ldots \ldots \ldots \ldots \ldots$

Ninemile....................... 133

North Baltimore..................... 96

North Bass Island....................

North Bloomfield . . . . . . . . . . . . . . . . . . $\quad 29$

North Creek....................... 115

North Hampton................... 122

North Kingsville....................... ${ }_{22}$

North Madison........................ 27

North Nefis...................... 51

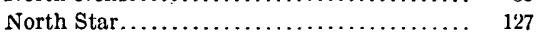

North Washington................. 102

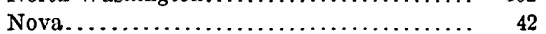

O.

Oak Grove....................... 100

Oak Harbor....................... 93

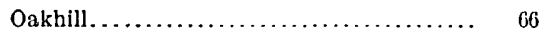

Oakhill quadrangle................ 65, 66

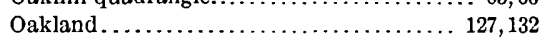

Oakwood ........................... 12

Oberlin . . . . . . . . . . . . . . . . . . . 24

Oberlin quadrangle................. 23, 24

O'Betz.............................. 18

Odell. . . . . . $\ldots \ldots \ldots \ldots \ldots \ldots \ldots \ldots \ldots \ldots, 68,69$

Ogden............................. 131

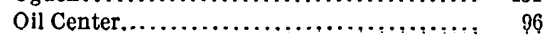




\begin{tabular}{|c|c|}
\hline Page & age. \\
\hline 113 & \\
\hline 101 & Pomeroy qua \\
\hline livesburg. & Por \\
\hline$\ldots 14,110$ & 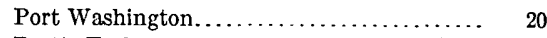 \\
\hline 54 & ratts Fork. \\
\hline 102 & 63 \\
\hline 58 & 11 \\
\hline 63 & rentiss... \\
\hline le.... & $\mathrm{n}$. \\
\hline 22 & 106 \\
\hline 120 & 97 \\
\hline $\operatorname{rg} \ldots \ldots \ldots \ldots$ & 29 \\
\hline 79 & 83 \\
\hline Ottawa..... & 92 \\
\hline $10-11,112,114-115$ & 92 \\
\hline uadrangle... & \\
\hline .. 86 & 124 \\
\hline Owens...... & \\
\hline xford....... & \\
\hline & Quaker City. \\
\hline$\ldots 21,27$ & \\
\hline$\ldots \ldots \ldots \ldots \ldots \quad 126$ & Radnor \\
\hline ....... & lph.... \\
\hline$\cdots \cdots$ & . \\
\hline 122 & ze Island... \\
\hline 102 & $\ldots 26,32$ \\
\hline 37 & $\ldots .31-32$ \\
\hline$\ldots \ldots \ldots \ldots, 54,55$ & … 102 \\
\hline .......... 29 & .. 134,135 \\
\hline 105 & $\cdots$ \\
\hline 24 & $\cdots$ \\
\hline$\ldots \ldots \ldots \ldots .84,86$ & $\ldots$ \\
\hline 35 & $\ldots 85,87$ \\
\hline 115 & ... 87,88 \\
\hline 44 & $\cdots$ \\
\hline$\ldots \ldots$ & $\ldots 72,73$ \\
\hline ............. & J. H., work of .... \\
\hline$\ldots \ldots \ldots \ldots 24,25$ & - \\
\hline drangle. . . . . . . . . . . . . 23, 27 & $\therefore$ \\
\hline$\ldots \ldots \ldots \ldots \ldots \ldots \ldots \ldots \ldots \ldots \ldots \ldots \ldots \ldots$ & $\operatorname{urg} . . .$. \\
\hline n............ & Corn \\
\hline quadrangle....... & 25 \\
\hline (34 & $\therefore \cdots$ \\
\hline ............. & $\ldots \ldots \ldots$ \\
\hline$\ldots \ldots \ldots \ldots$ & $\ldots .101,100$ \\
\hline$\ldots 17,19,68,76-77$ & Corners........................ \\
\hline$\ldots \ldots \ldots \ldots \ldots \ldots \ldots \ldots \ldots \ldots \ldots \ldots \ldots \ldots \ldots \ldots$ & $\ldots \ldots \ldots \ldots \ldots \ldots \ldots \ldots \ldots \ldots \ldots \ldots \ldots \ldots \ldots, 117,118$ \\
\hline on $\ldots \ldots \ldots \ldots \ldots \ldots \ldots \ldots \ldots \ldots \ldots \ldots \ldots$ & ( \\
\hline (n............. & 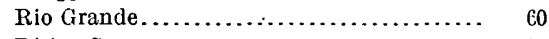 \\
\hline$\ldots \ldots \ldots \ldots \ldots \ldots \ldots \ldots \ldots \ldots \ldots \ldots \ldots \ldots \ldots \ldots, 23,28$ & ......... \\
\hline ......... 109 & \\
\hline ( n............ & ....... \\
\hline le $\ldots \ldots \ldots \ldots \ldots \ldots \ldots .13,14$ & .... 109,110 \\
\hline ....... & 42 \\
\hline$\ldots \ldots \ldots \ldots \ldots \ldots 110,121$ & \\
\hline$\ldots \therefore$ & 67 \\
\hline -.. & 100 \\
\hline$\cdots \cdots$ & s. \\
\hline ......... & 93 \\
\hline end. & 24 \\
\hline ..... & \\
\hline$\ldots \ldots \ldots \ldots \ldots$. & \\
\hline$\ldots \ldots \ldots \ldots \ldots \ldots, 87,90$ & 127 \\
\hline ....6.60-61 & 11 \\
\hline 3 & 85 \\
\hline 43 & 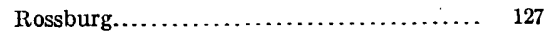 \\
\hline
\end{tabular}




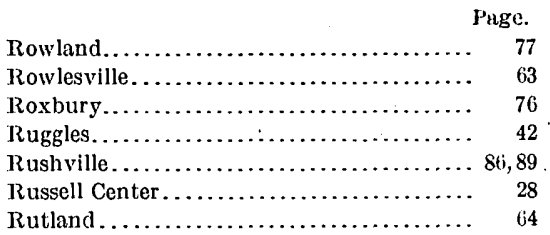

s.

St. Charles ...

St. Clairsville

St. Clairsville quadrangle.

St. Henry.

St. Henry quadrangle

St. Louisville.

Salem.

Salesville.

Salineville quadrangle.

Sand Hill.

Sandusky...

Sandusky quadrangle.

Sarahsville.

Sargents.

Savannah

Savona.

Saybrook.

Sayre.

Schooley.

Scio quadrangle.

Scioto.

Scioto quadrangle.

Sciotoville.

Scottown....

Scroggsfield.

Seasons.

Sedaliā.

Sego.

Selkirk.

Senecaville.

Sevenmile.

Seville. . .

Shadeville.

Shalersville.

Shandón.

Sharon Center.

Sharonville.

Shawnee.

Shawnee Junction

Shawtown

Sherman

Sherman Corners .

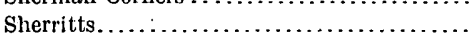

Sherrodsville...........................

Shilling....

Shinrock..............................

Shunk. .

Signal.

Silver Lake.

Silver Lake Junction

Silverton.

Simms.

Skelley.....

Smithdale.

Smithfield ....

$$
\text { S }
$$

Page.

Sinithville ......................... $\quad 39$

Snodes............................. $\quad 35$

Solon ................................ 28

Somerdale ............................ 39

Somerset............................. 86

Somerville.......................... $\quad 1.30$

Sonora............................... 19,78

South Charleston....................... 111

South Charleston quadrangle............ 110-111

South Columbus....................... 107

South Euclid........................... 26

Southington......................... $\quad 30$

South New Lyme ...................... 22

South Olive............................ 56,73

South Solon.......................... 123

South Thompson........................ 21

South Warsaw ...................... $\quad 119$

South' Zanesville...................... 19,85

Spanker............................. 120

Spiller............................... 64

Spratt................................ 72

Springdale......................... 9

Springfield............................. 121

Springfield quadrangle............... 118, 121-122

Stafford................................ 56

Starr.................................. 62

Station Fifteen.......................... 49

Sterling.............................. 39

Steubenville:........................ . 47

Steubenville quadrangle............... 45,47

Stillwater Junction...................... 125

Stockdale.............................. 67

Stockport.........................., 75

Stockton........................... 134

Streetsboro........................... 26

Stringtown ............................. 91

Stryker........................... 114

Sugar Grove............................... .

Sugar Island ........................ 92

Sugar Ridge ........................., 94

Sullivan.............................. 41,43

Summerfield ............................ 70

Summerfield quadrangle................ $68,70-71$

Summerford .......................... 111

Sunbury ................................ 105

Sundale............................ 19

Sutton, Frank, work of.................. 6

Swanktown........................ 124

Swanton quadrangle................... 112

Switzer............................... 52

Sycamore quadrangle................ 98, 100

Sylvania.............................. 92

Syracuse...........................

'T.

Tadmor................................ 121

Taylorsburg.......................... 120

Teegarden .......................... 35

Temperanceville......................... 53

Tennett tunnel....................... 70

Thompson............................... 22

Thornport........................... 18

Thornville .......................... 86

Thornville quadrangle............. 17, 18,81,86

49 Thurman.............................. 60

48,49 Thurston.......................... 18,87 


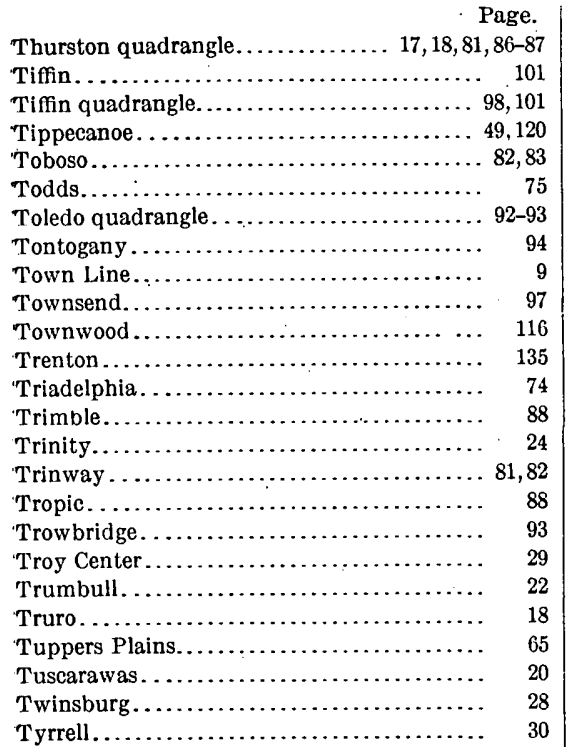

U.

Uhrichsville

20,21

Uhrichsville quadrangle. $17,20-21,45,49$

Union. 84,87

Union Furnace........................ 62

Unionport.......................... 48

Unionvale........................... 48

Unionville........................... 27

Uniopolis.......................... 119

Unity.............................. 34

Upper Sandusky .................... 103,104

Upper Sandusky quadrangle......... 101,103-104 Urbancrest............................. 107

Utica............................... 83

V.

Valley Crossing

16,17

Van Valley....

Vaughnsville...

Vera................................. 14

Vermilion $. . \ldots \ldots \ldots \ldots \ldots \ldots \ldots \ldots \ldots \ldots, \quad 98$

Vernon................................ 30

Versailles............................. 127

vickery............................. 97

Victoria............................. 128

Vienna.............................. 33

Vienna Crossroads....................... 111

Vigo ............................... 110

Villa.

W.

Wadsworth

Wakatomika.

Wakefield

Wakeman.

Walbridge.

- Waldo.

Waller.

Walser...

Wapakoneta.
Warner. . . . . P........................ $\quad 56$

Warren............................. 32

Warren quadrangle..................... 31,32

Warnock ............................ 51

Warrensville.......................... 23

Washington........................... 68

Washington Court House.................. 122

Waterford ............................. 74

Waterloo............................ 62,122

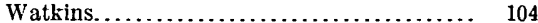

Waverly ............................ 14, 109

Waverly quadrangle.......... 13-14, 108, 109-110

Wayland.............................. 31

Webb Summit...................... 90

Weegee Creek Bridge...................... 52

Weilersville.......................... 39

Welian............................. $\quad 86$

Wellington ............................. 41

Wellington quadrangle.................40, 41

Wellston ............................... 65

Wellsville.............................. 45

Wellsville quadrangle. .................... 45

Wesley Chapel . ........................ 119

West A ustintown....................... 32

West Baltimore........................ 124

Westboro........................... 132

West Cairo ........................... 118

West Carlisle........................... 82

West Charleston...................... 120

Westchester............................. 135

West Cincinnati quadrangle............ 132, 133

West Columbus quadrangle............. 106, 107

Westerville............................ 105

Westerville quadrangle................ 101, 105

West Farmington . ...................... 29

Westhope........................... 113

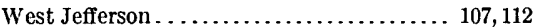

West Lafayette....................... 79,81

West Leipsic ........................... 114

West Manchester...................... 125

West Manchester quadrangle. . . . . . . 124, 125-126

West Mecca........................... 29

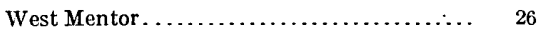

West Millgrove....................... 94

West Richfield.......................... $\quad 25$

West Salem........................ 43

West Salem quacirangle................., 43

Westville.............................. $\quad 36$

Weymouth.............................

Wharton.............................. 104

Wheelersburg......................... 67

Wheeling............................ $\quad 49$

Wheeling Creek ........................ 50

Wheeling quadrangle................ 45,49-50

Whigville............................ 71

Whipple............................ 55

Whisler............................... 108

White Cottage ...................... 19

Whitehouse $\ldots \ldots \ldots \ldots \ldots \ldots \ldots \ldots \ldots \ldots, 112$

Wick ............................... 28

Wickliffe........................... 26

Wilgus...............................

Wilkesville quadrangle............... $62,63-64$

Williamsfield.......................... 28, 30

Williamstown...................... 103.

Willow Island........................... 54 
INDEX.

Page.

Wilmington...................... 131, 132

Wills Creek

$\begin{array}{r}78 \\ \hline\end{array}$

Wilson, H. M., work of.

6

Winchester quadrangle

24,127

Windfall

Windsor

40
22,44

Wingston.

Winklers Mill

94

Winterset.

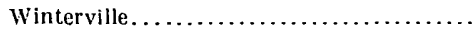

Winton Place.

54

Wisterman...

Wondington.

Woodland.

Woodsfield

Woodsfield quadrangle

Woodside.

Woodville.

Woodyards.

Wooster quadrangle.

Wooster University

Worthington.

Wrightstown...
Wyandot.....

Puge.

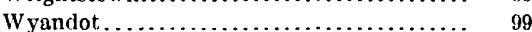

Wyoga..................... 9

Yankeetown................... 122, 125

Yatesville......................... 123

Yellow Springs....................... 121

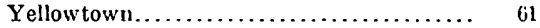

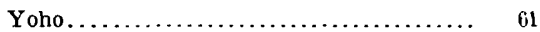

Yorkshire.................. 128, 129

Young Hickory . . . . . . . . . . . . . . . 72

Youngstown ...................... 33

Youngstown quadrangle............. 31,33

Yost.............................. 18

$-53$

Zanesville. . . . . . . . . . . $\ldots \ldots \ldots \ldots, 76,77,85$

Zanesville quadrangle.............. 17, 18-19

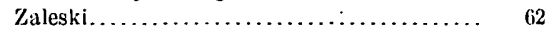

Zaleski quadrangle. ................62-(i3

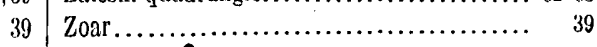

